Szegedi Tudományegyetem

Természettudományi és Informatikai Kar

Földtudományok Doktori Iskola

Gazdaság- és Társadalomföldrajz Tanszék

\title{
A TELEMEDICINA NÉHÁNY FÖLDRAJZI VONATKOZÁSA MAGYARORSZÁG PÉLDÁJÁN
}

\author{
Doktori (Ph.D.) értekezés
}

Bán Attila

Témavezető

Dr. Pál Viktor

egyetemi docens

Szeged 


\section{TARTALOMJEGYZÉK}

BEVEZETÉS 4

1. A KUTATÁS FÖBB KÉRDÉSEI, CÉLJAI, ALKALMAZOTT MÓDSZEREI.........6

1.1. A kutatás indokoltsága és problémafelvetése: a telemedicina felértékelődésének

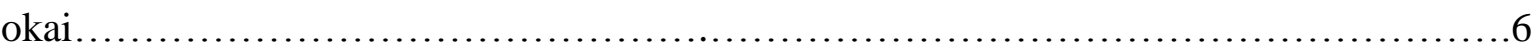

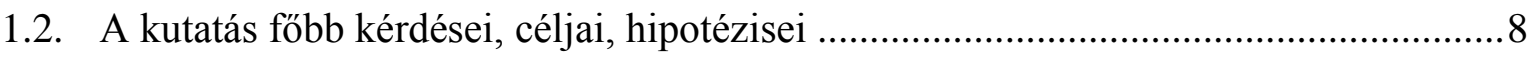

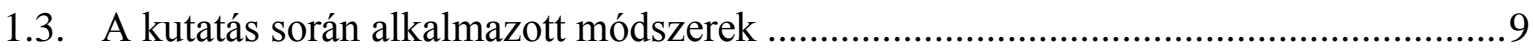

1.3.1. Az online kérdöives adatfelvétel módszertani alapjai és nehézségei ...................10

1.3.2. A félig strukturált interjúk módszertani alapjai és nehézségei ........................... 12

1.3.3. A családorvosi kérdöíves adatfelvétel módszertani jellemzöi ............................. 15

1.3.4. A kutatás során alkalmazott tartalomelemzés módszertani jellemzöi .................15

\section{A TELEMEDICINA ÁLTALÁNOS KÉRDÉSEI ÉS KAPCSOLATA A}

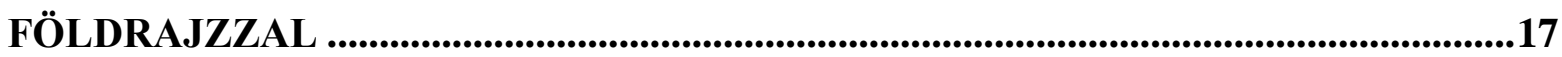

2.1. A telemedicina fogalmi kérdései: terminológiai alapok és részterületek ...................17

2.2. A telemedicina rövid története a 18-19. század fordulójától napjainkig ....................19

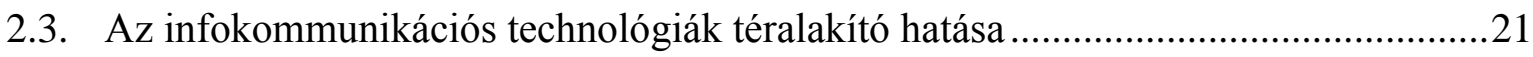

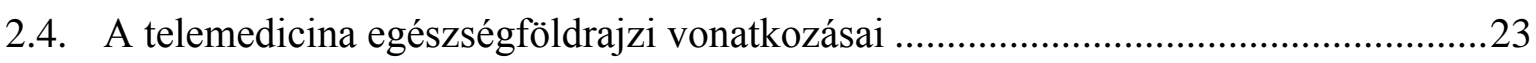

3. A TELEMEDICINA ÉS AZ EGÉSZSÉGÜGYI EGYENLŐTLENSÉGEK..............25

3.1. A hazai egészségügyi egyenlőtlenségek általános területi folyamatai ......................25

3.2. A telemedicina néhány egészségügyi egyenlőtlenséget csökkentő hatása .................29

3.3. A telemedicina hátrányai és összefüggései az egészségügyi egyenlőtlenséggel .........31

3.4. A telemedicina akadályozó tényezői globális léptékben ..........................................35

3.5. A vidéki területek egészségügyi ellátási problémái és a telemedicina .......................39

3.6. Az idős emberek telemedicinával kapcsolatos attitüdjei ..........................................40

3.7. Néhány szakirodalmi javaslat a telemedicinális akadályok lebontására ...................41

\section{A TELEMEDICINA ADAPTÁLÁSÁT ÉS ALKALMAZÁSÁNAK TERJEDÉSÉT} MAGYARÁZÓ FONTOSABB ELMÉLETEK........................................................................43

4.1. Az innováció terjedésének elmélete ........................................................................43

4.2. A technológia elfogadásának elmélete ..............................................................45

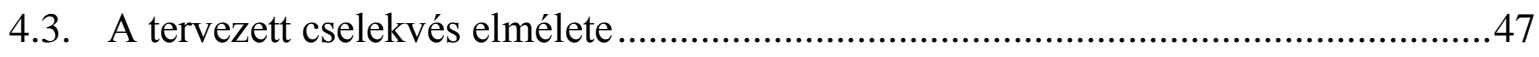

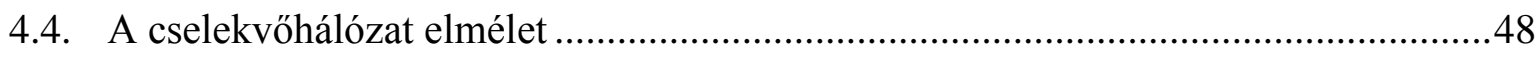

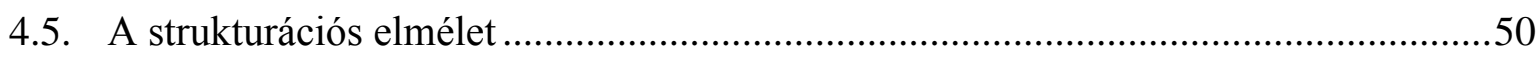

5. A KUTATÁS EREDMÉNYEI: A TELEMEDICINA ÉS AZ EGÉSZSÉGÜGY NÉHÁNY TÉRBELI-TÁRSADALMI KÉRDÉSEI MAGYARORSZÁGON ...............53

5.1. A telemedicinát alkalmazó egészségügyi szolgáltatók néhány egészségföldrajzi aspektusa egy kérdőíves felmérés alapján..... 
5.2. A telemedicinával kapcsolatos attitüdök és jövőbeli elképzelések az interjúpartnerek

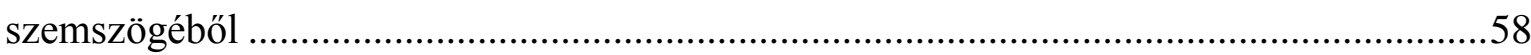

5.3. A telemedicina térre és távolságra gyakorolt hatásai ...........................................63

5.4. A telemedicina hatékonysági kérdései................................................................66

5.5. A telemedicina alkalmazását és terjedését gátló, illetve adaptálását segítő tényezők 71

5.6. A telemedicina egészségügyi egyenlőtlenségekre gyakorolt hatásai .76

5.7. A telemedicina orvos-beteg kapcsolatra és az egészségügyi szakemberek közötti viszonyra gyakorolt hatásai .80

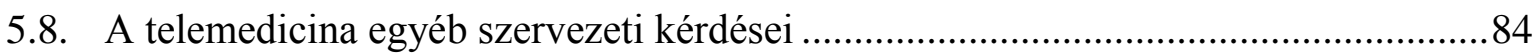

5.9. Az e-egészségügyi szolgáltatások és a távoli egészségügyi közösségek .87

5.9.1. A telemedicina esetleges hatásai a távoli egészségügyi közösségekre egy egészségportál példáján keresztül ............................................................................8

5.9.2. A telemedicina távoli egészségügyi közösségekre gyakorolt hatásai az interjúpartnerek álláspontja alapján.........................................................................92

5.10. A családorvosok néhány, telemedicinával kapcsolatos attitüdje ..............................96

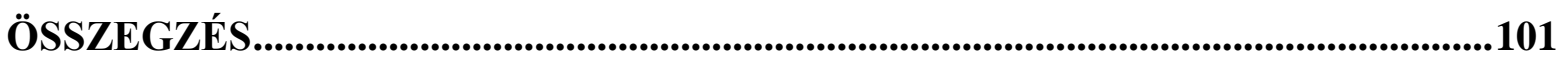

SUMMARY .....................................................................................................................................106

IRODALOMJEGYZÉK ........................................................................................110

FELHASZNÁLT FORRÁSOK........................................................................................118

KÖSZÖNETNYILVÁNÍTÁS........................................................................................119

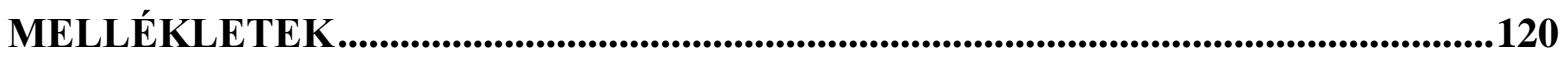




\section{Bevezetés}

Az infokommunikációs technológiák elmúlt évtizedekhez köthető robbanásszerü fejlődésének köszönhetően számos új, elsősorban internet alapú szolgáltatások (pl. internetbank) jelentek és jelennek meg, amelyek megkönnyítik a mindennapi társadalmi cselekvést és hatékonyabbá teszik a gazdaság müködését (JAKOBI Á. 2007, MARS, M. SCOTT, R.E. 2010, ScOTT, R.E. 2009). Ezek közé sorolható a telemedicina (távgyógyászat) is, ami e technológiák és az egészségügyi ellátás sajátos integrációjaként fogható fel, és lényegében az infokommunikációs technológiák egészségügyi ellátásban történő intenzív felhasználását jelenti (StARren, J.B. - NesBitT, T.S. - ChIANG, M.F. 2014, WHO 2010, 2011).

Napjainkban ez az innovatív szolgáltatás egyre inkább a figyelem középpontjába kerül mind az egészségügyi ellátórendszerben, mind az egészségpolitikában, és mindezen túlmenően a médiát is foglalkoztatja. Ennek okai abban keresendők, hogy - többek szerint - a telemedicina képes javítani az egészségügyi ellátás elérhetőségét, minél szélesebb körü hozzáférhetőségét és költséghatékonyságát (WoOTTON, R. 1999, 2009). E kedvező hatásai visszavezethetők a fizikai távolság gyors leküzdésére az információáramlás szempontjából, illetve a térbeli akadályok mérséklésére, ami erősíti a telemedicina földrajzi aspektusait az orvosi és informatikai vonatkozásai mellett.

Így a telemedicina térbeli vonatkozásai mindenekelőtt abban nyilvánulnak meg, hogy az egészségügyi centrumoktól távoli térségek számára is biztosítja a megfelelő ellátást jelentős távolság megtétele nélkül (FICZERE A. 2010a). Noha a földrajzi távolság továbbra is megmarad az ellátást nyújtó és az ellátásban részesülő között, de az ellátás elérhetősége javul, annak igénybevételéhez szükséges idő jelentős redukálásával. E hatás pedig arra vezethető vissza, hogy a telemedicinális ellátás során csupán az egészségügyi adatok és információk áramlanak a térben és nem az egészségügy szereplői mozognak. A telemedicina tehát bizonyos helyzetekben képes az egészségügyi szakemberek és páciensek térbeli mozgását helyettesíteni (WootTon, R. - BAHAAdinBeigy, K. - HAILEY, D. 2011).

A szakirodalom szerint a problémát az jelenti, hogy az előzőek ellenére a telemedicina térbeli - és ehhez szorosan kapcsolódva társadalmi - szempontjaira kisebb figyelmet fordítanak a kutatók (NICOLINI, D. 2006, 2007). Ráadásul nem áll rendelkezésre olyan térbeli adatbázis sem, ami keretbe foglalná a hazai telemedicinális projektekben és szolgáltatásokban érintett egészségügyi intézményeket. Noha tudomásom szerint teljes körü adatbázis külföldön sem létezik.

Ebből adódóan a kutatás során arra a fó kérdésre keresem a választ, hogyan befolyásolja a telemedicina az egészségügyet érintő térbeli-társadalmi folyamatokat? Ezen belül számos részkérdésre is választ kívánok adni. Többek között érintve a telemedicina térre és távolságra, az egészségügyi egyenlőtlenségekre, az egészségügyi közösségekre, az orvos-beteg és egészségügyi szakemberek közötti kapcsolatra és egyéb egészségügyi szervezeti kérdésekre gyakorolt hatásait. Az eddigieken felül vizsgálom a telemedicina hatékonysági vonatkozásait, a terjedését gátló tényezőket és ezzel az innovatív ellátási formával kapcsolatos attitüdöket.

Az előzőeknek megfelelően a kutatás fó célja a telemedicina területiségének és az egészségügyi ellátásra gyakorolt hatásának a vizsgálata a társadalmi aspektusok 
figyelembevételével. További célként jelenik meg a telemedicina iránti tudományos érdeklődés fokozása.

E kérdések és célok megválaszolásának első lépése a vonatkozó szakirodalom feltárása és áttekintése volt. A kutatás kezdetén elsőként a magyar nyelvű, egészségügyi szakfolyóiratok (pl. Interdiszciplináris Magyar Egészségügy (IME), Kórház, Lege Artis Medicinae (LAM), Orvosi Hetilap) témával kapcsolatos publikációinak feldolgozására tettem kísérletet. A telemedicina hazai szakirodalmának megismerésén túl, a nemzetközi publikációk identifikálását is relevánsnak tartottam. Mindenekelőtt egészségügyi, illetve szociológiai folyóiratok (pl. Social Science and Medicine) elemzésével foglalkoztam. Ezenfelül két, különösen telemedicina-orientált nemzetközi folyóirat, a Journal of Telemedicine and Telecare, illetve a Telemedicine and e-Health publikációit dolgoztam fel. Ezek megismerése hozzájárult a kutatás alapkoncepciójának, céljának és főbb kérdéseinek meghatározásához.

A szakirodalom feldolgozását követöen - a korábban már jelzett területi adatbázis hiányában - elsőként szükséges volt egy online kérdőíves adatfelvétel, amelynek eredménye a kutatás további módszertani lépéseit is meghatározta. Ez abban nyilvánult meg, hogy a kérdőív eredményeként kapott adatbázis alapjául szolgált egy kvalitatív vizsgálatnak, ami a kutatás kérdéseinek megválaszolásához szükséges volt. E lépés során félig strukturált interjúkat készítettem a telemedicina hazai helyzetére rálátó prominens szereplökkel (szakorvosokkal, háziorvosokkal, informatikusokkal, egészségügyi felsővezetőkkel). Ennek kiegészítéseként pedig további - családorvosok körében végzett - kérdőíves adatfelvételre, illetve egy egészségportál tartalomelemzésére került sor, amit a dolgozat módszertani fejezetében részletezek.

A disszertáció öt nagy egységre tagolódik. A dolgozat elején a kutatás indokoltságának, kérdéseinek, céljainak és módszertani jellemzőinek bemutatását követően a telemedicina terminológiai alapjait és térbeli kapcsolódását ismertetem. Ebben kitérek a távgyógyászat diskurzív jellegére, részterületeire, múltbéli fejlődésének főbb állomásaira és földrajzi vonatkozásaira. Ezt követően a telemedicina és az egészségügyi egyenlötlenségek kapcsolatát elemzem a hazai és nemzetközi szakirodalom alapján. E fejezeten belül felvázolom azokat a tényezőket is, amelyek gátolják a telemedicina bevezetését és alkalmazását az egészségügyi ellátásban, különböző földrajzi léptékekben. Végül az elméleti keret lezárásaként azokat a teóriákat tekintem át ( $\mathrm{pl}$. technológia elfogadásának elmélete, tervezett cselekvés elmélete stb.), amelyek elsősorban az egyén léptékében tesznek kísérletet a telemedicina adaptálásának magyarázatára. Különösen arra kívánok fókuszálni, hogy milyen tényezők determinálják a potenciális felhasználó szándékát a távgyógyászat használatára.

A disszertáció utolsó fejezetében az elméleti vonatkozásokhoz kapcsolódó empirikus kutatásaim eredményeit közlöm. Elsőként a telemedicinát alkalmazó egészségügyi szolgáltatók egészségföldrajzi aspektusait elemzem, majd az érintett prominens szereplők véleményét vizsgálom. Ezt követően a telemedicina távoli egészségügyi közösségekre gyakorolt hatásait taglalom, végül pedig néhány családorvos e szolgáltatással kapcsolatos attitüdjét ismertetem. 


\section{A kutatás főbb kérdései, céljai, alkalmazott módszerei}

\subsection{A kutatás indokoltsága és problémafelvetése: a telemedicina felértékelődésének okai}

Tekintettel a telemedicina interdiszciplináris jellegére (lásd orvostudomány, informatika stb.) több aspektusból is megragadhatók azok a tényezők, amelyek hozzájárulnak a felértékelödéséhez. Sajátosságuk, hogy ezek nem különülnek el élesen, sokkal inkább egymást kiegészítik.

Az egészségügy helyzetét érintve, ahhoz kapcsolódva az információs és kommunikációs technológiák (IKT) megjelenése jelenti az indokoltság egyik szálát. A telemedicina létrejötte és az ellátórendszerbe való integrálása ugyanis e technológiákhoz köthető (MURRAY, E. et al. 2011, WHO 2010).

Az elmúlt évtizedek egyik sajátos folyamataként számon tartott információtechnológiai forradalomnak és hatásainak - vagyis e technológiák megjelenésének, széleskörü elterjedésének és olcsóbbá válásának - köszönhetően az IKT kedvező tulajdonságai az egészségügyben is érvényesülhetnek (DICKEN, P. 2011, HARVEY, D. 1989).

Ezek az egészségügyi ellátás kedvezőbb elérhetőségét és méltányosabb hozzáférhetőségét segítik elő (FICZERE A. 2010a, 2010b, 2012b, 2012c, FiCZERE A. - KÖDMÖN J. 2011). A telemedicina felértékelődését pedig az egészségügyi ellátórendszer több évtized óta tapasztalható krízise adja, amit elsősorban a különböző egészségügyi erőforrások hiánya, és a megnövekedett egészségügyi szükségletek okoznak. Többek között az ágazatot érintő alulfinanszírozottság, és ehhez szorosan kapcsolódva a kvalifikált humánerőforrás (orvosok, ápolók) hiánya, az infrastrukturális és amortizációs problémák (különböző müszerek, berendezések hiánya és folyamatos drágulása, épületek fenntartása stb.), illetve az egészségi állapotban jelenlévő egyenlőtlenségek. Ezt a helyzetet tovább rontja a születéskor várható átlagos élettartam növekedésével a demográfiai „nyomás” is, ami még inkább elmélyíti ezeket a problémákat, hiszen az öregedéssel párhuzamosan nő az egészségügyi ellátás iránti igény. Az eddigieknek köszönhetően egyre inkább nyílik a szakadék az orvosilag elképzelhető és gazdaságilag realizálható ellátás között (CSÁKY A. et al. 2001, MURRAY, E. et al. 2011, OrOSZ É. 2001, PÁL V. 2002). Ebben a helyzetben hozhat a telemedicina némi változást, és részben orvosolhatja az ellátórendszert jellemző fennakadásokat, ezért álláspontom szerint érdemes kitüntetett figyelmet fordítani erre az innovatív ellátási formára.

A kutatás indokoltságának további eleme - az előzőeken kívül - a téma földrajzi vonatkozásaiban keresendő. Annak ellenére, hogy a telemedicina az orvostudomány és az informatika szakterülete, az egészségföldrajzhoz is szorosan köthető, mivel átalakítja az egészségügyi ellátás térbeli jellemzőit (BÁN A. - PÁL V. 2015). Ez a földrajz szempontjából azért is különösen fontos, mert az egészségügyi erőforrások a térben egyenlőtlenül oszlanak el, és erősen korrelálnak a társadalmi-gazdasági fejlettséggel, továbbá a településhierarchia magasabb szintjein lévő települések általában kedvezőbb helyzettel rendelkeznek (UzzOLI A. et al. 2011, ViTRAI J. et al. 2008).

A telemedicina ugyanakkor az egészségügyi egyenlőtlenségek mérséklésének az egyik eszköze is lehet, amit azért szükséges kiemelni, mert egyrészt ezek a differenciák lényeges problémát jelentenek az ellátás biztosításában, másrészt a fizikai infrastruktúra széttelepítésére, illetve általában az egészségügyi erőforrások optimális elosztására sokszor nincs mód. Ugyanakkor a telemedicina a központoktól földrajzilag távoli, egészségügyileg hátrányos helyzetben lévő térségek számára is biztosíthatja az ellátást jelentős távolság megtétele nélkül. Így a fizikai távolság az ellátó és az ellátott között továbbra is megmarad, 
ennek ellenére az ellátás elérhetősége javul, információs távolsága rövidül. Ennek elsősorban olyan területeken van nagy jelentősége, ahol a telemedicinának nincs alternatívája, de az ellátás minőségét ott is emelheti, ahol az egészségügyi egyenlőtlenségek kevésbé érzékelhetők (BÁN A. - PÁL V. 2015, FicZere A. - KÖDMÖN J. 2011, GAGNON, M.P. et al. 2006, WoOTTON, R. 1999).

A telemedicina hatással van tehát a térbeli viszonyokra, azonban az egyelőre nem ismert, hogy miként fogja az egészségügyhöz kötődő térbeli és szervezeten belüli mozgásokat megváltoztatni a jövöben, hiszen vélhetően a telemedicina jelenleg „spin off” szakaszban, vagy már éppen azon túl van. Az előzőekben már felvázolt információtechnológiai forradalom ugyanis rendkívüli módon felgyorsította a korábban még jóval vontatottabban haladt fejlödést. Ezen túl az elmúlt években a telemedicina területén olyan mértékü előrelépés történt, amit vélhetően a nemzetközi publikációk - drasztikusan megnövekedett száma ellenére - sem tudtak maradéktalanul ismertetni (BREEN, G.M. - MATUSITZ, J. 2010, MARS, M. - SCOTT, R. 2012). E robbanásszerüen zajló folyamatok hatására az újonnan megjelent szakirodalmak eredményei is viszonylag gyorsan elavultak.

Kérdés az is, hogy milyen irányban fog fejlödni a telemedicina a közeli és távolabbi jövőben. Több szcenárió is elképzelhető, ezért különösen releváns, hogy egész pontosan milyen változásokat fog hozni az egészségügyben. Vajon az ellátórendszer minden területét áthatja-e és beépül teljesen a klinikai rutinba, vagy csupán egy technikai eljárásként szigetszerüen fogják alkalmazni? E jövőképtől függ ugyanis, hogy milyen mértékben változtatja meg a telemedicina a térbeli mozgásokat, pályákat, az ellátásban jelentkező területi egyenlőtlenségeket. A disszertáció ugyan a jelenlegi állapotot mutatja be hazai vonatkozásban, de valamelyest reflektál a jövőbeli várható trendekre is.

A fentieken túl több tényező is alátámasztja a telemedicina felértékelődését és itt különösen meghatározó a média szerepe. Noha ez az innovatív egészségügyi ellátási forma egyelőre inkább a tudományos életben hódít teret, amit az egyetemi (klinikai) kutatások és fejlesztések, illetve az intézmények közötti kooperációk gyarapodása bizonyít. Ráadásul az egészségpolitika tervei, szándékai is egyre inkább a telemedicina kiterjesztése felé mutatnak (EÁS ${ }^{1}$ 2015).

A nehézséget az jelenti, hogy annak ellenére, hogy a telemedicina egy elterjedőben lévő ellátási forma, a térbeli és társadalmi vonatkozásaira kevesebb figyelmet fordítanak a kutatók, pedig azok szerepe nem elhanyagolható (NICOLINI, D. 2006). Vélhetően ez annak is betudható, hogy meglehetősen kevés statisztikai adat áll rendelkezésre a távgyógyászattal kapcsolatban, ami akadályát képezi a kvantitatív kutatásoknak, noha a telemedicina térbeliségének elemzéséhez, térkapcsolatainak feltárásához erre sok esetben szükség lenne.

Ehhez kapcsolódva problémát generál, hogy jelenleg hiányzik egy olyan szisztematikus adatbázis, ami összegezné a telemedicina valamely részterületével foglalkozó egészségügyi szolgáltatókat (állami és/vagy magán). Ennek hiánya pedig feltehetően arra vezethető vissza, hogy az Országos Egészségbiztosítási Pénztár (OEP) (jelenleg Nemzeti Egészségbiztosítási Alapkezelő (NEAK)) nem minden telemedicinális ellátást (kivétel például a transztelefonikus EKG (TTEKG) [1]) finanszíroz (FICZERE A. 2010b, 2012b, 2012c), így értelemszerüen a hozzájuk tartozó adatok sincsenek központilag nyilvántartva, ugyanakkor a telemedicina földrajzi aspektusainak vizsgálatához kiindulópontként szükséges egy területi adatbázis összeállítása, melynek részleteit a módszertani fejezetben részletesen is kifejtem. Elsőként azonban a kutatás kérdéseinek, céljainak és hipotéziseinek bemutatására törekszem.

\footnotetext{
${ }^{1}$ Egészségügyi Ágazati Stratégia
} 


\subsection{A kutatás főbb kérdései, céljai, hipotézisei}

A kutatás indokoltsága és problematikája alapján a disszertációban több kérdést is célszerünek tartok megfogalmazni, amelyekre a későbbi fejezetekben megkísérlek választ adni.

A kérdések meghatározása, a koncepció megfogalmazása illeszkedik a kutatás egyes fázisaihoz, módszertani lépéseihez. E kérdések részben elméletiek, amelyek megválaszolására az empíria segítségével teszek kísérletet.

A dolgozat elméleti részében a kérdések értelmezési kereteit vizsgálom. Egyrészt elemzem a telemedicina terminológiai alapjait és földrajzi kapcsolódási pontjait, másrészt vizsgálom az ellátás elérhetőségére gyakorolt esetleges hatásait, illetve a gátló tényezőit. Továbbá néhány teóriát, amelyek az adaptáció kimenetelét magyarázzák. A disszertáció empirikus részében az elméleti fejezeteket kiegészítve a következő alkérdésekre keresem a választ hazai példán keresztül:

Mely egészségügyi szolgáltatók foglalkoznak jelenleg Magyarországon telemedicinával, és mely települések érintettek? Milyen attitüddel rendelkeznek a telemedicina megkérdezett prominens szereplői, illetve potenciális alkalmazói (pl. családorvosok, informatikusok stb.) e szolgáltatás iránt? Hogyan értékelhető a telmedicina térre és távolságra gyakorolt hatásai? Melyek a telemedicina legfőbb hatékonysági szempontjai? Mely tényezők gátolják és melyek segítik a telemedicina adaptálását? Milyen hatással van a telemedicina a már meglévő egészségügyi egyenlőtlenségekre? ${ }^{2}$ Miként változtatja meg ez a szolgáltatás az orvos-beteg közötti interperszonális kapcsolatot, illetve az egészségügyi szakemberek közötti viszonyrendszert? Hogyan befolyásolja a telemedicina az egyéb szervezeti kérdéseket, különös tekintettel az asszisztencia és a specialisták szerepét? S végül miként alakítja a telemedicina a távoli egészségügyi közösségeket?

A dolgozat fö kérdése pedig az előzőeket integrálva, a hazai és nemzetközi szakirodalommal összhangban arra vonatkozik, hogy: miként befolyásolja a telemedicina az egészségügyet érintő térbeli-társadalmi folyamatokat? Az egészségügyi kérdések ugyanis fontos részét képezik a fenti folyamatoknak, mivel a népesség széles körét érintik, és nagy mobilitással járnak.

Az előzőekből adódóan a kutatás fö célja a telemedicina ellátásra gyakorolt hatásainak feltárása a térbeli és társadalmi szempontok figyelembevételével. További célként jelenik meg - ami a disszertáció társadalmi hasznosulása is kíván lenni -, hogy a telemedicina még inkább bekerüljön a tudományos diskurzusba az egészségföldrajz eszközrendszerének segítségével. Mindezt annak érdekében, hogy a dolgozattal hozzájáruljak az egészségpolitikai döntéshozók és az egészségügyi szereplők informálásához, a telemedicina akceptálásához, illetve adaptálásához, és ezáltal az egészségügyi ellátórendszer területi és strukturális egyenlőtlenségeinek, valamint az egészségi állapot területi differenciáinak mérsékléséhez.

A disszertáció kérdései és céljai alapján - a kutatás során - az alábbi hipotézisek fogalmazhatók meg. (Ezek az empirikus részre vonatkoznak és az egyes módszertani lépésekhez köthetők):

1. hipotézis: Feltételezésem szerint az egészségügyi szolgáltatók elenyésző hányada foglalkozik telemedicinával. Ennek okát a finanszírozási problémákban és a rendszer kiépítésének költségében vélem felfedni. Tekintettel az egészségügyi ellátórendszer

\footnotetext{
2 Noha az egyenlőtlenségek vizsgálata általában kvantitatív módszerekhez kötött. Ennek ellenére a disszertációban elsősorban kvalitatív módszerek (félig strukturált interjúk) segítségével keresem a választ a telemedicina esetleges egyenlőtlenségekre gyakorolt hatásaira, ugyanis ehhez nem álltak rendelkezésre hatékonysággal kapcsolatos számítások, illetve kvantifikálható adatok.
} 
helyzetére, feltételezhetően annak szereplöi kevésbé fogékonyak az innovatív szolgáltatásokra és a telemedicina így nem szerepel a prioritási listán.

2. hipotézis: Álláspontom szerint a telemedicina tovább növeli az egészségügyi dolgozók leterheltségét. Ennek oka abban keresendő, hogy plusz feladatot generál az ellátás során, hiszen általában nem a mindennapi klinikai rutin része. Továbbá lehetőséget ad a specialisták gyorsabb elérhetőségére, ezáltal növelve szaktudásuk és munkaerejük távolból történő igénybevételét.

3. hipotézis: Feltételezésem szerint a telemedicina hazai viszonylatban is csökkentheti az egészségügyi egyenlőtlenségeket, vagy annak bizonyos típusait. Különösképpen a kvalifikált humánerőforrás hiányt, illetve az egészségi állapotban jelentkező területi differenciákat. Ennek okát abban látom, hogy a telemedicina a speciális szakértelem hatékonyabb területi eloszlását teszi lehetővé és támogatja a különféle egészségügyi paraméterek távolból történő monitorozását is.

4. hipotézis: Álláspontom szerint a telemedicina jelentősen redukálja az orvos-beteg közötti fizikai kapcsolatot, ami elszemélytelenedéshez vezet és erodálja a páciens és kezelőorvosa közti bizalmi viszonyt. Ennek okát abban vélem, hogy a telemedicinális ellátás során nem a beteg utazik, hanem az egészségügyi információ mozog a térben ezáltal növelve az elérhetőséget és hozzáférhetőséget -, ami a „face to face” orvosbeteg találkozok csökkenését vonja maga után.

5. hipotézis: Feltételezésem szerint az egészségportálokhoz köthető e-egészségügyi szolgáltatások - nemzetközi szakirodalommal összhangban - jelentős egészségnyereséget generálhatnak: az egészségügyi ellátás igénybevételét is redukálhatják, másrészt a páciens egészségi állapotát is jótékonyan befolyásolhatják. Ennek oka abban keresendő, hogy gyors egészségügyi tanácsot kaphatnak a betegek, amelyekhez egyébként csak személyes orvosi látogatással férhetnének hozzá.

Ebben az alfejezetben feltett kutatási kérdésekre a dolgozat további részében kívánok választ adni. Továbbá az előzőekben részletezett hipotézisek igazolására, illetve cáfolására az eredményekben és az összegzésben teszek kísérletet.

\subsection{A kutatás során alkalmazott módszerek}

A telemedicina hatásainak - annak összetettsége miatt - elemzése komplex szemléletet igényel, így kvantitatív és kvalitatív módszerek alkalmazását egyaránt szükségesnek tartottam, úgymint kérdőíves adatfelvételeket, félig strukturált interjúk készítését, illetve tartalomelemzést. Ugyanakkor a kutatás előrehaladtával egyre inkább eltolódott a hangsúly a kvalitatív módszerek alkalmazása felé, amit egyrészt a vizsgálat jellege (kvantitatív adatok hiányában a fókusz a szakmai tapasztalatokon volt), másrészt pedig a kutatási kérdések is determináltak.

Az előző fejezetben kifejtett kutatási kérdések egy része kvantitatív módszerekkel is megválaszolható, azonban ennek meghatározó akadálya a bevezetőben is jelzett területi adatbázis hiánya. Ugyanakkor a telemedicina hatásainak feltárása, a mechanizmus működésének megértése mindenekelőtt a témában jártas prominens szereplők tapasztalatai és véleményei útján ismerhetők meg. Ennek oka abban is keresendő, hogy az interjúpartnerek ${ }^{3}$ sok esetben részleteiben látják a telemedicinával kapcsolatos folyamatokat.

\footnotetext{
${ }^{3}$ A disszertációban az interjúpartner és az interjúalany kifejezéseket szinonimaként használom a szóismétlések gyakoriságának csökkentése érdekében. Annak ellenére, hogy a két fogalom szemléletbeli különbséget tükröz, a dolgozatban minden esetben interjúpartnerként tekintek az interjút vállaló szakemberekre.
} 
Mivel a kutatás az egészségföldrajzhoz kötődik, a dolgozatban értelemszerüen központi szerepet kapott a tér. A kutatás egyik kiinduló kérdése volt, hogy hol müködnek telemedicinális szolgáltatások hazánkban? A szakirodalmi áttekintésből erre nem, vagy csak parciálisan sikerült választ találni. Ehhez szükség lett volna ugyanis egy - már többször jelzett - területi adatbázisra, ami tartalmazza azokat az egészségügyi szolgáltatókat, amelyek Magyarországon telemedicinával foglalkoznak, vagy kapcsolatba kerültek vele korábban.

Mivel ilyen adatbázis létére hosszabb kutatói munka után sem találtam érdemben kielégítő bizonyítékot, így szakmai konzultációkat folytattam kilenc, témában elismert prominens szereplővel (elsősorban orvosokkal és informatikusokkal). A rövid (átlagosan 20 perces) diskurzusok során arról szereztem információkat, hogy mik a tapasztalataik a telemedicináról, hogyan vélekednek a hazai helyzetről, illetve van-e tudomásuk országos telemedicinális adatbázis létezéséről. A konzultációk eredményeként megerősítést nyert az a feltételezés, miszerint telemedicinát alkalmazó szolgáltatókról, vagy telemedicinális projektekről nem áll rendelkezésre sem teljes, sem részleges adatbázis országos léptékben.

\subsubsection{Az online kérdőíves adatfelvétel módszertani alapjai és nehézségei}

Az előzőekből adódóan primer adatgyüjtésbe kezdtem arról, hogy hol alkalmaznak telemedicinát. Ehhez egy önbevalláson alapuló online kérdőív tünt a legalkalmasabbnak, ami viszonylag egyszerü, gyors, olcsó és zárt csoport esetében, ahol kontrollálható a kitöltők köre, releváns információkat nyújthat. Éppen ez utóbbi lehetőség kihasználása céljából döntöttem e módszer mellett. Így olyan kérdöívet állítottam össze, ami, bár önkéntes volt, de nem anonim, ugyanis a területi adatbázis összeállításához szükséges volt a szolgáltatók működési helye, amit az intézmények nevéböl történő azonosítás (e-mail címből visszavezetve) alapján határoztam meg.

Az online kérdőívhez az ÁNTSZ területi ellátási kötelezettséggel rendelkező egészségügyi szolgáltatók listája biztosította a kiindulási alapot, ami, bár nem túl naprakész adatbázis, azonban széleskörüen átfogja az egészségügyi ellátókat. Ezeket a szolgáltatókat intézményi és vállalkozói csoportra bontottam profiljuknak megfelelően és ehhez igazítottam a számukra kiküldött kérdőívek megszólításait, kérdéseit, ugyanakkor ezek tematikában nem tértek el egymástól (lásd Melléklet 1.).

E munkafolyamatot egy, az egészségügyi szolgáltatók e-mail címeit tartalmazó adatbázis összeállítása előzte meg. Ennek során az ÁNTSZ és az Állami Egészségügyi Ellátó Központ (ÁEEK) (korábban GYEMSZI) listáján szereplő e-mail címeket vettem alapul, amelyeket kiegészítettem az interneten és az egyes intézmények honlapján található elektronikus levélcímekkel.

Az online kérdőívet tartalmazó e-maileket mind az intézményi, mind a vállalkozói csoport esetében legalább három alkalommal küldtem ki, különböző időszakokban, általában 3-4 hetes periódusonként, a válaszadói arány növelése érdekében. Ennek erősítéseként a fekvőbeteg-szakellátók és a járóbeteg-szakellátók esetében telefonos, elektronikus megkeresést és webes információgyüjtést is alkalmaztam. Az előbbi két, az e-mailben történő adatkérések pedig egy alkalommal történtek a fent jelzett intézményeknél. Ezenfelül, amennyiben relevánsnak mutatkozó jelét találtam az interneten, illetve az egészségügyi intézmény honlapján a telemedicinális szolgáltatás meglétének, az szintén rögzítésre került az adatbázisban. 
A kérdőívek kitöltése 2013 decembere és 2014 áprilisa között történt, melynek során 508 db e-mail címre küldtem ki az online kérdöívet és ebből 206 db érkezett vissza, amiből $170 \mathrm{db}$ intézményi és $36 \mathrm{db}$ vállalkozói típusú volt. A telefonos és e-mailes megkereséseknek köszönhetően azonban $254 \mathrm{db}$ válasz realizálódott, így pontosan 50 százalékos válaszadói arányt sikerült elérni, ami önkitöltős kérdőíveknél és főként online kutatásoknál - a szakirodalom alapján - akceptálható (BABBIE, E. 2008, HÉRA G. - LiGETI GY. 2005).

Az adatfelvétel eredményeinek interpretálásánál, a szolgáltatók esetében az intézményi és vállalkozói kategóriát együtt kezeltem, tekintettel az utóbbi csoport tagjainak alacsony részvételi hajlandóságára.

A kérdőívezés alatt mindösszesen hét alkalommal utasították el nyíltan a válaszadást, ami feltehetően jelentősen nem torzította az eredményeket. Természetesen arról nem rendelkeztem semmilyen információval, hogy a kitöltetlen kérdöívek mekkora részénél merült fel a „bújtatott” elutasítás és egyéb hátráltató tényezők (pl. idő hiányában félbehagyott, elfelejtett kérdőívek).

A kutatás során ugyanakkor számos nehézségbe ütköztem, amelyek jelentősen befolyásolhatták a kapott eredményeket, és amelyeket a kérdőívekből készített adatbázis értelmezésénél figyelembe kell venni.

Egyrészt ide tartozott az e-mail címek validitása és a levélszürö beállításai, amelyek alapvetően determinálták az online kérdőívek megérkezését. Ehhez kapcsolódva szintén lényeges kérdés volt a kérdőívet kitöltő kompetenciája, aminek lényege, hogy telemedicinában jártas egészségügyi szakember (mindenekelőtt orvos) kapja meg a kérdéseket, és ezáltal hiteles válaszok szülessenek.

További fontos kérdésként merült fel a téma specifikusság, hiszen a telemedicina diskurzív fogalom, így mást érthetett alatta a kitöltő, mint amit a kutató, és ez alapvetően befolyásolhatta a kérdésekre adott választ is.

A szolgáltatók rendkívül heterogén csoportot alkottak, mivel az ÁNTSZ listáján kórházak, járóbeteg-szakellátók, magánszolgáltatók stb. is szerepeltek. Ebből adódóan nehéz volt minden csoportnak releváns kérdéseket feltenni, amit az intézményi-vállalkozói csoportra bontás csak részben orvosolt.

A megkérdezettek nem magánszemélyek voltak, hanem elfoglalt és leterhelt egészségügyi dolgozók, ami szintén nehézséget jelentett.

Noha az alkalmazott online kérdőíves rendszer felhasználóbarát volt, ennek ellenére sokszor problémát okozott a használata, ami szintén csökkenthette a kitöltési hajlandóságot.

Szintén nehézséget jelentett a kutatással szembeni előítéletesség. Ebből adódóan a kitöltők attitüdje alapvetően meghatározta e vizsgálati módszer sikerét.

A kérdőíves adatfelvétel eredményeinek értékelése csak a fent jelzett nehézségek számbavételével lehetséges. E kutatási lépés feltehetően nem ad minden tekintetben megbízható eredményt, így ez fenntartással kezelendő.

Az előzőek ellenére azonban előnye, hogy segítséget nyújtott egy területi adatbázis összeállításához, ami tartalmazta a telemedicinát alkalmazó szolgáltatókat. Valószínűsíthetően ez nem egy teljes és ideális adatbázis, ami egyébként is egy statikus állapotot tükröz - annak ellenére, hogy ez egy dinamikus viszonyt feltételez -, így a jövőben folyamatos bővítést igényel. Ennek megfelelően az online kérdőíves adatfelvétel és annak eredménye lényegében csupán kiindulópontja volt a kutatás további, érdemi részének, amit anélkül nem, vagy csak részben lehetett volna kivitelezni. 


\subsubsection{A félig strukturált interjúk módszertani alapjai és nehézségei}

A kutatás kérdéseinek megválaszolásához szükséges volt kvalitatív módszert, jelen esetben félig strukturált interjúkat is alkalmazni. Ezt egyrészt az indokolta, hogy az előzőek során kifejtett kérdőíves adatfelvétel csak részben járt sikerrel, másrészt a telemedicina különböző hatásainak feltárása, a mechanizmus megértése olyan módszert igényelt, ami lehetőséget adott az egyes kérdések részletesebb kifejtésére. Ehhez szükséges volt az egyes telemedicinával érintett kulcsszereplök megkeresése, akik a gyakorlatban is alkalmazták ezt az ellátási formát, vagy rálátásuk volt ezekre a folyamatokra. Ennek köszönhetően a távgyógyászat egyes „rejtett” aspektusait is sikerült felfedni, amihez az interjú megfelelő módszernek bizonyult.

Az interjúpartnerek kiválasztásához segítséget nyújtott a fentiek során már többször előkerült területi adatbázis. Így az egyes interjúalanyokat azon egészségügyi szolgáltatók közül választottam, amelyek az online kérdőívben jelezték ilyen irányú tevékenységüket. A kiválasztást követően ezeket a szolgáltatókat - ami végül is az Állami Egészségügyi Ellátó Központ (ÁEEK) fenntartása alá tartozó kórházakat jelentette - e-mailben felkerestem és felkértem illetékes kollégájukat egy interjúra. Továbbá az ún. „hólabda” módszer segítségével - az interjúpartnerek kapcsolati hálóját felhasználva - tovább bővítettem a potenciális interjúalanyok számát (1. ábra).

\section{1. ábra: Az interjúpartnerek megoszlása települések szerint}

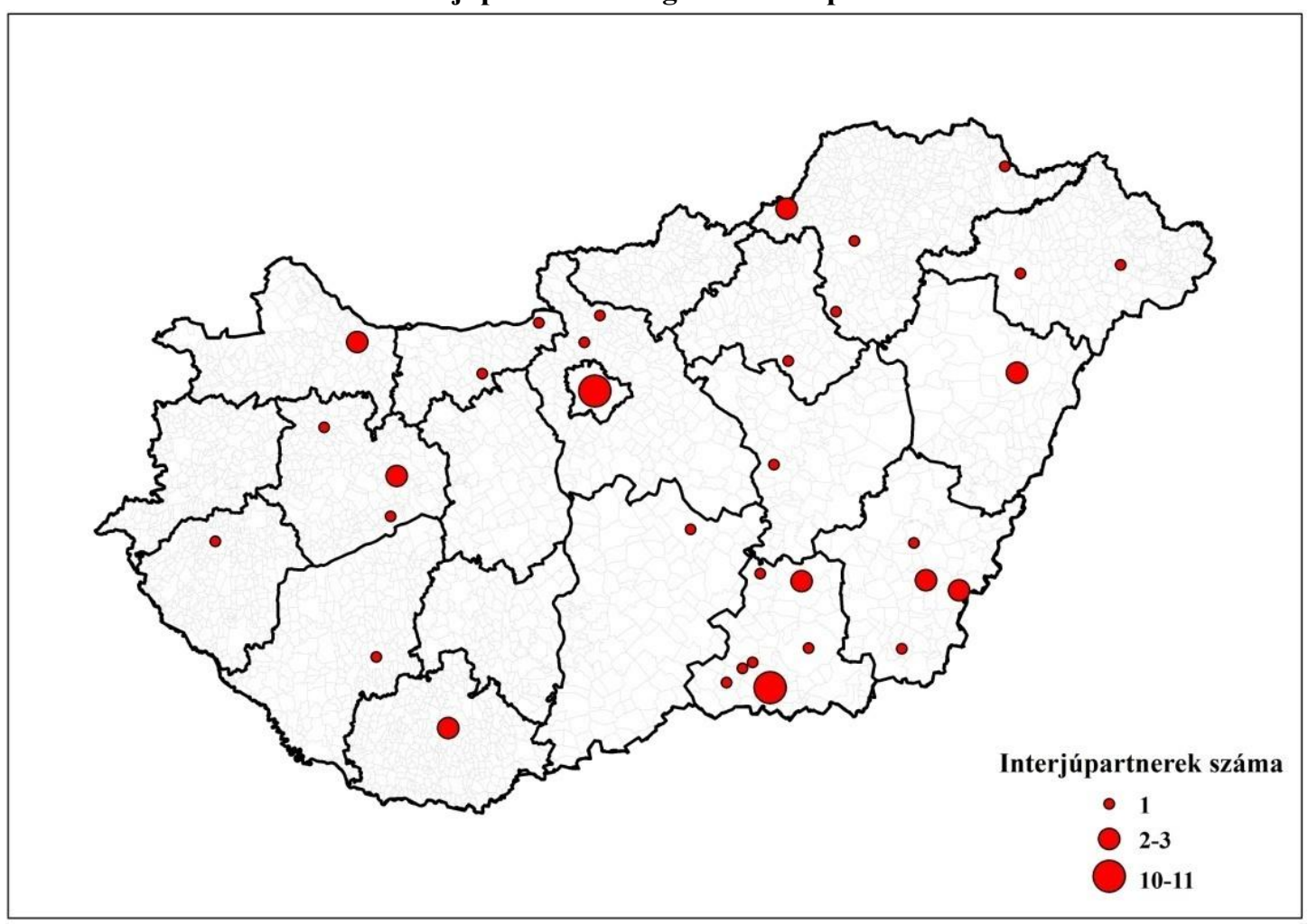

Az interjúpartnerek kiválasztásánál törekedtem arra, hogy azok viszonylag szórtan helyezkedjenek el az országban (lehetőség szerint ne legyenek túlságosan felülreprezentáltak egyes települések, illetve térségek), továbbá minél több érintettet szólaltathassak meg, és hogy különböző szakorvosoktól (pl. belgyógyász, kardiológus, radiológus stb.) kapjak információkat. 
Az interjúk készítésére 2014 augusztusa és 2015 októbere között került sor. Ebben az időintervallumban összesen $63 \mathrm{db}$ interjú készült el, amelyeket e-mailen és/vagy telefonon történő egyeztetések előztek meg (1. táblázat). Az interjúk során szakorvosokat, háziorvosokat, egészségügyi felsővezetőket ${ }^{4}$ és informatikusokat egyaránt megszólítottam. Az interjúpartnerek többsége azonban az első két csoport, és azon belül is inkább a szakorvosok (és különösen a radiológusok) közül került ki. Ezzel ellentétben az egészségügyi vezetők és informatikusok közül ebben az időszakban mindössze 2-3 fö állt rendelkezésre. Ez utóbbi interjúcsoportok tagjaival egyébként is meglehetősen nehéz volt időpontot egyeztetni elfoglaltságuk miatt. Ugyanakkor az érintett egészségügyi vezetök és informatikus szakemberek - a kevés interjúszám ellenére - hasonlóan vélekedtek a telemedicináról.

Az interjúk többségét személyesen (54) folytattam le, de Skype (4), telefon (3) és videokonferencia (2) adta lehetőségeket is használtam azok elkészítéséhez. Egy interjú átlagos időtartama 40 perc körül alakult, ugyanakkor igen nagy szélsőértékek között mozgott: a legrövidebb hozzávetőlegesen mindössze 10 percet tett ki (a második legrövidebb 13 perc), míg a leghosszabb 135 percet (a második leghosszabb 103 perc). Ezek az értékek általában nem tartalmazták az interjúk felvezetésére és lezárására szánt időt. Mindössze egy esetben szakította félbe az interjút egyik interjúpartner sürgős szakmai tevékenységre hivatkozva (ami később sem lett befejezve), ebből is adódott a rövid, 10 perces időtartam.

\begin{tabular}{|c|c|c|}
\hline & Szakterület & $\begin{array}{c}\text { Megoszlás } \\
\text { (fó) }\end{array}$ \\
\hline & Radiológus & 21 \\
\hline & Belgyógyász & 7 \\
\hline & Nőgyógyász & 3 \\
\hline & Idegsebész & 3 \\
\hline & Bőrgyógyász & 2 \\
\hline & Kardiológus & 2 \\
\hline & Neurológus & 2 \\
\hline & Genetikus & 1 \\
\hline & Gyermekgyógyász & 1 \\
\hline & Patológus & 1 \\
\hline & Sebész & 1 \\
\hline & Rezidens & 1 \\
\hline & Háziorvos & 13 \\
\hline & Egészségügyi vezető & 2 \\
\hline & Informatikus & 3 \\
\hline & Összesen & 63 \\
\hline
\end{tabular}

Az interjúk 33 települést érintettek (az interjúpartnerekhez kapcsolódó intézmények müködési vagy telephelye szerint) hazánkban, amelyek közül tízet több esetben is. Az interjúalanyok ajánlásai alapján sikerült jelentősen bővíteni az elkészített interjúk számát. Ennek során olyan orvosokkal is készítettem interjút (5 interjúpartner), akik csak elméleti szinten kerültek kapcsolatba a telemedicinával - ami nem jelenti azt, hogy a témára nem volt rálátásuk -, de a gyakorlatban még nem alkalmazták, így ezeknek az interjúknak az eredményei csak korlátozottan vehetők figyelembe.

\footnotetext{
${ }^{4}$ Egészségügyi felsővezető alatt jelen helyzetben az állam fennhatósága alá tartozó egészségügyi szolgáltatók, intézmények felett diszponáló szervek vezető beosztású tagjait értem.
} 
Mivel az interjúk félig strukturáltak voltak, azok készítése elöre konstruált interjúvázlatok alapján történtek, amelyek némileg különböztek az egyes aktorok csoportjainál (pl. szakorvos, háziorvos, informatikus stb.), de tematikában megegyeztek (lásd Melléklet 2-5.). Ebben a tekintetben vizsgáltam többek közt a telemedicina hatékonysági vonatkozásait, térre és távolságra, az egészségügyi egyenlőtlenségekre, illetve az orvos-beteg kapcsolatra gyakorolt hatásait és egyéb szervezeti kérdéseit.

Noha az interjúk során törekedtem a sorrendiség megtartására - az értékelhetőség egyszerüsítése céljából, illetve annak érdekében, hogy az interjúpartnerek hasonló impulzusokat kapjanak -, ez egyre inkább kötetlenebbé vált.

Az interjúk rögzítésére a kézírásos jegyzeteken túl digitális diktafont is alkalmaztam, ami lehetőséget adott a szöveg átírására, az interjúpartner és a nonverbális jelek jobb megfigyelésére. Az interjúalanyok döntő többsége nem kifogásolta az interjú hanganyagának rögzítését, azonban néhány interjúpartner csak a diktafon mellőzésével vállalta az interjút, így ezekben az esetekben a jegyzeteimre és az emlékezetemre hagyatkozhattam. Az interjúk rögzítését követően azok transzkriptálására is sor került, melyben segítséget nyújtottak az SZTE TTIK Gazdaság- és Társadalomföldrajz Tanszék demonstrátorai és hallgatói. Erre azért is volt szükség, mert az interjúk hanganyagának szövegként való minél pontosabb átírása meglehetősen időigényes munkafolyamatot jelentett.

A leírt szövegeket előzetes szempontok szerint elemeztem választ keresve a dolgozat fö- és részkérdéseire. Ebben a tekintetben azt vizsgáltam, hogy az egyes interjúpartnerek milyen hosszan, mennyire lényegre töröen és milyen érzelmi töltéssel válaszolnak az interjú kérdéseire. Ezenfelül mit tartanak relevánsnak, mi az, amit kiemelnek válaszaikban és ehhez kapcsolódva melyek a legfőbb kulcsszavak. Az interjúkat követően minden esetben rövid, általában egy oldalas feljegyzéseket készítettem azok körülményeiről, a benyomásaimról, az elmondottakról és a nonverbális jelekről, amelyeket később figyelembe vettem.

Az online kérdőíves adatfelvétel mellett az interjúk esetében is tapasztaltam nehézségeket, amelyek megnehezítették az eredményes munkát. Egyrészt ilyen tényező volt a kutatás engedélyeztetése - ez a korábbi módszertani lépésnél is felmerült -, ami néhány esetben jelentősen késleltette az interjú elkészítését.

Másrészt az előzőekhez is kapcsolódóan a legtöbbször jelentős időeltolódással kellett számolni a felkérő e-mailek kiküldése és a potenciális interjúpartnerrel való időpont egyeztetése, illetve a tényleges interjú elkészítése között, ami hozzájárult ennek a kutatási fázisnak a kitolódásához.

Harmadrészt az interjúvázlatokat és az interjúkat 30-40 percesre terveztem, ennek ellenére az időkeretet több esetben is csökkenteni kellett, hiszen tekintettel az etikai szempontokra, az ellátás minden esetben prioritást élvezett a kutatással szemben. Így meglehetősen korlátozott számú kérdést lehetet egy interjú során feltenni, illetve kevesebb idő állt rendelkezésre ezek részletesebb kifejtésére, vagy éppen az interjú lezárására.

További problémát jelentett az is, hogy a hangfelvételek minősége sok esetben gátolta az interjúk eredményes átírását és értékelését, amit az ismételt visszahallgatások csak részben orvosoltak. Fentieken túl természetesen több, mindenekelőtt külső tényezők (pl. személyes interjúknál a távoli térségek és települések elérhetősége tömegközlekedéssel) miatt bekövetkező nehézségek hátráltatták az interjúk elkészítését és kiértékelését. 


\subsubsection{A családorvosi kérdőíves adatfelvétel módszertani jellemzői}

A családorvosok az interjúpartnerek nehezen megközelíthető csoportját alkotják, ugyanis túlnyomó többségük nem foglalkozik telemedicinával és meglehetősen nehéz azok felkutatása is, akik használják ezeket az innovatív ellátási forma adta lehetőségeket. Ebböl adódóan az interjúk kiegészítéseként kísérletet tettem a háziorvosok telemedicinával kapcsolatos attitüdjeinek mérésére egy további kérdőíves adatfelvétel segítségével. Ennek köszönhetően fény derült arra, hogy mi a véleménye (miért nem használják, milyen területeken lehetne alkalmazni, mit várnak el tőle, stb.) azoknak a háziorvosoknak a telemedicináról, akik nem alkalmazzák. Ez a kutatási lépés egy korábbi háziorvosi interjúpartner ötletéből származott, aki segítséget nyújtott ennek lebonyolításához.

A kérdőíves adatfelvétel így egy közös kutatás keretében valósult meg az SZTE Családorvosi Intézet munkatársainak közreműködésével. A kérdőívek kitöltésére két alkalommal került sor 2015 szeptembere és októbere között háziorvosi továbbképzések keretében. Ennek eredményeként 49 db önkitöltős (és anonim) kérdőívet sikerült visszakapni a megkérdezettektől. Ez a módszer szintén csak részben járt sikerrel, ugyanis a kérdőívet kitöltők száma nem érte el a statisztikai alapsokaságot, ezért a százalékos megoszlás számítása meghiúsult. Ezenfelül további problémát jelentettek a félig kitöltött és az értékelhetetlen kérdőívek is, amelyek sok esetben a megkérdezettek kompetenciájának hiányára és/vagy az érdektelenségre engedtek következtetni.

Az alacsony elemszám ellenére - véleményem szerint - a kérdőíves adatfelvétel eredményei a feltett kérdések megválaszolásához közelebb vihetnek. A továbbképzés keretében megvalósult felmérés ugyanis lehetőséget adott az ország különbözö területein praktizáló, sajátos szempontokat hangsúlyozó háziorvosok telemedicinával kapcsolatos attitűdjeinek megismerésére. A családorvosok elfoglaltsága, leterheltsége miatt ez személyes megkereséssel (jelentős energia befektetés ellenére) vélhetően nem valósulhatott volna meg. Ezenfelül rávilágított az adaptáció hiányának okaira az alapellátásban, ami segítséget nyújthat ilyen irányú stratégiák kidolgozásában. Noha a válaszadók száma nem érte el a statisztikai alapsokaságot, álláspontom szerint a közel félszáz orvos megkeresése és az általuk nyújtott információ alapján is vonhatók le következtetések, természetesen figyelembe véve az említett korlátokat.

\subsubsection{A kutatás során alkalmazott tartalomelemzés módszertani jellemzői}

A telemedicina prominens szereplőivel készített interjúk rávilágítottak a távgyógyászat mechanizmusának müködésére, nem adtak ugyanakkor kielégítő választ egyes e-egészségügyi szolgáltatások (jelen esetben az egészségportálok) egészségügyi közösségekre gyakorolt hatásaira. Ezenfelül szükséges volt az interjúk során kapott eredményeket is igazolni.

Ennek megfelelően tartalomelemzésre is sor került 2016 januárja és februárja között, a kutatás végső lépésében. Ennél fontos kérdés volt, hogy milyen előnnyel járhat ezeknek a portáloknak a használata az egészségügy szereplőinek, különösen tekintettel az ellátást végző orvosoknak, illetve a betegeknek. Időhiány miatt mindössze egy - egyik legnagyobb hazai egészségportál került kiválasztásra.

Ennek weblapján, az „orvos válaszol” rovaton belül a tíz, legtöbb kérdést tartalmazó témát választottam ki. A kérdésszám alapján ebbe a csoportba tartozott a fogamzásgátlás és a terhesség is, amit helyettesítettem a sorban következő, legtöbb kérdéssel rendelkező témakörökkel, ugyanis ezek nem betegséget, hanem inkább állapotot jelöltek. A tartalomelemzés során sorrendben a nőgyógyászati, a mozgásszervi, a bőrgyógyászati, az 
emésztőrendszeri, az egyéb, a neurológiai, az urológiai, a szív- és érrendszeri, az endokrin, és végül a fül-orr-gégészeti témaköröket érintettem.

Így azt az aggregátumot, amiből a mintavétel történt az ,internetes páciensek” által feltett összesen 51.302 kérdés, és az azokra adott szakszerü válaszok adták. A tartalomelemzés során az egészségügyi szakemberek válaszait elemeztem, azonban azok értelmezéséhez természetesen elengedhetetlen volt a kérdések megismerése is. Minden egyes témakörnél egyszerü véletlen mintavétellel, véletlenszám-generátor [2] segítségével jelöltem ki a kérdések és a válaszok 5 százalékát, melynek eredményeként összesen 2.566 db-ot vizsgáltam.

Alapvetően két objektív indikátor (orvoshoz fordulás, terápiás javaslat) segítségével elemeztem a kérdésekre adott válaszokat. Az első indikátor arra vonatkozott, hogy előfordulte a válaszadó egészségügyi szakember üzenetében az, hogy a beteg forduljon orvoshoz, vagy esetleg utalt-e rá. Tehát ez megjelenhetett nyíltan a válaszokban, egyértelmű szófordulatokkal, mint pl. „keresse fel háziorvosát”, vagy ,ehhez kivizsgálás szükséges”, amiben az egészségügyi szakember kvázi utasította a pácienst, hogy jelenjen meg valamely ellátó intézmény látókörében.

Ugyanakkor a tartalomelemzés során a „rejtett” válaszok is elemzésre kerültek, amelyek arra engedtek következtetni, hogy a betegnek szakembert kell felkeresni. Ennek egyik példája, amikor a válaszadó csupán azt nyilatkozta, hogy „,vizsgálat nélkül pontos választ nem lehet adni”. Továbbá olyan szituációk is előkerültek, amelyben az orvos látszólag csupán terápiás tanácsot adott, miszerint például „használjon adott készítményt”, ami több esetben vényköteles, kvázi legalább az alapellátás szintjén szintén orvos-beteg találkozót generált ${ }^{5}$.

A másik indikátor pedig arra vonatkozott, hogy kapott-e érdemi terápiás javaslatot a beteg. A kezelési javaslatnál éppúgy megjelenhettek konkrét gyógyszerek nevei, vagy azok hatóanyagai, az alkalmazásuk gyakoriságára vonatkozó szabályok, illetve egyéb egészséges életmóddal kapcsolatos tanácsok.

A fentieken túl egy harmadik kategóriát is szükséges volt bevezetni, ami az előző kettő kizárásán alapult. Ez mindössze azt tette mérhetővé, hogy a beteg kapott-e választ a (általában tájékozódó) kérdésére, vagy sem, abban az esetben, ha a szakember visszajelzését nem lehetett a fenti két indikátor alapján egyértelmúen besorolni, mivel a kérdés és a rá adott válasz típusa azt nem tette lehetővé.

Feltételezhető, hogy amennyiben megjelenik az orvoshoz fordulás szükségessége, akkor az egészségügyi ellátórendszert kevésbé tehermentesíti ez az internetes szolgáltatás, és ezáltal az orvosok leterheltségét sem segíti. Ugyanakkor az is valószínüsíthető, hogy a megfelelő (egyénre szabott) terápiás javaslat egészség-nyereséggel is járhat a beteg szempontjából, amennyiben azt megfogadja.

Összességében tehát a kutatás során többféle (kvantitatív és kvalitatív) módszert alkalmaztam - úgymint kérdőíves adatfelvételeket, félig strukturált interjúkat és tartalomelemzést - annak érdekében, hogy több irányból megközelítve, minél pontosabb képet kaphassak a telemedicina térbeli-társadalmi aspektusairól, egészségügyi vonatkozásairól. Különös tekintettel érintve a távgyógyászatnak az egészségügy területi egyenlőtlenségeire, az interperszonális viszonyrendszerre (orvos-beteg kapcsolat), az ellátás hatékonyságára gyakorolt hatásait.

\footnotetext{
${ }^{5}$ Ilyen esetekben szükséges volt ellenőrizni az adott terméket az egyes gyógyszertárak weblapján, hogy vényköteles-e.
} 


\section{A telemedicina általános kérdései és kapcsolata a földrajzzal}

\subsection{A telemedicina fogalmi kérdései: terminológiai alapok és részterületek}

A telemedicina - mint innovatív egészségügyi ellátási forma - hatásainak számbavételét megelőzően érdemes röviden tisztázni, hogy mit is jelent maga a telemedicina, milyen formái léteznek és hol alkalmazható az egészségügyi ellátáson belül.

Általában elmondható, hogy a telemedicina diskurzív fogalom, hiszen sokan, sokfélét értenek alatta, és a tudományos életben sincs konszenzus arról, hogy mi tartozik a tárgykörébe (BASHSHUR, R.L. 1997). (A telemedicinának számos hazai szinonimája is ismert, mint például a távgyógyászat, távellátás, távorvoslás stb. ${ }^{6}$ Egy - a WHO által is hivatkozott - tanulmány (Sood, S.P. et al. 2007) szerint 104 féle kifejezést tartanak számon az ide tartozó ellátási formák megnevezésére, ugyanakkor ezekben a definíciókban közös, hogy a telemedicinát az infokommunikációs technológiák és az egészségügyi ellátás egyfajta integrációjaként értelmezik. Ez azt jelenti, hogy e technológiák az ellátás nélkülözhetetlen részévé válnak és így alapvetően determinálják azt (WHO 2010).

Az Egészségügyi Világszervezet egyik rövidített meghatározása szerint a telemedicina „magában foglalja az információs és kommunikációs technológiák által meghatározott egészségügyi szolgáltatások biztositását, különösen, ahol a távolság akadályozza az egészségügyi ellátást” (WHO 2011 p. 11). Az egészségtudományi fogalomtár meghatározása utal az érintettekre is, miszerint a távellátás során az orvos és a beteg, továbbá az orvos és az orvos (vagy más egészségügyi szakember) közvetlenül nem találkozik, csak távoli adatátviteli rendszeren keresztül érintkezik [3].

A fentiek alapján a disszertációban telemedicina alatt minden olyan infokommunikációs technológia által támogatott egészségügyi (orvosi) tevékenységet értek, amikor az ellátás, vagy annak bizonyos része (pl. diagnózis felállítás, tanácsadás stb.) nem kötődik az egészségügyi szereplök (orvos, beteg) fizikai jelenlétéhez.

A nemzetközi szakirodalomban a telemedicina (telemedicine) terminus mellett elterjedtek a távegészség (telehealth) és az elektronikus egészségügy (e-health) kifejezések is, melyeket sokszor tévesen szinonimaként kezelnek. Az első kettő között lényeges különbség, hogy a telemedicina csupán az orvosok által nyújtott (táv)ellátást foglalja magában, míg a második esetében általában az egészségügyi (szak)személyzet által biztosított szolgáltatásokról van szó (WHO 2010).

A telehealth magában foglalja a személyre szabott és a nem személyes egészségügyi szolgáltatásokat is, ezért jóval tágabb kategória a telemedicinánál. A távegészségbe ugyanis beletartozik az egészségfejlesztés, betegségmegelőzés, az oktatás és a különböző adminisztratív munkák is. A legbővebb csoportot ugyanakkor az e-health adja, ami tartalmazza a web alapú, elektronikus úton történő egészséggel kapcsolatos szolgáltatásokat. Ez nem csupán az ellátórendszerben keletkező digitális adatok infokommunikációs technológiák által támogatott előhívásával és megosztásával kapcsolatos teendőket jelöli, hanem általában az interneten elérhető egészségügyi szolgáltatásokat is (BASHSHUR R.L. 2000, Beuscart, R. et al. 2014, Cunningham, S.G. et al. 2014, LoPeZ, A.M. 2014, MARS, M. - Scott, R.E. 2010, Scott, R.E. 2009, Starren, J.B. - Nesbitt, T.S. - Chiang, M.F. 2014).

\footnotetext{
${ }^{6}$ A disszertációban a szóismétlések elkerülése, a szöveg gördölékenyebbé tétele miatt a telemedicina szinonimájaként értelmezem és használom a távgyógyászat, a távellátás és a távorvoslás kifejezéseket.
} 
$\mathrm{Az}$ e-health két fö részre bontható: egyrészt telehealth-re, másrészt egészségügyi információs rendszerre. Ebben a felosztásban a telehealth-en belül a telemedicina mellett külön terminusként jelenik meg a távgondozás (telecare) is. Ez pedig különösen az idősek és a különböző egészségkárosodott emberek mindennapjait támogató, folyamatos (egészségügyi) monitorozását jelöli. A távgondozás esetében meghatározó az átfedés részben a telemedicinával, részben pedig a szociális ellátással (BEUSCART, R. et al. 2014).

Az ábrán az e-health-en belül, a telehealth mellett megjelenik az egészségügyi információs rendszer is (2. ábra), ami lehetővé teszi az egészségügyi ágazatban jelentkező digitális adatok távolságtól független használatát, tárolását és továbbítását (BEUSCART, R. et al. 2014, SCOTT, R.E. 2009).

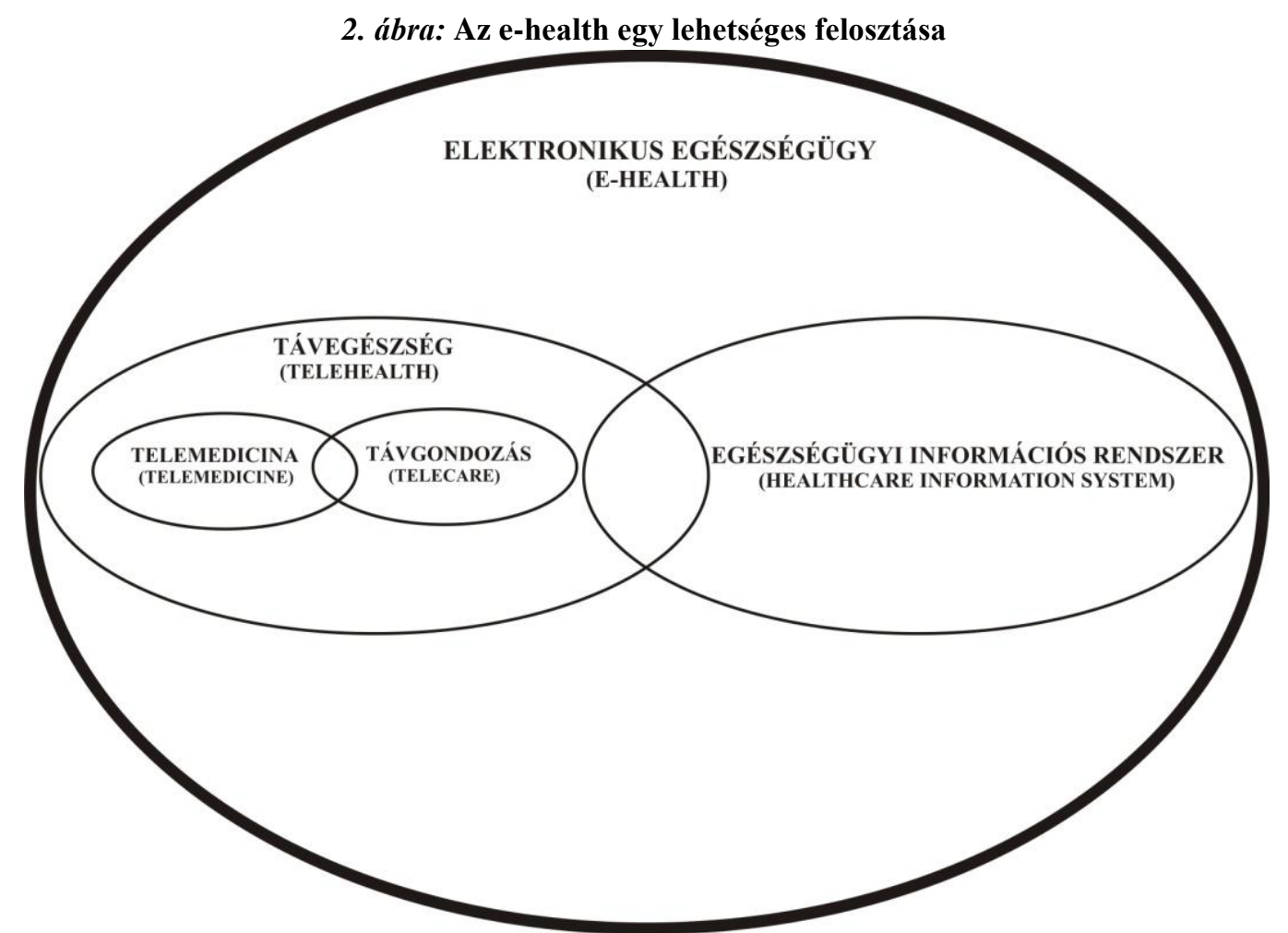

(Forrás: BEUSCART, R. et al. 2014 alapján szerk.: Bán A. 2016)

A telemedicina is további területekre bontható, ami erősíti a komplexitását. A távkonzílium során két vagy több orvos (esetleg más egészségügyi szakember) konzultál egy beteg állapotáról, diagnózisáról (videokonferencia, vagy egyéb telekommunikációs technológia segítségével). A távdiagnosztika esetében a vizsgálatot végző egészségügyi szakember és a diagnózis felállítója nem ugyanazon a helyen tartózkodnak, hanem térben szeparáltan, így a kapcsolatot közöttük az infokommunikációs technológiák teremtik meg. (FICZERE A. 2010a, 2010b). A távdiagnosztikának egy sajátos területe a teleradiológia (távleletezés) ${ }^{7}$, ami különböző radiológiai képek (RTG, CT stb.) infokommunikációs technológián keresztüli küldését és diagnosztikai célból történő távoli értékelését jelöli (WHO 2010). A távmanipuláció tekintetében távérzékelő (és robotkar) segítségével valósítják meg a beavatkozásokat, mütéteket. A távfelügyeletnél pedig különböző egészségügyi paramétereket mérő készülékek teremtik meg a monitorozás lehetőségét. Ezeket az adatokat a pácienstől térben távollévő egészségügyi személyzet értékeli ki [3] (FICZERE A. 2010a, 2010b).

\footnotetext{
${ }^{7}$ A disszertációban a teleradiológia és a távleletezés kifejezéseket szinonimaként használom.
} 
A fent említett föbb típusok orvos-beteg, vagy orvos-orvos kontaktuson alapulnak, melyeknek alapvetően három megvalósulási formája ismert. A kapcsolat történhet közvetlen kép és hangátvitellel, ún. élőadásként (élő audiovizuális kapcsolat), közvetlen kommunikációt nem biztosító, tárolt és továbbított képek (store and forward) küldéseként, valamint az előző kettő ötvözeteként (távoli betegmonitoring). Az audiovizuális kapcsolat távkonzílium keretében valósul meg, míg a képtovábbítást diagnosztikai célból használják elsősorban (DARAGÓ L. et al. 2010, FicZERE A. - KÖDMÖN J. 2011, SZABÓ Cs.A. - JÁvOR A. 2008).

A leírt technikai eljárások az orvostudomány összes szakterületén jelen vannak, például a radiológiában, a kardiológiában, a patológiában, a dermatológiában, a pszichiátriában stb. (TÚRY F. - VINCZE G. 2008, VINCZE G. - TÚRY F. - RESS K. 2004). Ezenfelül a telemedicina meghatározó szerepet kaphat például olyan népbetegségek gondozásának támogatásában is, mint például az allergia (BÁN A. 2013b, BÁN A. - NAGY GY. 2013, KRISHNA, M.T. - KNIBB, R.C. - HuISSOON, A.P. 2016). A távorvoslás azonban nem csak a szakellátásban, hanem az alapellátásban is kiválóan alkalmazható, mindenekelőtt a különböző egészségügyi paraméterek (pl. vércukor, vérnyomás értékek) monitorozásában (BÁN A. 2013d, FICZERE A. 2010a). Ezenkívül egyre nagyobb szerepet kap az oktatásban (távoktatás), orvosképzésben is, ami egyrészt feltehetően a hatékonysági kérdéseire vezethető vissza, másrészt pedig valószínüsíthetően arra, hogy gyakorlatorientáltabbá teheti a képzést egyes orvosi esetek demonstrálásával (FICZERE A. 2010a, 2012a).

A telemedicina tehát meglehetősen komplex egészségügyi ellátási forma, aminek az orvostudományon belüli felhasználása már napjainkban is igen széleskörü. Noha a távgyógyászat ellátásbeli integrációja döntően az elmúlt évtizedek terméke, fejlődése jóval korábbra nyúlik vissza (CRAIG, J. - PATTERSON, V. 2005), melynek áttekintése talán a térrel kapcsolatos viszonya szempontjából is célszerünek tünik.

\subsection{A telemedicina rövid története a 18-19. század fordulójától napjainkig}

A telemedicina történetisége több szempontból is bizonyítja annak földrajzzal való kapcsolódását. Ez arra vezethető vissza, hogy a távgyógyászat kezdetleges alkalmazása általában olyan országokhoz köthetö, amelyek nagykiterjedésűek (pl. USA) és ezáltal a térnek, valamint a távolságnak különösen meghatározó szerepe van. Másrészt a természeti környezet és az időjárási viszontagságok (pl. skandináv országok) is komoly akadályát képezhetik az ellátásnak (KovÁcs Z. 2010).

Ráadásul előfordulnak olyan helyzetek - mint például a természeti katasztrófák, háborúk, tengeri utak, légi járatok, vagy akár az ürutazás -, melyek során sok esetben nincs lehetőség bonyolult orvosi vizsgálatokra, illetve szükség esetén beavatkozásokra, ezért az ellátás elérhetőségét ezekben a szituációkban a telemedicina és az infokommunikációs technológiák teremthetik meg, függetlenül attól, hogy a tér mely pontján igénylik azt (CRAIG, J. PATTERSON, V. 2005).

A telemedicina történetét alapvetően meghatározza definíciójának értelmezése. A mai értelemben vett távgyógyászat csak az elmúlt évtizedek terméke, ami visszavezethető az infokommunikációs technológiák fejlődésére. Amennyiben azonban a telemedicina fogalmának tágabb értelmezése a mérvadó, amibe beletartozik minden egészségügyi tevékenység távoli alkalmazása, akkor a története jóval hosszabb idöre nyúlik vissza (CRAIG, J. - PATTERSON, V. 2005, TÖRÖK M. et al. 2007).

Egy korai példája már a 18. században megjelent, amikor Nagy-Britanniában a postai szolgáltatásoknak köszönhetően a diagnózis meghatározásához vizeletmintákat küldtek egyes háziorvosok (TöRÖK M. et al. 2007). 
Ezt követően a 19. század közepétől a távíró forradalmasította az ellátás egyes területeit és lehetőséget adott az orvosi információk nagy távolságokra történő továbbítására. A telegráfot alkalmazták az amerikai polgárháborúban, illetve 1874-ben Ausztráliában is a sebesülteknél tanácsadás céljából (BAshshur, R.L. - Shannon, G.W. 2009, Craig, J. - PATterson, V. 2005, DARAGÓ L. et al. 2013, MARS, M. 2013).

A következő technikai vívmány, a telefon, még meghatározóbb szerepet kapott a távgyógyászatban, mint a távíró. Ez ugyanis évtizedekig az orvosi távolsági kommunikáció fő eszköze volt. A telefonos konzultáció legkorábbi példája már 1879-ben megvalósult, de az első, telefonhálózaton keresztül küldött EKG jel, ami Einthoven nevéhez köthető, csak 1905ben realizálódott (BASHSHUR, R.L. - ShannON, G.W. 2009, CRAIG, J. - PATTERSON, V. 2005, MARS, M. 2013, TÖRÖK M. et al. 2007, ZunDEL, K. M. 1996).

A telefonon kívül a rádiós kommunikációt is sikerült az ellátásban hasznosítani, melynek keretében 1920-ban az ún. „Seamen's Church Institute of New York” az elsők között nyújtott orvosi támogatást (távkonzílium) a tengeren utazóknak. Ugyancsak ebben az évben kezdték alkalmazni a rádiós konzultációt Norvégiában (Haukeland kórház), majd később Franciaországban és Olaszországban is bevett gyakorlat lett a 20. század első néhány évtizedében (Bashshur, R.L. - Shannon, G.W. 2009, Craig, J. - PAtTerson, V. 2005, DARAGÓ L. et al. 2013).

A modern telemedicina kialakulásában több tényező is meghatározó szerepet játszott. Mindenekelőtt az infokommunikációs technológiák gyors fejlődése, a NASA ürrepülési programja nyomán indult kutatások (pl. távfelügyelet), illetve a magánszektor fejlesztései. Ebben a tekintetben meghatározóak a telemetriai fejlesztések, különösképpen az ürhajósok vitális paramétereinek Földről történő rendszeres monitorozása (BASHSHUR, R.L. - SHANNON, G.W. 2009, Bashshur, R.L. - Reardon, T.G. - Shannon, G.W. 2000, Craig, J. PATTERSON, V. 2005, ZUNDEL, K. M. 1996).

A távgyógyászatban nagy áttörést jelentettek az 1950-es évek végén a zárt láncú televízió és video kommunikációs fejlesztések. Ebben az időszakban (1957) valósult meg a teleradiológia egyik korai példája Montrealban, amikor röntgen képeket továbbítottak a városban két kórház között. Jóllehet radiológiai képek küldésére már az 1950-es évek elején is voltak példák az Egyesült Államokban (BASHSHUR, R.L. - SHANNON, G.W. 2009, BASHSHUR, R.L. - Reardon, T.G. - Shannon, G.W. 2000, Craig, J. - Patterson, V. 2005, Gombás P. et al. 2004, GombÁs P. - SzEnde B. - Stotz Gy. 2000, TöRÖK M. et al. 2007, Zundel, K. M. 1996).

A zártláncú fejlesztések további gyakorlati alkalmazására került sor 1964-ben (noha a kísérletek az 1950-es években megkezdődtek), a norfolki kórház és a Nebraska Pszichiátriai Intézet között, ami jelentős távolságot, 112 mérföldet jelentett és a telepszichiátria kezdetét jelezte. Ez lényegében pszichiáterek és háziorvosok közötti távkonzultációt jelölt, ami nem csupán a gyógyítást szolgálta, hanem az oktatást is (BASHSHUR, R.L. - SHANNON, G.W. 2009, BAshshur, R.L. - ReArdon, T.G. - Shannon, G.W. 2000, Craig, J. - PATterson, V. 2005, DAragó L. et al. 2013, GombÁs P. et al. 2004, GombÁs P. - Szende B. - Stotz Gy. 1996, 2000, MARS, M. 2013, Zundel, K. M. 1996).

Néhány évvel később, 1967-ben (egyes irodalmi források szerint 1968-ban) egy újabb audiovizuális kapcsolat, immár teljes körü telemedicinális rendszer létesítésére (mikrohullám segítségével) került sor a Boston Logan Nemzetközi Repülőtér és a Massachusetts-i Általános Kórház között. Ez lehetőséget adott az utasok és a repülőtéri alkalmazottak ellátására is, melyet ápolók végeztek, de távoli orvosi tanácsra. Ennek a telemedicinális szolgáltatásnak a relevanciáját az is mutatta, hogy több mint ezer beteget láttak el a projekt első éveiben (BASHSHUR, R.L. - SHANNON, G.W. 2009, BASHSHUR, R.L. - REARDON, T.G. - SHANNON, 
G.W. 2000, Craig, J. - Patterson, V. 2005, Zundel, K. M. 1996). Egyes kutatók szerint a két hely között már kezdetleges telepatológiai szolgáltatás is történt (BASHSHUR, R.L. Shannon, G.W. 2009, GombÁs P. - Szende B. - Stotz Gy. 1996).

A nőgyógyászatban használt telemedicinális lehetőségek kihasználása később, az 1980-as években kezdődött az Amerikai Egyesült Államokban és Magyarországon egyaránt, amikor a méhaktivitás monitorozása állt a kutatás középpontjában. Ennek eredményeként csökkenthetővé vált a méhen belüli halálozások száma (TöRÖK M. et al. 2007).

A telepatológiai szolgáltatás egyik korai, meghatározó példája szintén az 1980-as évek közepére tehető Bostonban, ugyanakkor az 1990-es évekre Európában is sor került telepatológiai rendszerek kiépítésére (pl. Tromsø - Kirkenes között). Néhány évvel később, 1995-ben Magyarországon is elkezdődtek a telepatológiai kísérletek (BM Kórház és a SOTE között) (GomBÁs P. et al. 2004, GomBÁs P. - SzEnde B. - Stotz Gy. 1996, 2000).

A telesebészet „hajnalát” az első robot asszisztált epehólyag mütét jelezte Belgiumban, 1997-ben (HAideGGer T. 2010, HozNEK A. 2008, SÁNDOR J. et al. 2001).

Ennek ellenére az első nagy távolságot áthidaló tényleges távmanipulációra csak 2001-ben került sor, amikor a sebész New Yorkban, míg a beteg Strasbourgban tartózkodott. Ez szintén epehólyag mütét volt és „Lindbergh operáció” néven vált ismerté (DARAGÓ L. et al. 2013, FICZERE A. 2012a, HAIDEGGER T. 2010, HoZNEK A. 2008).

Jelenleg a telemedicina számos típusát alkalmazzák a világ egyes országaiban, kihasználva annak „távolságcsökkentő” szerepét, ami az infokommunikációs technológiák hatásaiból eredeztethető (WHO 2010). Ebböl adódóan célszerü a távgyógyászat térbeli-földrajzi vonatkozásainak vizsgálata, aminek első lépése lehet az információs és kommunikációs technológiák hatásainak számbavétele.

\subsection{Az infokommunikációs technológiák téralakító hatása}

A telemedicina egészségföldrajzi aspektusait megelőzően érdemes röviden megvizsgálni az infokommunikációs technológiák térbeli vonatkozásait, illetve a térre és távolságra gyakorolt hatásait. Tekintettel a telemedicina informatikai aspektusaira, és az IKT ellátásban jelentkező integrációjára, ennek az ellátási formának a hatásai sokszor hasonlóak e technológiákéhoz. Ezek az elmúlt évtizedekhez köthetők, ugyanis az 1970-es évek óta mind a szállítási, mind pedig a kommunikációs költségek jelentősen csökkennek, ami többek között visszavezethető az információs és kommunikációs technológiák robbanásszerü fejlődésére, amely az ún. ötödik Kondratyev-ciklus jellegzetességeként identifikálható (CASTELLS, M. 2005, Dicken, P. 2011, HARVEY, D. 1989).

Ebben az ötödik szakaszban a globális gazdaság egyik hajtóerejévé az információs és kommunikációs technológiák válnak, hiszen részben ezek szolgáltatják a szükséges infrastrukturális elemeket. Mind a közlekedési, mind pedig a kommunikációs technológiák ún. „cirkulációs” folyamatként értelmezhetők, amelyek a társadalmi-gazdasági élet müködéséhez elengedhetetlenek. Ezek nem csupán a globális gazdaságban éreztetik a hatásukat, hanem a társadalmi kapcsolatok, társas interakciók ápolásában is (CASTELLS, M. 2005, Dicken, P. 2011, DudÁs G. 2013, Graham, S. 1998, MészÁros R. 2010a, Nagy G. 2003, 2010, RAKONCZAI J. 2008, TINER T. 2004).

A fejlődés eredményeként nagymennyiségü információt lehet gyorsan feldolgozni, viszonylag egyszerüen tárolni, és a másodperc töredéke alatt továbbítani a világ egyik részéből a másikba. Ennek a gyors és nagyléptékü modernizációnak köszönhetően egyfajta hatalmi forrásként jelennek meg az infokommunikációs technológiák, amelyek relevanciája tovább növekszik (DiCKEN, P. 2011, GRAHAM, S. 1998). 
A digitalizációs és globalizációs folyamat felgyorsulása miatt többek a távolság és a földrajz halálát vizionálják, amit a transznacionális vállalatok piaci növekedése is alátámaszt, hiszen e vállalatok tevékenységüket határokon átnyúlva végzik (MORGAN, K. 2001). Az ún. tér-idő „tömörítésnek” köszönhetően a tér idő általi „,megsemmisülése” is sokat hangoztatott gondolatként jelenik meg (HARVEY, D. 1989, MorGAN, K. 2001). Eszerint a társadalom és gazdaság számára a földrajzi távolság többé nem jelent akadályt (GRAHAM, S. 1998). Az egykori hely-specifikus tevékenységek és szolgáltatások bárhol végezhetők és nyújthatók a Földön. Így az információ és a tudás áramlását akadályozó tényezők is megszűnnek. E nézet szerint a fizikai távolságot a szervezeti közelség is helyettesítheti (MORGAN, K. 2001).

Az előzőekkel ellentétben megjelenik egy másik teória is, ami a földrajznak továbbra is fontos szerepet tulajdonít, és amely szerint a távolság és a földrajz „halálát” hirdető elméletek a valós világ tényleges társadalmi-gazdasági folyamatait rendkívüli módon leegyszerüsítik (JАKOBI Á. 2007). A térbeli korlátok oldódása automatikusan nem jelenti a tér jelentőségének redukálását, hiszen a tér ma is hordoz differenciákat (pl. erőforrások, infrastrukturális ellátottság mentén) magában, ami meghatározó a globális gazdaságban (CASTELLS, M. 2005, ERDősi F. 2003, GrAHAM, S. 1998, HARVEY, D. 1989, NAGY G. 2003, 2010).

Azok az infrastrukturális elemek, amelyek előfeltételei az infokommunikációs technológiák müködésének egyenlötlenül oszlanak meg a térben. Ezek meghatározzák a kapcsolat milyenségét, ezáltal lesznek jól és kevésbé jól bekapcsolódott térségek (JAKOBI Á. 2007). Az IKT által generált virtuális tér ugyanis alapvetően a nagyvárosokhoz kapcsolódik, melynek köszönhetően a globális városok továbbra is megerősítik a dominanciájukat. A területi egyenlötlenség mellett pedig megjelenik a társadalmi egyenlötlenség is, hiszen egyes társadalmi csoportok kiszorulnak e technológiák használatából (GRAHAM, S. 1998, HARVEY, D. 1989, JAKOBi Á. 2007, MészÁros R. 2001, 2008, 2010b).

A fejlett országok és az urbánus térségek, továbbá a fejlődő országok és a rurális térségek jól elkülöníthetők az információs társadalom jegyei alapján, hiszen ennek előfeltételei az utóbbi országok és térségek esetében a mai napig hiányosak (pl. megfelelő infrastruktúra és szükséges jövedelem stb.). Mivel nincsenek birtokukban a nélkülözhetetlen erőforrások, amelyek előfeltételei és mozgatórugói a társadalmi-gazdasági fejlődésnek, így egyre inkább leszakadnak a fejlett térségektől és ennek köszönhetően létrejön az ún. „digitális szakadék”. Így lesznek tehát olyan térségek, akik élvezhetik az infokommunikációs technológiák jótékony hatásait (beleértve az elektronikus egészségügyi szolgáltatásokat), és lesznek olyanok is, akik kirekesztődnek belőle (DZENOWAGIS, J. 2009).

A földrajz szerepét erősíti az is, hogy az infokommunikációs technológiák által támogatott virtuális tér feltehetően sohasem lesz képes helyettesíteni a fizikai teret, hiszen a verbális kommunikáció mellett a non verbális is meghatározó. A face to face interakció, a fizikai közelség, a társadalmi kölcsönösség alapvető feltételei a társadalmi életnek és a gazdaság müködésének (GRAHAM, S. 1998, MORGAN, K. 2001).

Bár a kodifikált tudás az infokommunikációs technológiákon keresztül viszonylag egyszerüen terjeszthető, ez nem igaz a tacit tudásra. A kontextus függő folyamatok és innovációk esetében szintén szükséges a fizikai közelség, mivel egyes tényezők csak adott földrajzi környezetben adhatók át, illetve szerezhetők meg (MORGAN, K. 2001).

Ebből adódóan az infokommunikációs technológiák az emberi interakciókban csupán kiegészítő szerepet töltenek be és soha sem helyettesítöt. A fizikai teret és a virtuális teret célszerü együtt kezelni, hiszen ezek összetett módon kapcsolódnak egymáshoz, és nem különálló világok. A földrajzi helyeket és tereket részben az infokommunikációs technológiák kapcsolják össze. Az átjárhatóság a fizikai világból a virtuálisba az ún. „belépési pontokon” 
keresztül történik, amelyek konkrét földrajzi koordinátákkal rendelkeznek (GRAHAM, S. 1998, JAKOBI Á. 2007, MoRGAN, K. 2001, MÉSZÁROS R. 2001, 2008, 2010b).

Összességében tehát a földrajz jelentőségét hangsúlyozó nézetek szerint az információs és kommunikációs technológiák átértékelik a távolság fogalmát, azonban ez a folyamat nem azonosítható a távolság értéktelenedésével, vagy szerepének megszünésével. A földrajzi teret célszerü kapcsolati térként kezelni, melyben az elérhetőségnek és a hozzáférhetőségnek van jelentősége, az elérhetőség esetében az elérési időnek, a hozzáférhetőség tekintetében pedig a hozzáférési (belépési) ponttól vett fizikai távolságnak (BÁN A. 2014a, Boros L. 2010a, JAKOBi Á. 2007, MÉszÁros R. 2001, 2008, 2010a, 2010b, Morgan, K. 2001, NAGY G. 2003, 2010).

Az előzőekben ismertetett tényezők, többek között a távolság átértékelődése, a fizikai és virtuális világ kapcsolata, a face to face interakciók, vagy azok hiánya, a térbeli és társadalmi egyenlőtlenség kérdése, az elérhetőség és hozzáférhetőség megjelenik minden infokommunikációs technológiával támogatott szolgáltatásnál, így a telemedicinánál is (BÁN A. 2015). A távgyógyászat egészségügyügyi ellátásra gyakorolt hatásai (pl. elérhetőség javítása) pedig koherensek az egészségföldrajz kérdéseivel.

\subsection{A telemedicina egészségföldrajzi vonatkozásai}

Tekintettel a telemedicina egészségügyi és térbeli vonatkozásaira, leginkább az egészségföldrajzzal hozható összefüggésbe a geográfián belül. Ennek az oka pedig az, hogy az egészségföldrajz olyan multidiszciplináris terület, amely többek között azokkal a tudományterületekkel áll kapcsolatba, amelyek a telemedicinát is determinálják. Az egészségföldrajz lényegében egyike a társadalomföldrajzhoz tartozó tudományszakágaknak, ami az egészségi állapot és az egészségügyi ellátórendszer térbeli jellegzetességeivel foglalkozik. Sajátossága, hogy számos tudományterület módszerére és eredményére épít, így érinti többek közt az orvostudományt, a szociológiát, a demográfiát, a statisztikát, a közgazdaságtant, az informatikát stb. (PÁL V. 2002, 2005, 2010, PÁL V. - TóTH J. 2007).

A telemedicina, mint egészségügyi szolgáltatás a fenti területek többségével pedig összefüggésbe hozható. Nyilván a távgyógyászatot az orvostudomány alkalmazza, de szoros kapcsolat köti az informatikához is. Az előbbit az igazolja, hogy az egészségügy számos területén alkalmazzák az ellátás biztosítása, illetve javítása érdekében. Az utóbbi létjogosultságát pedig az adja, hogy a telemedicinális szolgáltatások müködéséhez, illetve müködtetéséhez szükséges alapinfrastruktúra (hardverek és szoftverek stb.) az informatikához kapcsolódik.

A telemedicina az előzőeken túl kisebb-nagyobb mértékben a szociológiához és a közgazdaságtanhoz is köthető. A szociológián belül elsősorban az egészségszociológia területe az, amivel kapcsolatba hozható. Egyrészt a telemedicina esetében különösen meghatározó az orvos-beteg, vagy éppen az egészségügyi szakemberek (orvos-orvos, orvosasszisztens) közötti viszony átalakulása és ennek vizsgálata. Másrészt további lényeges kérdés a telemedicina egészségügyi egyenlőtlenségekre gyakorolt hatásának az elemzése. Ráadásul a távgyógyászat számos szociológiai elmélettel is kapcsolatba hozható (pl. cselekvőhálózat

elmélet (LAW, J. 1992), strukturációs elmélet (GIDDENS, A. 1984)), amelyek különböző léptékekben magyarázhatják a telemedicina alkalmazását. A közgazdaságtanon belül leginkább az egészség-gazdaságtannal áll kapcsolatban a telemedicina, ami visszavezethető arra, hogy ez egy innovációként fogható fel, ami hozzájárulhat az ellátás hatékonyságának növekedéséhez, különösen tekintettel a költséghatékonyságra (FICZERE A. 2010a, PÁL V. 2002). 
A telemedicina az egészségföldrajz alapkérdései közül elsősorban az innovációk térbeli diffúziójához köthető (PÁL V. 2002, 2005, 2010, PÁL V. - TóTH J. 2007). Ezen belül nem csupán a földrajzi térben való és különböző időben történő megjelenés vizsgálata a lényeges, hanem az ok-okozati tényezők feltárása, amelyek hozzájárulnak a telemedicina alkalmazásához egyes területeken és intézményekben.

Az egészségföldrajz két fő területe (orvosföldrajz, egészségügyi földrajz) közül a telemedicina leginkább az utóbbihoz köthető. Ennek elsősorban három fő témakörét érinti: az erőforrás allokációt, az ellátás hozzáférhetöségét, és a tervezést. E kérdéskörök és ezek (egészségföldrajzi) vizsgálata is szorosan kapcsolódnak egymáshoz (PÁL V. 2002, 2005, 2010, PÁL V. - TóTH J. 2007).

A telemedicina lényegében az egyes egészségügyi erőforrások (pl. orvosok) térbeli eloszlásának a különbségeit (pl. orvoshiány) hivatott csökkenteni. Az egészségügyi egyenlőtlenségek kérdése különösen meghatározó a telemedicina esetében, és ez az, ami leginkább az egészségföldrajzhoz köti. Ugyanis a hatékonyság növekedése, amit a távgyógyászat - az infokommunikációs technológiáknak köszönhetően - generál, az a forráshiányos térségekben is kamatoztatható. Lényegében javulhat az ellátás elérhetősége és hozzáférhetősége a fizikai távolságtól függetlenül. A távgyógyászat hozzájárul a gyorsabb ellátáshoz, és segíti annak széles körben való igénybevételének lehetőségét (FICZERE A. 2010a, 2010b).

Összességében tehát a telemedicina az egészségügyi szükségletek és a mögöttes társadalmi-gazdasági korlátok térbeli megnyilvánulásának a kiegyensúlyozására törekszik. Az egyenlőtlenség kérdéséhez kapcsolható a tervezhetőség is. A telemedicina a különböző egészségügyi erőforrások térbeli tervezésénél a humánerőforrás allokációjának hiányosságait segíti kiküszöbölni, ezáltal megteremtve a biztonságos ellátást különösen azokban a térségekben, ahol ez másként nem lehetséges, vagyis ahol a távgyógyászatnak nincs alternatívája (FICZERE A. 2010a).

Természetesen a telemedicina az egészségügyi földrajzon belül nem csak a fenti témakörökkel hozható kapcsolatba, hanem a nemzetközi egészségföldrajz néhány új kutatási irányzatával is. Ezek közé tartozik többek között az ápolás egészségföldrajza és a földrajzi gerontológia, amelyek az idősek (és az ápolók) térhasználatával és egészségi állapotával foglalkoznak (ANDrews, G.J. 2006, ANDrEws, G.J. et al. 2007, BÁN A. 2013a, PÁL V. 2009, PÁl V. - Boros L. 2013).

A telemedicina egyik részterülete, a távfelügyelet lehetőséget teremt a különböző vitális paraméterek (pl. vérnyomás, vércukor, véroxigén stb.) távoli ellenőrzésére [3] (FICZERE A. 2010a, 2010b, FICZERE A. - KÖDMÖN J. 2011). Az idős és/vagy ápolásra szoruló emberek esetében - lakóhelytől függetlenül (legyen az saját lakás, vagy bentlakásos otthon) meghatározó szerepet kaphat az életfunkciók folyamatos és távolból történő monitorozása az egészségi állapotuknak megfelelően, amihez a telemedicina biztosítja az alapot (NMRC 2007).

Összességében tehát a távgyógyászat az egészségföldrajz kutatási témaköreihez és irányzataihoz több szálon kötődő, annak számos segéd- és társdiszciplínájával kapcsolatba hozható és ebböl adódóan multidiszciplináris megközelítést igénylő terület. Az egészségföldrajz kutatási területei közül is kiemelendő a telemedicinának az ellátás elérhetőségével és az egészségügyi erőforrások területi egyenlőtlenségeivel való kapcsolata. Ebből adódóan célszerü röviden áttekinteni a távgyógyászat és az egészségügyi ellátás területi differenciáinak viszonyát, a telemedicina egyenlőtlenségekre gyakorolt esetleges hatásait. 


\section{A telemedicina és az egészségügyi egyenlötlenségek}

\subsection{A hazai egészségügyi egyenlőtlenségek általános területi folyamatai}

Tekintettel arra, hogy az egészségügyi erőforrások területi differenciái az ellátás biztosítását, a hozzáférhetőséget megnehezítik, és így az esélyegyenlőséget csökkentik, egyes feltételezések szerint ennek mérséklésének egyik eszköze lehet a távgyógyászat (WOOTTON, R. et al. 2012). A telemedicina egészségügyi egyenlötlenségekre gyakorolt pozitív és esetleges negatív hatásainak számbavételét megelőzően azonban érdemes röviden elemezni a hazai egyenlötlenségi folyamatokat és bemutatni azok térbeli mintázatát.

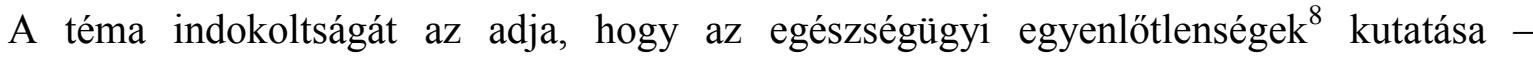
relevanciájából adódóan - egyre inkább előtérbe kerül, ugyanis számos hazai, több esetben empirikus kutatás igazolja az egészségi állapot és az egészségügyi ellátás területi differenciáinak meglétét (PÁL V. 2012, 2013, PÁL V. - Tóth J. 2007, UzzOLI A. 2009, Uzzoli A. et al. 2011, Uzzoli A. - SzilÁgyi D. 2013, SzilÁgyi D. - Uzzoli A. 2013, Vitrai J. et al. 2008, 2011).

Az egészségügyi egyenlőtlenség tartalmának tekintetében igen sok megközelítés létezik az egyes vizsgálatokban. Legáltalánosabban az egészségi állapotban jelentkező területi különbségként értelmezhető, de az egészségügyi erőforrások allokációjának, az ellátás elérhetőségének, hozzáférhetőségének és igénybevételének térbeli differenciájaként is interpretálható (OROSZ É. 2001).

$\mathrm{Az}$ egészségügyi ellátórendszert érintő területi különbségek az alapellátás szintjén is megfigyelhetők (3. ábra).

3. ábra: A háziorvosi szolgálat megléte településenként 2014-ben

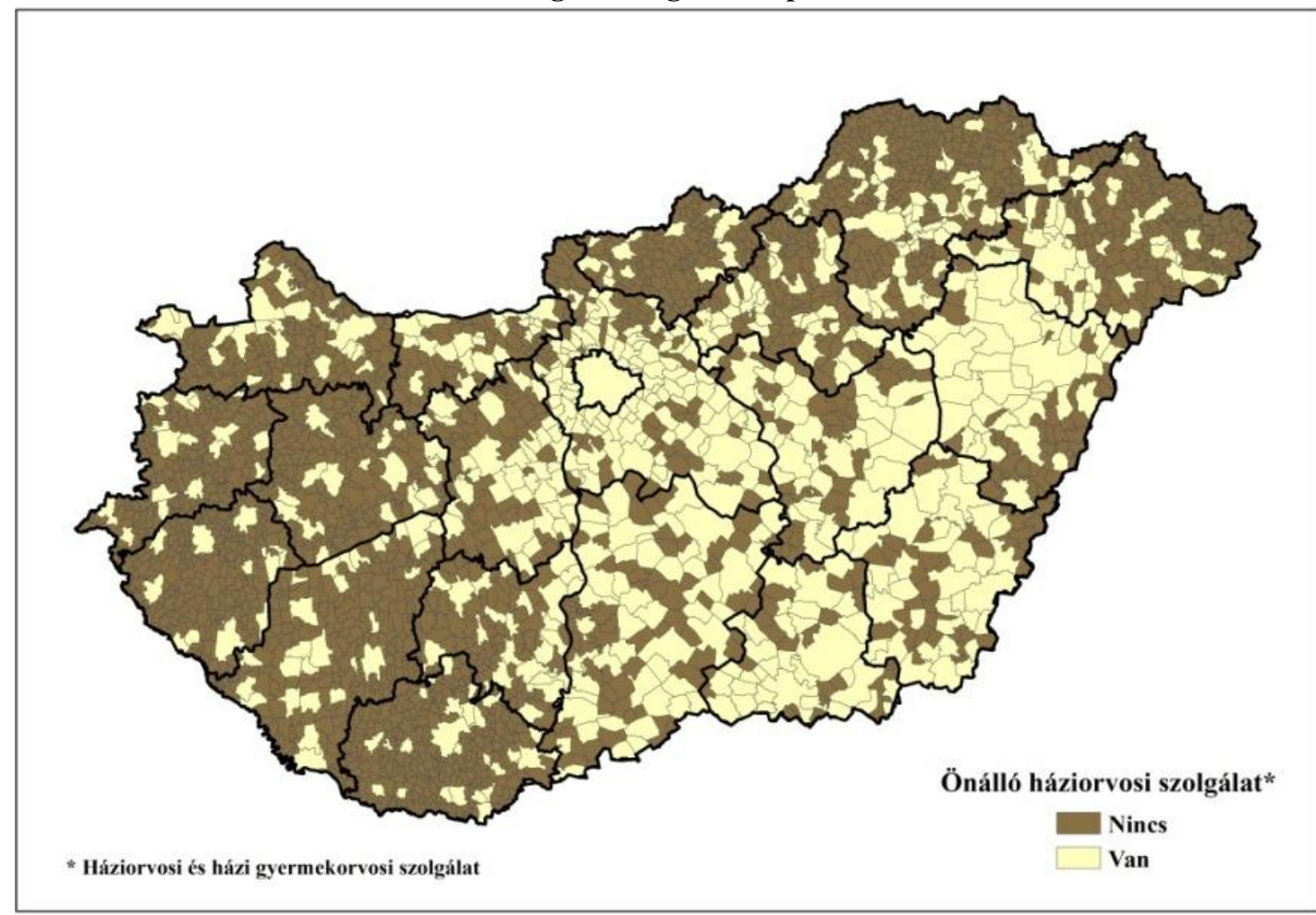

(Forrás: KSH T-STAR, szerk.: Bán A. 2016)

\footnotetext{
${ }^{8}$ Noha az egészségügyi egyenlőtlenségek részét képezik az egészségegyenlötlenségeknek (health inequity) (MEADE, M.S. - EMCH, M. 2010), ennek ellenére a disszertációban az előbbi terminust használom, ugyanis a telemedicina mindenekelött az egészségügyi rendszerben jelentkező területi különbségeket hivatott csökkenteni.
} 
Ezt mindenekelőtt az bizonyítja, hogy Magyarország több mint 3000 településének közel fele nem rendelkezik önálló háziorvosi praxissal, ami elsősorban a fenntarthatósággal és a humánerőforrás deficittel magyarázható. Mindenekelőtt az 500 fő alatti, vagyis az aprófalvas települések esetében jelenik meg ez a hiátus, ugyanakkor a 2000 fő felettiek tekintetében csak elvétve található önálló családorvossal nem rendelkező település. A háziorvosi szolgálat hiánya - legyen szó felnőtt vagy gyermek ellátásról - elsősorban a Dél-Dunántúl, NyugatDunántúl és Észak-Magyarország, zömében kis- és aprófalvas településeit érinti (KovÁCs P. PIRISI G. - TRÓCSÁNYI A. 2013).

Természetesen a települések lélekszáma alapvetően determinálja az önálló háziorvosi praxisok meglétét, így annak fenntarthatósága egy bizonyos népességszám alatt nem lehetséges. Ebböl adódóan a fenti ábrával mindössze a területi különbségekre kívánok fókuszálni. Az önálló praxis hiánya azonban azt is jelenti, hogy egy meghatározott rendelési időben csak egy helyen praktizálhat a háziorvos, így adott - önálló háziorvosi szolgálattal nem rendelkező - településen a mindennapi elérhetősége korlátozott.

Az Alföld területe a településhálózati sajátosságokból (általában nagykiterjedésű és lélekszámú települések) is fakadóan jóval kevésbé érintett, bár az önálló praxis hiánya mozaikszerüen a Duna-Tisza közén, a Közép-Tiszavidéken, továbbá Hajdú-Bihar megye határmenti, periferikus településein is előfordul. Ezt a helyzetet tovább árnyalja a tartósan betöltetlen háziorvosi praxisok területi mintázata is. Ugyanis ebben a tekintetben az Alföldön, különösen annak középső részein és Észak-Magyarországon igen meghatározó az ide tartozó háziorvosi körzetek száma (4. ábra).

\section{4. ábra: A tartósan betöltetlen háziorvosi praxisok területi megoszlása kistérségenként (2016. április)}

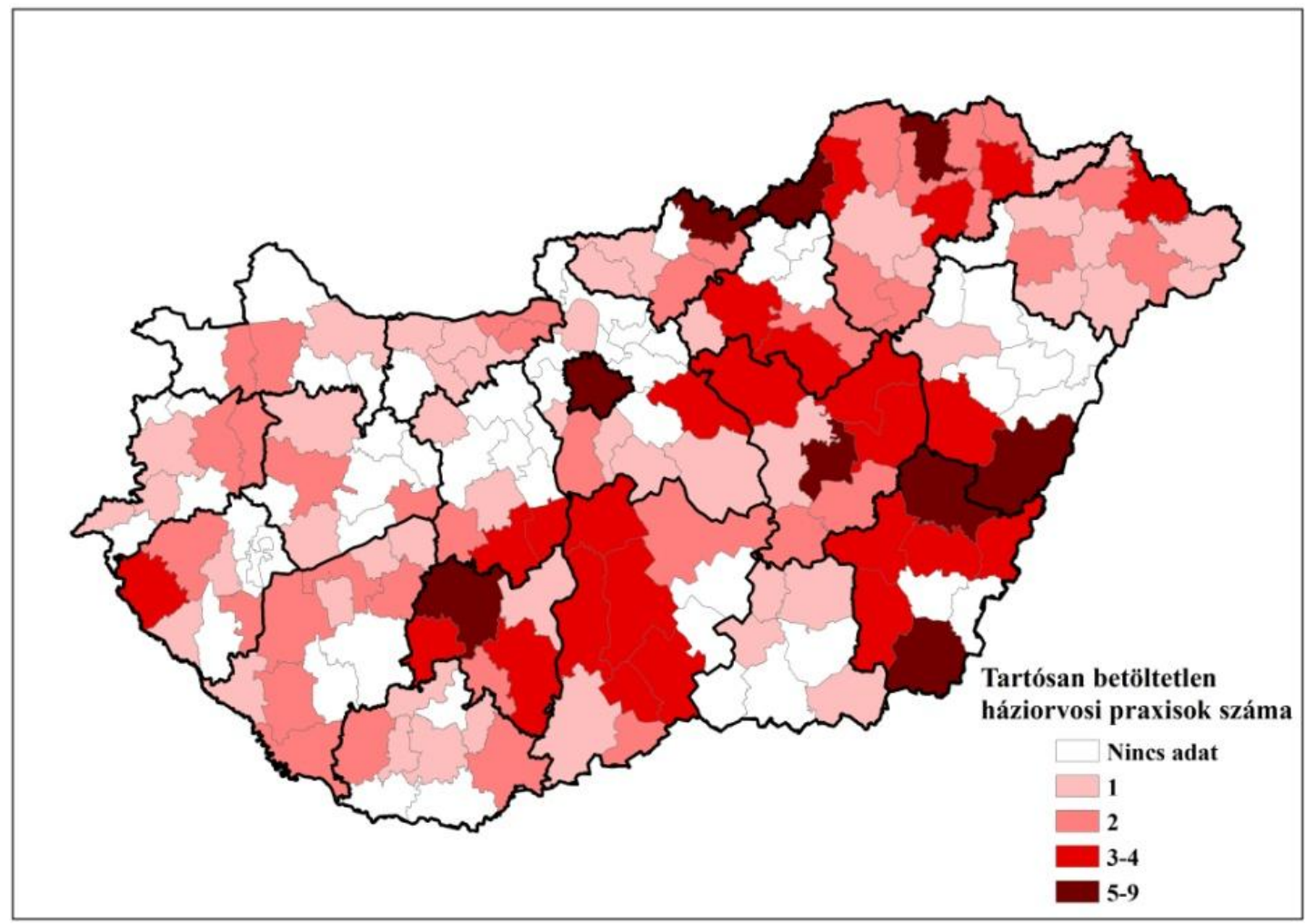

(Forrás: OALI, szerk.: Bán A. 2016)

Az egészségügyi ellátásban jelentkező egyenlőtlenségek természetesen nem csak az alapellátás esetében, hanem a magasabb progresszivitási szinteken is megmutatkoznak. Ezt mi sem bizonyítja jobban, mint az Európai lakossági egészségfelmérés (ELEF) eredménye, 
miszerint Magyarországon a válaszadók (5826 fö) saját értékelése szerint $13 \%$-uk nem kap időben ellátást, vagy abszolút nélkülözi azt, amiben szerepet játszik az adott egészségügyi intézmény elérhetősége is (KSH 2015).

A föváros ellátás tekintetében tapasztalható központi szerepe jóllehet jelentősen redukálódott az elmúlt években, Budapest primátusa ma is megkérdőjelezhetetlen (KISS J.P. 2013, Orosz É. 2001). Ezenkívül meghatározó még a vidéki klinikák (Debrecen, Pécs, Szeged), illetve néhány nagyobb megyei kórház ellátásban betöltött funkciója is. A fekvőbetegek ellátásának a lebonyolítása túlnyomó többségben $(90 \%)$ pedig mindössze 45 településhez köthető, ami szintén a térbeli koncentrációra hívja fel a figyelmet (KISS J.P. 2013). Egy másik tanulmány szerint is a kórházi betegellátás jelentős része néhány magas progresszivitási szintü, kulcsintézményhez kapcsolódik (PÁL V. - KISS J.P. - TIPEI, A. 2006).

Az ezer lakosra jutó kórházi ágyak száma, ami az egészségügyi erőforrások egyik meghatározó indikátora, szintén a fentieket erősíti meg (5. ábra). A fővárost nem számítva Pest megye rendelkezik a legkedvezőtlenebb értékkel. Míg a Nyugat-Dunántúl régió, illetve Baranya, Veszprém, Csongrád és Nógrád megyék (illetve azok kistérségeinek) mutatói meghatározók. Ezek többségében, a társadalmi-gazdasági fejlettség tekintetében viszonylag kedvező területei az országnak. Ugyanakkor azok a térségek, amelyeknek leginkább szükségük lenne az egészségügyi erőforrásokra, általában nem tartoznak a nyertesek közé, vagyis a szükséglet és az igény, a méltányos eloszlás nem minden esetben találkozik (OROSZ É. 2001).

5. ábra: Az ezer lakosra jutó kórházi ágyak területi megoszlása kistérségenként 2014-ben

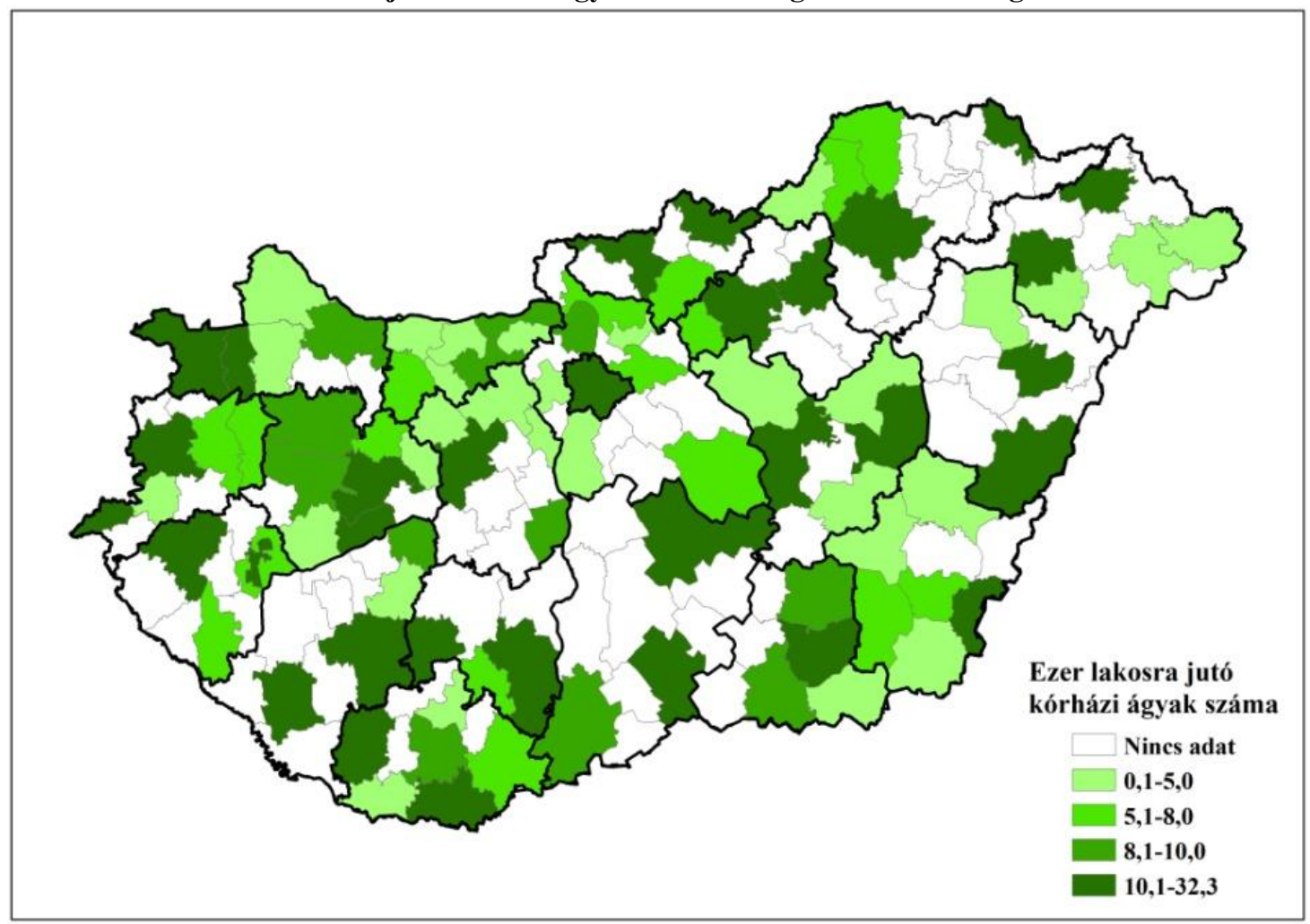

(Forrás: KSH T-STAR, szerk.: Bán A. 2016)

Szintén az egyenlőtlenségre utal a kórházak elérhetősége. KISS J.P. (2013) vizsgálata szerint az aktív ellátást biztosító kórházak időbeli elérhetősége azt mutatja, hogy az ország településeinek közel négyötödéről fél órán belül elérhető egy kórház. A legjobb elérhetőség szorosan kötődik a gyorsforgalmi utak és autópályák meglétéhez és azok közelségéhez. A 
szerző modelljében arra is felhívja a figyelmet, hogy vannak olyan térségek, ahol ez csak jelentős időtúllépés árán lehetséges, és ezekben az esetekben ez elérheti, és meg is haladhatja az egy órát. Ebben a tekintetben az ország legnyugatibb határmenti része, Tolna és Somogy megye egyes területei, a Közép-Tiszavidék, illetve Borsod-Abaúj-Zemplén megye középső és északi részei érintettek a leginkább (KISS J.P. 2013).

Az ellátás elérhetőségének és hozzáférhetőségének egyenlőtlenségeit egy, a szürkehályog beavatkozásokat érintő kutatás is megerősíti (UzzOLI A. et al. 2011, VITRAI J. et al. 2011). Egyrészt megfigyelhető egy erős koncentrációs folyamat, ugyanis a mütétek többségét az erre szakosodott intézményeknek viszonylag kis hányada végzi el. Másrészt a betegek lakóhelyének meghatározó szerepe van az ellátás hozzáférhetőségének tekintetében. Ennek alapján a szürkehályog beavatkozásokat a páciensek jelentős része a lakóhelyüktől eltérően, más településen veszi igénybe. Ráadásul az érintettek aránya a lokális lépték felé haladva fokozatosan növekszik (UzzoLI A. et al. 2011, VITRAI J. et al. 2011).

Az egyenlőtlenség egy másik típusa az egészségi állapotban jelentkező területi differencia. Noha az egészségi állapotot alapvetően több tényező is behatárolja - úgymint a genetika, az életmód, az egészségügyi ellátórendszer, a lakó- és munkakörnyezet, az iskolázottság, a jövedelem, a társadalmi státusz stb. -, ezek egy része az egyén lehetőségeitől, választásától függetlenül is él, ami az egyenlőtlenséget erősíti (Orosz É. 2001, PÁL V. - TóTH J. 2007, PÁL V. - Uzzoli A. 2013, UzZOLI A. - SziLÁGyi D. 2013, Vitrai J. et al. 2008).

Egyes szerzők arra is rámutatnak, hogy az egészségi állapot területi differenciáinál meghatározó szerepe van a társadalmi-gazdasági fejlettségnek (OrOsz É. 2001, PÁL V. 2012, 2013, PÁl V. - Tóth J. 2007, Uzzoli A. 2009, Uzzoli A. - SzilÁgyi D. 2013, Szilágyi D. UzZOLI A. 2013, Vitrai J. et al. 2008).

Az egyenlőtlenségek pedig nem csak nagyobb földrajzi léptékekben tapasztalhatók, hanem település-típusonként is érzékelhetők. Több kutatás igazolja, hogy a rurális településekben és térségekben jóval kedvezőtlenebb az ott élők egészségi állapota, mint az urbánus térségekben (MEAdE, M.S. - EMCH, M. 2010, PÁL V. 2012, 2013, PÁL V. - TóTH J. 2007).

Az egészségegyenlőtlenségek egyik legfontosabb indikátora a születéskor várható átlagos élettartam, ami sokat elárul az egészségi állapotról (UzzOLI A. 2009). A 2015-ös KSH adatok szerint a várható élettartam értékei a férfiak (73,86 év) tekintetében a fővárosban, míg a nők (79,70 év) esetében Győr-Moson-Sopron megyében a legmagasabb [4].

A férfiaknál Budapestet sorrendben Győr-Moson-Sopron, Pest, Zala és Veszprém megyék követik. Míg ezek ellenpólusaként Borsod-Abaúj-Zemplén (70,00 év) és KomáromEsztergom (70,33 év) megyék sereghajtóként szerepelnek. Az erősebbik nemhez tartozók esetében a legmagasabb és a legalacsonyabb érték között 3,86 év a különbség, vagyis a fővárosban átlagosan közel 4 évvel él tovább egy férfi, mint Borsod-Abaúj-Zemplén megyében [4].

A nők esetében a Győr-Moson-Sopron megyében tapasztalható értéket sorrendben Zala megye, Budapest, Vas és Hajdú-Bihar megyék közelítik meg, míg a másik oldalon, a legkedvezőtlenebb eredményeket Jász-Nagykun-Szolnok (76,87 év) és Komárom-Esztergom (77,26 év) megyék adják. Győr-Moson-Sopron és Jász-Nagykun-Szolnok megyék értékei között 2,83 év a differencia, tehát egy nő átlagosan ennyi idővel él tovább az ország északnyugati részében a legalacsonyabb értéket produkáló megyéhez képest [4].

Egyes kutatások is hasonló eredményröl számolnak be, amelyeknek végső kicsengése a Nyugat- és Kelet-Magyarország közötti dichotómia megléte (UzzoLI A. 2009, UzzoLI A. SZILÁGYi D. 2013, SZILÁGYi D. - UZZOLI A. 2013). 
UZZOLI A. - SzILÁGYi D. (2013) egyik munkájukban például a gazdasági válság hatására megerösödött munkanélküliség és a születéskor várható átlagos élettartam közötti összefüggést vizsgálják. Az eredmények szignifikáns együttmozgásról tanúskodnak a két mutató esetében, melynek megfelelően a magas munkanélküliség általában alacsony várható élettartammal társul. Továbbá arra is rávilágítanak, hogy időben előrehaladva egyre nagyobb az eltolódás a keleti, kedvezőtlenebb helyzetü térségek felé (UZzOLI A. - SzILÁGYI D. 2013, SZILÁGYi D. - UZZOLI A. 2013).

Összességében tehát az egészségügyi egyenlőtlenségek sokdimenziós jelenségként interpretálhatók, amelyeknek markáns területi mintázata is ismert. Azonban a telemedicina az egyenlőtlenség egyes típusaira, csakúgy, mint a területi differenciáira - a hazai és nemzetközi szakirodalom (pl. MATUsitz, J. - BREEN, G.M. 2007) szerint - érdemi választ ad.

\subsection{A telemedicina néhány egészségügyi egyenlőtlenséget csökkentő hatása}

Mint korábban már jeleztem, a szakirodalom szerint a távgyógyászat az egészségügyi egyenlőtlenségeket csökkentheti, elsősorban az infokommunikációs technológiák fejlődésének köszönhetően (MATUSITZ, J. - BREEN, G.M. 2007). A telemedicina egészségügyi rendszerekre - és általában az ellátásra - gyakorolt hatásai csak részben kvantifikálhatók (pl. ellátási költség), hiszen a távellátás minőségi változást is magában hordoz (pl. megbízható diagnózis), ami nehezen számszerüsíthető (BÁN A. 2015).

Noha a telemedicina kedvező hatásainak köszönhetően növelheti az ellátás hatékonyságát, ennek ellenére az egészségügy alapstruktúráját valószínűleg nem változtatja meg, sokkal inkább kiegészíti a betegek fizikai jelenléten alapuló ellátását, így azt vélhetően nem helyettesíti (BÁN A. 2015, DARKINS, A. et al. 2008).

A telemedicina jelentősége az egészségügyi szolgáltatás gyorsabb, egyszerübb elérhetőségében és hozzáférhetőségében, valamint a minőségi és a hatékony ellátásban mutatkozik meg (Craig, J. - PAtTerson, V. 2005, GAGnon, M.P. et al. 2006, LeVert, D. 2010, NYKÄNEN, P. 2006). Ebből adódik, hogy a telemedicina jó eszköz lehet az egészségügyi ellátásban jelentkező egyenlőtlenségek csökkentésére (BÁN A. - PÁL V. 2015, MATUSITZ, J. Breen, G.M. 2007, Wootton, R. et al. 2012), azonban egyesek szerint (lásd következő fejezet) újra is termelheti azokat.

A telemedicina területi egyenlőtlenségeket csökkentő szerepe elsődlegesen abban mutatkozik meg, hogy a központtól távoli, egészségügyi erőforrásokkal nem, vagy azokkal szűken rendelkező térségek számára is elméletileg biztosíthatja a megfelelő ellátást, illetve a szolgáltatáshoz való hozzáférést (FICZERE A. 2010a, GAGNON, M.P. et al. 2006).

Így olyan térségek lakói is magas szintű ellátásban részesülhetnek, ahol a földrajzi elérhetőség akadályt képez (pl. kiépítetlen vagy rossz állapotú közlekedési infrastruktúra). Ennek megfelelően a telemedicina minőségi ellátást biztosíthat a vidéki területeken élök számára, ahol az alapellátást nyújtó orvosok megsegítésére speciális esetekben az infokommunikációs technológián keresztül bekapcsolódhatnak szakorvosok is (BÁN A. 2015, GaGnON, M.P. et al. 2006, LeVERT, D. 2010).

A távellátás egyik gyakran említett térbeli előnye, hogy az egészségügyi szolgáltatás elérhetősége nagymértékben javul, és nem jár feltétlen fizikai helyváltoztatással, ugyanis nem az egészségügyi szereplök utaznak, hanem az (egészségügyi) adatok áramlanak. Ennek megfelelően az ellátás időmegtakarítással jár, aminek a csökkenő költségvonzata is lényeges, hiszen a munkaidő kiesés és a közlekedési költségek lényegében megszünhetnek. Az előzőeknek köszönhetően a várakozási listák jelentősen lerövidülhetnek, és redukálódhat az 
indokolatlan ellátás is. Mindezek következtében pedig a felesleges adminisztratív és improduktív munka is csökkenhet (BÁN A. 2015, FICZERE A. 2010a, FICZERE A. - KÖDMÖN J. 2011, Gagnon, M.P. et al. 2006, LeVert, D. 2010, Matusitz, J. - Breen, G.M. 2007, Strömgren, M. 2003, Wootton, R. - BAhaAdinbeigy, K. - Hailey, D. 2011).

Szintén előnyösek lehetnek a tágabban értelmezett telemedicinális, vagy e-egészségügyi szolgáltatások (pl. internetes egészségportálok) - egyre növekvő kereslettel -, amelyek az egyenlőtlenségek redukálása felé mutathatnak (MATUSITZ, J. - BREEN, G.M. 2007). Az internet ugyanis lehetőséget ad arra, hogy a betegek hozzáférjenek speciális egészségügyi információkhoz, amik elősegítik az egészségkultúrájuk szintjének emelkedését. A kapott egészséggel kapcsolatos tanácsok, valamint az elsajátított ismeret és tudás jótékonyan befolyásolhatja az internetes felhasználók egészségi állapotát (BÁN A. 2015, NYKÄNEN, P. 2006, Wickramasinghe, N. - Geisler, E. - SCHAFFER, J. 2006).

Egyes szerzők arról számolnak be, hogy az e-egészségügyi szolgáltatásokat feltehetően már milliós nagyságrendben veszi igénybe a felnőtt népesség. Ennek ellenére óriási potenciál található ebben az ágazatban, amit még a fejlett országok sem használnak ki kellően (Matusitz, J. - Breen, G.M. 2007, Wickramasinghe, N. - Geisler, E. - Schaffer, J. 2006).

Ezek az internetes egészségügyi szolgáltatások feltehetően elősegítik a betegségteher csökkenését a különböző progresszivitási szintü egészségügyi intézmények és szakemberek esetében, ugyanis a páciensek egyre jelentősebb hányada interneten keresztül próbál választ kapni egészségügyi kérdéseire és problémáira (MATUSITZ, J. - BREEN, G.M. 2007, WICKRAMASINGHE, N. - GEISLER, E. - SCHAFFER, J. 2006).

A telemedicina az előzőeken túl minőségi előnnyel is bír. Így például elősegíti a diagnosztikai hibák csökkenését, hiszen másodlagos és harmadlagos szakvélemények is kérhetők egyes szituációkban. A minőségi változást azonban nem csupán ezek a szakmai állásfoglalások teremtik meg, hanem a betegek aktív bevonása az egészségi állapotuk megismerésébe (lásd vitális paramétereket mérő eszközök használata), a betegségek megelőzésébe és a kezelésbe is. Ráadásul a telemedicinának kitüntetett szerepe van az orvosok oktatásában, továbbképzésében és szakmai elszigeteltségük megszüntetésében is (BÁn A. 2015, DARKins, A. et al. 2008, FiCZERE A. 2010a, 2012a, FiCZERE A. - KÖDMÖN J. 2011, LeVert, D. 2010, MAtusitz, J. - Breen, G.M. 2007, Oudshoorn, N. 2008, STRÖMGREN, M. 2003).

Álláspontom szerint - ami kutatásom eredményei alappján alakult ki (lásd 5. fejezet) - a telemedicina jól müködhet a diagnosztikus szakmák területén (pl. teleradiológia, telepatológia), amelyek az orvosi képalkotással és leletezéssel hozhatók kapcsolatba. Ezenfelül jól alkalmazható még például a belgyógyászat és a kardiológia azon területeiben is, ami köthető az egyes egészségügyi paraméterek (vérnyomás, vércukor stb.) távoli monitorozásához (távfelügyelet). Ugyanakkor vélhetően azokon a területeken és azokban az esetekben, ahol az orvos jelenléte és a gyors döntéshozás feltétlen szükséges (pl. sürgősségi ellátás), tehát amikor az ellátás konkrét személyes, fizikai orvosi vizsgálatot és/vagy beavatkozást jelent, nem csupán képi és egyéb egészségügyi adatok küldésében és értékelésében merül ki, ott nem, vagy csak korlátozottan használhatók a telemedicina adta lehetőségek, legalábbis a jelenlegi technikai feltételek mellett (BÁN A. 2015).

Összességében tehát a telemedicina a szakirodalom szerint meghatározó előnyökkel rendelkezik, amelyek kamatoztathatók minden egészségügyi szereplő számára, és csökkenthetik a területi egyenlőtlenségeket a magasabb szintü szolgáltatások igénybevételénél. 


\subsection{A telemedicina hátrányai és összefüggései az egészségügyi egyenlőtlenséggel}

Az eddig áttekintett előnyök az egészségügyi egyenlőtlenségek csökkenésének irányába hatnak, azonban a helyzet annál lényegesen összetettebb, mint ami elsőként leszürhető belőle, ezért szükséges figyelembe venni a telemedicina esetleges hátrányait, negatív hatásait is.

Egyrészt - STRÖMGREN, M. (2003) szerint - a témával kapcsolatos szakirodalomban általában érzékelhető egyfajta elfogultság a telemedicina iránt, ami abban mutatkozik meg, hogy a kutatók a távellátás pozitív hatásaira fókuszálnak, míg a negatív tényezők kisebb szerepet kapnak, vagy háttérbe szorulnak (STRÖMGREN, M. 2003).

Problémát jelent, hogy a telemedicina hatékonyságának bizonyítékai sokszor hiányosak, a tudományos alap meginog és a módszertan sem minden esetben megfelelö (MAY, C. et al. 2003, WootTon, R. 2012, ZANABoni, P. - Wootton, R. 2012).

Az előzőeken túl ráadásul a telemedicina hatásainak értékelését sokszor csak egy-egy nézőpontból vizsgálják, azonban ezeket legalább három irányból célszerü elemezni. Egyrészt pénzügyi-finanszírozási (költség-hatékonyság) aspektusból, másrészt az elért egészségnyereség szempontjából, harmadrészt pedig a betegek elégedettségének nézőpontjából. Ez utóbbi különösen problematikus, hiszen a páciensek sokszor nem tudnak különbséget tenni a klasszikus és a távellátás között (TAYLOR, P. 2005), ezért a betegek értékelését önmagában nem lehet alapul venni egy hatékonysági vizsgálatnál. A fenti tényezőket célszerü tehát komplexen kezelni, hiszen az egészségügyben a hatékonyság is több elemü (OrOSz É. 2001).

A telemedicina hatásainak elemzésénél azt is érdemes megvizsgálni, hogy egy adott földrajzi környezetben milyen egészségügyi szereplök között valósul meg a távellátás, amit azért is érdemes kiemelni, mert a távgyógyászat új térbeli függőségi viszonyokat hoz létre (BÁn A. 2015, CuTCHIN, M.P. 2002).

Az információs és kommunikációs technológiák alkalmazása az egészségügyi ellátásban hálózatokat generál, amelyek létrehoznak ún. „virtuális ellátási régiókat”. Ezek a régiók nem feltétlen esnek egybe a földrajzi régiókkal, ugyanakkor szorosan kapcsolódnak a valós világ materiális elemeihez, különböző egészségügyi szereplökhöz. Ez abban nyilvánul meg, hogy az ellátás központi szerepkörét a harmadlagos egészségügyi intézmények töltik be, mint speciális ellátást nyújtó kulcsszereplők (CUTCHIN, M.P. 2002, GRIGSBY, J. et al. 2002, STRÖMGREN, M. 2003).

A virtuális ellátási régiókat távellátási hálózatok alakítják ki, melyeknek négy típusát lehet megkülönböztetni. Ezek közül csupán az egyiknél, az ún. elosztott hálózatnál nem mutatható ki egyértelmüen alá-fölérendeltségi viszony, míg három alapvetően hierarchikus jellemzővel bír (6. ábra) (CUTCHIN, M.P. 2002, STRÖMGREN, M. 2003).

Azok a hálózatok, amelyek hierarchikus karakterrel rendelkeznek ,,hub and spoke” típusú hálózatoknak is nevezik, amelyek az ún. „központi hely” (central site) és a „távoli hely” (remote site) közötti kapcsolaton alapulnak (CUTCHIN, M.P. 2002, STRÖMGREN, M. 2003). A hub and spoke hálózatok úgy oszlanak meg a térben, hogy a központot $(h u b)$ mindig urbánus térségben elhelyezkedő egészségügyi intézmények alkotják, míg a hálózat elágazásai (spoke) általában vidéki környezetben találhatók (BASHSHUR, R.L. 1997).

A távoli helyek alapvetően alárendeltségi viszonyban vannak a központi hellyel szemben, ahol az egészségügyi erőforrások koncentrálódnak, ezért a periferikus területeken a telemedicinális alkalmazások is korlátozottak. Az egészségügyi intézmény erőforrásokban való gazdagsága (infrastrukturális felszereltség, eszközállomány, magasan kvalifikált munkaerő stb.) pedig alapvetően meghatározza az ellátás minőségét. Így a speciális klinikai szakértelem a harmadlagos ellátási központokhoz köthető (BÁN A. 2015, CUTCHIN, M.P. 2002, GRIGSBY, J. et al. 2002, STRÖMGREN, M. 2003). 
6. ábra: A telemedicinális hálózatok lehetséges típusai

Egyszerü "hub and spoke" hálózat

Többszörös "hub and spoke" hálózat

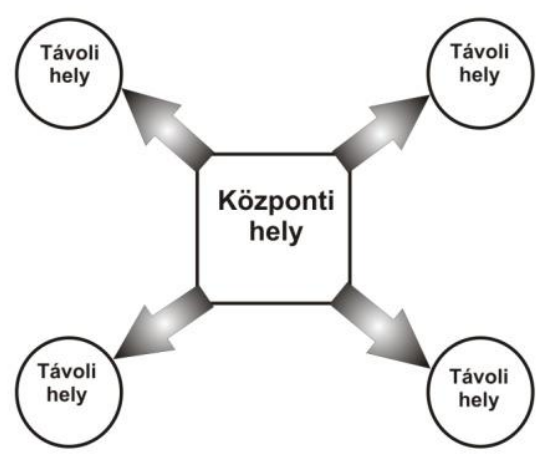

Komplex "hub and spoke" hálózat

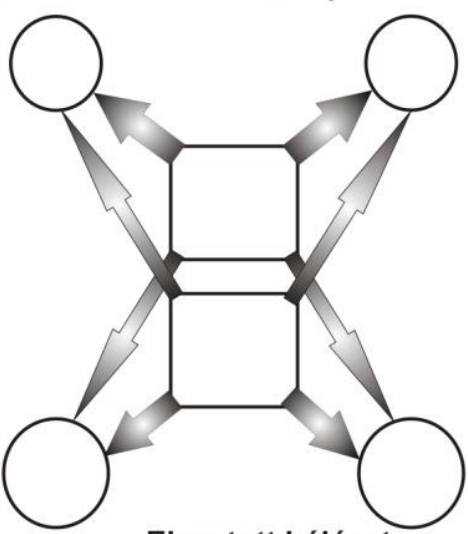

Elosztott hálózat
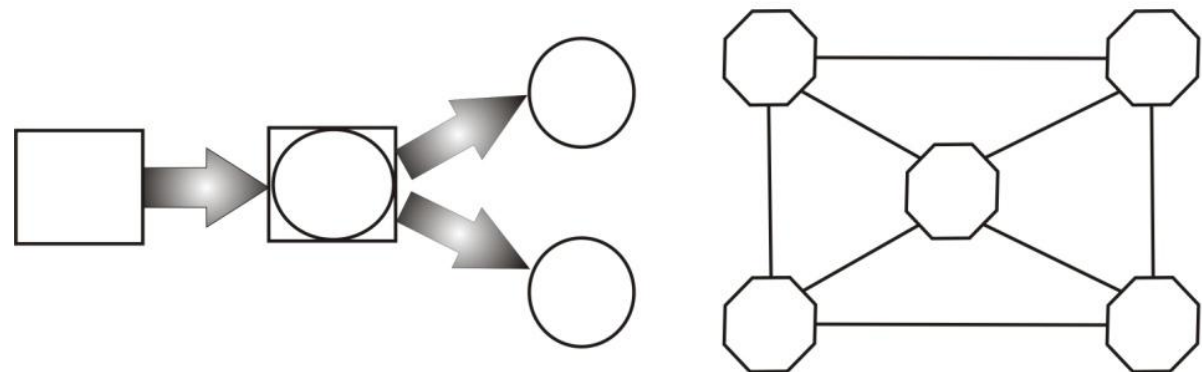

(Forrás: STRöMgen, M. 2003 [GRIGSBY, J. 1997 után] alapján szerk.: Bán A. 2016)

Feltehetően a hub and spoke típusú hálózat elsődlegesen a teleradiológiánál érvényesül (BÁN A. 2015). Ez azért is lényeges, mert a távleletezés a telemedicina legfejlettebb ága (WHO 2010, ZANABONI, P. - WoOTTON, R. 2012). Más szakterületeken - például ahol az egészségügyi paraméterek távoli monitorozását gyakorta alkalmazzák - a telemedicina jelentősebb strukturális változást valószínüleg nem generál, sokkal inkább kiegészítő szerepet kap (BÁN A. 2015).

A telemedicinális szolgáltatások során a távoli helyek bekapcsolódhatnak az ellátásba, ugyanakkor egy földrajzi koncentrálódási folyamat is zajlik. Az infokommunikációs technológiák differenciálják a teret és erősítik a nagyvárosok dominanciáját, aminek köszönhetően az egészségügyi „parancsnoki csomópontok” is a nagyvárosok környezetében jönnek létre. Ebben a tekintetben olyan intézményi csoportosulásról van szó, ami magában foglalja a felsőoktatási (klinikai), diagnosztikai központokat is. A távoli ellátó helyek pedig erősen függő viszonyban vannak ezektől a komplexumoktól (CARTWRIGHT, L. 2000, CASTELls, M. 2005).

AAS $(2007,2013)$ szerint a virtuális szervezeteket és így a távellátási hálózatokat általában nem jellemzi a hierarchia és a parancsnoki központ megléte, ugyanakkor maga is kitüntetett szerepet tulajdonít az egyetemi központoknak (AAS, I.H.M. 2007, 2013). Ezzel ellentétben CUTCHIN, M.P. (2002) szerint a hierarchia egyértelmúen társul a telemedicinához, létrehozva egy újfajta egészségügyi bürokratikus rendszert. Az infokommunikációs technológiák ugyanis hozzájárulhatnak új területek, erőforrások és a hálózat feletti ellenőrzéshez (CUTCHIN, M.P. 2002, NAKAMURA, T. 2007).

Az IKT nem csupán az ellátáshoz való hozzáférést segíti elö, hanem csomópontokat generál az egészségügyi ellátásban (McBAIN, L. - MoRGAN, D. 2005). Ehhez kapcsolódva az empirikus eredmények során szerzett tapasztalatokra utalva (lásd 5. fejezet) - álláspontom szerint, noha a speciális esetekhez szükség van a nagyobb, magasabb ellátási szintü kórházak 
erőforrásaira, azonban a telemedicina a tömegellátás irányába is mutathat. Ezért olyan esetek is magasabb progresszivitású intézmények hatáskörébe kerülhetnek, amelyek egyébként sokszor kisebb kórházakban is elláthatók lennének megfelelő humánerőforrással (BÁN A. 2015).

Egyes kutatók szerint azok az egészségügyi szolgáltatók, amelyek függetlenek más intézménytől, nem kívánnak függő viszonyba kerülni (telemedicinát alkalmazva) más ellátókkal (AAS, I.H.M. 2007, GAGNON, M.P. et al. 2004).

A távellátásban is meghatározó tényező a centralizáció és a decentralizáció kérdése. A szakirodalom szerint a szakmai kompetencia centralizálódik, míg az egészségügyi ellátás decentralizálódik. Ez a teleradiológia esetében például úgy valósul meg, hogy a továbbításra alkalmas digitális képeket több helyen/intézményben hozzák létre, míg ezek értelmezése és kiértékelése egy vagy több központban történik (AAS, I.H.M. 2006a, 2006b, 2007, 2013).

Noha a telemedicina az egészségügyi ellátás decentralizálására törekszik, ennek ellenére a távellátás értelemszerüen nem pótolja a beteg fizikai jelenlétét igénylő ellátást (DARKINS, A. et al. 2008, WoOTTON, R. 1999). Ebböl adódóan miként az infokommunikációs technológiák is csupán kiegészítő szereppel rendelkeznek a társadalmi kapcsolatok építésénél és ápolásánál (CASTELls, M. 2005, GRAHAM, S. 1998), ezért feltehetően a telemedicina is hasonló szerepet kap a beteg személyes jelenlétén alapuló ellátás mellett (BÁN A. 2015).

A telemedicina pozitív hatásait előtérbe helyező nézőponttal szemben tehát van egy ellentétes megközelítés is, miszerint a távgyógyászat az egészségügyi egyenlőtlenség irányába hat, hiszen egyfajta indokként szolgálhat a lokális egészségügyi erőforrásokba való beruházás ellen (CARTWRight, L. 2000, NiCOLINI, D. 2006, 2007).

Ez az álláspont a világot az ellátás terén két jól elkülönített csoportra osztja. Az egyik csoport tagjai azok lesznek, akik számára továbbra is elérhető a klasszikus egészségügyi ellátás, ami a face to face kontaktuson alapul. A másik csoport tagjai számára viszont csupán az infokommunikációs technológiák által támogatott távellátás marad, és a kezelőorvossal való közvetlen fizikai kontaktus elmarad (CARTwRIGHT, L. 2000, NiCOLINI, D. 2006, 2007).

Az előzőekből az következik, hogy a telemedicina növeli a szakmai és a gazdasági hatalom szerepét az egészégügyi ellátásában. A távellátás a hatalmi kapcsolatok kialakulásában tölt be kiemelkedő funkciót, mivel az infokommunikációs technológiák által támogatott interakciók sohasem egyenlö felek között zajlanak. A telemedicinális kapcsolatok kialakulásában az egyik helyen minden esetben kisebb, míg a másik helyen nagyobb mértékü szakmai tapasztalattal, kompetenciával rendelkeznek (CARTWRIGHT, L. 2000, NICOLINI, D. 2006, 2007).

$\mathrm{Az}$ infokommunikációs technológiák által közvetített interakciók esetében ráadásul felmerül az adatvédelem és biztonság kérdése is. Az ún. „kiberterrorizmus” jelensége, ami az illegális adathozzáférésekre és módosításokra utal, a telemedicinális kontaktusoknál (orvosbeteg, orvos-orvos) is jelentkezhet (BreEN, G.M. - MAtusitz, J. - SousA, A. 2008).

Ezenkívül a távellátás nem redukálja a távolságot, hanem létrehozza (lásd interperszonális távolság), hiszen a fizikai érintkezés nem lehetséges az érintett felek esetében, így a direkt kapcsolat megszünik a beteg és az orvos között. Ezáltal a pácienssel való kapcsolattartás egyre inkább az asszisztensek, nővérek feladatkörébe tartozik, míg az orvosok munkája az ún. „spot diagnózisra” redukálódik. Az előkészületeket általában a kisegítő személyzet végzi, akik teljes mértékben részévé válnak a távellátásnak. (Így a telemedicina hatásaként módosulnak, átalakulnak az egészségügyet érintő szervezeti viszonyok.) (CARTWRIGHT, L. 2000, McBain, L. - Morgan, D. 2005, Mort, M. - May, C. R. - Williams, T. 2003, NiCOLINI, D. 2006, 2007).

Noha a telemedicina jobb minőségü ellátást biztosíthat a vidéki területeken, és a háziorvosok közvetítő szerepet töltenek be a betegek, illetve a távoli szakértők között, ez azt 
eredményezi, hogy idővel, jobb esetben a szakorvosok és a páciensek között létrejöhet egy sajátos bizalmi viszony, aminek köszönhetően a háziorvosok kiszorulhatnak e kapcsolatból. Ebből adódóan az alapellátást végző orvos feladatköre redukálódhat a fenti orvos-beteg konzultációk megszervezésére, és így eredeti „kapuő”” szerepét kevésbé lesz képes betölteni. Ezt alapvetően három tényező is erősítheti. Egyrészt speciális esetekről lehet szó, ahol mindenképpen szükség lehet szakorvosra, másrészt a betegek feltehetően igényelik a gyors és szakértő válaszokat a kérdéseikre, harmadrészt pedig a távoli központban dolgozóknak plusz időbe kerül még a háziorvost bevonni az ellátásba (NICOLINI, D. 2006, 2007).

A telemedicina egészségügyi hatásainál további lényeges kérdés, hogy a távellátás miként képes beépülni a klinikai gyakorlatba. Ezt nagyban nehezíti, hogy a telemedicinával kapcsolatos fejlesztésekben sokszor nem kellőképpen veszik figyelembe a klinikai, fogyasztói igényeket és inkább a technológiai „,boom” a távgyógyászat hajtóereje (BASHSHUR, R.L. 1997, Craig, J. - PAtterson, V. 2005, Lehoux, P. et al. 2002, NykÄnen, P. 2006). Ráadásul egy kutatás szerint a telemedicina orvosokat igénylö területe is „eltünőben” van, így egyre nagyobb szerepet kapnak a különböző egészségügyi paramétereket meghatározó készülékek és alkalmazások (FINCH, T. et al. 2006).

Az egészségügyi információk iránti kereslet mindinkább növekszik, ugyanis egyre jobban értékké válik az egészség, valamint annak megőrzése (PÁL V. - UzzoLI A. 2008, 2013). Ehhez kapcsolódóan a távellátáshoz szorosan köthető az interneten elérhető e-egészségügyi szolgáltatások is, melyeknek egyik sajátos formája, amikor a betegek távolról tehetik fel a kérdéseiket az orvosoknak és várhatnak viszonylag rövid időn belül választ, mindezt anélkül, hogy helyváltoztatást végeznének, vagy átadnák a leleteiket az egészségügyi szakembereknek (MATUSitz, J. - BREEN, G.M. 2007).

A problémát az jelenti, hogy az adott információk minősége és érvényessége sokszor nem megfelelő és súlyos egészségügyi károsodást okozhat. Ebből adódóan az orvosok egy része kifejezetten ellenzi az internetes egészségügyi tanácsadást, hiszen a felelősséget csak pontos, biztos diagnózis és személyre szabott kezelés után lehet vállalni. Ráadásul ebben az esetben is felmerül az egyenlőtlenség kérdése, hiszen azok az emberek, akik nem rendelkeznek internet hozzáféréssel, vagy annak használatához szükséges ismerettel, azok kiszorulnak az eegészségügy esetleges jótékony hatásaiból is (BÁN A. 2015, NYKÄNEN, P. 2006). Ezek a korlátozott esélyek és képességek pedig jelentős mértékben hozzájárulnak az egészségegyenlőtlenségek növekedéséhez (PÁL V. 2010, PÁL V. - KISS J. P. - TIPEI, A. 2006, PÁl V. - Uzzoli A. 2010, SÁndor J. 1999, Uzzoli A. 2008, 2012, Uzzoli A. - Szilágyi D. 2013, VitRAi J. et al. 2011).

Az elözőeken túl további egyenlötlenségi problémát indukál az is, hogy a távellátás alapvetően a fejlett országokhoz köthető. Noha az elmúlt években egyre több és több távgyógyászati szolgáltatás indult a fejlődő országokban, mégis a telemedicina ma is a fejlett országokban koncentrálódik. Afrika legtöbb országában, ahol a klasszikus egészségügyi ellátás rendkívüli nehézségekkel küzd és ebből adódóan különösen szükség lenne a távellátás alkalmazására, ahhoz sincs meg a kellő erőforrás, hogy kiépítsék a telemedicinához szükséges infrastruktúrát (CrAig, J. - PATterson, V. 2005, WootTon, R. 1999, WoOtTon, R. et al. 2012).

Összességében tehát a telemedicina egyenlőtlenséget mérséklő hatásai mellett, azok újratermelésére is akad több példa. Ezek a területi differenciák pedig a különbözö, távgyógyászat terjedését is gátló tényezőkre vezethetők vissza. Ugyanis a telemedicina adaptálását és diffúzióját hátráltató barrierek sokszor a távgyógyászat esetében felmerülő - az ellátás elérhetőségével és hozzáférhetőségével kapcsolatos - egyenlőtlenségek kialakító és fenntartó tényezői is lehetnek egyben. 


\subsection{A telemedicina akadályozó tényezői globális léptékben}

A távgyógyászat terjedését és adaptálását számos tényező akadályozza a világ egyes országaiban, melynek egyik legátfogóbb jellemzése az Egészségügyi Világszervezethez köthető. E munkák szerint a telemedicinális szolgáltatásokat a fejlődő és a fejlett országokban sem alkalmazzák még rutinszerüen. A pilot projektek többsége ugyanis a kezdeti finanszírozás után gyorsan megszünik létezni (BROENS, T.H.F. et al. 2007, WHO 2010, ZANABONI, P. - KNARVIK, U. - WoOtTON, R. 2014). Ehhez kapcsolódóan egy fontos kérdés a skálázhatóság, ugyanis e projektek sikeressége a lépték függvénye. Ezek többsége önálló és független rendszert alkot, amely rendkívül költséges és így kevésbé hatékony, ugyanis az interoperabilitás ${ }^{9}$ problémája sokszor nem megoldott (WHO 2012).

Az előzőekhez kapcsolódóan lényeges kérdés a telemedicinális szolgáltatások finanszírozása. Az egészségügyi biztosítók általában ellenállnak minden olyan ellátási formának, ami nem face to face kapcsolaton alapul (BROENS, T.H.F. et al. 2007, MATUSITZ, J. - BREEN, G.M. 2007). Alapvető probléma, hogy hiányosak azok a tanulmányok is, amelyek a telemedicina költséghatékonyságának bizonyítását szolgálnák és ezáltal „meggyőznék” a döntéshozókat a távgyógyászat előnyeiről (WHO 2010, WоотTON, R. 2012).

Egy további fontos kérdés az emberi és kulturális tényező (BROENS, T.H.F. et al. 2007, WHO 2010), ugyanis az egészségügyi szakemberek jelentős része nem preferálja a telemedicinát. Ennek oka többek között, hogy a távorvoslás módszerei eltérnek a megszokott, személyes ellátásétól. Ehhez kapcsolódóan további problémát jelent, hogy az orvosok egy része kevésbé jártas az infokommunikációs technológiák használatában (WHO 2010). A telemedicina hatékony alkalmazásához ugyanis szükséges egyfajta szakértelem, ún. „telekompetencia”. Ebből adódóan az egészségügyi szakemberek meggyőzése arról, hogy sajátítsák el a távgyógyászathoz szükséges ismereteket, rendkívül nagy kihívás (MATUSITZ, J. - BREEN, G.M. 2007).

A WHO szerint a legnagyobb akadályt jelenleg a jogi és politikai tényezők jelentik. Egyrészt idetartoznak az adatvédelem, etika és titoktartás kérdései, másrészt az engedélyezés, valamint a megfelelő elöírások és jogi felelősség meghatározása. Ez utóbbi esetében különösen a technikai problémáknak (hardver, szoftver) és a nyomukban fellépő műhibáknak van jelentősége (Broens, T.H.F. et al. 2007, MAtusitZ, J. - BreEN, G.M. 2007, STANBerRy, B. 2000, WHO 2010).

Mivel a telemedicinális ellátásba bekapcsolódnak profitra törekvő szolgáltatók, további lényeges kérdés, hogyan lehet megvalósítani az egészségügyi szolgáltatásokhoz való igazságos hozzáférést, hogy ne következzen be az ellátás marginalizálódása (WHO 2010).

A telemedicina akadályainak feltérképezése céljából az Egészségügyi Világszervezet 2009-ben készített egy átfogó felmérést, ami érintette a különböző e-health szolgáltatásokat is. A kutatás 114 országra terjedt ki, ami a WHO tagállamok közel 60 százalékát, míg a világ népességének több mint 80 százalékát érintette (WHO 2011).

Ebben a felmérésben 10 potenciális tényezőt lehetett választani, ami akadályozhatta a telemedicinális szolgáltatások bevezetését. Mindez annak érdekében történt, hogy standardizálhatóvá váljanak a válaszok. A 10 tényező közül minden egyes ország négy olyan akadályt választhatott, amely leginkább meghatározó volt esetében (WHO 2010, 2011).

A leggyakoribb tényező a magas költség volt, amit a 114 ország több mint 60 százaléka jelölt meg potenciális akadályként (7. ábra). További öt szegmens megoszlása minden

9 „A különböző informatikai rendszerek együttmüködésre való képessége” [5]. 
esetben 40 \% körül alakult, amelyek közé tartozott a jogi szabályozás, a szervezeti kultúra, a fejletlen infrastruktúra, a politikai berendezkedés, valamint a prioritások (BÁN A. 2013c).

Érdekes módon a kereslet hiánya a szakemberek tekintetében a legkevésbé problémás tényező, vagyis igény feltehetően több ország esetében is lenne rá. Ehhez hasonlóan a szükséges technikai szakértelem sem jelent különösebb problémát. Ezzel ellentétben az egyes alkalmazások ismerete, valamint az elfogadott sztenderdek hiánya továbbra is meghatározó (BÁN A. 2013c).

\section{7. ábra: A telemedicinális szolgáltatások akadályai egy 2009-es WHO felmérés szerint}

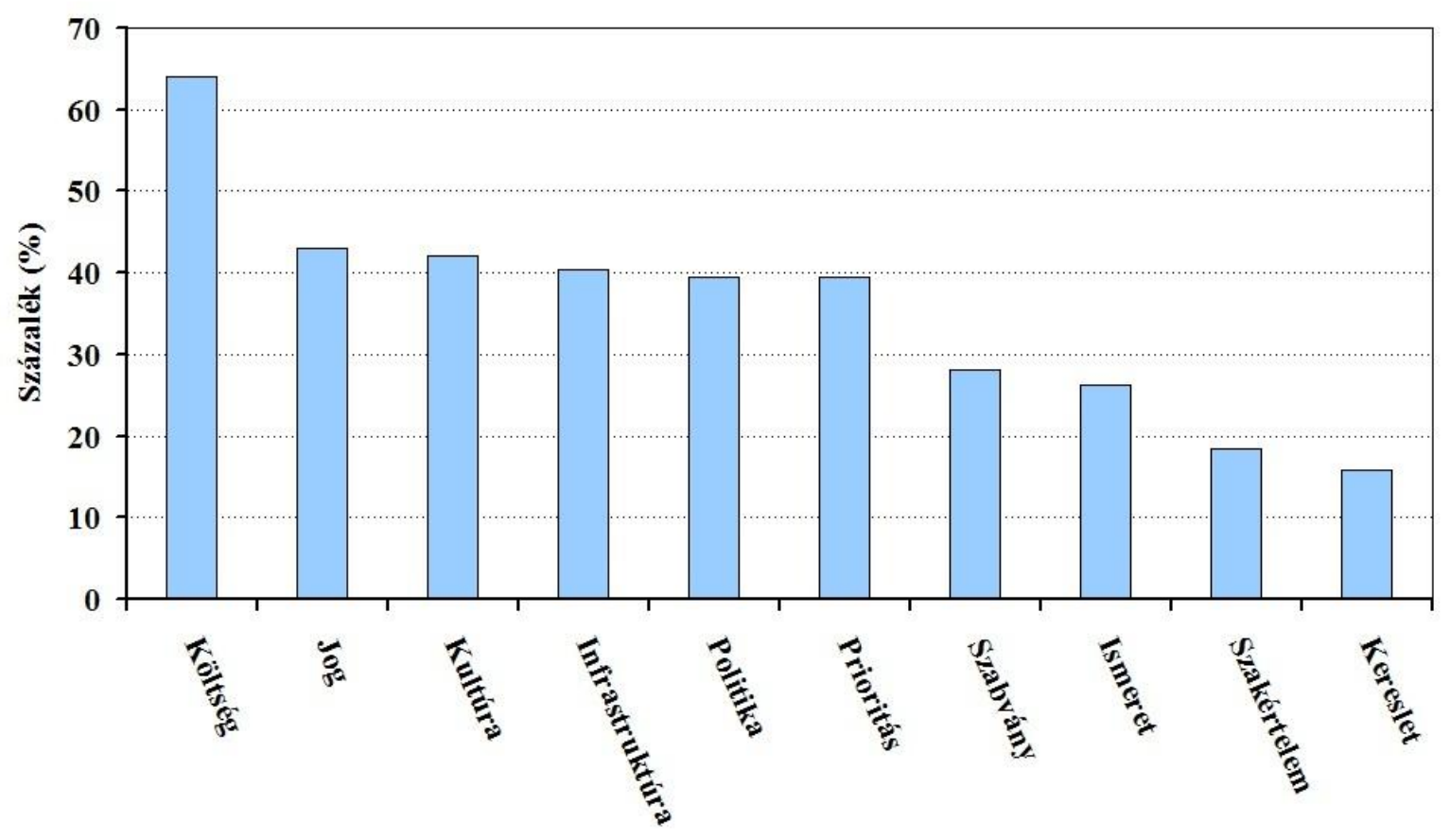

(Forrás: WHO 2011 alapján szerk.: Bán A. 2016)

A fejlődő és a fejlett országok az egyes akadályok tekintetében viszonylag jól elkülöníthetők. A fejlődő országokban nagyobb szerepet kapnak a magas költségek, a fejletlen infrastruktúra és a technikai szakértelem hiánya. Ezzel ellentétben a fejlett országokban a jogi kérdések, az egészségügyi rendszer prioritásai és a kereslet esetleges hiánya jelentenek gondot (WHO 2011).

Az Egészségügyi Világszervezet felmérése szerint az észlelt magas költségek jelentik a legnagyobb problémát a világon és különösen a fejlődő országokat érintik. Az adatok térképi megjelenítése az előzőeket teljes mértékben igazolja, hiszen az egyes kontinenseken az országok jelentős hányadánál megmutatkozik ez a probléma ( 8 . ábra).

Afrikában, Ázsiában és Amerikában a kutatásba bevont országok több mint kétharmadában, míg az európai országok felében jelentkezik ez az akadályozó tényező. Ugyanakkor a fejlett országok is érintettek, úgymint Kanada, USA, Franciaország, Izland, Norvégia stb. Ezzel ellentétben, az olyan országokban, mint például Albánia, Bulgária, vagy éppen Mali, a költséget nem tartják problémának. Amennyiben ezzel a gátló tényezővel ellentétben viszont a fejletlen infrastruktúra a vizsgálat tárgya, úgy kisebb gyakorisággal fordulnak elő a fejlett országok (BÁN A. 2013c). 


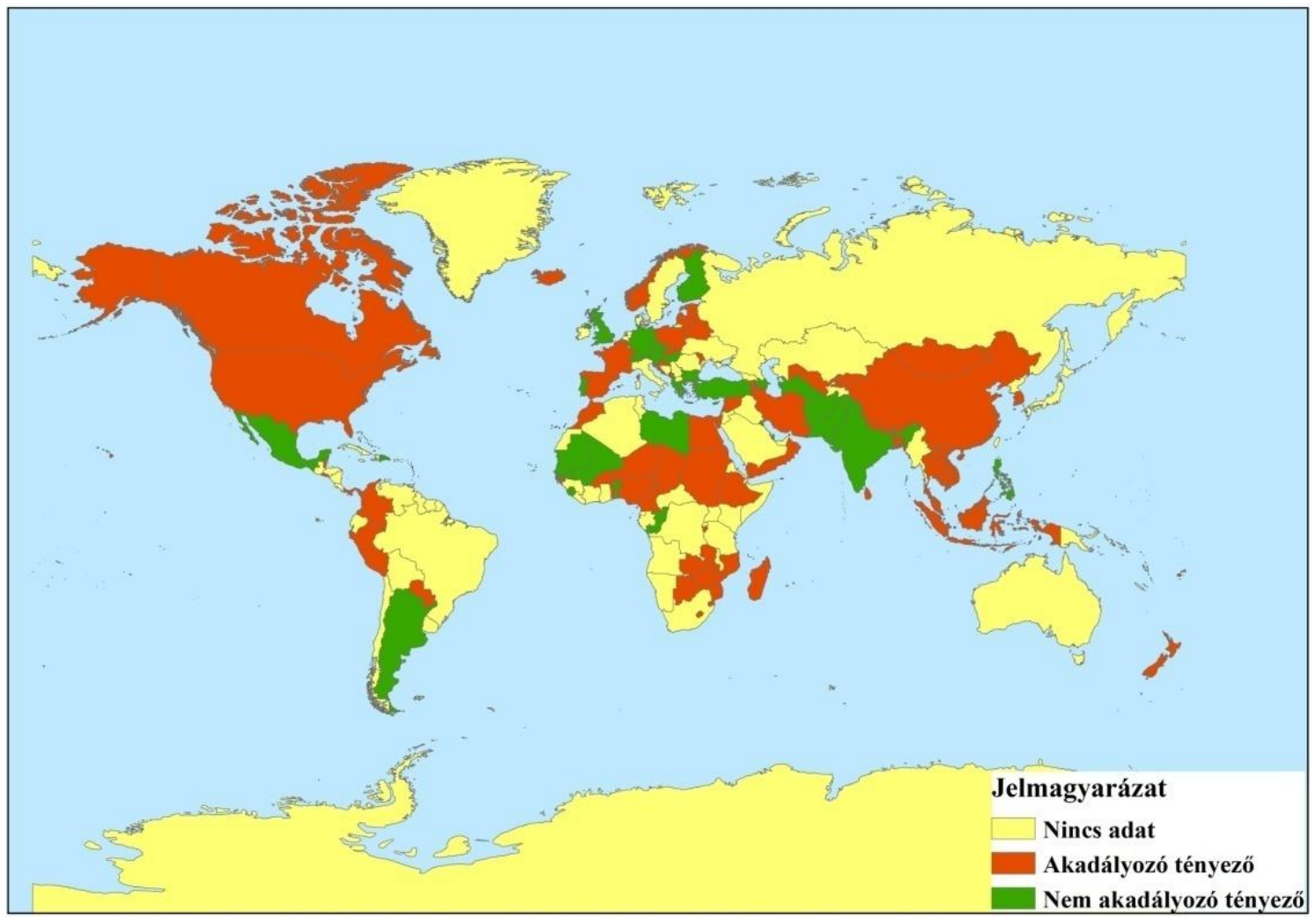

(Forrás: WHO 2011 alapján szerk.: Bán A. 2016)

Globálisan a második leggyakoribb akadályozó tényezők a jogi kérdések, amelyek különösen a fejlett országokat érintik. A felmérésben érintett európai országok több mint 60 százalékában a jogi szabályozás hiátusa barrierként jelentkezik (9. ábra).

\section{9. ábra: A jogi szabályozás hiánya, mint telemedicinális akadály területi megoszlása}

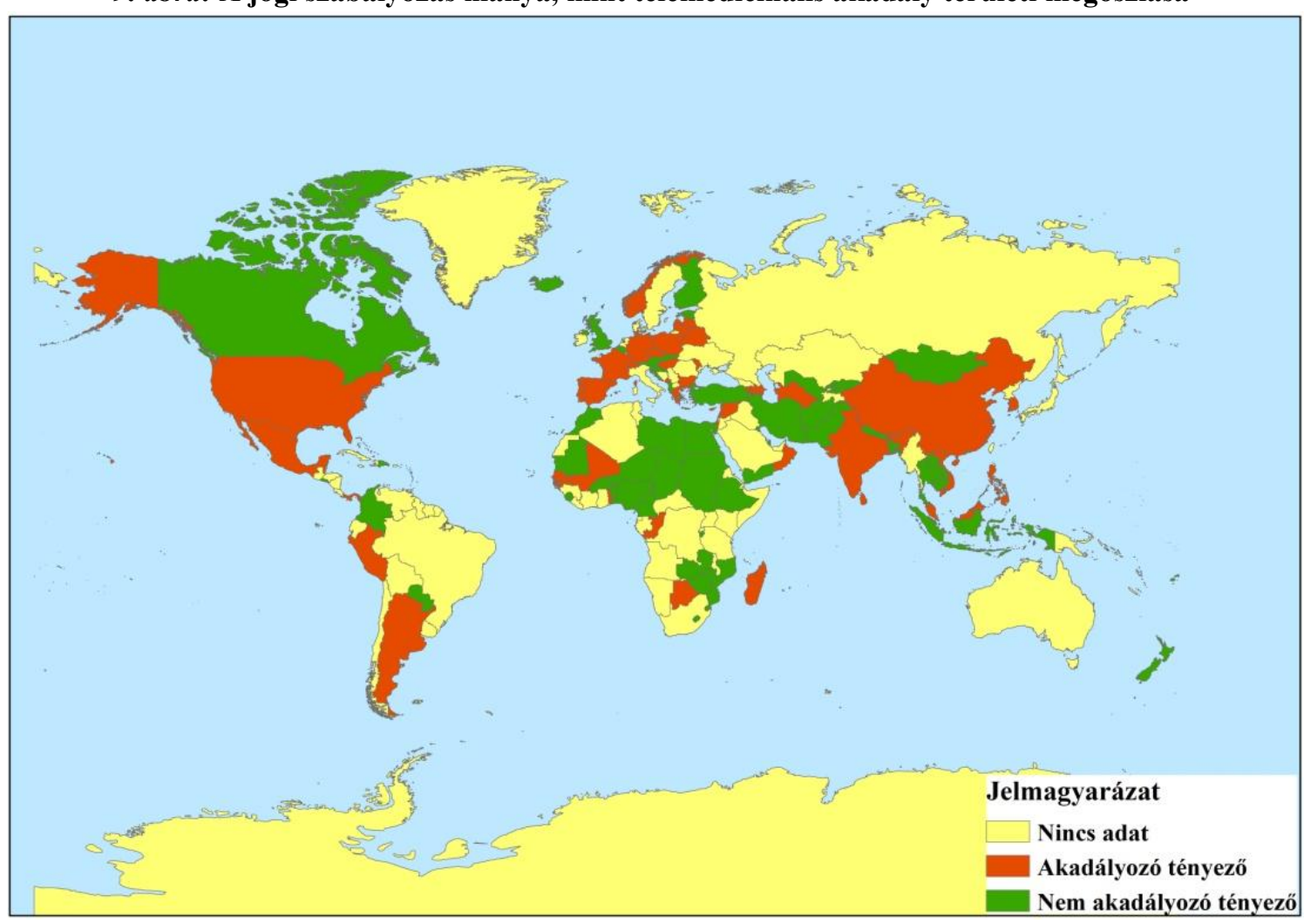

(Forrás: WHO 2011 alapján szerk.: Bán A. 2016) 
Természetesen itt is találhatók ellenpéldák, úgymint Ausztria, Svájc, vagy éppen az Egyesült Királyság. Európával ellentétben, Afrikában az érintett országoknak kevesebb mint a 30 százalékában jelentenek csupán problémát a jogi kérdések. Összességében elmondható az egyes akadályok esetében, hogy a választásukban az objektív, tényleges helyzettől eltekintve nagy szerepet lehet tulajdonítani a szubjektív megítélésnek is (BÁN A. 2013c).

Tekintettel a nemzetközi szakirodalomra, amelyben egyes szerzők különösen nagy hangsúlyt fektetnek a fejlődő országokban megfigyelhető akadályokra (WOOTTON, R. 2001, 2008, 2009), érdemes részletesebben is elemezni a telmedicina alkalmazását gátló tényezőket.

Az Egészségügyi Világszervezet által taglalt és rendszerezett barrierek, amelyek a fejlődő országokban is jelentkeznek, a hatásaik hatványozottan érvényesülnek (WHO 2010). A telemedicinális projektek hosszú távú múködése a fejlett országokban sem mutat túlságosan kedvező képet (ZANABONI, P. - KNARVIK, U. - WoOTTON, R. 2014), a fejlődőekben pedig még kevésbé tekinthetők a klinikai rutin részének (WoOTTON, R. 2001, 2008, WoOTTON, R. BONNARDOT, L. 2010).

A telemedicina megfelelő alkalmazásának egyik legnagyobb gátja - sok egyéb, korábban már felvázolt tényezők mellett - az utóbbi országokban az infokommunikációs technológiákhoz köthető. Természetesen az IKT sem elégséges feltétel egy jól működő és életképes telemedicina rendszerhez, valamint annak fenntartásához, de annak egyik sarokköve. Ebben a tekintetben alapvető probléma a szélessávú hálózatok meglétének hiánya és/vagy elérhetősége, a szükséges infrastrukturális berendezések, a megfelelő hardverek és szoftverek hiánya, illetve magas költsége (WoOTTON, R. 2009). Az információs és kommunikációs technológiák használatának fajlagos költsége meglehetősen magas például Afrika egyes országaiban, ahol monopóliumok uralják a távközlési piacot (MARS, M. 2009, NAGY G. 2010).

Ráadásul az országon belüli differenciák is megmutatkoznak, ugyanis a vidéki térségekben, ahol vélhetően nagyobb szükség lenne a telemedicina jótékony hatásainak kiaknázásra, a költségvetési nehézségek nem teszik azt lehetővé (CHEN, J. - XIA, Z. 2009). Ugyanakkor egyes szerzők szerint a sikeres telemedicinának nem lenne alapvető feltétele a drága technológia megléte (WoOTTON, R. 2001, 2008).

A fejlődő országokban a telemedicinát mindenekelőtt oktatási célokra használják és csupán elenyésző részét alkalmazzák a klinikai gyakorlatban, legtöbbször másodlagos szakvéleményeknél veszik igénybe. A videokonferenciás távkonzultációs lehetőségek (és sok esetben a nagyobb fájlméretű képek küldése is) a távközlés magas fajlagos költségei miatt háttérbe szorulnak, ezért sokkal inkább az e-mailes üzenetküldések a jellemzők (MARS, M. 2009, Wootton, R. 2001, 2008, 2009, WootTon, R. - BonnARdot, L. 2010).

A jövőbeni fejlesztéseket pedig - ami döntően a politikai akarat függvénye - jelentősen hátráltatja a szükséges értékelések hiánya és a telemedicina költséghatékonyságának igazolása a fejlődő országokban (CHEN, J. - XIA, Z. 2009, MARS, M. 2009, WoOTTON, R. 2001, 2008, 2009, WoOtTOn, R. - BonNARdot, L. 2010).

Paradoxon a fejlődő országokban, hogy viszonylag alacsony a telemedicina használata, annak ellenére, hogy a távgyógyászat hozzájárulhatna az ellátás javításához. Ráadásul a telemedicinális esetek száma is stagnál. Mindez annak ellenére, hogy a becslések szerint az egészségügyi kereslet mindössze 0,1 százalékát fedezi, tehát igény valószínüsíthetően lenne rá (Wootton, R. 2008, Wootton, R. - Bonnardot, L. 2010).

$\mathrm{Az}$ alacsony igénybevételt részben a fenti gondolatok, részben pedig egyéb tényezők is magyarázhatják. Egyik oka lehet ezeknek a szolgáltatásoknak a (sok esetben) térítés 
mentessége, amit feltételezhetően kevésbé becsülnek meg, és így kisebb gyakorisággal alkalmazzák. Másrészt problémát jelent a másodlagos szakvélemény megszerzése, amit az is nehezít, hogy a távoli segítség kérése egyet jelent a kompetencia hiányának elismerésével, egyfajta kudarccal és a fejlett világban dolgozó szakembertől való függéssel. Ez egyébként elsősorban a fejlődő országokra jellemző specifikum, ugyanis a nyugati társadalom orvos szakértői esetében nagyobb a hajlandóság külső specialista bevonására (WOOTTON, R. 2008).

Természetesen a helyi tapasztalat és szakértelem a helyspecifikus betegségeknél sok esetben meghatározóbb lehet, mint a távoli specialista kompetenciája, ami szintén hozzájárul az igénybevétel mellőzéséhez. Ezenfelül a külső szakértők által nyújtott tanácsok sok esetben a lokális egészségügyi viszonyok és erőforrások figyelembe vételén alapulnak, így kevésbé alkalmazhatók egy attól idegen, szűkös egészségügyi erőforrásokkal rendelkező rendszer esetében (WoOTTON, R. 2001, 2008).

Ráadásul a másodlagos és harmadlagos szakvélemények kérése azért is problematikus, mert a fejlődő országokban dolgozó egészségügyi szakemberek még inkább leterheltek, amit erösít az orvosok és ápolók jelentős hiánya. Ezenkívül a távoli specialisták (és hálózatok) gyakori bevonása az ellátás feletti bizonyos kontrollfunkciók feladásával is társulhat (MARS, M. 2009, WoOtTON, R. 2008).

Természetesen a telemedicina alkalmazásának számos egyéb gátló tényezői is ismertek, mint például a finanszírozás és a megfelelő szakértelem hiánya, a szakemberek attitüdje, minőségbiztosítási, jogi és etikai kérdések (CHEN, J. - XIA, Z. 2009, MARS, M. 2009, WoOTTON, R. 2001, 2009), melyek már korábban bemutatásra kerültek.

A telemedicina akadályozó tényezői azonban nemcsak az egyes országok tekintetében, hanem azon belül, szubnacionális területi szinten is elkülöníthetök, hiszen más jellegü problémák merülhetnek fel például a rurális területeken, mint az urbánus térségekben. Ráadásul a fejlődő országokra jellemző, a telemedicina alkalmazását gátló barrierek sokszor hasonló jellegüek is lehetnek a vidéki térségekben (és a fejlett országok perifériáin) tapasztalhatókhoz.

\subsection{A vidéki területek egészségügyi ellátási problémái és a telemedicina}

A vidéki és városi lakosság között több szempontból is dichotómiát lehet felfedni. Egyrészt a vidéken élők általában alacsonyabb jövedelmüek (és sokszor alacsonyabb iskolai végzettséggel rendelkeznek), mint a városlakók. Másrészt sokszor súlyosabb egészségügyi problémákkal küzdenek, mint a városban élök. Ráadásul a vidéki lakosság ki van téve az egészségügyi egyenlőtlenségeknek is, hiszen a megfelelő egészségügyi ellátáshoz való hozzáférés sokkal nehezebb, mint a városokban (CuTCHIN, M.P. 2002, SMITH, A.C. et al. 2005).

A vidéki egészséggondozásban egyre nagyobb problémát jelent a fenntarthatóság kérdése, a megfelelő egészségügyi személyzet (orvos, ápoló) biztosítása. Erre egyfajta megoldást jelenthet a telemedicina, amely alternatív egészségügyi ellátási formaként jelenik meg (BÁN A. 2013a).

Egy, a vidéki kórházakban végzett felméréseken alapuló amerikai tanulmány szerint a telemedicinát használó intézmények kétharmada két évnél kevesebb ideje alkalmazza ezt a szolgáltatást. Ennek terjedése ugyanis lassúnak bizonyul, míg a beszerzési és müködtetési költségek rendkívül magasak (HASSOL, A. et al. 1997). 
Az elözőeken felül az egyes telemedicinális projektek során további akadályozó tényezők is jelentkeznek, amelyek hátráltatják a távellátás használatát. Egyik ilyen probléma a bizonytalanság kérdése. A telaradiológián kívül ugyanis nem rendelkeznek megfelelő elöírásokkal, sztenderdekkel a telemedicinális kezeléseket, konzultációkat illetően. Egy másik hátráltató tényező a távkonzultációk megfelelő időrendi tervezésén alapul, ami problémát jelent a vidéki szolgáltatónak és a specialistának egyaránt. Ebben szerepet játszik az utazás, az időponti kötöttség, továbbá a konzultációk sokasága. Végül, de nem utolsó sorban pedig az egyes szolgáltatásokat sokszor az ún. „,klinikai bajnokok” határozzák meg. Az általuk nyújtott szolgáltatás nem minden esetben felel meg a vidéki lakosság igényeinek, szükségleteinek (HASsOL, A. et al. 1997).

Az infokommunikációs technológiák által létrehozott virtuális ellátási régiók tekintetében is felmerül a kérdés, hogy a telemedicinális hálózatok diffúziója milyen mértékben lesz sikeres a vidéki környezetben? Képes lesz-e javítani az ellátáshoz való hozzáférést úgy, hogy az igazságos elosztáson alapuljon? Feltehetően ez nem fog megvalósulni maradéktalanul sok vidéki területen (CuTCHIN, M.P. 2002).

A sikeres telemedicina hálózatot több tényező is akadályozza. Egyrészt rendkívül fontos, hogy a helyi szolgáltatók elérjék a „kritikus tömeget” és időt a megfelelő és gazdaságos müködéshez. Másrészt a csomópontok közötti távolság és így az egyes szolgáltatók közötti társadalmi kapcsolat is alapvetően meghatározza a hálózatok sikerességét. További befolyásoló tényező lehet a telemedicinális szolgáltatást nyújtó orvosok státuszának változása, valamint a helyi társadalom attitüdje (CUTCHIN, M.P. 2002).

Összességében elmondható, hogy a rurális térségek a korábban jelzett barriereken kívül speciális problémákkal is szembesülnek, amelyek a jövőben megoldásra várnak az ellátásban jelentkező területi differenciák mérséklése érdekében. Ez azért is releváns, mert a vidéken élők az egészségügyi egyenlőtlenségek tekintetében különösen érintettek és ezek mérséklésében a telemedicina szerepet játszhat. Ugyanakkor könnyen megeshet az is, hogy ha a távgyógyászat akadályai továbbra is fennmaradnak, akkor az érintettek még inkább marginalizálódnak.

\subsection{Az idős emberek telemedicinával kapcsolatos attitüdjei}

A telemedicina használatát gátló tényezők az előzőekkel ellentétben nem csupán területi léptékben jelentkezhetnek, hanem az egyén esetében is. Ebben a tekintetben pedig különösen releváns az idős emberek attitüdjeinek, esetleges félelmeinek vizsgálata, hiszen esetükben feltehetően jelentős egészség-nyereséget is el lehet érni a telemedicinális szolgáltatás igénybevételével. Egy amerikai tanulmány különbözö szakmai folyóiratokat és interneten fellelhető anyagokat felhasználva ismerteti azokat a lényegesebb pontokat, amelyek jellemzik az idősek telemedicinával kapcsolatos attitüdjeit $\left(\mathrm{NMRC}^{10} 2007\right)$.

A távoli betegmonitoring egyfajta megoldásként szolgál az öregedés társadalmi-gazdasági problémáinak egy részére, azonban érdemes figyelembe venni a telemedicina felhasználóinak aggodalmait, mint releváns akadályozó tényezőket (NMRC 2007).

Az idősek nehezen fogadják el a távgyógyászatot, mert a használata kompetencia hiányában sokszor gondot okoz. Általában kevésbé fogékonyak, illetve érdekeltek az infokommunikációs technológiákon alapuló egészségügyi szolgáltatások iránt. Ennek

\footnotetext{
${ }^{10}$ New Millennium Research Council
} 
köszönhetően egyre inkább kialakul az ún. digitális szakadék köztük és ezeket a technológiákat rendeltetésszerüen használók között, ami a társadalmi és az egészségügyi egyenlőtlenséget tovább is erősítheti (NMRC 2007, SANDERS, C. et al. 2012).

Ráadásul az idősebb generáció általában előnyben részesíti a klasszikus orvosi ellátást, ugyanis a face to face kontaktus hiánya egyesek álláspontja szerint negatív hatással lehet a társadalmi kapcsolatokra (pl. család, orvos stb.) A megbélyegzéstől, az elszigeteltségtől való félelem miatt fenntartással vannak a telemedicina iránt (NMRC 2007). Ráadásul egyesek nem akarnak tudomást venni az öregséggel járó kiszolgáltatottságról. Ebből adódóan lehetőség szerint próbálnak elhatárolódni annak minden vonzatától, így a telemedicinát az identitás veszélyeként, illetve függőségként azonosítják (SANDERS, C. et al. 2012).

A távmonitorozó készülékek használatától azért is tartanak, mert ez egyrészt hozzájárulhat egyfajta szerepcseréhez gyermekeikkel szemben, másrészt félnek attól, hogy a telemedicina használatával gyermekeik „lemondanak” róluk. Még akkor is, ha éppen ezekkel ellentétesen, a nagyobb biztonságot és gondoskodást szolgálná a távgyógyászati szolgáltatás (NMRC 2007).

A távoli betegmonitoring használata ellen hatnak az olyan káros sztereotípiák is, miszerint az idősek nem képesek ezeket a készüléket rendeltetésszerüen használni. Ezek szerint ugyanis fizikai és/vagy szellemi képességük nem teszi lehetővé az egyes eszközök megfelelő alkalmazását (NMRC 2007).

Ezekhez az akadályokhoz járul hozzá a személyes adatok megosztásától, illetve annak következményeitől való félelem, ami hátráltatja a távkonzultációkat is. Ezenkívül az idősek sokszor bizalmatlanok a telemedicinával kapcsolatban, ugyanis aggódnak az esetlegesen felmerülő technikai hibáktól (NMRC 2007).

A fent felsorolt tényezők miatt az idős generáció általában közömbös és érdektelen a telemedicinával kapcsolatban. Ugyanakkor ezek az akadályok elsősorban pszichológiai eredetűek, ezért képzéssel és megfelelő tájékoztatással jelentős részük feltehetően megszüntethető lenne (NMRC 2007, SANDERS, C. et al. 2012).

\subsection{Néhány szakirodalmi javaslat a telemedicinális akadályok lebontására}

Az előző alfejezetekben tárgyalt, a távgyógyászat terjedését és adaptálását gátló tényezők, mint például a pénzügyi, technikai, szabályozási, szervezeti, kulturális stb. bizonyos fajtáik lebonthatók.

Egyik alapvető probléma, hogy a telemedicinális szolgáltatások a mai napig nem megfelelően szabályozottak. Ezért egy olyan modell kiépítésére lenne szükség, amely lehetővé tenné az akkreditációt, a minőségbiztosítást, a megfelelő technikai és a konkrét eljárási sztenderdek kidolgozását, az országon belüli és a határokon átnyúló szolgáltatás engedélyezését. Egy szervezeti eljárás keretében kellene integrálni ezeket a szolgáltatásokat az egészségügyi rendszerekben. Ezek megvalósításának sikere viszont a politikai akarat függvénye (GrigsBy, J. et al. 2002, RogOVE, H.J. et al. 2012, TANRIVERDI, H. - IACONO, C.S. 1999).

Ehhez kapcsolódóan lényeges lehet egy olyan telemedicinális adatbázis létrehozása, amely nemcsak keretbe foglalná az egyes projekteket, hanem értékelné is azokat a gazdasági környezet és az egészségügyi rendszerek szerint (GRIGSBY, J. et al. 2002).

További releváns elem lenne, hogy az Egészségügyi Világszervezet a középpontba állítsa a telemedicinát és járuljon hozzá az egyes országok telemedicinális rendszerének tervezési és 
fejlesztési sikeréhez. Ez akkor lehetséges, ha a WHO a témával kapcsolatos teljes szakirodalmat átfogja és elérhetővé teszi (GRIGSBY, J. et al. 2002).

Ezt kiegészítve az egyes szervezeteknek (pl. WHO, WTO stb.) olyan egyezményeket kellene létrehozniuk, amelyben lefektetnék a nemzetközi távorvoslási szolgáltatásoknak és szabványoknak a jogi alapjait (GRIGSBY, J. et al. 2002).

Mivel a telemedicina egészségügyi innovációként értelmezhető, szükséges a hatékonyságát számadatokkal is bizonyítani (ZANABONI, P. - WoOTTON, R. 2012). Ehhez nélkülözhetetlenek az üzleti modellek kidolgozása, amelyek a megtérülést és a jövedelmezőség kérdését is taglalják. Ráadásul olyan fizetési mechanizmusok kialakítására van szükség, amelyekben a klasszikus ellátással szemben a távorvoslási tételek is elszámolhatók (RoGOVE, H.J. et al. 2012, TAnriverdi, H. - Iacono, C.S. 1999, Whitten, P. - Holtz, B. - Nguyen, L. 2010).

Az egészségügyi ellátásban a face to face kontaktus a megszokott forma és az orvosok többsége ragaszkodik is ehhez. A telemedicina elfogadtatásához meg kell győzni az egészségügyi szakembereket. Ezért lehet nagy szerepe az oktatási-képzési programoknak, amelyek körvonalazzák a telemedicina hatékonyságát és biztonságosságát (RoGOVE, H.J. et al. 2012, TANRIVERDI, H. - IACONO, C.S. 1999).

Összességében tehát a távgyógyászat alkalmazása előtt álló akadályok megszüntetése jelentős mértékben függ a politikai/egészségpolitikai döntéshozók, az egészségügyi vezetők, illetve általában a szakmai szervezetek és azok tagjainak állásfoglalásától, hozzáállásától. Az egyének telemedicinával kapcsolatos attitüdjét viszont számos tényező determinálhatja, amelyek magyarázatára több elmélet is kísérletet tesz. Ebből adódóan célszerü ezeknek a teóriáknak a rövid bemutatása. 


\section{A telemedicina adaptálását és alkalmazásának terjedését magyarázó fontosabb elméletek}

Egy innováció bevezetését - mint amilyen a telemedicina is - számos tényező determinálhatja. Az adaptálás általában több faktor figyelembe vétele mellett történik, úgymint a megvalósításhoz szükséges források és lehetőségek - beleértve a finanszírozás, a nélkülözhetetlen készségek és képességek kérdését, valamint a rendelkezésre álló időt -, a potenciális előnyök és hátrányok, vagyis, hogy mennyivel lesz kedvezőbb (hatékonyabb) a felhasználó mindennapjai, a gyakorlatban mennyire hasznosítható (SPIL, T.A.M. 2006).

Ezeket a paramétereket természetesen felülírhatják az egyén megnyilvánulásai, érzései, sztereotípiái, attitüdjei az adott termékkel, szolgáltatással, vagy innovációval kapcsolatban, csak úgy, mint a társadalom prominens tagjainak a véleménye és adaptációs hajlandósága (SPIL, T.A.M. 2006).

Összességében egy komplex, bonyolult és multifaktoriális rendszer magyarázza az adott innováció, jelen esetben a telemedicina alkalmazását. Ezt a sokdimenziós struktúrát és folyamatot próbálja néhány elmélet elemekre bontani, egyszóval egyszerüsíteni és modellezni. A továbbiakban összesen öt teória rövid bemutatására törekszem, amelyek különbözö léptékben magyarázzák a telemedicina adaptálását meghatározó tényezőket.

Ezek közé tartozik GIDDENS strukturációs elmélete, a cselekvőhálózat elmélet, ROGERS innovációs teóriája, továbbá a technológia elfogadásának modellje és a tervezett cselekvés/magatartás elmélete.

A fenti elméletek kiválasztását több tényező is indokolja. Egyrészt a telemedicina nemzetközi szakirodalmában ezek az elképzelések gyakorta megjelennek (HU, P.J. et al. 1999, LEHOUX, P. et al. 2002, Sun, Y. et al. 2013, ZANABOni, P. - WootTon, R. 2012, ZhANG, X. et al. 2015), ami különösen vonatkozik az utóbbi három, egyén szerepét vizsgáló elméletre, illetve valamelyest a strukturációs teóriára. Másrészt az infokommunikációs technológiák térbelitársadalmi hatásaival, illetve adaptálásával foglalkozó szakirodalomban a cselekvőhálózat elmélet markáns szerepet kap (GRAHAM, S. 1998). Tekintettel pedig arra, hogy a távgyógyászat kialakulása és használata is ezekhez a technológiákhoz kötött, így ez alkalmazható a telemedicina adaptálásának magyarázatánál is. Ráadásul azért is esett a választásom a fenti tudományos elképzelésekre, mert a szakirodalom ezeket az elméleteket az adott társadalmi folyamatot, jelenséget demonstrálva - részletesen, viszonylag könnyen értelmezhető formában taglalja.

\subsection{Az innováció terjedésének elmélete}

Az innováció terjedésének elmélete EVERETT ROGERS nevéhez köthető, ami széleskörü empírián alapul. Ebben a teóriában a diffúzió azt a procedúrát jelöli, amikor a társadalom egyes tagjai között megjelenik az adott innováció, ami egy új ötletet, gyakorlatot jelent. Az előzőeken túl, az innováció terjedésénél egy további meghatározó fogalom az innovatívság, ami azt fejezi ki, hogy a társadalom bizonyos tagjai gyorsabban adaptálnak egyes innovációkat másoknál, tehát ez egyfajta méröszám. Ez alapján több típust lehet megkülönböztetni, úgymint innovátorokat, korai elfogadókat, korai többséget, kései többséget és sereghajtókat (Rogers, E.M. 1983, SPIL, T.A.M. 2006, ZHANG, X. et al. 2015).

Ezekbe a kategóriákba tartozók különbözőképpen oszlanak meg, annak megfelelően, hogy milyen korán adaptálják az adott innovációt. Az első típusba az innovátorok tartoznak, akik az egyének mindössze 2,5 százalékát jelölik. Az érintetteket a bátorság és a vállalkozói szellem 
jellemzi, akik elsősorban kozmopoliták. Lényegében a rendszer kulcsszereplői, mivel meghatározó szerepük van a diffúzió terjedésében, ami abból adódik, hogy ők csatornázzák be, illetve indítják el az innovációkat. Ehhez sajátos tudással és képességgel kell rendelkezniük, ami abban is segíti őket, hogy az esetleges bizonytalanságot és veszteséget elviseljék, hiszen ezeknek az innovációknak a bevezetése jelentős költséggel és kockázattal is jár (Rogers, E.M. 1983, SPIL, T.A.M. 2006, ZHANG, X. et al. 2015).

A következő csoportot a korai elfogadók adják, akik az egyének 13,5 százalékát jelentik. Ebbe a típusba tartozók már lokális, helyi kötődésűek az innovátorokkal ellentétben. Fontosságuk abban rejlik, hogy információval látják el az érdeklödőket az innovációról (Rogers, E.M. 1983, SPIL, T.A.M. 2006, ZhANG, X. et al. 2015).

A korai többség részesedése az előzőekhez képest jóval meghatározóbb a maguk 34 százalékával. Az átlagnál valamelyest korábban adaptálják az adott innovációt. Ez az ún. „gondolkodó” típus, aminek tagjai alaposan meggondolják az innováció bevezetését, ugyanakkor törekednek arra, hogy jelentősen ne maradjanak le (ROGERS, E.M. 1983, SPIL, T.A.M. 2006, ZHANG, X. et al. 2015).

A kései többség a korai többséghez hasonlóan szintén 34 százalékos részesedéssel bír. Az érintettek a rendszer átlagos tagjai után adaptálják az adott innovációt, ami arra vezethető vissza, hogy rendkívül bizalmatlanok és ezért elövigyázatosak azokkal szemben (RoGERS, E.M. 1983, SPIL, T.A.M. 2006, ZHANG, X. et al. 2015).

Az utolsó csoportot pedig a sereghajtók adják, akik az egyének 16 százalékát érintik. Sajátos jellemzőjük a lokalitás (mélyebb beágyazottság) és az elszigeteltség. A változást a legkevésbé preferálják és ezáltal az innovációt kevésbé fogadják el, mint a többi csoport. Ez abból adódhat, hogy az innovációhoz szükséges forrásaik meglehetősen behatároltak, ezért azokat csak olyan esetben alkalmazzák, amikor megbizonyosodnak arról, hogy annak bevezetése nem társul kedvezőtlen helyzettel és nem jár semmiféle kudarccal (ROGERS, E.M. 1983, SPIL, T.A.M. 2006, ZHANG, X. et al. 2015).

Az innovációk bevezetését minden esetben egy komplex döntési mechanizmus határozza meg, ami alapján öt szakaszt lehet megkülönböztetni. Az első a tudás, amikor az adott személy az innovációról (annak létezéséről) információt szerez. A második szakasz a meggyőzés vagy meggyőződés, amikor az illető rendelkezik bizonyos pozitív vagy negatív irányú attitüddel az innováció bevezetésével kapcsolatban. A következő a konkrét döntés, melynek során az érdeklődő eldönti, hogy bevezeti-e az adott innovációt vagy nem. A negyedik szakasz a kivitelezés, amikor az illető elkezdi alkalmazni a már megismert innovációt. S végül a jóváhagyás lépése, amelynek során a személy értékeli a korábbi döntését az innováció bevezetésével kapcsolatban (RogERS, E.M. 1983, SPIL, T.A.M. 2006, ZANABOni, P. - WoOTTON, R. 2012, ZhAnG, X. et al. 2015).

A meggyőzést (2. szakasz) számos tényező befolyásolja, amely meghatározza azt, hogy az illető végül adaptálja-e az adott innovációt. Ilyen többek között a relatív előny, a komplexitás, a kompatibilitás, a megfigyelhetőség és a kipróbálhatóság (RoGERS, E.M. 1983, SPIL, T.A.M. 2006, ZANABOni, P. - WoOtTOn, R. 2012, ZHANG, X. et al. 2015).

A relatív előny azt jelenti, hogy az innováció kedvezőbb feltételeket teremt-e annál, mint amit lecserélnek vele. Amennyiben ez megvalósul, az pozitívan hat annak bevezetésére. A komplexitás az innováció alkalmazásának vélt, vagy valós nehézségét jelöli. Ha az egyszerüen megérthető, bevezethető és használható, az szintén hozzájárulhat az innováció adaptálásához. A kompatibilitás azt jelenti, hogy megvan-e a harmónia az innováció és a már meglévő értékrendszer, bevett gyakorlatok, tapasztalatok között és a szükségleteket képes-e kielégíteni. Amennyiben az a meglévő gyakorlatokba beépíthető és nem igényel teljesen új munkafolyamatokat, annak kedvező hatása van. A megfigyelhetőség lehetővé teszi, hogy 
mások is láthassák az innováció kimenetelét. A kipróbálhatóság pedig azt mutatja meg, hogy van-e mód az innováció tesztelésére. Ez utóbbi kettő is hozzájárul ahhoz, hogy csökkenjen az új technológiát bevezetni kívánó félelme az innovációtól, hiszen megtapasztalhatja annak eredményét (Rogers, E.M. 1983, Spil, T.A.M. 2006, Zanaboni, P. - Wootton, R. 2012, ZHANG, X. et al. 2015).

Az e-egészségügy és azon belül a telemedicina adaptálásában is megfigyelhetők ROGERS innovációs kategóriái, az egyes szakaszok, valamint az azokat determináló tényezők (ZANABOni, P. - WoOtTon, R. 2012, ZhanG, X. et al. 2015).

A különböző távgyógyászati részterületek alkalmazásánál is figyelembe kell venni az új rendszer várható hatékonyságát, amihez megfelelő alapot adhat korábbi sikeres adaptációs példák megismerése. A bevezetésnél a meglévő igények és várható eredményeken túl releváns szerepet kaphat az is, hogy az innováció miként integrálható a klasszikus ellátásba, vagyis a megszokott klinikai rutinba.

Érdemes azt is kiemelni, hogy mennyire innovatívak az egészségügyi szakemberek, (vagy a páciensek) milyen attitüddel rendelkeznek, látnak-e benne potenciált, ugyanis valószínüsíthetően ezek határozzák majd meg, hogy hajlandók lesznek-e a korábbi munkafolyamataikat felülírni azokért az előnyökért, amiket esetleg hozhat a telemedicina. Amennyiben ezek a technológiák nem eléggé felhasználóbarátok, vagyis az alkalmazásukhoz szükséges ismeretek és készségek elsajátítása jelentős energia befektetéssel jár, úgy valószínűsíthetően kisebb az esély azok használatára, tehát az innováció csupán későbbi szakaszokban kerülhet bevezetésre.

\subsection{A technológia elfogadásának elmélete}

A technológia elfogadásának modellje (TAM) FRED DAVIS nevéhez köthető, aki az 1980as években alkotta meg elméletét. Ennek indokoltságát többek között az adta, hogy az egyes munkavállalók kevésbé alkalmazták az infokommunikációs technológiákat a mindennapi tevékenységük során. Ez az elmélet pedig kiválóan alkalmas e technológiák használatának (elfogadásának) megértéséhez, tervezéséhez, amit erősít a modell egyszerű használata és IKT specifikussága (CHEN, SC. - LI, S.H. - LI, CY. 2011, HoLDEN, R.J. - KARSH, BT. 2010, HU, P.J. et al. 1999, PARK, S.Y. 2009, Schaper, L. - PERVAN, G. 2004, SPIL, T.A.M. 2006, Sun, Y. et al. 2013).

A modell két alaptételből indul ki: az egyik az észlelt hasznosság, a másik pedig az észlelt egyszerü használat. Az első azt fejezi ki, hogy az adott illető hogyan ítéli meg a szóban forgó technológia alkalmazásának elönyeit. Amennyiben ez képes növelni a mindennapi tevékenységének hatékonyságát, az kedvezően befolyásolhatja a technológia elfogadását. A másik tétel pedig arra utal, hogy az új technológia alkalmazása nem jár jelentős nehézségekkel, így az könnyen használható, ami szintén pozitív tartalommal bír. Így ez a két tényező határozza meg az illető attitüdjét és szándékát, ami végül a technológia elfogadásának irányába hat (CHEN, SC. - LI, S.H. - LI, CY. 2011, HU, P.J. et al. 1999, HOLDEN, R.J. - KARSH, BT. 2010, PARK, S.Y. 2009, SPIL, T.A.M. 2006, Sun, Y. et al. 2013, ZANABoni, P. WoOtTON, R. 2012).

Az észlelt egyszerü használat determinálja az észlelt hasznosságot, ami annak előzményeként is felfogható. Mindkét tényezőre azonban hatással vannak külső tényezők. DAVIS elméletében meghatározóbb szerepet ad az észlelt hasznosságnak, mint az észlelt egyszerü használatnak, ugyanis álláspontja szerint az előbbi jobban meghatározza a technológia elfogadását és használatát, mint az utóbbi. Továbbá azt is hangsúlyozza, hogy 
fontosabb e két tényező vizsgálata a technológiát alkalmazók szempontjából, mint sem azok tényleges kvantifikálása (CHEN, SC. - LI, S.H. - LI, CY. 2011, SPIL, T.A.M. 2006).

Egyes kutatók szerint ez a modell egy másik teóriához is köthető (lényegében annak továbbfejlesztése), ami nem más, mint az indokolt cselekvés elmélete. Ez utóbbi szintén az egyéni magatartás okainak feltárására és magyarázatára tesz kísérletet, ami alapvetően két tényezőn alapul. Az egyik az attitüd, ami meghatározza az egyén hozzáállását az adott cselekvés esetén, ami lehet pozitív vagy negatív tartalmú. A másik pedig a szubjektív norma, ami visszavezethető a társadalmi nyomásra (mások hogyan vélekednek az adott tényezőről), amely hatással van az egyén döntésére (HoldEN, R.J. - KARSH, BT. 2010, PARK, S.Y. 2009, Sun, Y. et al. 2013).

Annak ellenére, hogy a technológia elfogadásának modellje nem tipikus egészségügyben használatos elmélet, több publikáció igazolta az ágazatban való alkalmazását (HOLDEN, R.J. KARSH, BT. 2010).

Ezt az elképzelést elsősorban az infokommunikációs technológiák általános felhasználói vizsgálták, de kevésbé tesztelték egészségügyi szakembereken, így a szabályok nem feltétlen érvényesek például orvosok tekintetében (HU, P. J. - CHAU, P. Y. K. - SHENG, O. R. L. - TAM, K. Y. 1999, Schaper, L. - Pervan, G. 2004). Egyes kutatók arra is felhívják a figyelmet, hogy az egészségügyi technológiák elfogadásánál nem csupán a technológia használatát szükséges vizsgálni, hanem az egészséggel kapcsolatos magatartást is (SuN, Y. et al. 2013).

A fentiek ellenére a technológia elfogadásának modelljét az egészségügyön belül alkalmazzák a telemedicina használatával kapcsolatos attitüdök vizsgálatára is. Egyik korai példa erre egy hongkongi kutatás, melynek alapja egy 400 szakorvost érintő kérdőíves adatfelvétel. E kutatás eredménye szerint a technológia elfogadásának modellje csak részben alkalmazható az egészségügyben (HOLDEN, R.J. - KARSH, BT. 2010, HU, P.J. et al. 1999, SCHAPER, L. - PERVAN, G. 2004).

Egyes telemedicina használatával kapcsolatos kutatások szerint az észlelt hasznosságnak van meghatározó szerepe, míg az észlelt egyszerű használat jelentősége elenyésző az orvosoknál. Amennyiben tapasztalják a technológia előnyeit, úgy feltehetően kisebb akadályt jelent a kezeléshez szükséges ismeret elsajátítása (Hu, P.J. et al. 1999, Sun, Y. et al. 2013).

Számos oka lehet annak, amiért ez az elmélet kevésbé eredményes az egészségügyben. Talán az egyik éppen abból adódik, hogy az orvosok különbözö szakterületekkel foglalkoznak, és így másként viszonyulnak az infokommunikációs technológiákhoz (HOLDEN, R.J. - KARSH, BT. 2010, HU, P.J. et al. 1999).

$\mathrm{Az}$ újabb e-egészségüggyel kapcsolatos kutatások eredményei ugyanakkor valamelyest felülírják, illetve megcáfolják a fenti gondolatokat. A mobil technológiával támogatott egészségügyi szolgáltatások (m-health) esetében, illetve általában az infokommunikációs technológiák egészségügyi adaptálásánál (vagy annak szándékánál) az észlelet hasznosság mellett jelentős szerepet kap az észlelt egyszerü használat is, csak úgy, mint például az idő, a pénz vagy éppen a betegbiztonság stb. (GAGNON, M.P. et al 2012, 2015).

Egy másik, orvosok körében végzett kérdőíves kutatás eredménye szerint mind az észlelt hasznosság, mind pedig az észlelt egyszerű használat (regressziós elemzés során) jelentős együttmozgást mutat a teledermatológiai adaptálási szándékkal kapcsolatban (ORRUÑO, E. et al. 2011). Feltehetően tehát a technológia elfogadásának mindkét eleme, a hasznosság és a könnyü használat is releváns lehet a távgyógyászat tekintetében. Ugyanakkor az sem hagyható figyelmen kívül, hogy valószínüleg a várható hatékonyság némileg fontosabb a felhasználóbarát kezelésnél. 


\subsection{A tervezett cselekvés elmélete}

A tervezett cselekvés elmélete (TPB) ICEK AJZEN nevéhez köthető és megalkotása az 1980as évekre tehető (AJZEN, I. 1991, SPIL, T.A.M. 2006). Ez a teória szorosan kapcsolható a technológia elfogadásának elméletéhez, hiszen mindkét modell a korábban már felvázolt indokolt cselekvés elméletéböl indul ki, lényegében annak kiegészítése (SuN, Y. et al. 2013).

Az elmélet központi tényezője az a szándék, ami elvezet a tényleges cselekvéshez. Közöttük szoros együttmozgás tapasztalható, ugyanis minél erősebb a szándék, annál nagyobb az adott magatartás bekövetkezésének az esélye. Az elmélet a motiváción kívül hangsúlyozza az egyéni képesség szerepét is, ami szintén a magatartás irányába hat. Természetesen a konkrét cselekvést befolyásolják a különböző lehetőségek és források is, mint például a pénz és az idő (AJZEN, I. 1991, SMITH, J.R. et al. 2007, SPIL, T.A.M. 2006).

A szándékot három tényező határozza meg: az attitüd a viselkedés irányába, a szubjektív norma és az észlelt viselkedési kontroll. A hozzáállás azt jelöli, hogy az illető hogyan minősíti az adott cselekvést: pozitív, vagy éppen negatív irányú attitüdöt tanúsít iránta. A szubjektív norma nem más, mint az a társadalmi nyomás, ami az adott személyen van, hogy szükséges-e végrehajtani az aktuális cselekvést. Az észlelt viselkedési kontroll pedig azt adja meg, hogy mennyire egyszerüen, vagy bonyolultan végezhető el egy cselekvés (ami épít a tapasztalatokra és a különböző akadályokra), valamint az illető képes-e annak megvalósítására. Ez a viselkedési kontroll tehát lényegében nem más, mint az önhatékonyság (AJZEN, I. 1991, SMITH, J.R. et al. 2007, SPIL, T.A.M. 2006).

Az elmélet szerint a szándékból és az észlelt viselkedési kontrollból nagy valószínüséggel meg lehet határozni a cselekvés bekövetkezését. Amennyiben azonban nincsenek meg a cselekvéshez szükséges információk és források, akkor a fentiek sem mutatnak tényleges helyzetet. Olyan esetben, amikor az attitüd, a szubjektív norma és az észlelt viselkedési kontroll is pozitív képet vázol fel, az kedvezö irányt ad a szándéknak, ami végül determinálja a cselekvést. Az egyes magatartások során a három tényezőnek különböző szerepe van a szándék formálásában. Bizonyos esetekben az egyik, más szituációkban a másik rendelkezik nagyobb befolyással a cselekvést meghatározó szándékra (AJZEN, I. 1991, SMITH, J.R. et al. 2007, SPIL, T.A.M. 2006).

A tervezett cselekvés elméletben AJZEN kiemeli a különböző hiedelmek szerepét, amelyek befolyásolják a fentiek során felvázolt tényezőket. Ezek a viselkedési, a normatív és a kontroll hiedelmek. Az első az attitüdre gyakorol hatást, ami arra utal, hogy a cselekvés milyen eredménnyel (pozitív, vagy negatív) zárul. A normatív hiedelmek a szubjektív normát determinálják, amelyek azt fejezik ki, hogy az egyén szempontjából meghatározó társadalmi csoportok hogyan vélekednek az adott magatartásról (ellenzik, vagy nem). A kontroll hiedelmek pedig az észlelt viselkedési kontrollt befolyásolják, ami arra utal, hogy megvannak-e a szükséges erőforrások és a potenciálok a kívánt cselekvéshez (AJZEN, I. 1991, SMITH, J.R. et al. 2007, SPIL, T.A.M. 2006). Ezek a hiedelmek és a modell föbb tételei alapvetően determinálják az egyén szándékát és így a végső magatartást is. Összességében a tervezett cselekvés elmélete egyrészt képes megindokolni és elöre jelezni is az adott cselekvést (AJZEN, I. 1991).

Ugyanakkor a technológiai elfogadás és a tervezett cselekvés modellje sem képes úgy megmagyarázni az egészséggel kapcsolatos viselkedést, mint a védelemmotivációs elmélet (PMT), amelynek elemei szorosan kötődnek a fenti elméletekhez (SUN, Y. et al. 2013). Ez utóbbi különösen alkalmas arra, hogy a betegek szempontjából is megvizsgálja az egészségügyi technológia elfogadását. Az elmélet öt tételen alapul: a válasz hatékonyságán, az önhatékonyságon, a válasz költségén, a vélt sebezhetőségen és a vélt súlyosságon. Ezek közül pedig leginkább a hatékonyságának van meghatározó szerepe az egészségügyi 
technológia elfogadásánál, azonban az egyén döntésének esetleges (észlelt) következményei (annak súlyossága, sebezhetősége) sem hagyhatók figyelmen kívül. Összességében a védelemmotivációs elmélet is az egyén szintjén próbál választ adni az adott magatartásra. Egyes kutatók arra hívják fel a figyelmet, hogy csak a fenti modelleknek (TAM, TPB, PMT) az integrációja adhat kielégítő választ a technológia adaptálásával kapcsolatos viselkedéshez (Sun, Y. et al. 2013).

\subsection{A cselekvőhálózat elmélet}

A cselekvőhálózat elmélet kialakulása az 1980-as évekre tehető, melynek megalkotása a szakirodalom szerint alapvetően BRUNO LATOUR, MiCHAEL CALLON és JOHN LAW nevéhez köthető (Graham, S. 1998, Jóhannesson, G.T. - BAEREnholdt, J.O. 2009, P. Borbély É. 2011, RitZer, G. 2005, SZABARI V. 2007).

A társadalomtudományokban és ezekhez kötődően a társadalomföldrajzban, továbbá annak részterületeiben csak később, az 1990-es évek második felétől jelenik meg. A teória központi témája a társadalmi rend, aminek egyik fő kérdése pedig, hogy miként válik stabillá térben és időben (JÓHANNESSON, G.T. - BAERENHOLDT, J.O. 2009).

Ennek részeként olyan kérdések is érintettek, amelyek a társadalomtudományt általában is foglalkoztatják, mint például: miben különbözik az egyik a másiktól? Hogyan tudott fennmaradni? Ezek a társadalmi rendek azonban az ANT (Actor-Network Theory) szerint egyfajta hatásként értékelhetők, a társadalmi kapcsolatok és hatalmi viszonyokhoz hasonlóan. Ezek a hatások azonban rendkívül bonyolult, heterogén elemekböl felépülö hálózatokban gyökereznek (LAW, J. 1992).

Az elmélet megértéséhez szükséges mindenfajta elöítélet és feltételezés elvetése, vagyis semmit sem szabad magától értetődőnek venni. Ebből adódóan az olyan ellentétpárok, mint a természet és társadalom, vagy lokális és globális között nem kívánatos különbséget tenni (JóHANNESSON, G.T. - BAERENHOLDT, J.O. 2009, LAW, J. 1992). Az elmélet ebben a tekintetben szorosan kapcsolódik a posztstrukturalizmushoz (BoROs L. 2010b, 2012, 2013).

Az ANT szakít azzal a dichotóm szemlélettel, ami „tisztított” kategóriákon (természettársadalom) alapul, aminek köszönhetően egyfajta „középutat” kínál a realizmus és a társadalmi konstruktivizmus között. Az egyes kategóriák minden esetben a kollektív tevékenység hatására jönnek létre (JÓHANNESSON, G.T. - BAERENHOLDT, J.O. 2009, RITZER, G. 2005).

Az elmélet figyelembe veszi és egyenlő szerepet ad az emberi tényezőknek és a nem emberi faktoroknak, hiszen az emberek önmagukban, a hálózatban csupán „meztelen testek”, így csak a hálózat többi „résztvevőjével” vállnak igazi szereplővé (JóHANNESSON, G.T. BAERENHOLDT, J.O. 2009). Ebből adódóan a fizikai valóságot nemcsak emberek, hanem emberi alkotások, különböző anyagok, infrastrukturális elemek, más élőlények és ezek szoros kapcsolata alkotja, ami viszont állandóan változik, vagyis a hálózatokban a nem emberi tényezők is aktív cselekvők (GreENHALGH, T. - STONES, R. 2010, JóHANNESSON, G.T. BAERENHOLDT, J.O. 2009, NÉMEDI D. et al. 2007, SZABARI V. 2007).

$\mathrm{Az}$ ANT szerint a tudás a hagyományos szociológiai szemlélettel ellentétben nem társadalmi produktum, hanem a heterogén hálózat összetevőinek eredménye (LAW, J. 1992). A „társadalmi” mint terminus is problematikus az elmélet szerint, hiszen ez a való világ átfogó, szociológusok által leegyszerűsített definíciója (SZABARI V. 2007).

A teória különös szerepet ad az empirikus vizsgálatoknak, amelyeknek viszont a kapcsolatok feltárásával szükséges, hogy foglalkozzanak. A konkrét cselekvők az ANT szempontjából irrelevánsak, azok tágabb környezetükben, hálózatukkal együtt értelmezendők, 
ugyanis a cselekedeteket több tényező is befolyásolja (JÓHANNESSON, G.T. - BAERENHOLDT, J.O. 2009, LAW, J. 1992, SZABARI V. 2007).

A cselekvőhálózat elméletben a cselekvő egy kapcsolati hatásként értelmezhető egy komplex, hibrid hálózatban, ahol minden összefügg mindennel. A hálózat, mint kifejezés, pedig semmiképpen sem egyeztethetö össze a csomópontok közötti csatornákkal, és ez nem tekinthető sem társadalminak, sem materiálisnak. Ezeket ún. heterogén aktánsok (a hálózat emberi és nem emberi „cselekvői”) alkotják, ennek megfelelően a társadalom része és eredménye is a hálózatépítésnek (JÓHANNESSON, G.T. - BAERENHOLDT, J.O. 2009, LAW, J. 1992). Összességében az ANT ún. szociotechnológiai folyamatként értelmezhető, melynek eredményeként az emberi tényezőt és a technikai faktort egy részhalmazon belül kezeli és közöttük semmiféle hierarchikus kapcsolatot nem feltételez. Egyes esetekben az egyik, más esetekben a másik kap nagyobb szerepet, ugyanakkor az emberi jogi, felelősségi szempontok továbbra sem tagadhatók (GRAHAM, S. 1998, JÓHANNESSON, G.T. - BAERENHOLDT, J.O. 2009, LAW, J. 1992, NÉMEDi D. et al. 2007, RITZER, G. 2005).

Az elmélet lényegében három tételen (heterogenitás, szimmetria és transzláció) alapul, amelyek szorosan kötődnek egymáshoz. A heterogenitás szerint az a valóság, amit megélünk emberi tényezők és nem emberi faktorok alkotják, amelyeknek a szimmetria elve szerint egyenlő szerepük van. A transzláció szerint pedig az emberi tényezők és a technikai faktorok keverednek, átalakulnak és közöttük szoros kölcsönhatás alakul ki (JÓHANNESSON, G.T. BAerenholdt, J.O. 2009, NÉMEDi D. et al. 2007, P. BorbÉly É. 2011, RitZER, G. 2005, SZABARI V. 2007).

A cselekvőhálózat elmélet is érintett a hatalom mechanikájában, azonban a vizsgálat során a gazdagokra ugyanúgy kell tekinteni, mint a szegényekre és hasonlóan kell elemezni öket. Ez természetesen nem jelenti azt, hogy az elmélet a gazdagok hatalmát nem ismerné el, hiszen a szociotechnológiai hálózatban ugyanúgy megjelenik a centrum-periféria reláció és a hegemónia (LAW, J. 1992, RITZER, G. 2005). Az ANT egyik kritikai bírálata ehhez kapcsolódóan abban rejlik, hogy nem mindig egyértelmü az egyes munkákban a hatalom és az elnyomás kérdése. Ezenfelül meghatározó az a kritikai szempont is, miszerint az elmélet túl nagy hangsúlyt fektet a változékonyságra, a fluiditásra (JÓHANNESSON, G.T. - BAERENHOLDT, J.O. 2009).

A földrajz az 1990-es években kezd a cselekvőhálózat elmélet felé fordulni, melynek eredményeként fokozatosan eltünnek az olyan ellentétpárok, mint a természet és a társadalom. Ez elsősorban annak tudható be, hogy a korábbi, előzőekben ismertetett dichotóm kategóriák közötti határvonal fokozatosan halványodik, amit olyan komplex környezeti-földrajzi problémák is segítenek, mint például a globális felmelegedés (JóHANNESSON, G.T. BAERENHOLDT, J.O. 2009).

Az ANT azonban elsősorban a gazdaságföldrajzi kutatásokban hódít és a hangsúly azon van, hogy a társadalmi-gazdasági kapcsolatok hogyan alakítják a piacgazdaság térbeli szerkezetét. Az elmélet ugyanakkor alapvetően másfajta hálózatot támogat, mint ami a gazdaságföldrajzban is elfogadott, hiszen az ANT elveti a lépték kérdését és nem tesz érdemi különbséget a lokális és globális tényezők között. Ennek megfelelően a helyek kapcsolati eredményként és nem fix pontként értelmezendők és ehhez hasonlóan a piacok is hálózati folyamatok eredöi (JÓHANNESSON, G.T. - BAERENHOLDT, J.O. 2009).

Az elmélet központi eleme a tér és az idő, azonban az abszolút és a hagyományos értelemben vett geometriai tér nem értelmezhető. A tér, mint relációs folyamat átértékeli a távolság fogalmát is, amit a hálózatokban lévő elemek közti kapcsolatok határoznak meg, és aminek köszönhetően egyes esetekben a „közelség” sokszor nagyobb fizikai távolságra is utalhat. A cselekvőhálózat elmélet így topológiai modellben gondolkodik, hiszen ez képes 
megmutatni a közelséget és távolságot a kapcsolati terekben (GRAHAM, S. 1998, JÓHANNESSON, G.T. - BAERENHOLDT, J.O. 2009).

Az 1990-es évektől kezdve a cselekvőhálózat elméletet hasznosítása egyre inkább előtérbe kerül az információs és kommunikációs technológiák hatásainak vizsgálatakor (P. BORBÉLY É. 2011). Ebből adódóan az ANT alkalmazható a telemedicinára is, hiszen ez az ellátási forma is az infokommunikációs technológiákon alapul. A cselekvőhálózat szociotechnológiai hálózatként értelmezhető, melynek köszönhetően az emberi tényezők és a technikai elemek keverednek (GRAHAM, S. 1998, RITZER, G. 2005).

Ehhez hasonlóan a telemedicina különböző formáiban is kapcsolatba kerülnek egymással. A távkonzíliumnál és a távdiagnosztikánál az egészségügyi szakemberek között az információ és adatcsere internetkapcsolaton keresztül valósul meg. A távfelügyelet esetében pedig a betegnél lévő felügyeleti eszköz küldi az adatokat egy adatbázisba, ami történhet automatikusan, vagy emberi „,beavatkozás” hatására (FICZERE A. 2010a, 2010b).

A szociotechnológiai hálózat az infokommunikáció fejlődésével párhuzamosan egy újfajta interakciót teremt meg az emberek között (GRAHAM, S. 1998). Ez a reláció a távgyógyászat esetében is megjelenik, hiszen a fizikai kontaktust egy virtuális, telekommunikáción keresztül biztosított kapcsolat váltja fel egészségügyi szakemberek és páciensek között is.

Összességében tehát a távközlési technológiák és a különböző technológiai vívmányok szoros kapcsolatba kerülnek az emberekkel, melynek eredményeként a határ ember és gép között fokozatosan halványodni kezd (lásd távfelügyelet) és létrejön az ún. „,kiberorganizmus”. Értelmét veszti önmagában gépről vagy emberről beszélni, hiszen szoros, bonyolult kapcsolat jön köztük létre és hálózatot alkotnak (GRAHAM, S. 1998).

A telemedicina tekintetében a hibrid hálózat elemei is igen sokrétüek: orvosok, egészségügyi asszisztensek, technikusok, betegek, egészségügyi intézmények, technikai berendezések, és azok gyártói, amelyek folyamatos kapcsolatban vannak egymással. Nem önmagában egy-egy résztvevő cselekedetei számítanak, hanem a teljes telemedicinális hálózat effektusai. Általában fontos megteremteni a harmóniát a hálózatot alkotók között, hiszen csak ez biztosítja a hosszú távú működést (P. BORBÉLY É. 2011). Ennek megfelelően szintén releváns lehet a telemedicinális hibrid kapcsolatoknál is a zökkenőmentesség fenntartása, vagy az arra való törekedés. Abban az esetben, ha hosszú távú feszültség és konfliktus indukálódik a távgyógyászat esetében a hálózat elemei között (pl. orvos és új korszerü technika alkalmazhatósága), az hozzájárulhat a hálózat megszünéséhez.

Az előzőeken túl érdemes azt is kiemelni, hogy nem csak egyetlen heterogén hálózat létezik, hanem párhuzamosan több is, így ezek kapcsolatba kerülhetnek egymással. Az összekapcsolt telemedicinális hálózatok pedig feltehetően hatással vannak egymás müködésére. Ezt erösíti az is, hogy a szociotechnológiai hálózat lokális és nem lokális kapcsolatokon alapul (GRAHAM, S. 1998, LAW, J. 1992).

\subsection{A strukturációs elmélet}

ANTHONY GIDDENS strukturációs elmélete az 1970-es és az 1980-as évekre vezethető vissza, ami a társadalomtudományokban az elméleti és empirikus kutatást egyaránt támogatja, és amiben kiemelt szerepet kap az interdiszciplinaritás. Különös hangsúlyt fektet a társadalmi jelenségek térbeli vonatkozásaira is, ezáltal kiváltva a geográfusok széles érdeklődését is (LIPPUNER, R. - WERLEN, B. 2009).

Az elmélet a kettőség elvén alapul, ami abban mutatkozik meg, hogy a társadalmi struktúrákat emberi tevékenység hozza létre, azonban a struktúrák egyfajta eszközei és keretei is ennek. A társadalmi struktúra és az emberi tevékenység között nincs hierarchikus kapcsolat, nem áll az egyik a másik felett (GIDDENS, A. 1984, 2008, GREENHALGH, T. - STONES, R. 2010, 
Groves, P.S. - Meisenbach, R.J. - Scott-Cawiezell, J. 2011, Jones, M.R. - Karsten, H. 2008, Lehoux, P. et al. 2002, LipPuner, R. - Werlen, B. 2009, McPhee, R.D. - PoOle, M.S. - IVERSON, J. 2014, SADAN, E. 2011, SiK D. 2013).

A társadalmi praxisnak két különböző vetületeként tartják számon, vagyis a struktúra a társadalmi gyakorlat közege és eredménye is egyben. GIDDENS szerint azonban csak az emberek rendelkeznek tudattal, a struktúrák nem, ezáltal a struktúrák nem is cselekednek. A társadalmi élet társadalmi praxisokon keresztül jön létre, míg ezek a társadalmi gyakorlatok emberi tevékenységeken, kapcsolatokon alapulnak. Ráadásul ezeket nem egyes sajátos tevékenységként értékeli, hanem mint áramlási folyamatokat, amelyeknél figyelembe kell venni az okot, szándékot, következményt stb. GIDDENS szerint nem csak azok a cselekedetek fontosak, amelyek szándékosan történtek, és ehhez kapcsolódóan sokszor nehéz elkülöníteni a tevékenységeket szándékosság alapján (GIDDENS, A. 1984, 2008, GROVES, P.S. Meisenbach, R.J. - Scott-Cawiezell, J. 2011, Jones, M.R. - Karsten, H. 2008, LipPunER, R. - Werlen, B. 2009, MCPheE, R.D. - PoOle, M.S. - IVERSON, J. 2014).

A cselekedetek következményeinek vizsgálata mindig lényeges, hiszen külön szempontként jelenik meg a reflexivitás az egyes tevékenységeknél. GIDDENS a tudat három szintjét különbözteti meg, melyben az első a diszkurzív tudat, amivel a cselekedett megmagyarázható verbálisan, úgymond ellenőrizhető és reflexív. A gyakorlati (praktikus) tudathoz a mindennapi, rutin jellegü tevékenységek tartóznak és a cselekedet racionalizálása köthető. A harmadik a tudattalan, vagy tudatalatti, ami nem elérhető a cselekvő számára, hiszen azt nem képes „elöhozni” (GIDDENS, A. 1984, 2008, GROVES, P.S. - MEISENBACH, R.J. - Scott-Cawiezell, J. 2011, Jones, M.R. - Karsten, H. 2008, LehouX, P. et al. 2002, Lippuner, R. - Werlen, B. 2009, McPheE, R.D. - PoOle, M.S. - IVERSON, J. 2014, SiK D. 2013).

A társadalmi valóságot struktúrák alkotják, amelyek viszont nem azonosíthatók csoportokkal, vagy szervezetekkel és nem köthetök külső tevékenységekhez sem, vagyis a struktúrák nem determinisztikusak. A szerkezetek értelmezése két aspektusból, szabályokból és forrásokból történik (GIDDENS, A. 1984, 2008, GROVES, P.S. - MEISENBACH, R.J. - SCOTTCAWiezell, J. 2011, Jones, M.R. - Karsten, H. 2008, LehouX, P. et al. 2002, LiPPUnER, R. - Werlen, B. 2009, McPhee, R.D. - Poole, M.S. - IVerson, J. 2014, SADAN, E. 2011).

GIDDENS szerint a szabályok a tevékenységek áramlásának technikai biztosítékai. A társadalmi gyakorlatoknak nem csak szabályozó karakterük, hanem konstitutív jellegük is ismert. Ezek a szabályok ugyanakkor megjelennek a mindennapi tevékenységeknél „alkalmazott” gyakorlati tudatnál. A forrás terminus nem egyenlő az erőforrás fogalmával, ami GIDDENS értelmezése szerint nem más, mint az emberek és tárgyak feletti hatalom, és amely végül is a társadalmi kapcsolatok és interakciók eleme. A szociális rendszerek pedig a cselekvők és a közösségek közötti társadalmi kapcsolatokként és hálózatokként jönnek létre (Giddens, A. 1984, 2008, Groves, P.S. - MeisenbaCH, R.J. - ScOTT-CAWIEZELl, J. 2011, Jones, M.R. - KARSTEN, H. 2008, LiPPuner, R. - Werlen, B. 2009, MCPheE, R.D. - PoOle, M.S. - IVERSON, J. 2014).

A strukturációs elmélet különös figyelmet fordít a társadalmi gyakorlatok tér és időbeli aspektusaira is. Az elméletekben a szociológia sokszor figyelmen kívül hagyja a térbeli vonatkozásokat. GIDDENS újra felfedezi Hägerstrand időföldrajzát, miszerint a mindennapi élet tér-idő keretek között értelmezhető. Az interakciók bizonyos helyekhez köthetők. A strukturációs elmélet azonban a ,hely” helyett a „helyszín” (locale) terminust használja, ugyanis ez utóbbi speciális jelentéssel bír, ami tükröződik a cselekvők interakcióiban. Ennek megfelelően GIDDENS felosztja a teret kedvező és kedvezőtlen helyzetben lévő egységekre, minden térbeli léptéket érintve (GIDDENS, A. 1984, 2008, LIPPUNER, R. - WERLEN, B. 2009). 
Az elmélet alapvető kritikája egyrészt, hogy a cselekvők túlságosan individualista szereplőként jelennek meg, másrészt GIDDENS a teret adottként és abszolútként értelmezi, amit időnként befolyásol az emberi tevékenység (GIDDENS, A. 1984, 2008, LIPPUNER, R. WERLEN, B. 2009).

A társadalmi struktúrák szabályokon, forrásokon és technológiákon alapulnak, amelyek az idővel változnak, és amik egyrészt megkönnyíthetik a társadalmi interakciókat, másrészt akadályoztathatják azokat. A társadalmi rutinok pedig hozzájárulnak az egyes szereplők szorongásának csökkentéséhez és önbecsülésük növeléséhez. A fentebb már ismertetett három tudati szint (diszkurzív, gyakorlati és tudatalatti) továbbá befolyásolja az emberi tevékenységeket, vagyis ezek a szintek és az előzőekben felsorolt tényezők alapvetően meghatározzák, hogy az adott cselekvő részt vesz-e valamilyen tevékenységben, alkalmaz-e valamilyen technológiát, mint például a telemedicinát (LEHOUX, P. et al. 2002).

Az előzőek figyelembe vételével egy tanulmány fö kérdése, hogy miként integrálható a telemedicina a klinikai rutinba? Erre egy sajátos modell adja meg a választ, miszerint az orvosok szükségletei és igényei meghatározzák azokat a korlátokat és lehetőségeket (ami a szerkezet kettőségéből fakad), amelyek a távkonzultáció használata során születnek (pl. távoli specialisták rendelkezésre állása). Maga a távkonzultáció klinikai gyakorlatba való integrációját számos tényező befolyásolja, melyben jelentős szerepet kap a társadalmi és technikai elfogadottság. Ez egyrészt azt jelöli, hogy a társadalom tagjai mennyire preferálják a távgyógyászati ellátási formákat, másrészt hogy milyen mértékben adott a felhasználóbarát technikai környezet. Amennyiben megtörténik az integráció, úgy az orvosoknak módosítaniuk kell a már meglévő szociális és klinikai rutinokat (LEHOUX, P. et al. 2002).

A társadalmi szabályok és források alapvetően determinálják tehát a telemedicina alkalmazását. Ebben a tekintetben releváns lehet az egészségügyi ellátás helyzete, továbbá a társadalmi elvárás és attitüd (betegek és orvosok esetében egyaránt), illetve a rendelkezésre álló technológia és egyéb források. Ezek azok a tényezők, amelyek hozzájárulnak a távgyógyászat adaptálásához vagy éppen elutasításához.

Összegzésként elmondható, hogy a fenti elméletek különböző léptékben közelítik meg a telemedicina, illetve általában az infokommunikációs technológiák, innovációk adaptálását, használatát, valamint terjedését. A strukturációs és a cselekvőhálózat elmélet az egész társadalom müködését magyarázza, míg a többi egy adott társadalmi jelenséggel foglalkozik. Ennek ellenére rámutatnak arra, hogy az adaptációs folyamatot sok tényező befolyásolja.

GIDDENS szerint a rendelkezésre álló források és szabályok alapvetően kijelölik a lehetőségeket és korlátokat adott társadalmi tevékenység során. A cselekvőhálózat elmélet rávilágít arra, hogy a hálózat heterogén elemeinek a harmonikus, összehangolt müködése elengedhetetlen a sikeres adaptációhoz. A további elméletek (innovációs elmélet, technológia elfogadása, tervezett cselekvés) nagy hangsúlyt fektetnek az egyén attitüdjén felül a technológia hasznosságának (hatékonyságának), egyszerü használatának, a rendelkezésre álló forrásoknak, a szükséges képességek meglétének, a társadalmi normáknak, a tapasztalatoknak stb., amelyek befolyásolhatják a már meglévő szándékot, ami végül elvezethet a tényleges cselekvéshez.

A disszertáció elsősorban pozitivista megközelítésből vizsgálja a folyamatokat, azonban a magyarázatoknál az előzőekben ismertetett elméletekből (cselekvőhálózat, GIDDENS strukturációs elmélete stb.) is merít, illetve reflektál rájuk a következő alfejezetek részösszegzéseiben. 


\section{A kutatás eredményei: a telemedicina és az egészségügy néhány térbeli- társadalmi kérdései Magyarországon}

A disszertáció előző fejezeteiben felvázolt elméleti keret bemutatását követően jelen részben az empirikus eredmények ismertetésére törekszem. Ennek feldolgozása során a dolgozat elején feltett (al)kérdések tematikus megválaszolására teszek kísérletet.

\subsection{A telemedicinát alkalmazó egészségügyi szolgáltatók néhány egészségföldrajzi aspektusa egy kérdőíves felmérés alapján}

Az empirikus kutatás kiindulópontját a magyarországi telemedicinális ellátás területi mintázatának vizsgálata jelenti. Ehhez egy online kérdőíves adatfelvétel adja az alapot - a módszertani fejezetben leírtaknak megfelelően - ami egy területi adatbázis létrehozását szolgálja. Ez az adatállomány azokat - az Országos Egészségbiztosítási Pénztárral (jelenleg: Nemzeti Egészségbiztosítási Alapkezelö) szerződésben álló - a magyarországi egészségügyi szolgáltatókat tartalmazza, amelyek telemedicinával foglalkoznak.

Az adatfelvétel összesen 254 db szolgáltatót érint. Ebből 108 foglalkozik telemedicinával, ami 42,5 százaléknak felel meg (2. táblázat).

\section{2. táblázat: Az egészségügyi szolgáltatók távgyógyászat szerinti megoszlása}

\begin{tabular}{|c|c|c|c|c|c|c|}
\hline Egészségügyi & \multicolumn{2}{|c|}{ Intézmény } & \multicolumn{2}{c|}{ Vállalkozás } & \multicolumn{2}{c|}{ Összesen } \\
\cline { 2 - 7 } szolgáltatók & $\mathbf{d b}$ & $\boldsymbol{\%}$ & $\mathbf{d b}$ & $\mathbf{\%}$ & $\mathbf{d b}$ & $\%$ \\
\hline $\begin{array}{c}\text { Telemedicinát } \\
\text { nem alkalmazó }\end{array}$ & 120 & 56,1 & 26 & 65 & 146 & 57,5 \\
\hline $\begin{array}{c}\text { Telemedicinát } \\
\text { alkalmazó }\end{array}$ & 94 & 43,9 & 14 & 35 & 108 & $\mathbf{4 2 , 5}$ \\
\hline Összesen & 214 & 100 & 40 & 100 & 254 & 100 \\
\hline
\end{tabular}

Ez az arány intézményi szinten kissé magasabb, ugyanakkor vállalkozói szinten valamelyest alacsonyabb. Az eredmények szerint, ha a szolgáltatóknak nem is a többsége, de jelentős hányada - a finanszírozási nehézségek ellenére - kapcsolatba került a telemedicinával az ellátás során (BÁN A. 2014b). (Ez természetesen nem feltétlen jelenti azt, hogy az adott egészségügyi intézmény, vagy vállalkozás távgyógyászati szolgáltatást biztosít, csupán egy telemedicinális interakcióban való részvételt jelöl.)

A távgyógyászattal érintett szolgáltatók 74 településen találhatók, és viszonylag szórtan helyezkednek el az országban. Ugyanakkor a településhálózati sajátosságból fakadóan az Alföldön, azon belül is különösen a Dél-Alföldön figyelhető meg egyfajta koncentráció, míg a Dunántúl városhiányos térségeiben kevésbé találhatók sürüsödési pontok. A szolgáltatók között megyei kórházak, klinikák és köztük újonnan felújított, korszerüsített járóbetegszakellátók is megfigyelhetők. Tehát nem csupán a magasabb progresszivitási szintü intézmények képviseltetik magukat, azonban a szolgáltatók számát figyelembe véve általában a megyeszékhelyek emelkednek ki, ahol többek között megyei oktató kórházak és klinikák is megjelennek (pl. Miskolc, Debrecen, Szolnok, Pécs, Kaposvár, Veszprém). A fóváros kiemelt szerepet kap, hiszen $25 \mathrm{db}$ egészségügyi szolgáltató érintett a telemedicinális ellátásban (10. $a ́ b r a)$. Nagyobb léptékben Pest megyében található koncentrálódás, azon belül is a Budapesti Agglomeráció térségében, ami feltehetően a nagy múltú, magasabb progresszivitású intézmények közelségéből, valamint a népesség nagyfokú koncentrációjából, és így a potenciális ellátandó betegek jelentős számából fakad. Ezenkívül pedig még Borsod-AbaújZemplén megyében figyelhető meg „sürüsödés”, ami valószínüleg az orvoshiánynak és azon belül is különösen a radiológus hiánynak tudható be. Érdekes módon Nógrád megyében a 
kutatás szerint egyetlen szolgáltató sem képviseli a telemedicinával egybekötött ellátást, ami feltehetően inkább a módszertanból fakadó hiátusnak köszönhető, és vélhetően nem a tényleges helyzetképet mutatja.

\section{0. ábra: A telemedicinát alkalmazó szolgáltatók területi megoszlása Magyarországon}

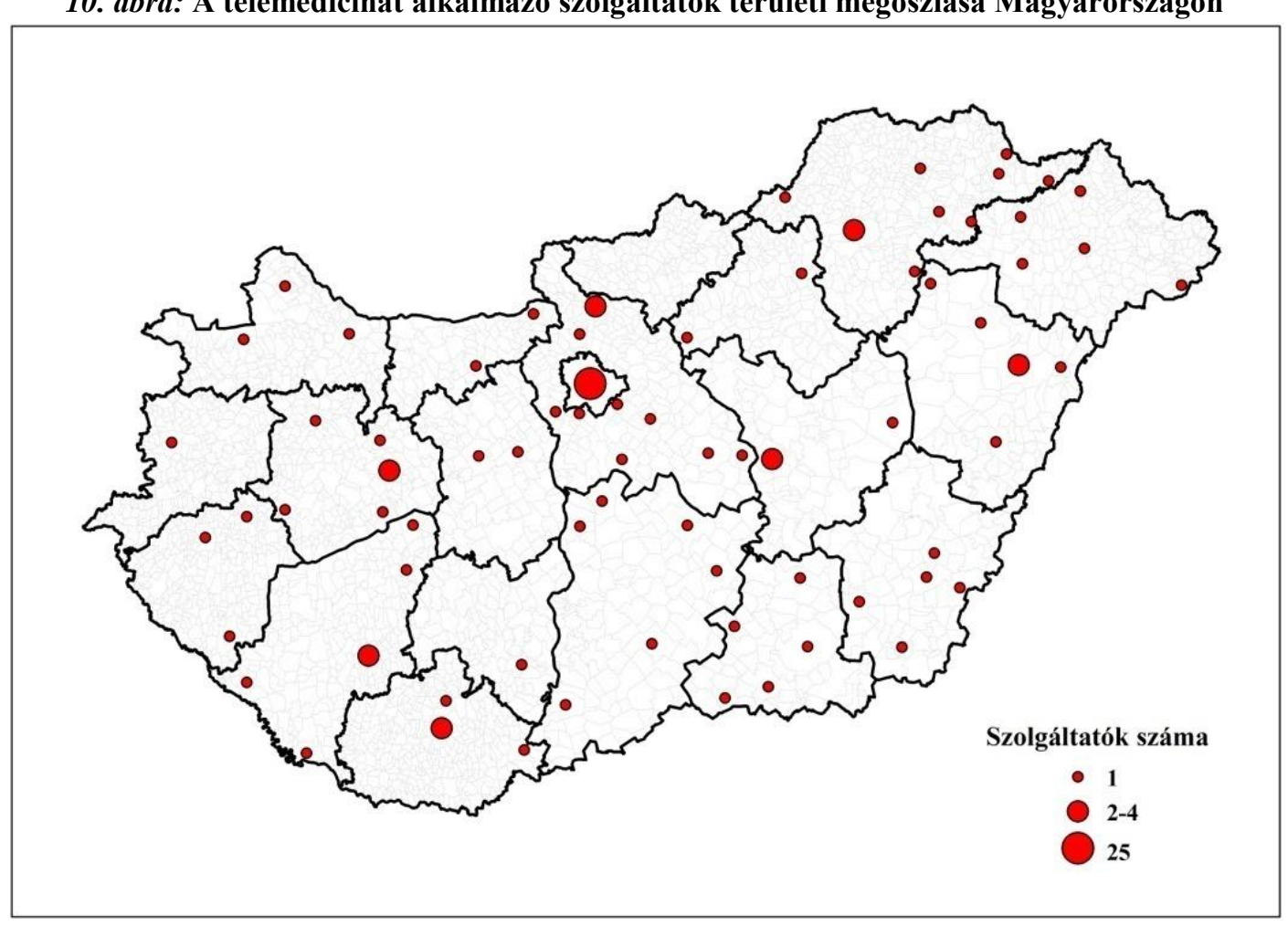

A telemedicina alkalmazásának időbeli megoszlását tekintve igen megosztott a kép. Valamivel kisebb arányban szerepelnek azok a szolgáltatók, akik újonnan, az elmúlt 1-2 év során vezették be ezt az ellátási formát. Míg azok az intézmények, akik 3-5 éve, és azok, akik több mint 5 éve foglalkoznak telemedicinával a válaszadók felét adják (11. ábra).

11. ábra: A telemedicina alkalmazásának időbeli megoszlása 95 válasz alapján

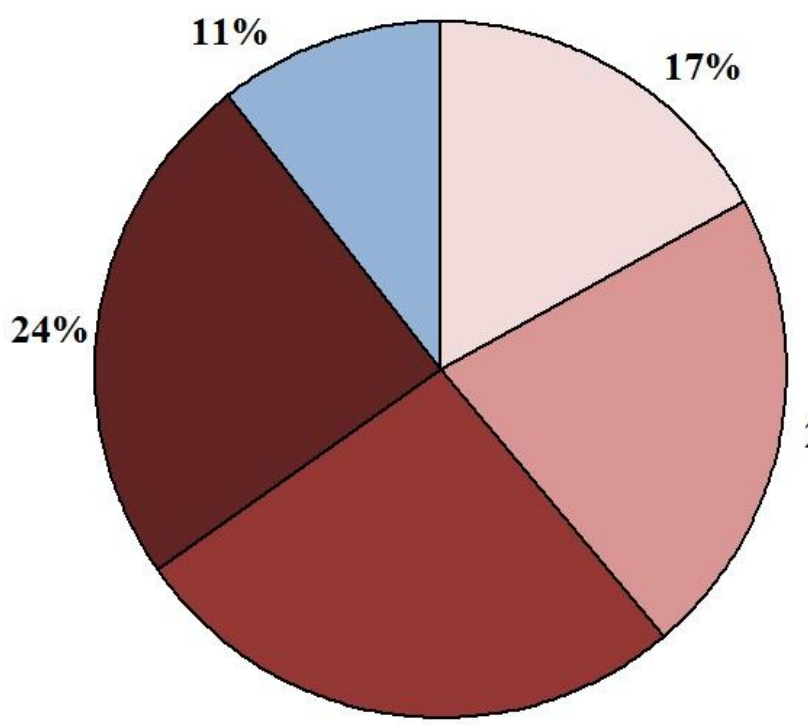

Kevesebb, mint 1 éve 
A szolgáltatók jelentős hányada már évek óta alkalmazza a távellátást és esetükben már nem innovációként jelenik meg, hanem sokkal inkább bevett gyakorlatként. Ez különösen igaz lehet a teleradiológiai szolgáltatásokra, hiszen a távleletezés az egészségügyi intézmények jelentős részében rutin tevékenységnek számít.

További fontos kérdés az is, hogy az egyes szolgáltatók (milyen kapcsolatok vonatkozásában) mit tartanak telemedicinának. A szakirodalom szerint az orvos-orvos és az orvos-beteg közötti, fizikai távolságot áthidaló kontaktus egyaránt telemedicinának tekinthető (FICZERE A. - KÖDMÖN J. 2011). A válaszadók közel kétharmada szerint is az egészségügyi szakemberek, továbbá a páciens és az ellátó közti kapcsolat is a távgyógyászat fogalomkörébe tartozik (12. ábra). Ugyanakkor kétszer akkora azoknak az aránya, akik az orvosok közötti kapcsolatot azonosítják a telemedicinával az orvos-beteg kapcsolattal ellentétben.

12. ábra: A telemedicinális kontaktusokkal kapcsolatos attitüdök megoszlása 205 válasz alapján

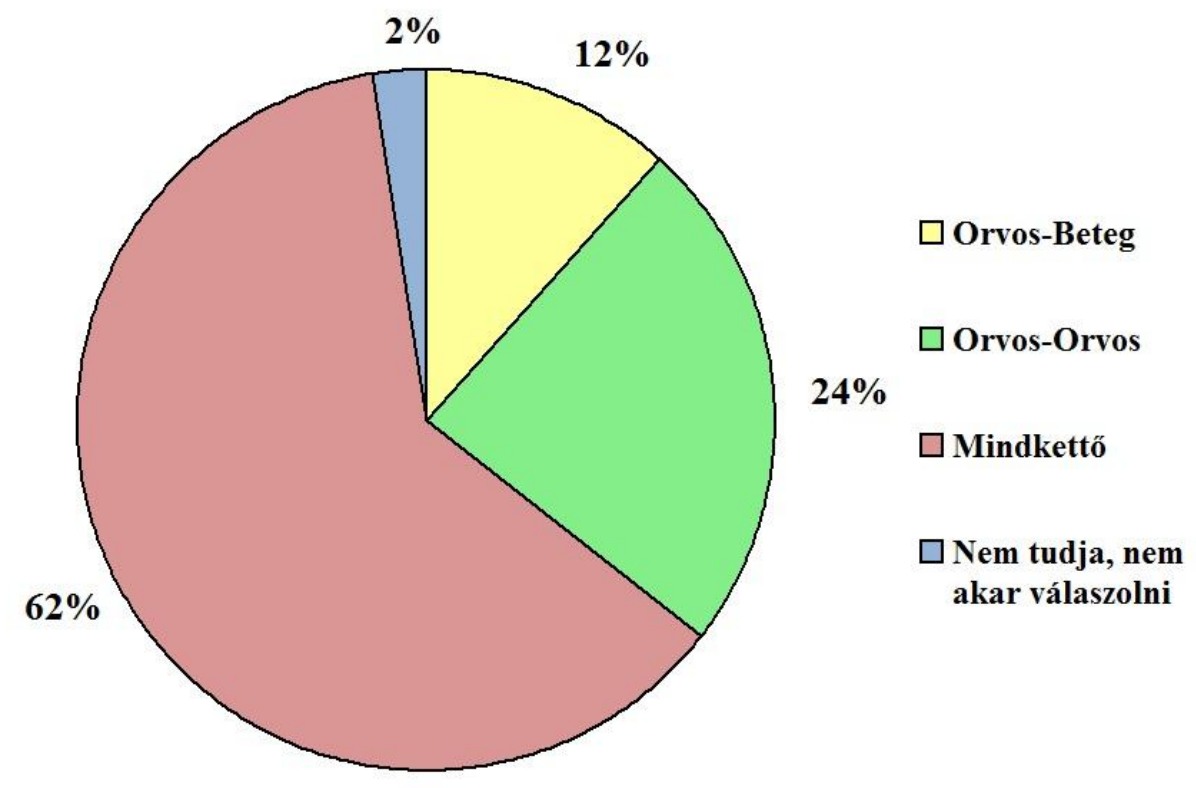

Ez feltehetően annak köszönhető, hogy hazánkban a telemedicina fogalma elsősorban az egészségügyi szakemberek közötti diagnosztikai képek küldésében és értékelésében merül ki. Így lényegében az orvos sokkal inkább a beteg egészségügyi adataival és leletével kerül kapcsolatba, és nem magával a pácienssel. A legtöbb esetben a betegeket általában nem vonják be a távellátásba, hiszen a nyugati mintákkal ellentétben (LEVERT, D. 2010) a háziorvos és a szakorvos közötti videokonferenciás konzíliumokhoz szükséges források nem állnak rendelkezésre. A távfelügyelet pedig sokszor fizetős szolgáltatásként jelenik meg, ami miatt nem túlságosan elterjedt (FICZERE A. 2010a, 2010b).

Az egészségügyi szakemberek közötti telemedicinális kapcsolatok megvalósulhatnak adott intézményen belül, annak orvosai között. Létrejöhet hazai intézmények között is, amikor egy adott intézmény más hazai intézménnyel veszi fel a kapcsolatot, és kialakulhat hazai és külföldi intézmények között is (13. ábra).

A nemzetközi távgyógyászati szolgáltatások nyújtása, vagy éppen igénybevétele, ami nagy távolságot feltételez, hazánkban elenyésző számú ( 9 szolgáltató). Általában - de nem kizárólagosan - a magasabb progresszivitású, és az egészségügyi hierarchia csúcsintézményei közé tartozókat érinti. A települések közti kapcsolatot feltételező második típus adja a legtágabb csoportot, ami leginkább a megfelelő szakemberhiányban jelentkező egészségügyi egyenlőtlenség konzerválódását hivatott mérsékelni (BÁN A. 2014b). 


\section{3. ábra: Az egészségügyi szakemberek között megvalósuló távellátási kapcsolatok típusai}

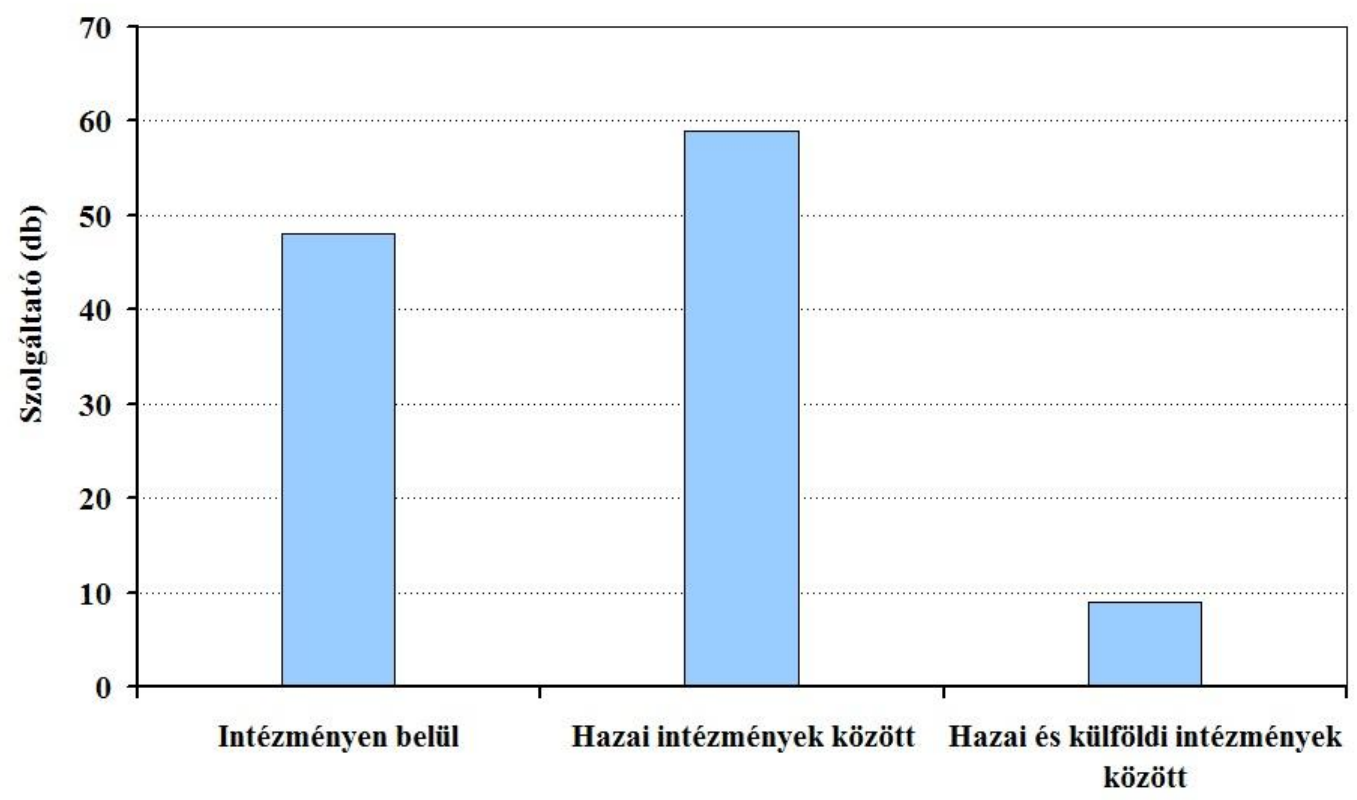

Összességében tehát a településközi távellátási kapcsolatok a meghatározóak, ugyanakkor ettől alig maradnak el a sok esetben szintén az orvoshiány területi csökkentését elösegítő, vagy éppen a hatékonyabb és nemegyszer rugalmasabb munkarendet (pl. otthonról leletezö radiológus) támogató intézményen belüli távgyógyászati kapcsolatok. A telemedicinális kontaktusok tekintetében meglehetősen kiegyenlített a kép, vagyis azok az egészségügyi intézmények, akik távgyógyászati szolgáltatást biztosítanak másoknak (26 szolgáltató), vagy igényelnek másoktól (24 szolgáltató), továbbá azok, akik mindkettőben érintettek nagyságrendileg hasonló számban szerepelnek (30 szolgáltató).

A telemedicina részterületei közül a távdiagnosztika túlsúlya meghatározó, közel 90 szolgáltatóval (14. ábra).

14. ábra: A telemedicina részterületeinek gyakorisága

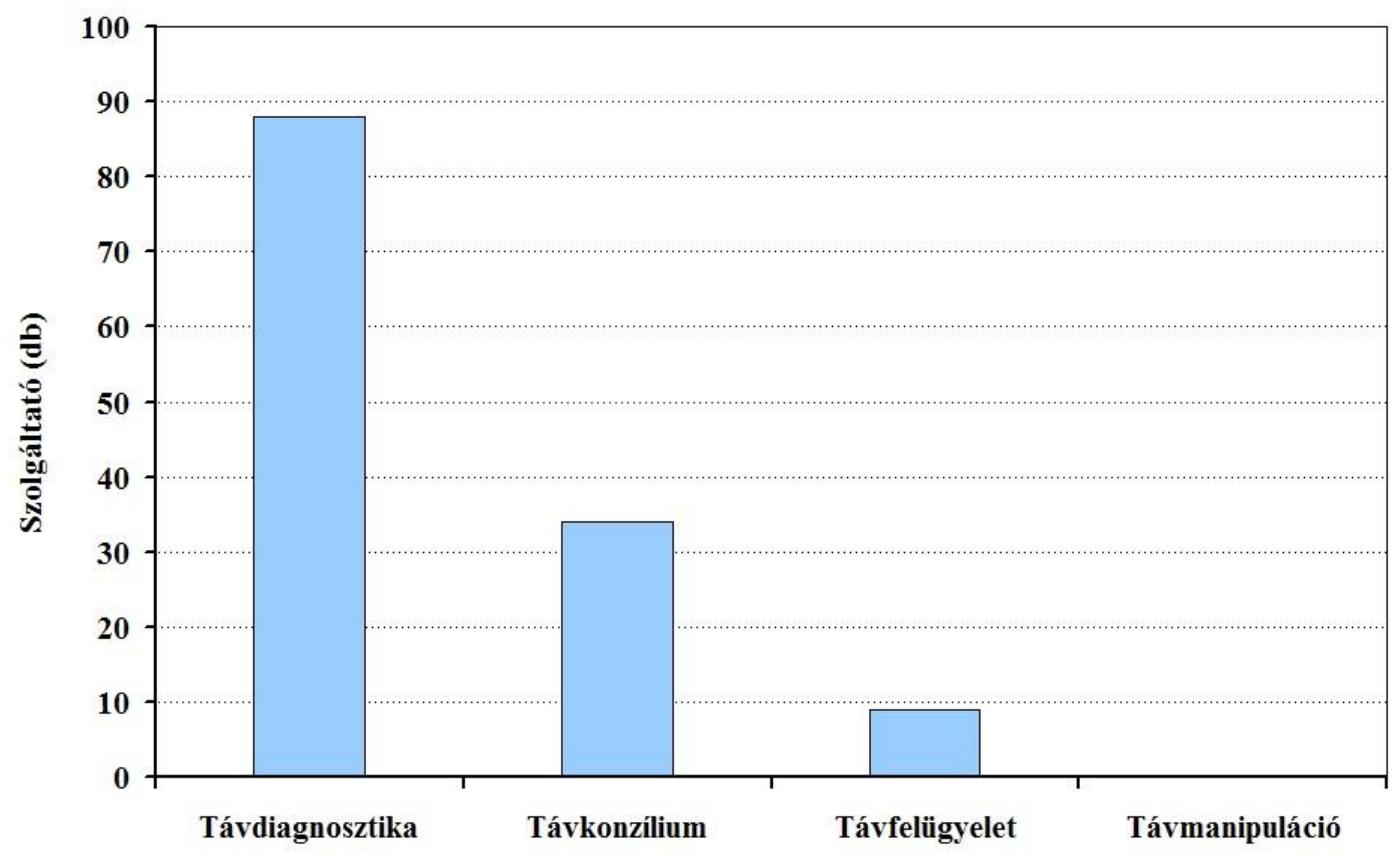


Ebben az esetben a szakorvosok különböző digitális képeket (RTG, CT, MR) értékelnek ki. Ehhez szorosan kapcsolódik a konzílium, hiszen az esetlegesen felmerülő kérdések megvitatására ad alkalmat, aminek lehetőségét az infokommunikációs technológiák teremtik meg az egyszerü telefonos konzultációktól a kiváló minőségü képet és hangot garantáló videokonferenciás kapcsolatokig. A távfelügyelet viszonylag elenyésző szolgáltató érint, míg manipulációt, tehát távérzékelők segítségével történő beavatkozást (lásd Egészségtudományi Fogalomtár [3]) nem végeznek hazánkban a kutatás szerint (BÁN A. 2014b).

Az orvosi szakterületek közül a radiológiának van kulcsszerepe a diagnosztikai képek távleletezése miatt, ami közel 70 szolgáltatót érint (15. ábra). Ezenfelül a telemedicinát használják még a belgyógyászatban, kardiológiában, sebészetben stb., ami szintén kapcsolatba hozható a digitális képalkotással, illetve az első két szakterület esetében a távfelügyeletnek, és így a különböző egészségügyi paraméterek távoli kontrollálásának van jelentősége.

A nemzetközi szakirodalom szerint is a teleradiológia a telemedicina legfejlettebb ága. Ezenkívül a telepatológiának és a teledermatológiának van nagyobb elismertsége (WHO 2010, ZANABONI, P. - WoOTTON, R. 2012), ugyanakkor hazánkban ezek már nem kapnak olyan nagy szerepet az eredmények alapján.

15. ábra: A telemedicina gyakorisága szakterületek szerint

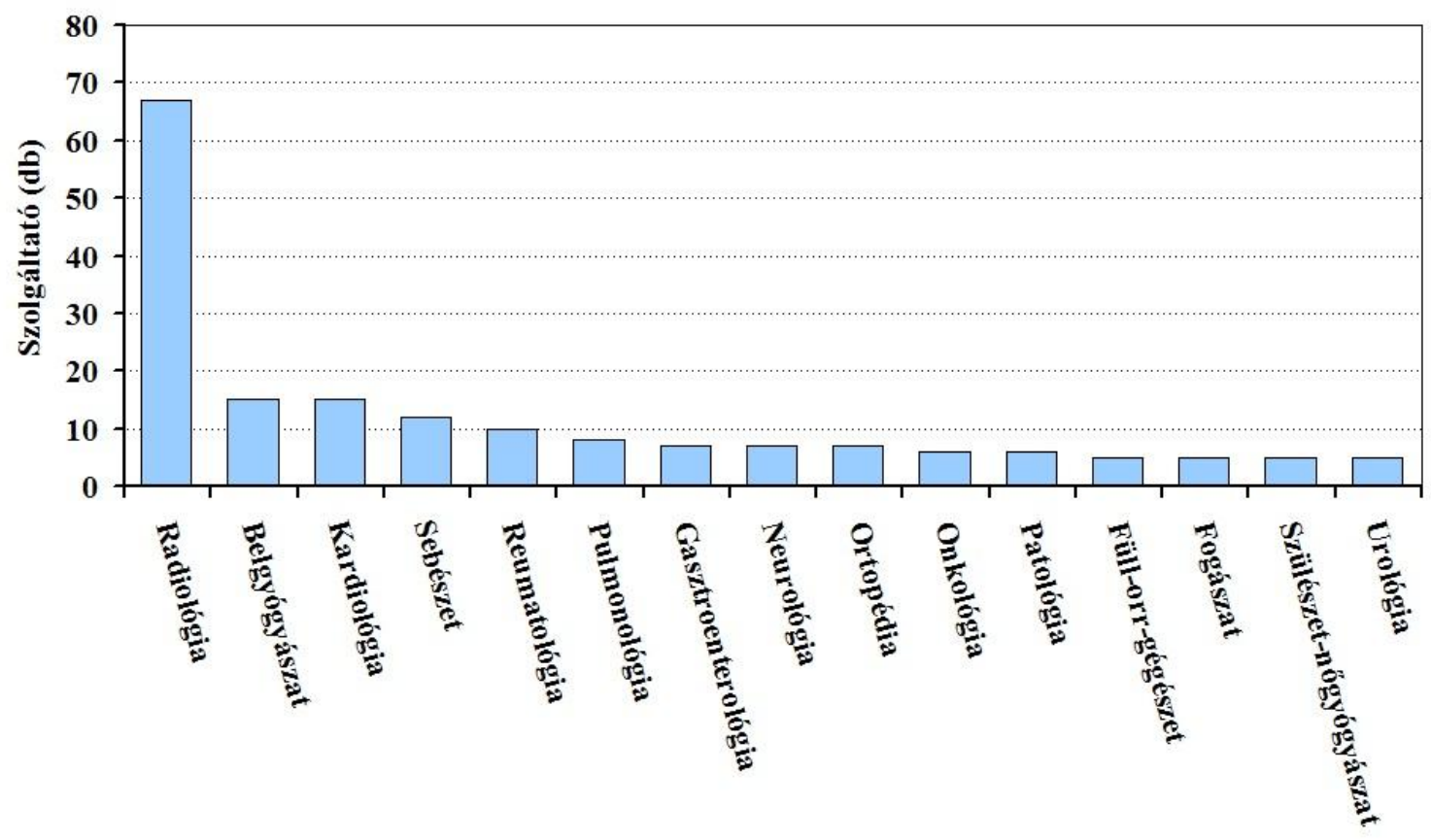

A teleradiológia dominanciája mellett azonban a legtöbb orvosi szakterület képviselteti magát a távgyógyászatban, azonban feltehetően jelentős átfedések vannak a digitális képalkotással és leletezéssel kapcsolatban. Noha a gyakoriságot szemléltető diagram csupán a legtöbbször megjelölt területeket ábrázolja, elökerülnek olyanok is, mint például a szemészet, pszichiátria, gyermekgyógyászat, dermatológia, idegsebészet stb., amelyekben szintén releváns szerepet játszhat a telemedicina (BÁN A. 2014b).

A távgyógyászat jövőbeli használatát tekintve szintén igen megosztott a kép (16. ábra). Azoknak a szolgáltatóknak az egyharmada, akik jelenleg még nem foglalkoznak telemedicinális ellátással, vagy nem kerültek vele szorosabb kapcsolatba, bizonytalanok a távgyógyászat jövőbeni alkalmazását illetően. Ez feltehetően abból adódik, hogy számos akadályozó tényező ismert a finanszírozási hiányosságtól, a betegbiztonságon át a klinikai rutin változásáig (WHO 2010), ugyanakkor a hatékonysági kérdések sem hagyhatók 
figyelmen kívül. Az adaptálást több mint valószínüleg a rendelkezésre álló különböző források (pl. szakember, pénz, technika stb.) és lehetőségek fogják majd meghatározni.

A válaszadók további 30 százaléka egyértelmủ álláspontot foglal el, miszerint nem kívánja a távellátást integrálni a klasszikus ellátásba. Valószínüsíthetően nem látnak a távgyógyászatban jelentős potenciált és/vagy nincsenek meg a bevezetéséhez szükséges tényezők. Végül a szolgáltatók enyhe többsége, közel 40 százaléka az elkövetkező 1-2 éven belül alkalmazni akarja a telemedicinát, hiszen több esetben a szükséges rendszer már kiépítés alatt áll, és kísérletet tesznek a telemedicina jótékony hatásainak kiaknázására (pl. humánerőforrás hiány mérséklése, kapacitáskihasználtság növelése) (BÁN A. 2014b).

\section{6. ábra: A telemedicina jövőbeli alkalmazására vonatkozó tervek 123 válasz alapján}

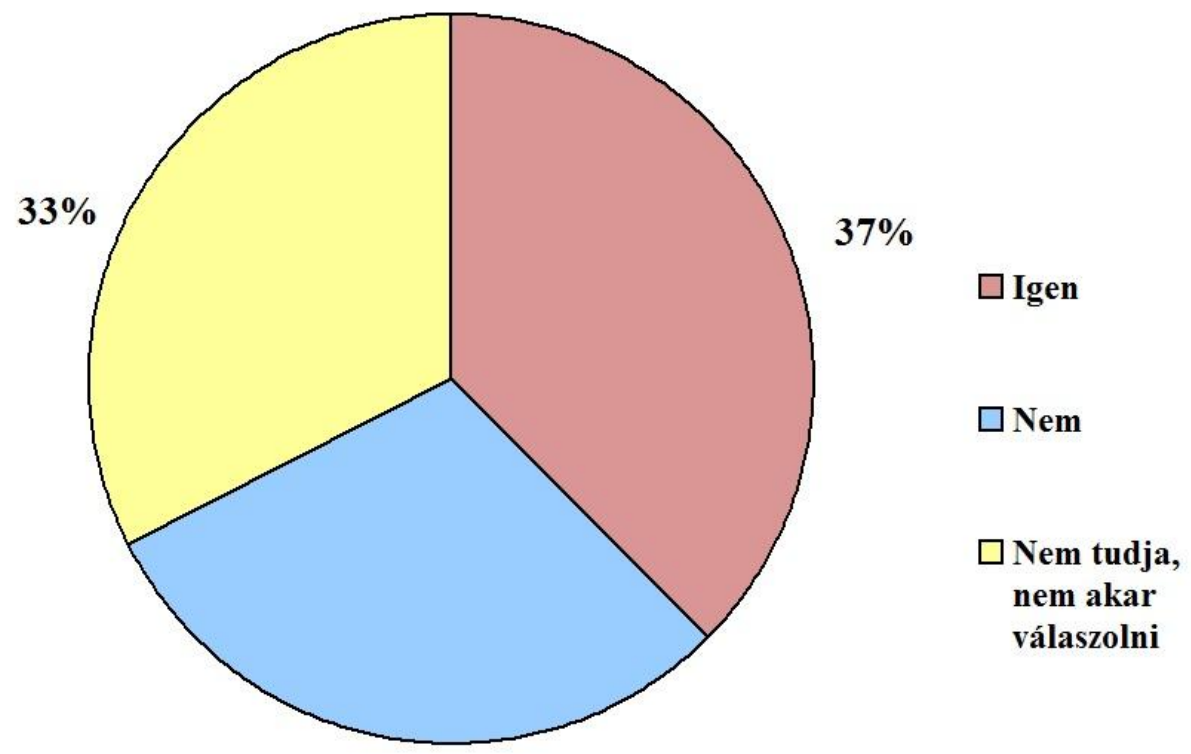

$30 \%$

\subsection{A telemedicinával kapcsolatos attitüdök és jövőbeli elképzelések az interjúpartnerek szemszögéből}

A kérdőíves adatfelvétel eredménye rávilágított a telemedicina néhány hazai, egészségföldrajzi vonatkozására, különös tekintettel a területi szempontokra. A távgyógyászat hatásainak megismeréséhez, a mechanizmus müködésének megértéséhez azonban félig strukturált interjúk (is) szükségesek. Ezek eredményeinek leírásánál az állításaimat minden esetben az interjúpartnerektől vett idézetekkel támasztom alá.

A távgyógyászat adaptálását, a telemedicinális szolgáltatások alkalmazását alapvetően determinálja, hogy az egészségügyi szakemberek milyen hozzáállással, attitüddel viseltetnek iránta. Milyen perspektívát látnak benne: mi az, amit tapasztalnak és mi az, amit elvárnának a távellátástól, továbbá miként képzelik el a telemedicina jövőjét Magyarországon. Ebben a tekintetben azt is érdemes figyelembe venni, hogy akik már használják, miként kerültek kapcsolatba a távgyógyászati lehetőségekkel.

Az interjúpartnerek a telemedicina hatásait és jövőbeli várható trendjeit több aspektusból közelítik meg, amelyek kapcsolatba hozhatók a távgyógyászat előnyeivel és hátrányaival, illetve az egészségügyi ellátórendszer problémáival. Az interjúalanyok közel négyötöde a telemedicinával kapcsolatos attitüdjeiröl kielégítően vagy jelentős mértékben számol be, de a jövőbeli elképzelésekröl is hasonló mértékben nyilatkoznak. 
Egyes interjúpartnerek különféle pályázatok útján kerültek kapcsolatba a telemedicinával, mint ellátási formával. Ebben a tekintetben pedig meghatározó a társadalmi tőke szerepe, hiszen a jó kollegiális kapcsolatban lévők ajánlják egymást a projektekbe, és kezdik - még ha kísérleti jelleggel is - alkalmazni a távgyógyászatot az ellátásban:

„Egyetemi pályázaton keresztül kerültem kapcsolatba vele, de korábbról is voltak kötödések..." (szülész-nőgyógyász, 36).

„,...elsöként egy olyan projekt kapcsán, ami a börgyógyászatban használatos, még pedig egy jó barátom, kollegám tett javaslatot..." (radiológus, 5).

Az információszerzés egy másik lényeges forrása az infokommunikációs technológiák, különösen az internet. Továbbá nem hagyhatók figyelmen kívül a különböző szakmai fórumok, találkozások, illetve az orvostudomány egyes innovációit bemutató szakirodalmi publikációk sem. Ebben a tekintetben sokszor előrelépést jelentenek a külföldi tanulmányutak és a kapcsolattartás. Az egyik háziorvos például a „...médiából részben, meg magából az internet különféle oldalairól... [hallott a telemedicináról] Olvastam olyan cikkeket, amiben már annak az eredményeit hozták..." (háziorvos, 55). Egy neurológus is a következöképp nyilatkozott: „, ... a tudományos közlemények, elöadások és konferenciák révén. Másodsorban a mindennapi élet is kínálta ezt a lehetöséget..." (neurológus, 23).

Azt is érdemes figyelembe venni, hogy az interjúpartnerek egy csoportja már hosszú évek (vagy akár évtized) óta alkalmazza a telemedicinát. Tehát bizonyos helyzetekben már bevett gyakorlatként jelenik meg a távgyógyászat és nem innovációként. Ez különösen igaz a teleradiológiára, hiszen a digitális technikára való váltással a távleletezésre is lehetőség nyílt: Az egyik radiológus szerint „...az elsök között jelent meg a radiológiában, és hát én radiológus vagyok, azt gondolom, hogy ... legalább már 8-10 éve mi ezt a mindennapi gyakorlatban rutinszerüen használjuk...” (radiológus, 35). Ezt erősítette meg egy idegsebész is, aki szerint „,...8-10 éve biztos, hogy ezt mi csináljuk. Tehát mikor ezt még más ki se találta, mi már ilyen VNC-rendszeren keresztül összekapcsoltuk a számitógépeinket és a képeket tudtuk transzportálni..." (idegsebész, 27).

Egyes interjúpartnerek - különösen a radiológusok - a humánerőforrás hiánnyal hozzák összefüggésbe a telemedicina alkalmazását az egészségügyben. A legtöbbjük ebben a tekintetben sikeresnek is tartja a távleletezést, mivel a szaktudás optimális eloszlását biztosítja távoli térségekben, ahol abszolút nincs orvos, vagy egyszerüen nem képesek megfizetni önálló, teljes állású radiológust az adott intézményben:

„....itt Magyarországon ... ennek a technikai feltételei meglettek, akkor egész egyszerüen az orvoshiány, az vezetett erre..." (radiológus, 6).

„... a világon, a legtöbb helyen, így nálunk is a szükség hivta életre, mert a kevés munkaeröt kell valahogy pótolni..." (radiológus, 17).

A radiológus interjúpartnerekhez hasonlóan a megkérdezett egészségügyi felsővezetők is a humánerőforrás hiány felől közelítik meg a telemedicinát, mint témakört. Egyfajta kényszer megoldásként jelenik meg a távgyógyászat, amivel az ellátásbeli egyenlőtlenséget lehet mérsékelni, különösen azokon a területeken, ahol a mindennapi ellátás anélkül nem biztosítható, mivel „...egyre növekvő orvoshiány van, és egy olyan gondolkodás indult el, hogy ha nincs elég orvos és nem tud minden beteg mellett ott lenni az orvos, akkor ilyen technikai eszközökkel próbáljuk ezt a hiányságot kiküszöbölni...” (egészségügyi felsővezetö, 22).

Több radiológus is hangsúlyozza, hogy nem csupán az orvoshiány, de a hatékonysági szempontok, illetve a kényelmi vonatkozások is fontos szerepet játszanak a teleradiológia alkalmazásában. Az otthoni leletezéssel pedig ez egyszerre teljesül, amit a legtöbben szintén pozitívumként értékelnek: 
„,...az ügyeleti rendszernél az idösebb radiológusok, akik messzebb laknak a kórháztól eleve szerettek volna nem folyamatosan ott lenni..." (radiológus, 21).

„...lehetöség nyilt, hogy otthonról is hozzáférésünk legyen a ... kórházi informatikai rendszerhez. És igy gyakran ... hát nyilván konzíliumot is adok otthonról, meg a CT-t ... otthonról szoktuk leletezni a kollégáimmal együtt..." (radiológus, 20).

Az interjúpartnerek szerint a hatékonysági szempontok több aspektusból is megragadhatók. A felesleges utazás kiváltása, csak úgy, mint a várakozás, illetve ezek időbeli és anyagi vonzatai a telemedicina minden részterületén kamatoztathatók, amit kedvezően értékelnek az interjúalanyok is:

„...a vártnál kisebb mértékben felhasznált, de mindenképpen egy lehetöség arra, hogy ne kelljen nekik fél napot itt ülni, lehetöség lenne arra, hogy az ember átnézné, ugye elöre mielött jönnek..." (belgyógyász, 49).

„,...nagyon sokszor teljesen felesleges az, hogy az ország valamelyik távoli pontjáról a beteg utazzon fel, mert önmagában a kép elég ahhoz, hogy döntést lehessen hozni, hogy milyen kezelésfajta szükséges..." (sebész, 14).

Az előzőeken felül egyes interjúpartnerek szintén pozitívan számolnak be arról is, hogy a telemedicinával lehet gyorsítani a betegutat és a páciens hamarabb juthat diagnózishoz, illetve minőségi ellátáshoz, amit egészség-nyereségként lehet értékelni (BÁN A. 2017a). Ehhez kapcsolódva a különböző krónikus megbetegedések folyamatos távoli monitorozása szintén jótékonyan befolyásolhatja a páciens egészségi állapotát, illetve az egészségügyhöz való viszonyát, ami visszahat az ellátórendszerben dolgozók attitüdjére is:

„,...kaptunk nagyon gyorsan egy korrekt diagnózist, terápiás javaslatot, megbeszéltük a beteggel, elinditottuk és nekem nagyon jó, pozitiv visszajelzések is érkeztek..." (háziorvos, $62)$.

„...TTEKG-t tudnánk betegeinknél használni, van nagyon sok olyan szívbetegség, amit nagy szerencse kell, hogy az ember elkapjon, hogy pont akkor van rendelöben, pont akkor csinálnak EKG-t..." (háziorvos, 58).

A korábbiakkal ellentétben vannak olyan tényezők is, amelyek kedvezőtlenül befolyásolhatják az interjúpartnerek telemedicinához való hozzáállását és viszonyát. Ezek közül egyik, talán legszembetünőbb a finanszírozás hiánya, ami különösen a pácienssel való távoli kapcsolattartást és az egészségügyi paraméterek monitorozását érinti. Egyesek szerint ez a fö oka annak, hogy nem müködik szervezetten a távgyógyászat, és amiért kevésbé preferálják, mivel jelenleg plusz feladatként interpretálják:

„,...semmiféle téritést nem kapunk, és ezért nem is nagyon fog átterjedni egészen addig, míg valaki korrektül nem finanszírozza..." (belgyógyász, 63).

„....nehezen kalkulálható, elsősorban azért, mert nincsen a finanszirozása jól, megfelelöen megalapozva..." (kardiológus, 24).

Ráadásul az interjúpartnerek egy meghatározó csoportja hiányolja a fizikai kapcsolatot mind a páciensekkel, mind pedig a kollégákkal. Egyesek meglehetősen személytelennek érzik a távgyógyászati ellátást, ez pedig alapvetően determinálja a telemedicinával kapcsolatos attitüdjüket. Akadnak olyan interjúpartnerek is, akik ezért kifejezetten ellenzik a távellátás alkalmazását:

„,...ez a koromból adódik, hiányzik az a fajta személyes kontaktus, ami egyébként minden betegnél, hogy úgy mondjam a fél gyógyulást jelenti...” (belgyógyász, 49).

„...nem tartom jónak, mert rendkívül nehézkes a betegek elözményének a megismerése, nehézkes a klinikusokkal való tárgyalás. Tehát én nem vagyok híve...” (radiológus, 3).

Az interjúpartnerek a telemedicina jövőjét is több aspektusból közelítik meg. A többségük alapvetően optimistán látja a távgyógyászat jövőbeni alakulását, és fejlődést prognosztizál, de 
vannak, akik szkeptikusak a jövendőt illetően, ami visszavezethető az egészségügy területi, strukturális és finanszírozási problémáira.

Egyes interjúalanyok szerint a humánerőforrás hiány egy kardinális kérdés és feltehetően a közeljövőben ez még fokozódhat is, „kikényszeríti” a telemedicina további fejlődését az egészségügyi ellátásban, ami különösen igaz lehet a teleradiológiára. Ez pedig a centralizáció irányába hat, mivel a távleletezés során a centrumokból elégítik ki a kisebb, távoli intézmények igényeit:

„... a teleradiológia úgy tünik, hogy előbb-utóbb majdhogy nem egyedülálló lesz szerintem ... igy próbálják meg a szakemberhiányt kiváltani és ez elvileg itt járható út...” (radiológus, 18). „,... a teleradiológia, az Magyarországon úgy lehet elképzelni, hogy vannak nagy központok ... akik felügyelik az adott szakma területi ellátását..." (radiológus, 7).

Az egészségügyi ellátórendszer területi és strukturális problémáinak tarthatatlansága miatt a távfelügyeleti szolgáltatásoknál is térnyerés várható egy informatikus szerint, aki „,..az öngondoskodásnak jósol jövöt, mert azt egész egyszerüen a világ ki fogja kényszeriteni ... nem lesz orvos, nem lesz pénz ... egyre inkább a racionális szempontok mindenféle politikai szemponttal szemben elötérbe fognak kerülni..." (informatikus, 26).

A távgyógyászat költséghatékonysági szempontjai is erősödhetnek a jövőben, mivel egyes interjúpartnerek szerint a telemedicinával racionalizálhatók lennének az egészségügyi kiadások. Ez pedig nem csupán a teleradiológiában kamatoztatható, hanem a krónikus betegségek távoli monitorozásában, és ezáltal a kezelésben is, így „,...azt gondolom, hogy bödületes mennyiségü pénzt lehetne megspórolni vele...” (dermatológus, 53). A telemedicinának köszönhetően „,...olyan információ bázishoz lehetne hozzáférni gyorsan, jól, amivel rengeteg pénzt, fáradtságot, mindent meg lehetne takaritani..." (radiológus, 35).

Egyes interjúpartnerek szerint a telemedicina jövőbeli sikere sok tényezőtől függ. Ebben pedig mindenekelőtt a finanszírozási háttér megteremtése kap meghatározó szerepet, de releváns a technikai, jogi és egyéb - elsősorban mentalitásbeli - akadályoknak a lebontása is. A távgyógyászat fejlődéséhez jelentős összegeket szükséges invesztálni ahhoz, hogy eredményeket lehessen elérni:

„...ha mind a szakmapolitikai, mind a financiális háttere ennek meglesz, én úgy érzem, ez nagyon gyorsan el tudna terjedni ..." (háziorvos, 51).

„....minden fronton, tehát jogi háttér, a finanszírozási háttér megteremtésével együtt ... a technikai részekkel, akkor nagyon sokat lehetne elöre lendíteni, általában a betegellátásban..." (neurológus, 23).

A telemedicina jövőjét illetően megjelenik az egységes informatikai platform terve is amiről egyik egészségügyi felsővezető számol be -, ami pozitív irányt mutat és ez némi elköteleződést is jelenthet az egészségpolitikában a távgyógyászat iránt. Ez azért is lenne fontos, mert lehetőséget teremtene az egyes progresszivitási szintek kapcsolódására és ezáltal a különböző betegadatok, illetve klinikai információk eléréséhez, ami jelenleg releváns problémákat jelent a telemedicina alkalmazásánál. Úgy véli, hogy a „...jelenlegi e-health programjainkban egy egységes informatikai rendszer mondjuk a kórházak, az alapellátás között és ... a páciens is bizonyos felhatalmazásokkal el tudja érni a saját leleteit ... erre már telepithetöek megfelelö internetes infrastruktúra esetén komolyabb telemedikális eszközrendszerek is..." (egészségügyi felsővezető, 19).

Az előzőek ellenére vannak, akik abszolút pesszimista képet prognosztizálnak a telemedicináról. Ennek okát pedig a távgyógyászat koncepcionális alapjának hiátusában látják. A jelenlegi telemedicinális ellátást lokális fellángolásként és egyedi pilot projektek rövidtávú sikereként identifikálják. Álláspontjuk szerin amíg a távellátást a mindennapi rutinba nem fogják integrálni, addig annak jövője kétséges: 
„,...minden, ami az egészségügyön belül zajlik, csak abszolút tüzoltásra törekednek ... 10 éves távlatban felépitett koncepciót senki nem tett le az asztalra. Márpedig ezt másképp nem lehet majd felépiteni helyesen ..." (belgyógyász, 63).

„....azt gondolom, hogy ez egyelöre nem mutat túl a kisérleti fázison ... csak néhány ember, néhány csoport, munkacsoport próbálkozása, vagy sikerélménye, vagy egyéni meggyözödése..." (patológus, 38).

Egyes interjúpartnerek szerint pedig a telemedicina a jövőben akár újra is termelheti az egyenlőtlenségeket, amennyiben nem integrálják az egészségügyi ellátórendszerbe, és nem szervezetten alkalmazzák. Ugyanis, ha nem lesz központilag finanszírozva - és különösen, ha emiatt a magánszektorban hódít teret - akkor bizonyos társadalmi rétegek marginalizálódhatnak a telemedicinális ellátásból.

Így megeshet, hogy lesznek, akik az egészségi állapotuk javítása érdekében a klasszikus ellátás mellett igénybe veszik a távgyógyászati szolgáltatásokat, ezáltal plusz egészségnyereséghez jutva, és lesznek, akik anyagi és egyéb lehetőségeik hiányában nem férnek hozzá. Az egészségegyenlötlenséget pedig csak tovább növelheti, ha pont azok szorulnak ki (pl. idősek, mélyszegénységben élők stb.), akiknek egészségi állapotuk miatt különösen szükségük lenne rá, hiszen „,...lesznek rétegek, akik maximálisan ki fogják használni ezt a lehetőséget, meg tudják finanszírozni, de ... széles rétegek számára támogatással nem nagyon lesz ez elérhető...” (háziorvos, 62). Ugyanezt támasztja alá egy másik háziorvos is: „...a magán ellátás felé orientálódik ... akkor a telemedicina a magánszektorban erösödik meg, és gyakorlatilag azt gondolom, hogy még inkább polarizálni fogja az ellátást..." (háziorvos, 44).

Az előzőeken túl a jövőt illetően azt is érdemes röviden megvizsgálni, hogy az interjúpartnerek hogyan vélekednek a távgyógyászat esetleges térnyeréséröl, méghozzá a face to face ellátás rovására. Vagyis el tudnak-e képzelni olyan víziót, amelyben a páciensek ellátása kizárólagosan telemedicinán alapul. Ez ugyanis egyfajta indikátora lehet az interjúalanyok távellátással kapcsolatos attitüdjének, a telemedicina preferálásának a mértékének.

$\mathrm{Az}$ interjúpartnerek egyöntetü álláspontja szerint a távgyógyászat soha nem fogja helyettesíteni, vagy kiváltani a személyes ellátást. A telemedicina csupán kiegészítheti az egészségügyi ellátást, aminek az ellenkezőjét nem tekintik reálisnak:

„,...nem nagyon tudom elképzelni, ez már ilyen futurisztikus ... az orvostudomány nem egy teljesen egzakt tudomány...” (radiológus, 35).

„,...olyan nem lesz soha, vagy legalábbis remélem. Nem minden információt lehet azért átküldözni. Milyen a betegnek a szaga, hogyan viselkedik, milyen a böre színe..." (belgyógyász, 52).

Egyesek szerint a távgyógyászat csupán redukálhatja az orvos-beteg találkozóknak a számát, mivel nem minden szituációban van szükség a páciens fizikai jelenlétére. Azonban noha a telemedicina elősegítheti a gyorsabb diagnózist, a gyógyításhoz sokszor a távoli kapcsolat nem elegendő:

„...biztosan nem fogja helyettesiteni az orvos-beteg találkozókat, legfeljebb csökkenti jelentösen azoknak a számát, illetve hatékonyabbá teszi az orvos-beteg találkozókat..." (belgyógyász, 63).

„,... a gyorsitásában segit, de hát akkor is kezelni is kell a beteget, nem csak...” (kardiológus, 29).

Összegzésként elmondható, hogy az interjúpartnerek telemedicinához való viszonyát számos tényező befolyásolhatja. Ezek között vannak, amelyek pozitív és vannak, amelyek negatív hatást gyakorolnak az ellátórendszerben dolgozók távgyógyászattal kapcsolatos attitüdjére. 
A telemedicinával kapcsolatos attitüdöt és szándékot, ami végül az adaptáláshoz vezet - a korábban felvázolt elméletek (innovációs elmélet, technológia elfogadása, tervezett cselekvés) szerint is - több tényező befolyásolja (SPIL, T.A.M. 2006). A távgyógyászat hatékonysága és használatának egyszerüsége, csakúgy, mint például az egészségügyi vezetők és döntéshozók pozitív állásfoglalása, illetve a rendelkezésre álló források alapvetően determinálják az érintettek telemedicinához való viszonyát.

Tekintettel arra, hogy a telemedicina az egészségügyi erőforrások hatékonyabb felhasználását teszi lehetővé, ez kedvezően hat az orvosok távgyógyászathoz való viszonyára. Ebbe beletartozik a szaktudás optimális eloszlása, a hatékonyabb munkaidő kihasználása, az utazás és várakozás redukálása. Ez pedig egy minőségi ellátást vetít előre a gyorsabb diagnózis, az ellátáshoz való hozzáférés tekintetében. Ugyanakkor vannak olyan tényezők is, amelyek kedvezőtlenül befolyásolják az érintettek attitüdjét. Ilyen például a finanszírozási és szervezeti problémák, továbbá az ellátás elszemélytelenedése.

Noha az interjúpartnerek alapvetően fejlődést prognosztizálnak a jövőben, ennek sikerét azonban a korábbi negatív tényezőktől teszik függővé. Az interjúpartnerek túlnyomó többsége évek óta alkalmazza a telemedicinát, annak kedvező hatásainak ellenére azonban továbbra is csupán komplementer szerepet tulajdonít.

A telemedicina jövőjét GIDDENS strukturációs elmélete szerint nagyban meghatározzák majd a szükséges források és egyes szabályok, társadalmi normák, amelyek egyszerre jelentkezhetnek korlátként és lehetőségként a sikeres fejlődés útjában (GIDDENS, A. 1984).

\subsection{A telemedicina térre és távolságra gyakorolt hatásai}

Mint korábban már jeleztem a telemedicina szigorúan vett egészségügyi és informatikai vonatkozásain túl földrajzi aspektusokkal is rendelkezik, ami mindenekelőtt hatékonysági kérdésekre vezethető vissza, melynek alapját az információs és kommunikációs technológiák adják.

Érdemes közelebbről is megvizsgálni, hogy miként jelenik meg a tér és a távolság szerepe

a távgyógyászatban, valamint hogyan vélekednek erről a telemedicinával foglalkozó egészségügyi szakemberek. Az interjúpartnerek több mint a fele kielégítően, vagy bőven nyilatkozik a fenti témáról, ami jelzésül szolgálhat annak fontosságára vonatkozóan.

$\mathrm{Az}$ interjúpartnerek szerint Magyarországon alapvetően nem a földrajzi távolság „legyőzése”, vagy eliminálása vezérli a telemedicina terjedését. Az ország területe jóval kisebb, mint az interjúalanyok által felsorolt példák, tehát ez valószínüleg kevésbé jelent mérvadó tényezőt a távgyógyászat alkalmazásánál:

„...van távolságcsökkentő szerepe, csak Magyarországon kívüli országokban még inkább kidomborodhat. Magyarország elég kis ország..." (belgyógyász, 40).

„Hát Magyarországon 'sémmilyen'. De Alaszkában igen, mert nagy távolságról beszélünk, Magyarországon kis távolságok vannak..." (neurológus, 30).

Véleményük szerint az ország kiterjedéséből fakadóan a fizikai távolságok nem jelentősek, ezért a telemedicina használatát sokkal inkább a humánerőforrás hiány okozta kényszerhelyzet generálta, amit különösen relevánsnak tartanak a radiológia tekintetében:

„,...Magyarország nem nagy ország, itt nincsenek távolságok. Magyarországon a radiológus hiányt kell, hogy orvosolja...” (radiológus, 4).

„,...nálunk jelen pillanatban sokkal inkább az egész teleradiológia az inkább a kevés orvosnak a pótlására vonatkozik..." (radiológus, 37).

$\mathrm{Az}$ orvoshiány okozta problémák mérséklése pedig lényegében az egészségügyi egyenlőtlenségek leküzdésére való törekvésként értékelhető. Főként a vidéki és periferikus térségekben, ahol a szakemberhiány hatványozottan jelentkezik és negatív hatásai még inkább 
kidomborodnak, ugyanis „,...nagyon nehéz bizonyos helyekre szakembereket szerzödtetni, és ezt ... kiválóan át lehet hidalni..." (radiológus, 11). Ez az oka annak, hogy a teleradiológia „...fóleg ott jelenthet elönyt, ahol nagyon perifériás területekre kell dolgozni... minél vidékebbre kerül az ember, annál kevesebb orvossal találkozik és nyilván ez valamilyen szinten próbálja kiváltani ezt a hiányt..." (radiológus, 18).

A speciális klinikai szakértelem centralizálódik a központi helyeken, de ez a szaktudás kamatoztatható azokban a térségekben is, amelyeket az orvoshiány különösen érzékenyen érint. A radiológiában ilyen jellegü centralizációs folyamatok zajlanak, ami a szaktudás optimális térbeli eloszlását teszi lehetővé, így „... a kisebb helyek, amik nem engedhetnének meg specialistákat, hozzájutnak a centrumokban dolgozó specialistáknak a szakvéleményéhez...” (radiológus, 17). A teleradiológiában „,...igy centrumok alakulhatnak ki ... amely igen nagy terület ellátását képes biztositani és itt a szakemberek koncentráltan, meg a szaktudás koncentráltan jelenhet meg...” (radiológus, 9).

Nem csupán a szakemberhiány térbeli egyenlőtlenségeinek mérséklésére való törekvés, hanem gazdaságossági szempontok is vezérlik a teleradiológia terjedését. Az időzónák kihasználásával például ki lehet váltani az ügyeleti időszakot, így olyan térségekből leleteznek, ahol éppen nappal van (és sok esetben egyébként is olcsóbb a kvalifikált munkaerö), aminek köszönhetően csökkenteni lehet a költségeket.

„,...az idözónák különbözösége miatt, ahol az éjszakai müszakra több pénzt kellene fizetni, ki lehet részben váltani azzal, hogy a más időzónában nappal leleteznek...” (radiológus, 16).

„....amikor fölkel a nap Ausztráliába, akkor Svédországba lemegy... és nem ügyeletet lát el, hanem nappali müszakot..." (radiológus, 5).

Az információs és kommunikációs technológiák lehetővé teszik tehát a fizikai távolság „megszünését” két végpont között. Ennek megfelelően az orvos és páciense között sem jelent problémát a kapcsolatteremtés a modern távközlési technológiákon keresztül:

„,... a földrajzi kötöttségét a betegnek jelentösen feloldotta ... számos olyan betegem van, aki a világ más részén él aktuálisan ... és akkor ez az egyetlen olyan lehetöség nyilván a kommunikációra..." (belgyógyász, 63).

„,...semmi különbség a kettő között, csak itt van $100 \mathrm{~km}$ madzag, itt meg összesen $100 \mathrm{~m}$ madzag. Ennyi ... informatikai távolság nincs...” (radiológus, 7).

Noha egyik interjúpartner szerint területi egyenlőtlenséggel a telemedicina esetében is számolni kell, ugyanis egyes periferikus térségekben az infokommunikációs technológiák sem mutatnak kedvező térbeli penetrációs mintázatot, így a távgyógyászat távolságcsökkentő hatása sem érzékelhető igazán:

„...a távoli, az az informatika szempontjából is távoli. Söt, valószínüleg távolabbi." (neurológus, 30).

A modern technikáknak azonban nem csupán a távolságra gyakorolt hatásai érzékelhetők az ellátásban, hanem a „helyfüggetlenség” is, mivel az interjúpartnerek szerint a telemedicina alkalmazása sokszor függetlenné válik a helytől. A távgyógyászat tehát „...elvileg létezhetne bárhol a Földgolyó pontján, és létezik olyan szinten is, hogy egyszerre akár többen is... (patológus, 38). Éppen ezért „,...azt mondják ... ahol már müködik, hogy bizonyos ... tevékenység nem távolsághoz kötött ... egy MR kép ... mindegy hogy hol leletezik egyébként, hogy ha az olyan minőségü, ami ezt a kockázatot kizárja..." (egészségügyi felsővezető, 19).

A technika fejlettsége lehetővé teszi, hogy az orvos akár a saját otthonából végezze a tevékenységét és tegyen eleget a kötelezettségeinek. Ez azért is releváns, mert a szakember tudása szükség esetén - időtől függetlenül - rendelkezésre áll, másrészt a kényelmi szempontokat is érdemes figyelembe venni:

„....Magyarországról is nagyon sokan dolgoznak külföldi cégeknek ... csak otthon a hálószobából ki se teszi a lábát..." (dermatológus, 32). 
„,...nem tud 365 napon, 24 órában lenni, ezért a mai technikai feltételekkel ... semmiféle nehézséget nem jelent otthonról ránézni...” (idegsebész, 25).

A telemedicina esetében a távolság mellett Magyarországon sokkal inkább az ellátás elérhetőségéhez szükséges idő válik releváns tényezővé. Az infokommunikációs technológiáknak köszönhetően a telemedicina lehetővé teszi az ellátás „gyorsítását”, ami a teleradiológiában például a leletezési idővel akceptálható:

„,...távol vagyok az ellátó helytöl, akkor az egy szempont, de hogy ha ... hosszú az idö, mert nagyon sokat kell várakozni, mert kicsi a kapacitása ... akkor megint csak egyfajta létjogosultságot nyer a telemedicina..." (dermatológus, 53).

„....halálfontos, hogy ez a technológia azonnal elérhetö legyen, és ugye ez robusztusan megbizhatóan müködjön. És ez így is van ... mi az akut eseteknél 30 perces megfordulási idöt szeretünk tartani...” (radiológus, 42).

Az ellátás elérhetőségének és hozzáférhetőségének javítása pedig hozzájárul a gyorsabb diagnózishoz, ami pozitív irányban befolyásolhatja az életkilátásokat. Továbbá a betegutak is lerövidülnek, és így a távgyógyászat optimális ellátást biztosít:

„....tehát időben észre tudnánk venni. Tehát nagyon sok látást meg lehetne, mondjuk ezzel az eggyel spórolni ..." (háziorvos, 55).

„,...köszönhetöen a telemedicinának gyakorlatilag a legrövidebb úton a legmegfelelöbb helyre került a páciens, tehát ez a legkézenfekvőbb célja..." (kardiológus, 29).

Ráadásul a telemedicina térbeli vonatkozásai költséghatékonyság szempontjából is értékelhetők. Ebben a tekintetben leginkább az utazás kiváltását és a munkaidő-kiesés redukálását érdemes figyelembe venni. Az interjúpartnerek szerint a páciens térbeli mozgásait fokozatosan felváltja az egészségügyi információ és adat nagy távolságokon át történő áramlása:

„,...akkor kisebb lesz az orvos-beteg találkozás, s valószínüleg nem kell neki eljönni, és esetleg ha dolgozó ember, nem kell neki munkából kimaradnia, de hozzá teszem, hogy ez mondjuk 100 beteg esetéböl $10 \%$ lesz...” (belgyógyász, 49).

„....az utazási költségek, a munkaidö kiesés, a kórházban bennfekvés nem szükséges, tehát kivált egy csomó olyan költséget..." (szülész-nőgyógyász, 1).

A fentieken túl a távgyógyászat nem csupán a térbeli- és időtávolságra (vagyis hogy mennyi idő alatt érhető el az adott ellátás) gyakorol hatást, hanem az interperszonális távolságra is. Az interjúpartnerek ennek pozitív és negatív aspektusairól egyaránt beszámolnak.

Akár az orvos-beteg kontaktus, akár pedig két egészségügyi szakember közötti kapcsolat erodálásához is hozzájárulhat a telemedicina, mivel a személyes találkozók száma redukálódik. Ugyanakkor ennek ellenkezője is bekövetkezhet, hiszen bizonyos szakterületeken megnövekedhet a távoli konzultációknak a gyakorisága, ami akár pozitív hatást is - szorosabb bizalmi viszonyt generálhat - gyakorolhat az orvos-beteg viszonyra. Egyrészt a távgyógyászati szolgáltatások „,...egy kicsit el is távolitják az embereket, ha a másik oldalát nézzük, igy kollegiálisan nem találkoznak egymással, nem tudnak úgy konzultálni, ahogy kellene, lehet kicsit személytelenit is a dolgon." (rezidens, 45). Másrészt viszont „...nincsen igazándiból távol a beteg, hanem hogy napi adatkapcsolatban van az orvosával, kvázi közelebb kerül hozzá..." (szülész-nőgyógyász, 1).

Összességében elmondható, hogy az interjúpartnerek alapvetően komplexen értelmezik a telemedicina teret és távolságot befolyásoló szerepét. Az információs és kommunikációs technológiák megjelenése és intenzív alkalmazása az egészségügyi ellátásban egyet jelent a távgyógyászattal. Azok az effektusok, amiket ezek a technológiák generálnak, jelentősen redukálják a fizikai távolság jelentőségét az ellátásban is, ami különösen meghatározó a nagykiterjedésü országokban és térségekben. 
Ugyanakkor Magyarországon kevésbé a földrajzi távolság leküzdése, mintsem inkább a humánerőforrás-hiány területi differenciáinak mérséklésére való törekvés támogatása, és ezáltal egy optimális munkaerő-eloszlás biztosítása a cél a távgyógyászattal. Ez pedig különösen a teleradiológia létjogosultságát adja. Ebben a tekintetben az empirikus eredmények a nemzetközi szakirodalommal összhangban a szakértelem centralizációjáról és az ellátás decentralizációjáról tanúskodnak (AAS, I.H.M. 2007, 2013, CUTCHIN, M.P. 2002, STRÖMGREN, M. 2003).

Azáltal, pedig hogy nem a betegek utaznak, hanem csak az információk áramlanak a térben, így jelentős költséghatékonyságot lehet elérni, kiváltva a páciensek és az egészségügyi szakemberek utazását, illetve utaztatását. Ami pedig kiváltképpen releváns lehet a beteg szempontjából, az nem más, mint az ellátás elérhetőségének és hozzáférhetőségének javulása, ami több esetben az optimális betegutat is jelentheti.

Így jelentős egészség-nyereséget lehet elkönyvelni azáltal, hogy időben történik a betegség, vagy kóros állapot diagnosztizálása és szükség esetén kezelése. Erre pedig lehetőséget ad az egészségügyi alapfunkciók távoli monitorozása is, ami ugyan csökkentheti a személyes találkozók számát, nem feltétlen jelenti az interperszonális távolság növekedését, ellentétben azokon a telemedicinális területeken, ahol lényegében semmilyen kapcsolat nincs orvos és beteg között, vagy egészen jelentéktelen (lásd teleradiológia).

\subsection{A telemedicina hatékonysági kérdései}

A telemedicina hatékonyságáról a hazai és nemzetközi szakirodalom egyaránt beszámol, ami egyébként visszavezethető az infokommunikációs technológiák jótékony, egyenlőtlenséget redukáló szerepére (FICZERE A. 2010a, MATUSITZ, J. - BREEN, G.M. 2007).

Ezért is érdemes megvizsgálni, hogy mely szakterületeken alkalmazható leginkább a telemedicina, képes-e minőségi változást hozni az ellátásban, továbbá miként hat a szakorvosi és az alapellátásra. A hatékonyság egyfajta indikátoraként lehet interpretálni azt is, hogy vajon az orvosok leterheltségét mérsékli-e, vagy éppen ellenkezőleg, növeli azt.

Maguk az interjúpartnerek is komplexen értelmezik a telemedicina hatékonyságát, ezért egyesek inkább az előbbi, míg mások az utóbbi mellett foglalnak állást. Ugyanakkor többen hangsúlyozzák, hogy a kérdés megítélésében nehéz tapasztalat hiányában döntést hozni, hiszen a távgyógyászat még gyerekcipőben jár, ezért annak hatásait csak évekkel az adaptálást követően célszerü mérni és kvantifikálni.

Ráadásul az sem hagyható figyelmen kívül, hogy a távellátás nem a mindennapi rutinban alkalmazott, hanem csak szórtan, így ez szintén akadálya lehet a hatékonyság identifikálásának. Mindenesetre a kérdés fontosságát igazolja, hogy az interjúalanyok kétharmada jelentős mértékben számol be álláspontjáról.

Egyesek szerint a telemedicinális szolgáltatásokat az orvostudomány minden területén lehet alkalmazni, ugyanakkor nem az adott szakterület teljes spektrumában, hanem jól

beazonosítható szubspecifikumban. Így a távgyógyászat hatékonysága kamatoztatható a klasszikus ellátás mellett:

„,...nincs olyan területe az orvostudománynak, ahol ne lehetne hasznositani a távgyógyászatot, költséghatékony módon...” (szülész-nőgyógyász, 1).

„....minden szakterületen biztosan meg lehet találni, de ezek szük területek. ” (neurológus, 30).

A képi alapon történő diagnózis felállításához megfelelő eszköz a telemedicina, így különösen a radiológiában lehet meghatározó szerepe. Ezen belül a RTG, CT, MR képek távleletezésénél kiválóan alkalmazható: 
...a radiológiának majdnem minden területén alkalmazható. Ugye a CT, MR-ben széles körben alkalmazzák is, ez nem is kérdés. A röntgenfelvételeket nyilvánvalóan lehet távolról... (radiológus, 11).

Noha a radiológiában általában használható a telemedicina, mégis vannak olyan részterületek, amelyekben nem célszerü. Számos interjúpartner hangsúlyozza, hogy az ultrahangos vizsgálatnál szükséges az orvos jelenléte és bár történnek próbálkozások ennek kiváltására (lásd szonográfus), egyesek mégsem tekintik ezt üdvözítőnek, mivel „,...ahogy szokták mondani, mindenki a saját kezével lát jól...” (radiológus, 9). Ennek megfelelően „...vvannak bizonyos vizsgálatformák a radiológiában, amiket nem lehet távolról végezni, ilyen az ultrahang, amikor az orvosnak ott kell fogni..." (radiológus, 17).

Az ultrahangon kívül ide tartozik a sürgősségi ellátás is, melynek oka abban keresendő, hogy ilyen esetekben életek múlhatnak a biztonságosan és gyorsan elérhető ellátáson (technikai problémák pedig bármikor adódhatnak):

„...hagyományos röntgenben, az esetek 80 \%-ában lehet alkalmazni. Ahol nem lehet alkalmazni ... ahol ügyeleti ellátás van ... ott legyen radiológus. Ahol sürgősségi ellátás van, legyen radiológus..." (radiológus, 7).

A képi alapon történő diagnózisokon túl a telemedicina alkalmazható a különböző krónikus betegségek távoli monitorozásánál is. Ez pedig lehetőséget ad a betegség további súlyosbodásának csökkentésére, az esetleges szövődmények elkerülésére:

„...jó esély van a használatára, az a cukorbeteg gondozás, a magas vérnyomás gondozás, szivelégtelenség, krónikus obstruktív tüdőbetegség, és talán még a veseelégtelenség is ... mindenhol lehet haszna, minden krónikus betegségben ..." (kardiológus, 24).

Ugyanakkor a távgyógyászatot mindenekelőtt a diagnózis megállapításánál lehet használni, a gyógyításhoz, a betegség kezeléséhez általában szükséges a páciens fizikai megjelenése. Ez az oka annak is, hogy az interjúpartnerek a legtöbb esetben a face to face ellátás mellett csak komplementer szerepet tulajdonítanak a telemedicinának:

„,... rendben van, hogy látok egy EKG-t ... de telemedicinával nem tudunk kezelni vele semmit. Ahhoz kell egy orvos-beteg kapcsolat, hogy lehessen gyógyitani is. Nyilván ez arra hivatott, hogy ezt a diagnosztikus részt gyorsitsa fel..." (kardiológus, 29).

„....amikor betegtalálkozást nem érintő diagnózis felállítás van, ott teljesen jól müködhet a dolog ... a közvetlen gyógyítás telemedicinával nem látok sem távolságcsökkentő hatását ... ott a beteg is akkor nyugszik meg, amikor az orvos a közelben van..." (informatikus, 8).

Az előzőekhez köthetően érdemes azt is megvizsgálni, hogy miként hat a távgyógyászat az ellátás minőségére, milyen léptékü változást generálhat a klasszikus ellátásban. Ebben a tekintetben is különböző álláspontok feszülnek egymásnak. Egyrészt vannak, akik szerint a telemedicinális ellátás során nem romlik az ellátás minősége a beteg fizikai jelenlétén alapuló ellátáshoz képest. E szemlélet különösen a képi alapon történő diagnózis megállapításánál jelenik meg:

„Én azt gondolom, hogy van az eseteknek egy része, amiben nincsen, ahol tényleg tudok ugyanolyan korrekt diagnózist és korrekt terápiát is adni..." (dermatológus, 53).

„,...szük ... spektrum, amikor jobb, hogyha helyben van a leletezés. Egyébként ... egy CT, MR esetén, az hogy hol leletezik ... majdnem hogy mellékes..." (radiológus, 20).

Az interjúpartnerek egy másik csoportja szerint a távgyógyászattal egy jelentős minőségi javulás is hozható az ellátásban. Ez részben a képalkotó diagnosztikában valósul meg, aminek oka a speciális klinikai szakértelem optimális eloszlásában rejlik.

Az egészségügyi centrumokban koncentrálódó implicit tudás, amit a felhalmozódó beteganyag generál, kisebb, alacsonyabb progresszivitású intézményekben is elérhetővé válik. Ez pedig jobb minőségű ellátást is hozhat a radiológiában, mintha egy elszigetelten dolgozó szakorvos látná el az adott esetet, ugyanis ,,...egy kisebb helyen soha nem lehet, akármennyire 
is szorgalmas egy ... orvos, soha nem lehet akkora tapasztalatot összegyüjteni, mint egy központi helyen...” (radiológus, 13). Az ellátás minőségét javíthatja, ha „,...egy expert van a másik végén, aki naponta 30-at lát, az más véleményt tud mondani, mint aki kezdö korában egyet lát hetente..." (radiológus, 5).

Ez a minőségi változás azonban a távfelügyeletnél is jelentkezik és a pontosabb, megbízhatóbb diagnózist szolgálja. Az egyes egészségügyi alapfunkciók távoli monitorozása egyrészt a kóros állapotok gyorsabb kiszürését teszi lehetővé, másrészt támogatja az orvosi döntéshozást. Bizonyos helyzetekben tehát akár jobb ellátást is hozhat a távgyógyászat, mint önmagában a klasszikus ellátás, mivel „...a hagyományos ellátásnál 1000 gyerekböl elvesztünk 4-et, 5-öt méhen belül ... most már 1400 szülés után vagyunk és még egyet sem vesztettünk el..." (szülész-nőgyógyász, 1).

A döntéshozás támogatása a technikai lehetőségekből adódik, melynek köszönhetően számos plusz adat áll rendelkezésre a diagnózis megállapításához, esetleg a terápiás javaslathoz, ami segítheti az orvos munkáját és növelheti a minőségi ellátást:

„...egyre több adatra fog alapozódni minden döntés ... az egészségügyi rendszerekben jelenleg nagyon sok szubjektiv döntés van ... objektíven jobb döntéseket lehet hozni, és az egyre inkább elérhetôvé válik..." (kardiológus, 24).

„....maga az orvostudomány is nagyot tud azzal lépni, hogy ha nagyon nagy mennyiségü adatot kaphat akár betegségekröl..." (informatikus, 28).

A fentiekkel ellentétben megjelenik egy olyan álláspont is, ami szerint a telemedicina minőségileg nem garantál olyan ellátást, mint ha klasszikus úton történne a páciens vizsgálata: „...ez pontosan olyan, a telemedicina az egy kényszer megoldás, szögezzük le ...” (neurológus, 23).

„....mindenképpen érzékelek, igen. Nem beszélve arról, hogy a hagyományos ellátásban ... van egy megbeszélésünk ... elöfordult olyan eset, amellyel a kollégáim nem tudnak megbirkózni, vagy kételyeik vannak, azt itt reggelente meg tudjuk beszélni..." (radiológus, 3).

A telemedicina ellátásra gyakorolt hatásainak értékelésénél a korábbi álláspontoktól függetlenül az interjúpartnerek egy meghatározó csoportja hangsúlyozza, hogy a klasszikus és a telemedicinális ellátás nem összehasonlítható kategória. Noha a távgyógyászat bizonyos helyzetekben szolgálhat alternatívaként, de alapvetően komplementer szerepet kap az ellátásban.

A telemedicina a face to face ellátás prioritását nem kérdőjelezi meg, hiszen a páciens fizikai jelenléte általában több információval szolgál, hiszen ilyen esetben a szakember nem csupán a látására, vagy a hallására hagyatkozik a diagnózis megállapításánál. Tehát nem csupán egy adatot, információt, vagy a beteg egy testrészét látja, hanem a „teljes” pácienst:

„....az egyik nem helyettesíti a másikat ... ez nem úgy müködik, hogy ha telemedicinát tudunk alkalmazni, akkor onnantól kezdve én ülök egy monitor elött...” (háziorvos, 44).

„...érzékszerveink száma több, ha személyesen látjuk el. Tapintok, látok, szagolok, stb. Esetleg a szemébe nézek, és bizonyos információkat összeszedek. Ettöl függetlenül olyat is szoktunk csinálni, hogy..." (háziorvos, 34).

Mindenesetre a telemedicina hatékonysága az alap- és szakellátásban egyaránt kamatoztatható és több aspektusból is megragadható. Az interjúpartnerek egy része külön kiemeli a távgyógyászat költséghatékonyságát. Ez részben az utazási költségek redukálódásából fakad, részben a munkából való kimaradás gyakoriságának csökkentéséből, ami egyben produktív időt is jelent, csak úgy, mint a várakozási idő mérséklése:

„....itt most a beteg éri el könnyebben ... a beteg takarít meg idöt, neki nem kell szabit kivenni, neki nem kell költenie az utazásra..." (belgyógyász, 46).

„... a megterhelés, a pszichés és ... testi problémák fokozódása lecsökkenthetö, nem kell várakozni, minden sokkal olcsóbb, nem kell utazni..." (háziorvos, 41). 
A távgyógyászat hatékonysága nem csupán financiális szempontból vizsgálható, hanem elérhető egészség-nyereségből is. Ez elsősorban a gyors diagnózisra, a kóros állapot mielőbbi felismerésére, és a prevencióra vezethető vissza, ami kedvezően hat a páciens egészségi állapotára. Ráadásul növeli a beteg biztonságérzetét és az orvossal való együttmüködését, compliance-t, ami szintén pozitív egészségügyi hatásként értékelhető. A betegek „....hamarabb diagnózishoz jutnak, hamarabb felismerik azokat az állapotokat, amelyek veszélyt jelenthetnek ... tehát mindenképpen pozitívum, hogy ha van ilyen lehetöség..." (háziorvos, 51). A telemedicina „,... a selfcare rendszerekben lehet nagyon hasznos ... egy krónikus betegség gondozásában, illetve a magas kockázatú betegeknél a szövödmény megelözésénél, a súlyosabb állapot megelözésénél...” (egészségügyi felsővezető, 19).

$\mathrm{Az}$ interjúpartnerek egy csoportja szerint amennyiben az alapellátásban a napi rutinban alkalmaznák a telemedicinát, úgy további egészség-nyereséget is el lehetne könyvelni. Ennek egyik pozitív externáliája az lenne, hogy szakorvosi szintü ellátást kaphatnának a páciensek az alapellátás keretében, így ez jelentős mértékben redukálná a betegutakat és nagyobb eséllyel töltenék be a családorvosok is a „kapuőr” szerepüket:

„,...ha jól müködne, akkor iszonyatos mértékben befolyásolhatná ... akkor gyakorlatilag bármit el tudna végezni a családorvos egy megfelelö távgyógyászati háttérrel..." (szülésznögyógyász, 1).

„,...ezzel tudja növelni az ö saját kompetencia szintjét ... magasabb szintü szolgáltatást tud végezni, helyben a betegnek..." (radiológus, 5).

Az előzőeken felül a hatékonyság indikátoraként interpretálható a távgyógyászat szakorvosi leterheltségre gyakorolt hatása is. Az interjúpartnerek több aspektusból közelítik meg a témát. Az egyes álláspontok ütköznek egymással, amelyek bizonyos helyzetekben feltehetően megállják a helyüket.

$\mathrm{Az}$ interjúalanyok egy csoportja szerint a telemedicina nem csökkenti, hanem tovább növeli az orvosok munkaterhelését. Ez részben annak tudható be, hogy a távoli munkavégzésnek köszönhetően egyszerre több intézménynek dolgoznak be (lásd teleradiológia), ami növeli ugyan a bevételüket, de jelentősen redukálja a szabadidejüket. Ez pedig káros is lehet, hiszen csökken a munkaerő reprodukciós ideje.

Ráadásul tekintettel az egyes szakterületekre, ahol a telemedicina a klinikai rutinba még nem ágyazódott be, az egészségügyi szakemberek általában plusz feladatként élik meg a távgyógyászati lehetőségeket, mivel ezek a szolgáltatások alapvetően nem finanszírozottak. Az ellátás minőségének növelése érdekében végzik egyes orvosok, de sokszor munkaidőn felül, valamint anyagi honorárium nélkül (lásd távfelügyelet):

„...szerintem növeli ... mindenki az összes idejébe próbál dolgozni ahhoz, hogy meg tudjon élni..." (radiológus, 13).

„,...növelheti szerintem, tehát mindenkinek megvan a napi dolga, ha még ezenfelül speciális tanácsokat, konzultációkat ad, minél nagyobb területen, minél nagyobb számban, az a feladatait fogja növelni. Sokan pont emiatt ódzkodnak ... a telemedicinától...” (kardiológus, 29).

Ugyanakkor egyes interjúpartnerek azt is hangoztatják, hogy, noha a telemedicina növelheti a munkával töltött idő mennyiségét, de a döntés az orvos kezében van: mi az, amit teljesít és mi az, amit nem. Ezt természetesen számos tényező befolyásolhatja, többek között az attitűd, a hivatástudat, a páciensek felé mutatott empátia, a szabadidő mennyisége, a magánélet, anyagi jólét és egy sereg más tényező. A leterheltség pedig megfelelő keretek között menedzselhető, hogy a munka nem menjen az ellátásban dolgozók szabadidejének rovására: 
„,...nem egy kötelezett munkavállalás, hanem önkéntes munkavállalás, mindenki annyit vállal pluszba, amennyit a saját életébe be tud illeszteni. Ezért mondtam azt, hogy optimálisabb munkavállalást jelent..." (radiológus, 17).

„....van esély, de ez relativan jól szabályozható, tehát be lehet ebbe szürőket, fékeket épiteni. Tehát a telemedicina nem azt jelenti, hogy egy adott szakember éjjel-nappal rendelkezésre áll, hanem akár időbe lehet korlátozni a hét bizonyos napjain..." (szülész-nögyógyász, 36).

$\mathrm{Az}$ elözőeken felül megjelenik egy olyan álláspont is, miszerint összképet tekintve alapvetően nem befolyásolja a távgyógyászat az orvosok leterheltségét. Noha a telemedicina a szaktudás optimális eloszlását teszi lehetővé, az ellátandó esetek számára nem gyakorol hatást. Amennyiben egyes területeken mérsékli is a szakorvosi munkaidőt, más helyen ezzel ellenkező hatást kiváltva növeli, hiszen az ellátást biztosítani kell. Ennek megfelelöen „,...X mennyiségü beteg vizsgálatához Y mennyiségü szakorvosi idö szükségeltetik... az idö az kell rá, legfeljebb tovább passzoltam máshova, más szakorvosnak, de globálisan a szakorvosi idö az ugyanannyi...” (idegsebész, 25). Éppen ezért a telemedicina „...szerintem terhet nem fog levenni ... igazából, mert a leterheltség alapvetöen attól függ, hogy összbetegszám/orvos. Ez nagyon egyszerü egyenlet, én úgy gondolom..." (dermatológus, 53).

E szempontokkal szemben azonban az interjúpartnerek egy csoportja szerint a telemedicina képes csökkenteni a szakorvosok leterheltségét. A teleradiológiában ennek okát a munkaidő hatékonyabb kihasználásában látják. Így azonos idő alatt jóval több esetet képesek ellátni, mint távleletezés nélkül, ami feltétlen szükséges is az ellátás biztosításához:

„....nem, csak a munkaidejüket használják ki jobban. Legalábbis a radiológiában..." (radiológus, 7).

„...nem olyan nagy a növekedés, mintha nem lenne teleradiológia, tehát valamilyen módon evvel tudjuk ... a terhelést csökkenteni, de eleve többre van szükség...” (radiológus, 37).

Egyes interjúpartnerek szerint szintén a leterheltség csökkenésének irányába hat az is, hogy az orvos nem találkozik fizikailag a pácienssel, csak a beteginformációval. Lényegében virtuális vizitekről lehet beszélni, amelyek összehasonlítva a face to face vizsgálattal, időben jóval hatékonyabbak annál. Ezekben az esetekben ugyanis az egészségügyi szakember idejét csak az objektív adatok és információk kötik le és egyéb tevékenységek nem redukálják, noha ez kétség kívül jóval személytelenebb. A telemedicinális ellátás az orvost „,... kevésbé terheli, hiszen ... csak információk érkeznek adott betegröl, adatok érkeznek, amit ... elemezni kell és konzílium szintjén visszajuttatni...” (radiológus, 5). Ennek köszönhetően „,...meg tud nézni 15-20 e-mailt 15-20 perc alatt, míg 15-20 beteg találkozás, az legalább felszorozva 15 perccel, tehát jóval idő spórolóbb, akár technikai, akár emberi erőforrást spóroló..." (belgyógyász, 40).

Az előzőekben felsorakoztatott meglátások és tapasztalatok azt mutatják a telemedicina hatékonysági kérdéseihez alapvetően nem fér kétség. Ez lényegében az infokommunikációs technológiák hatásaira vezethető vissza. Az idö- és költséghatékonyságon felül azonban a gyorsabb diagnózis, kezelés és megelőzés által az egészségi állapotra is pozitív hatást fejt ki.

Az orvostudomány számos szakterületén alkalmazható, különösen a képi alapon történő diagnózis felállításánál és a távoli egészségügyi paraméterek monitorozásánál. Bizonyos helyzetekben biztosíthat olyan ellátást (lásd távleletezés), mint a klasszikus orvos-beteg találkozásnál megszokott, de alapvetően a telemedicina nem a face to face ellátás kiváltására, hanem annak kiegészítésére szolgál. Komplementer szerepben, vagyis a klasszikus értelemben vett ellátással együtt feltehetően jobb minőségü ellátás is biztosítható, mint nélküle.

A telemedicina hatékonyságát azonban a cselekvőhálózat elmélet figyelembevételével érdemes értékelni. Nem csupán egy-egy tényezőt kell vizsgálni, hanem a hálózat emberi és materiális elemeit együttesen. Ebbe beletartoznak az egészségügyi szakemberek, páciensek, 
technikusok éppúgy, mint a maga a szükséges infrastrukturális tényezök (pl. internet, informatikai rendszer stb.) egyszóval a szükséges hardver és szoftver egyaránt. Optimális hatékonyságot és így a rendszer hosszútávú sikeres müködését csak a hálózat fenti heterogén elemeinek a harmonikus együttmüködése teremtheti meg (JóHANNESSON, G.T. BAERENHOLDT, J.O. 2009).

Tekintettel arra, hogy a telemedicina egyes szolgáltatásait a mindennapi ellátásban rendszer szinten nem alkalmazzák, és nem finanszírozzák, így valószínüsíthetően jelenleg még plusz feladatot jelent azoknak, akik így is használják. Ráadásul az infokommunikációs technológiák, amelyek támogatják az egészségügyi szakemberek - különösen az expertek kedvezőbb elérhetőségét, egyúttal hozzájárulhatnak ahhoz is, hogy a leterheltségük növekedjen. Ugyanakkor az sem hagyható figyelmen kívül, hogy a hatékonyabb időfelhasználásnak köszönhetően az egy esetre jutó ellátási idő jóval kevesebb, így e szempontból akár csökkenhet is a szakorvosok leterheltsége.

\subsection{A telemedicina alkalmazását és terjedését gátló, illetve adaptálását segítő tényezők}

A telemedicina alkalmazását és diffúzióját az egészségügyi ellátórendszerben számos tényező akadályozza. Ezek összegyüjtése és területi mintázatának bemutatása mindenekelőtt az Egészségügyi Világszervezethez köthető (WHO 2010). Az egyes interjúpartnerek az interjúk során e barrierek többségéröl szintén beszámolnak.

Érdemes tehát figyelembe venni, hogy melyek azok a faktorok, amelyek az ellátórendszerben dolgozó orvosok praxisában is akadályként jelennek meg, csakúgy, mint azok, amiket a telemedicinával érintett egyéb szakemberek ( $\mathrm{pl}$. informatikusok) is a mindennapok során megélnek, így a távgyógyászat alkalmazását megnehezítik. Ebben a tekintetben az interjúpartnerek több mint kétharmada kielégítö, vagy tekintélyes mennyiségben fejti ki reflexióját, ami egyfajta igazolását adja a kérdés relevanciájának.

Az egyik, talán leggyakrabban előkerülő barrier a pénz, a költség, a megtérülés és a finanszírozás csoportjába sorolható. Ezek közül is a leginkább szembetűnő, hogy a telemedicinális ellátás finanszírozása - mindenekelőtt a távfelügyelet - alapvetően a mai napig nem megoldott a magyar egészségügyi ellátórendszerben (bizonyos kivételtöl eltekintve) (FICZERE A. 2010a). Ez pedig determinálja az egészségügyi szakemberek attitüdjét a távgyógyászati alkalmazások használatával kapcsolatosan. A telemedicinális ellátás során problémaként jelentkezik, hogy „....az OEP nem finanszírozza a betegekkel való e-mailes kapcsolattartást, nem lehet elszámolni, mint betegvizit..." (belgyógyász, 40). Ebből adódóan „....mivel ez nincsen finanszírozva, ezért nem, nem fektetnek rá idöt az intézmények, szolgáltatók..." (kardiológus, 24).

Noha a telemedicina egyik elönye a költséghatékonyság, ezt egyes interjúalanyok megkérdőjelezik bizonyos ellátási területeken. Ennek oka mindenekelőtt a szükséges infrastrukturális beruházási és amortizációs költségekben keresendő, továbbá az sem hagyható figyelmen kívül, hogy a klasszikus ellátás standardizált költségével sokszor nehéz versenyezni:

„....az OEP, az állami ellátásban mintegy 700 ponttal dotál. Nagyon nehéz olyan ellátó számítástechnikai rendszert kiépíteni, amivel gyakorlatilag ... alá lehet menni költségekben...” (dermatológus, 53).

„....tulajdonképpen ilyen szempontból, hogy nem utazik a radiológus, nem pocsékolja idejét, nincs utazási költség, ez még akár rentábilisabb is lehetne. De valószínüleg nem lesz, mert fönt kell tartani hozzá egy müszaki hátteret, azt karban kell tartani...” (radiológus, 16).

A fentiekkel szemben azonban van, aki az ellenkezőjét állítva a költséghatékonyságot továbbra is relevánsnak tekinti és azt a rendeltetésszerü használatra vezeti vissza: 
„, ...vannak ilyen pletykák, hogy a teleradiológia az drága. Lehet drága a teleradiológia, hogy ha rosszul használják..." (radiológus, 42).

További problémát okoz a finanszírozás terhének viselése, ugyanis a hatékonyság ellenére - amennyiben a felmerülő költségeket maguknak a pácienseknek kell direkt megtéríteni - az a projekt gyors elhalásához vezethet. Tehát valószínüsíthetően a betegek általában nem preferálják a fizetős ellátási formákat, ami feltehetően abból fakad, hogy a fizikai jelenléten alapuló állami ellátást nem közvetlen a páciens téríti meg a szolgáltató irányába, így „....konkrétan, amelyiknél fizetös volt ... ezt nem tudom megfizettetni semmiért...” (háziorvos, $34)$.

A financiális kérdések mellett a technológiai tényezők is egy meghatározó csoportját képezik a távgyógyászat esetében felmerülő akadályoknak. Itt különösen releváns szerepet kap az internet paraméterei és általában az információs technológiák, amelyek fajlagos költségei noha jelentősen redukálódnak, még mindig egy jelentős tételt képeznek. Ugyanakkor e technikai feltételek minősége és megfelelö hozzáférhetősége alapvetően determinálja a telemedicinális ellátás minőségét:

„...ezek a számitógép monitorok felbontásakor is több technikai tényezö miatt nem tudják felvenni a versenyt ... egy leletezö monitorral ... a másik dolog az internet ... egy hasi CT vizsgálat mondjuk ezer valahány száz képböl áll. Ahhoz azért adatforgalom kell..." (radiológus, 13).

„...nagy teljesitményü számitógép kell hozzá, jelentős sebességet biztositó internetkapcsolattal és az korlátlan legyen, bármikor elérhetö, és ne akadozzon..." (belgyógyász, 63).

A technikai akadályok egy további sajátos eleme az egységes informatikai rendszer hiátusa. Ebben a tekintetben érdekellentéteket vél felfedni egyik informatikus válaszadó, ugyanis álláspontja szerint ehhez a fejlesztők nem járulnak hozzá, hiszen az egyet jelentene a rendszer feletti diszponálás lemondásával. Éppen ezért „...az információs rendszernek az átjárhatóságát a gyártó cégnek nem érdeke biztositani ... most hát nyilván a telemedicinának az egyik alapfeltétele az információs rendszer átjárhatósága...” (informatikus, 26).

A fentiekhez kapcsolódva szintén releváns a technika megfelelő alkalmazásához szükséges ismeretek és készségek elsajátítása, aminek hiánya szintén barrierként jelentkezik a távgyógyászatnál.

Ebben a tekintetben érzékelhető egyfajta generációs szakadék az orvostársadalmon belül is, hiszen általában az idősebb orvosok kevésbé preferálják a különféle információs és kommunikációs technológiák alkalmazását és rendszerint kevésbé éreznek affinitást azok használatához nélkülözhetetlen kvalitások megszerzésére:

„...nem könnyen várható el idösebb kollégáktól, hogy ennyire új technológiát abszolút uralni tudjanak, vagy megtanulják azokat az ismereteket, amelyek ehhez szükségesek..." (idegsebész, 25).

„,...nem mindegyik orvos alkalmas arra, hogy otthon egyedül hagyva, egy viszonylag bonyolult rendszert kezeljen. És ebböl következik ... hogy ehhez megfelelö technikai felkészültség kell...” (radiológus, 37).

A generációs szakadék pedig tovább mélyül, mivel egyre inkább érezhető nem csak az egészségügyi szakemberek, hanem a páciensek oldaláról is. A fiatal betegek többségében nagyobb hajlandóságot és késztetést éreznek a modern technikák bevonására az ellátásuk és egészségi állapotuk menedzselésére:

„,... azt gondolom, hogy ahogy csúszik a régi generáció, és ahogy az új generáció fog elötérbe kerülni, ezek egyre inkább alkalmazásra kerülnek..." (háziorvos, 59).

A fentieken túl érzékelhető egyfajta társadalmi egyenlőtlenség, ami nem csupán a generációs különbségekben és az alkalmazáshoz szükséges készségek hiátusában gyökerezik. 
Sok esetben a technológiai deprivációban is megjelenik, ami feltételezhetően mindenekelőtt anyagi természetü, hiszen „,...nem minden beteg tudja elérni a modern technikát, nem mindenhol van internet otthon, nincs mindenkinek okostelefonja...” (belgyógyász, 40), illetve „...van a betegek részéröl is egy gát, mert például ma volt egy betegem ... és ö is azt mondja, hogy nincs ... számitógépe ... a hardver az probléma, Magyarországon van még mindig egy elég széles kör, aki nem tud használni okostelefont..." (belgyógyász, 52).

Egy további akadálya a telemedicina használatának és terjedésének a potenciális alkalmazó szakemberek attitüdje, idegenkedése, ami részben abból adódik, hogy a távgyógyászat egy másfajta munkaszervezést és módszert igényel, és ezáltal alapvetően megváltoztatja a megszokott klinikai rutint:

„,...nekünk gyökeresen át kellett alakitani a munkánkat, a munkatempónkat, a stílusunkat, a rutinunkat..." (radiológus, 35).

„...leginkább elsöre, úgymond ... a rendszer tehetetlensége, az, hogy a benne dolgozók megszoktak bizonyos munkameneteket és müködéseket és erröl nehezen váltanak..." (radiológus, 17).

A megkérdezett egészségügyi felsővezetők is a legnagyobb akadálynak a szemléletbeli különbséget tartják, ami részben orvos, részben pedig beteg oldalon is jelentkezhet. Noha az „,...emlitett finanszirozási probléma az probléma. Ennél azért én jelentősebbnek érzem, hogy ... ez egy szemléletváltást igényel ... orvosként abban szocializálódtam, hogy ... az orvosnak a beteg mellett a helye..." (egészségügyi felsővezető, 22).

Az sem hagyható figyelmen kívül, hogy a klinikai rutin megváltozása több esetben együtt jár az orvos-beteg kontaktus gyakoriságának csökkenésével, elszemélytelenedésével, ami különösen a radiológiát érinti:

„....az orvosok egy része ezt nem fogadja el, mert kell az a kapcsolat, ami mindenféleképpen változik...” (radiológus, 37).

„...én a legföbb akadálynak tényleg azt tartom, hogy az orvos eltávolodik a betegtöl, és ennek a szubjektív hatásai..." (radiológus, 47).

A fizikai kapcsolatok hiánya azonban nem csupán orvos-beteg, hanem orvos-orvos (és kiváltképpen klinikus-radiológus) relációban is fennáll, ami azért problematikus, mert a megfelelő beteginformáció több esetben egyébként is hiányzik:

„....az úgynevezett klinika radiológiai megbeszélése, ahol több radiológus és klinikus teszi össze a fejét és mindnek a tapasztalata benne van a döntésben, és ezek teljesen kivesztek, és a telemedicina ezt aztán végképp kiöli..." (radiológus, 3 ).

A fentieken túl az időfaktorral is számolni kell, mint esetleges akadályozó tényezővel. Ennek oka abban keresendő, hogy az egészségügyi ellátásban dolgozók egyébként is leterheltek, a telemedicina pedig sok esetben plusz időt és energiát igényel - aminek részben oka lehet a finanszírozás hiánya -, amit az is erősít, hogy a rendszerbe nincsenek beépítve a távgyógyászati elemek:

„,...amikor kint 50 beteg van, akkor nem lehet szürési célzattal elkésziteni mondjuk egy EKG$t$, mert annak van egy ideje és még mindig az adminisztráció, amit nem tudok elviselni..." (háziorvos, 55).

„,...nyilván kapacitás és időhiány, ami leginkább van, tehát miután mindenki csinálja, darálja a vizsgálatait, ezért senkinek már nincs ereje arra..." (belgyógyász, 50).

Az orvosok idegenkedése mellett a páciensek attitüdje szintén egy meghatározó barrierje lehet a telemedicina használatának, ami mindenekelőtt a személyes jelenléten alapuló ellátás preferálásának következménye:

„,...talán az emberek hozzáállása, nem mindenki fogadja el teljes egészében az új dolgokat, kicsit talán idegenkednek töle...” (rezidens, 45). 
„,...egy habitusa a magyar lakosságnak. Szeretik a szemtöl szembe ellátást, tehát a magyar lakosság eléggé úgy van nevelve...” (háziorvos, 31).

$\mathrm{Az}$ interjúpartnerek az előzőeken kívül a távgyógyászati alkalmazások jelentős akadályának tartják a jogi kérdéseket is. Ennek egyik vonatkozása, hogy számos esetben az egészségügyi szakember felelőssége nincs megfelelően definiálva és szabályozva. A telemedicinális ellátáshoz sokszor „,...hiányoznak azok a jogszabályi hátterek: kinek a felelösség, ha rossz a diagnózis? A diagnózis megtörténik és az orvos felelösséget vállal a véleményéért, ki fizeti ki? És igen, és ha téved, akkor mi van? Tehát ilyen jogszabályi hátterei..." (dermatológus, 32). Így problémaként jelentkezhet, hogy a távgyógyászatnak „,...vannak jogi akadályai, személyiségi jogok, illetve adatvédelmi kérdések, amelyek nem minden területen vannak letisztázva...” (radiológus, 5).

A telemedicina jogi aspektusaihoz ugyanakkor hozzátartoznak az etikai kérdések is. A távgyógyászat alkalmazásánál ugyanis szükséges a beteg személyi és egyéb egészségügyi adatainak szigorú védelme, aminek kivitelezése szintén gátló tényezőként jelentkezhet:

„....még biztositani kell nyilván az adatvédelmi dolgokat is. Tehát az, hogy a cserélődő adatok ne menjenek, tehát ne kerüljenek ki, más ne láthasson bele..." (neurológus, 23).

„....leginkább, ami zavaró lehet ... az adatvédelmi szempontok, mert ... ezeken az internetes rendszereken azért ezek az egészségügyi adatok ... azért el-elszaladhatnak...” (idegsebész, 27).

A felelősség kérdése és ahhoz kapcsolódóan a félelem az egészségügyi szakemberekben is felmerülhet. Az orvosi döntést csak megfelelően validált és megbízható adatokra támaszkodva célszerủ meghozni. Az egészségügyi alapfunkciók távoli mérésénél, ahol nincs jelen az ellátó személyzet, néha megkérdőjelezhető az értékek hitelessége. Ebben az esetben ugyanis ,„...egy olyan mérési paraméterre alapozom a döntéseimet, amiröl nem tudom, hogy pontos, akkor ... védtelen leszek ... talán ez az egyik legnagyobb gond, hogy ... az a mérés, az valóban preciz legyen, hozzáteszem, valóban preciz legyen úgy, hogy egyszerü legyen a beteg számára felhasználni..." (neurológus, 30).

Egyes interjúpartnerek szerint további gátló tényezőként lehet számolni az érdek összeütközésekkel is. Tekintettel a telemedicina finanszírozási problematikájára és a közvetlen orvos-beteg találkozók elszámolására, nem feltétlen kifizetődő az intézmények számára a távgyógyászat alkalmazása:

„....úgy látom ... hogy ... az egészségügyi szolgáltatók ellenérdekeltek, tehát a szolgáltatók abból kapják a pénzt, hogy a beteggel találkoznak ... és minél bonyolultabb kapcsolatba kerülnek vele..." (szülész-nőgyógyász, 1).

„,...anyagi érdekek ... a menedzsment, vagy a vezetöség. Most nyilván ebbe beleérthetö nyugodtan a röntgen osztály, vagy a megfelelö osztálynak is az ellenállása..." (radiológus, 20).

A telemedicina alkalmazását és terjedését a felsorolt tényezőkön felül befolyásolhatja az adott egészségügyi intézmény informatikai felkészültsége, az infokommunikációs technológiák minősége, a kórházi rendszerek kompatibilitása.

Általában az interjúpartnerek a távoli intézményekkel való kommunikációs és adatmegosztási problémákról számolnak be, ami e rendszerek heterogenitásából fakad. Ráadásul sok esetben elavultak a gépparkok, amelyek telemedicinális szolgáltatás nyújtására rendszerint nem alkalmasak:

„....nincs központi adatkezelés, hanem minden egyes ellátó a saját adatbázisát épitgeti, és azok egymással egyáltalán nem kommunikálnak...” (dermatológus, 53).

„....tehát két különbözö rendszer között semmilyen átjárás nem biztositott ... ez velünk úgymond kitolás, erösen..." (radiológus, 9). 
Ugyanakkor vannak olyan egészségügyi intézmények is, amelyek az interjúpartnerek meglátása szerint infrastrukturálisan alkalmasak a telemedicinális lehetőségek optimális kihasználására:

„,...viszonylag jó központi informatika ... egy hihetetlen profi informatikus, tehát nekünk nincs ezzel gondunk..." (radiológus, 35).

„,...egyik legjobban felszerelt és felkészült kórház, én azt gondolom, hogy nálunk minden hardver és adott esetben szoftver rendelkezésre áll..." (sebész, 14).

Ráadásul megjelenik egy olyan - az előzőekkel ellentétes - nézet is, miszerint a heterogén hálózatok ellenére meg lehet teremteni annak a lehetőségét, hogy távoli intézmények kollégái felhatalmazás címén, szükség esetén hozzáférhessenek az ország más részén müködő egészségügyi szolgáltatók betegeinek az adataihoz. Így ez nem lehet akadálya a távgyógyászatnak, noha az ehhez szükséges kooperációt ki kell alakítani „,...tehát bármelyik kórház képes bármelyik kórházzal kommunikálni a saját rendszerével, ha ez cél. Biztos, hogy dolgozni kell rajta..." (idegsebész, 25).

A térbeli terjedés akadályain kívül érdemes röviden elemezni a távgyógyászat kialakulására ható tényezőket is. Különös tekintettel arra, hogy mely faktorok determinálják egyes helyeken és intézményekben a telemedicina adaptálását, illetve alkalmazását és melyek gátolják más helyeken, ahol nem használják a távgyógyászatot.

Az interjúpartnerek többsége analóg tényezőkről számol be, amelyek ennek megfelelően homogén csoportokba sorolhatók. Az interjúalanyok közül különösen a radiológusok tekintik mérvadó tényezőnek a szakemberhiányt, illetve annak mértékét.

Álláspontjuk szerint ugyanis noha az orvoshiány a legtöbb egészségügyi intézményben jelen van, nem mindenhol azonos szinten. Ebben a tekintetben többen érzékelnek egy kritikus pontot, ahol szükségessé válik a hiányt valamelyest pótolni az ellátás biztosítása érdekében, és erre szolgálhat bizonyos mértékig megoldást a távleletezés. Az adaptálás , ,...inkább az orvosi létszámtól függ, az, hogyha valahol megszorultak egyszer és rákényszerültek úgymond igénybe venni ... ezt a szolgáltatást, attól a perctöl kezdve már megszokják és megszeretik..." (radiológus, 20). Ugyanakkor „...az intézmények akkor lépnek, ha rákényszerülnek. Vagy hiány, vagy ... adott esetben kisebb kórházak ... a nagy kórháztól veszik a szakértőt..." (idegsebész, 25).

Az interjúpartnerek egy másik csoportja szerint a személyi tényezők határozzák meg a telemedicina adaptálását és használatát. Ebben a tekintetben különösen releváns a potenciális alkalmazók attitüdje, motivációja, affinitása a távellátás iránt. Ráadásul szükséges egyfajta igény és késztetés az ellátás minőségének javítására:

„Azt gondolom, hogy ambició kérdése, meg személyes érdeklödés, aztán ... ha az embernek a környezetében elkezdik-e használni az rajta is múlik...” (belgyógyász, 63).

„,...lehet nyitottság kérdése is, hogy most mennyire nyitott az illetö, sokan szkeptikusak ezzel kapcsolatban..." (belgyógyász, 46).

Ehhez kapcsolódóan szintén releváns az intézményi menedzsment hozzáállása a telemedicinához. A sikeres adaptáláshoz megfelelően nyitott és fogékony vezetőség és a döntést támogató dolgozók egyaránt szükségesek. Amennyiben valamelyik fél nem kellően nyitott, ott a távgyógyászatot valószínüsíthetően nem lehet sikeresen müködtetni. A telemedicina bevezetéséhez pedig sokszor nélkülözhetetlen lehet a megfelelő lobbi tevékenység is:

„....azon múlik, hogy valaki akár intézményvezetőként ... egy kórházon belül egy osztálynak a vezetöje az mennyire motivált ebben a témában, és motiválja-e önmagát, meg a vele dolgozókat, vagy sem..." (háziorvos, 41).

„....a vezetöség hozzáállása, mennyire nyitott az új dolgokra, mennyire tudják ezt átvinni a beosztottjaikra..." (rezidens, 45). 
Ráadásul az érintettek attitüdjén felül a megfelelö infrastrukturális ellátottság is releváns a telemedicina adaptálásához. Továbbá ezek megteremtéséhez szükséges financiális feltételek. Azokban az intézményekben, ahol az alábbi erőforrásokhoz könnyebben hozzáférnek, nagyobb valószínüséggel alkalmazhatják a távgyógyászatot is. Ebből adódóan az adaptáció „,...mindenféleképpen [függ] attól, hogy ... hogyan tudják biztositani az ehhez szükséges technikai feltételeket..." (radiológus, 37). A hosszútávú és sikeres telemedicinális ellátásnak „...van némi anyagi, illetve eszköz vonzata is, tehát nyilván ehhez be kell ruházni...” (belgyógyász, 49).

Összességében elmondható, hogy a telemedicina terjedését és alkalmazását számos vélt és valós tényező gátolja. Ezek általában a finanszírozáshoz, a szükséges technikához, az érintettek attitűdjéhez, készségeihez, kvalitásaihoz, továbbá a jogi, etikai és adatvédelmi szempontokhoz köthetök.

Noha egyes interjúpartnerek - kortól, szakterülettől, intézményi hovatartozástól, érdekeltségtől, tapasztalattól függően - eltérő szerepet adnak e tényezőknek, ezek azok, amelyek leginkább determinálják a telemedicina használatát, továbbá egy sereg más egyéb faktor.

Azt is érdemes figyelembe venni, hogy egyes területeken az orvoshiányból fakadó kényszerhelyzet generálja a távgyógyászat alkalmazását (lásd távleletezés), ezért az akadályok valamelyest gyorsabb redukálását segíti. Míg azokon a szakterületeken, ahol inkább a páciensek paramétereinek távoli monitorozása, így az ellátás minőségének javítása a cél, ott sokkal vontatottabban halad, és sokszor csupán lokális, egy-egy elhivatottabb szakember kezdeményezéseként interpretálható.

GIDDENS strukturációs elméletének megfelelően az egészségügyi struktúra korlátozhatja és lehetővé is teheti a telemedicina adaptálását. Ezt mindenekelőtt a források, a rendelkezésre álló kapacitások, illetve a különböző szabályok, rutin eljárások determinálják. A telemedicinát potenciális alkalmazói a fenti tényezők, illetve általában a társadalmi következmények figyelembevétele mellett döntenek a távgyógyászat használata mellett, vagy ellen. A telemedicina adaptálása esetén a korábban bevett gyakorlatok - mint amilyen a klasszikus (fizikai jelenléten alapuló) orvos-beteg találkozók is - módosulnak (GIDDENS, A. 1984).

\subsection{A telemedicina egészségügyi egyenlőtlenségekre gyakorolt hatásai}

Az egészségügyi ellátórendszer számos egyenlőtlenségi problémával rendelkezik, ami magában foglalja a finanszírozási, területi, szervezeti, infrastrukturális, humánerőforrás hiánnyal kapcsolatos nehézségeket (OROSz É. 2001).

Ebből adódóan egy releváns kérdés, hogy a telemedicina miként jelenik meg a mindennapi ellátásban és milyen hatással bír a fenti egyenlőtlenségekre? Továbbá azt is érdemes szem elött tartani, hogy maguk az egészségügyi szakember miként tapasztalják a távgyógyászat hatásait, vajon ténylegesen mérsékli az egyenlőtlenségeket, vagy sokkal inkább újratermeli?

Feltehetően a válasz sokkal komplexebb annál, mintsem, hogy állást lehessen foglalni egyik, vagy másik kategória mellett. Maguk az interjúpartnerek is megosztott állásponton vannak a témát tekintve. Szempontjaikat valószínüsíthetően számos tényező determinálja, csakúgy, mint az életkoruk, szemléletük, praxisukban eltöltött idő, telemedicinával kapcsolatos tapasztalatuk és elégedettségük, szakterületük, esetleges érdekeltségük.

$\mathrm{Az}$ interjúpartnerek több mint a fele részletesen kifejti e témakörrel kapcsolatos álláspontját. Az interjúalanyok egy jelentős csoportja szerint a telemedicina egyik részterülete a teleradiológia képes csökkenti az egészségügyi egyenlötlenségeket, azon belül is az orvoshiány okozta területi differenciákat. Ez pedig a távgyógyászat hatékonyságára vezethető vissza, ami egyúttal gyorsítja is az ellátást: 
„,... a radiológiai ellátásra gondolok ... akkor ezeket a különbségeket elsimitja. Egyértelmüen. Elsimitja, ha jól csinálják..." (radiológus, 7).

„... annyiból biztos, hogy képes csökkenteni, hogy azért hogyha nem lenne most a telemedicina, akkor még hosszabbak lennének a várólisták ... ez ilyen szempontból ez abszurd gyors..." (radiológus, 6).

A humánerőforrás hiány mérséklése pedig a teleradiológiában egyet jelent a speciális klinikai szakértelem optimális eloszlásával. A specialisták általában a magasabb progresszivitású intézményekhez, egészségügyi centrumokhoz köthetők, de a tevékenységük az infokommunikációs technológiáknak köszönhetően távoli térségekre is kiterjed. A telemedicina során tehát „,...ez is az egyik fö cél, tehát nemcsak az orvoshiány, tehát nemcsak földrajzi, hanem szaktudásbeli egyenlötlenség [mérséklése], ugyanis ez mind az esélyegyenlöség felé mutat...” (radiológus, 42). A teleradiológia „,...mindenképpen a munkaerő elosztásban ... segíthet. Ez hívta életre tulajdonképpen ... azok a specialisták, akik a központokban dolgoznak, az ö munkájuk is sokkal inkább elérhetövé válik..." (radiológus, 17).

Annak ellenére, hogy a teleradiológia számos jótékony hatással rendelkezik, egyes interjúalanyok mégsem tekintik teljes megoldásnak a szakemberhiányra. Ennek okát az orvosi létszámban megmutatkozó jelentős (abszolút és relatív) deficitben látják. Noha ez növelheti a havi jövedelmét a leletezőnek, negatív aspektusokkal is társulhat, hiszen hozzájárulhat a szakorvosi leterheltség növekedéséhez:

„....kicsit csökkenti ezeket az egyenlötlenségeket ... átmenetileg ugyan megoldja a problémákat, de véglegesen nem tudja megoldani. Attól még mindig csak x orvos lesz itt és azok közül bármikor történhet bárkivel bármi..." (radiológus, 20).

„...a helyi hiányokat valamennyire próbáljuk megszüntetni, meg orvosolni azzal, hogy van egy centrum, ahol talán annyi ember dolgozik, aki ... el tudja látni a kisebb, külső régiókat is, de teljesen nem oldja meg...” (radiológus, 9).

Egyik egészségügyi felsővezető szerint is a telemedicina az egészségügyi ellátás területi egyenlőtlenségeinek - különös tekintettel az orvoshiányra - enyhítésére szolgál, ennek ellenére szintén nem tartja optimális megoldásnak, mivel a településhálózat egyes tagjai között a differencia továbbra is konzerválódik. Álláspontja szerint nagyobb térségek esetében lenne szükség az egyenlőtlenség mérséklésére, azonban ez már nem csupán ellátásbeli, sokkal inkább gazdasági eredetü és „...ezek a földrajzi különbségek ... településszerkezeti különbségek nem szüntethetöek meg, nyilvánvalóan mérsékelhetők a hatásai. Tehát igazából nem azokra a földrajzi egyenlötlenségekre kellene elsösorban odafigyelni, amik településszerkezeti eltérésböl adódnak, hanem mondjuk ... észak, vagy dél, vagy nyugat, vagy kelet..." (egészségügyi felsővezető, 22).

A teleradiológián kívül a telemedicina egyéb területei is pozitív hatást gyakorolnak az egyenlőtlenségekre. A telemedicina az egészségügyi ellátás hozzáférhetőségét javítja olyan térségekben, ahol ez nem megfelelö, és amit az infokommunikációs technológiák fizikai távolságot „redukáló” hatása generál:

„....pont a földrajzi távolságoknak az áthágását, áthidalását eredményezi. Úgyhogy én biztos vagyok, hogy csökkentö, kedvezö hatása van..." (kardiológus, 24).

„...van egy betegcsoport, akik ... nem fér be hozzá ... de telemedicinális segítséggel megoldható, akkor az ... egyenlötlenséget természetesen csökkentheti...” (belgyógyász, 52).

Egyes interjúalanyok szerint azonban az egészségügyi egyenlőtlenségeket mérséklő hatások csak abban az esetben érvényesülhetnek, ha ez az egész ellátórendszert érinti és beépül a klinikai rutinba. Így ha csupán lokális kezdeményezések indulnak és azok nem kapcsolódnak egy egységes informatikai rendszerbe, az csak rövidtávú projekteket fog eredményezni, amelyeknek a hatása nem kvantifikálható: 
„,...ha ez rendszerszinten megjelenne és beépülne ... és elérhetövé válna ... gyorsitani tudná az ellátást, illetve az adott lakosságnak az ellátáshoz történő hozzájutását..." (háziorvos, 44). „Amennyiben bekapcsolódnak ... egy közös struktúrába és ténylegesen tanácsokat kérhetnek egymástól, képeket átküldhetnek, akkor az elmaradottságok egyenlitödhetnek..." (belgyógyász, 40).

Ugyanakkor megjelenik egy olyan szemlélet is, miszerint a telemedicina nem képes pótolni azokat a forrásokat, amelyek ma az egészségügyi egyenlőtlenséget okozzák. Egyik interjúpartner szerint ez mindenekelőtt annak köszönhető, hogy e tényezők a telemedicinális szolgáltatásokban is egyfajta barriert képeznek, nem csupán a klasszikus ellátásban:

„...lehetöség lenne arra, hogy kiegyenlitse, viszont ami miatt kialakulnak ezek az egyenlötlenségek, esetleg azok a telemedicina elérhetöségét is nehezítik az adott lakosságcsoportok számára..." (háziorvos, 62).

„,...azokat a problémákat, amelyek jelenleg fönnállnak, azokat nem fogja enyhiteni a telemedicina, mert sem orvos nem lesz több, sem eszköz nem lesz több...” (belgyógyász, 49).

Ráadásul az interjúpartnerek egy csoportja szerint a távgyógyászat újra is termelheti az egészségügyi egyenlőtlenségeket, mivel szórtan müködik, bizonyos térségekhez, településekhez köthetően és nem az egész országot lefedve.

$\mathrm{Az}$ egészségügyi egyenlőtlenség területi mintázata általában korrelál a gazdasági elmaradottsággal, és ez megmutatkozik az infokommunikációs technológiák térbeli vetületében is, ami a telemedicina alkalmazásának feltétele:

„,...jelen pillanatban növeli az egyenlötlenséget, mert a hozzáférés nem egyforma ... jó esetben csökkentené, pont fordítva történne...” (szülész-nőgyógyász, 1).

„,...hozzáadunk ... egy egészségpolitikai egyenlötlenséghez még egy IT egyenlötlenséget is..." (neurológus, 30).

A fentiekhez kapcsolódva néhány orvos szerint a telemedicina egyszerre redukálhatja és generálhatja is az egyenlőtlenséget. A távgyógyászatban ez a dichotómia megosztja a társadalmat: azokra, akik hozzáférnek a telemedicinához, így jobb minőségü ellátásban részesülhetnek és azokra, akik valamilyen oknál fogva marginalizálódnak. Így „,..egyik oldalról akár a szakadék nőhet ... azok, akik jól tudják ezeket a rendszereket átlátni, és használni, még könnyebben ... jutnak ellátáshoz és ... és akiknek ezekre nincsen lehetöségük, azok még inkább leszakadnak...” (háziorvos, 41). Illetve „,...távolít is, meg közelit is. Tehát az, aki nem tudja használni a telemedicinát az lemarad, aki meg tudja használni az bárhol van, nyer rajta...." (háziorvos, 59).

A páciensek esetében egyébként is számos tényező akadályozhatja a telemedicinális szolgáltatások - mindenekelőtt a távfelügyelet - igénybevételét. Ez egyrészt visszavezethető a távgyógyászat finanszírozására. Tekintve, hogy a távoli monitorozás költségeit sokszor a betegeknek kell kompenzálni, így egy jelentős részük kirekesztődik:

„,...akinek van 'lóvéja' az igénybe veszi ... bérbe adjuk, üzleti alapon történik, akinek meg nincsen pénze ... nagyon meg kell gondolnia...” (szülész-nőgyógyász, 1).

„.... a mélyszegénységben élők, azok nagyon nem jutnak hozzá, korlátozottak az egyedül élö, idös emberek..." (háziorvos, 44).

$\mathrm{Az}$ interjúpartnerek egy jelentős csoportja a távgyógyászat igénybevételét korosztályfüggőnek tartja. Álláspontjuk szerint a telemedicina tekintetében is létezik egyfajta generációs szakadék idősek és fiatalok között. Általában az idősek - különböző okokból kevésbé preferálják a modern technika alkalmazását, különösen az ellátás területén. Ezért annak kedvező hatásait sem élvezik, noha sok esetben szükségük lenne rá. Inkább , ,..a fiatalabbak [fogékonyak], akik amúgy is használják az internetet, van okos telefonjuk ... azokat nyilván könnyebben rá tudom erre venni. Míg az idösebbek lehet, hogy úgy érzik biztonságosnak, ha bejönnek...” (belgyógyász, 46). Tehát „...az idősebb generáció, azt 
gondolom, hogy részben technikai okok miatt, részben pedig esetleges bizalmatlanság miatt is inkább ők a személyes...” (dermatológus, 53) ellátást részesítik előnyben.

A telemedicinális szolgáltatások igénybevétele egyébként is feltételez egyfajta készséget és képességet az infokommunikációs technológiák használata iránt. Ez pedig általában magasabb iskolai végzettséget sejtet, amihez rendszerint magasabb egészségkultúra is társul.

Az egészségtudatosabb betegek számára az egészség jelentős értéket képvisel, csak úgy, mint annak megőrzése, illetve a prevenció, amit a telemedicina használata támogat. Azok a páciensek tehát, akik nem rendelkeznek az infokommunikációs technológiákhoz és különösen az internet használatához szükséges ismerettel és jártassággal, azok marginalizálódnak:

„....nyilván kell egy bizonyos fokú iskolázottság, vagy alapképzettség ahhoz, hogy internet felhasználó legyen valaki..." (szülész-nőgyógyász, 39).

„...egyértelmü az összefüggés, hogy minél inkább magasabban kvalifikált valaki, annál inkább nyitott ezekre a kérdésekre..." (háziorvos, 41).

Az előzőeken túl az egyenlőtlenség az infrastrukturális tényezők esetében is megfigyelhető a telemedicinális ellátás során. Ezeket nem a távgyógyászati tevékenységek generálják, hanem az egészségügyi ellátórendszer területi differenciáihoz köthetők, de a mérséklésükön sok esetben a telemedicina sem segít:

„....Magyarországon nagy egyenlötlenség van technikai részekben, és ... a kórházak között is nagy különbségek vannak..." (radiológus, 37).

A müszaki-technikai tényezők a távgyógyászat minden területén meghatározók, de különösen lényegesek a teleradiológiánál. A távleletezés során ugyanis nagyméretü képanyagokat küldenek - általában az alacsonyabb progresszivitású intézményből a magasabb ellátási szinten lévőbe - egyik intézményekből a másikba információs technológiákon keresztül, ezért az internet nagy sávszélessége, megbízhatósága elengedhetetlen mind a küldő, mind pedig a fogadó oldalon. Ellenkező esetben ez gátat szab a telemedicinális ellátásnak, így azokban az egészségügyi intézményekben, ahol nem tudják biztosítani - különböző, mindenekelőtt anyagi okokból - a szükséges müszaki feltételeket, kimaradnak a távleletezésből. Így „...olyan szakrendelőkben nem tudtuk ezt bevállalni, akiknek ... a feltöltési sávszélessége, az nagyon alacsony volt..." (radiológus, 7). Az ellátást megnehezíti, ha egy helyen „,...három óra hosszáig tart, míg egy mellkas röntgenképet föltöltenek...” (radiológus, 12).

A teleradiológia egyébként is feltételez egy infrastrukturális minimumkövetelményt, ami nélkül nem funkcionál. Ez magában foglalja az előzőekben ismertet internettel kapcsolatos paramétereket, a digitális technológia meglétét stb. Ugyanakkor az elkészült képanyag minőségének diagnosztikai befolyásoló hatása is lehet, ezért nem mindegy, hogy milyen készülékkel, milyen felbontással készülnek az egyes felvételek. Így ezek az infrastrukturális egyenlőtlenségek valamelyest a telemedicinális ellátás során is konzerválódnak:

„....nem mindegy, hogy egy milyen minöségü képet kell leletezni, és az se mindegy nyilvánvalóan, hogy aki leletezi, milyen monitoron nézi...” (radiológus, 11).

„.....nagyon fontos, hogy jó minöségü képekkel dolgozzunk, mert az jelentösen javít a vizsgálat értékelhetöségén..." (radiológus, 20).

E témakört tovább elemezve azt is érdemes figyelembe venni, hogy a telemedicinális szolgáltatások egyesek szerint egyenlőtlen felek között valósulnak meg. Ez azt is jelenti, hogy a már meglévő intézményi és szakmai hierarchia oldásában nem hoz számottevő változást a telemedicina. Ugyanis a távgyógyászati ellátásban is meghatározó szerepet tölt be a szakmai implicit tudás, azonban az ezeket birtokló expertek a magasabb progresszivitási szintü intézményekben tevékenykednek. Így lesznek, akik direkt hozzáférnek a klasszikus ellátás keretében e szaktudáshoz és lesznek, akik csak a „távolból” profitálnak belőle: 
„,...a telemedicina általában egyirányú, tehát gyengébben felszerelt, szegényesebb szakember ellátottságú kicsi kórház akar kommunikálni a nagy klinikával, vagy nagy megyei kórházzal..." (neurológus, 23).

„...általában a kooperáció alulról indul, tehát általában az alacsonyabb progresszivitási szintröl kérnek segítséget a magasabb felé...” (idegsebész, 27).

Tekintettel arra, hogy az egyenlőtlenség számos módon értelmezhető, a telemedicinának pedig szerteágazó hatásai vannak, így e témakör is komplexen kezelendő. Nem lehet tehát egyszerüen értékelni a távgyógyászat egyenlőtlenségekre gyakorolt impulzusait, ugyanis egyes esetekben mérsékli, más szituációkban és vonatkozásokban akár növelheti is. Lényegében az empirikus eredmények a telemedicina nemzetközi szakirodalmában megjelent, egyenlőtlenségekre gyakorolt hatásainak pozitív (pl. MATUsitz, J. - BREEN, G.M. 2007) és negatív aspektusait (pl. CARTWRIGHT, L. 2000) is igazolják részben.

Annak ellenére, hogy a telemedicina talán teljes megoldást nem nyújt a szakemberhiányra és annak területi aspektusaira, jelentősen mérsékelheti az ellátás orvoshiányból fakadó egyenlőtlenségeit, amire leginkább a teleradiológiában van példa. Olyan helyeken is hozzáférnek a speciális klinikai szakértelemhez, ahol hiátus van, és ami egyébként csak a centrumokban és magasabb progresszivitási szinten lévő intézményekben lenne helyben elérhető.

Noha a telemedicina feltehetően nem fogja pótolni a hiányzó orvost, de hatékonyabbá teheti az egészségügyi ellátásban dolgozók munkáját, így optimális eloszlást biztosíthat a központoktól távoli térségekben is. A távfelügyeleti szolgáltatásoknál is biztosan kell egy szakember, aki monitorozza a páciensek adatait és szükség esetén beavatkozik, mégis redukálhatja a személyes orvos-beteg találkozók számát.

Ugyanakkor azok, akik valamilyen okból - legyen az alacsony jövedelem, magasabb életkor, az infokommunikációs technológiákhoz szükséges készség és jártasság hiánya stb. nem férnek hozzá a telemedicinális ellátáshoz (mindenekelött a távfelügyelethez), azok egyenlőtlen helyzetbe kerülnek, azokhoz képest, akik ezáltal jobb minőségü, sok esetben kiegészítő ellátáshoz jutnak. A távgyógyászathoz szükséges infrastrukturális tényezők területi differenciái pedig bizonyos telemedicinális ellátási formáknál szintén befolyásolhatják a szolgáltatás minőségét és akár a használatának a lehetőségét is korlátozhatják.

\subsection{A telemedicina orvos-beteg kapcsolatra és az egészségügyi szakemberek közötti viszonyra gyakorolt hatásai}

A telemedicinának talán az egyik legszembetűnőbb hatása az interperszonális viszonyrendszer változásaként fogható fel. Noha különbözőképpen, de a távgyógyászat befolyásolja az orvos-beteg kapcsolatot és két egészségügyi szakember - ahol nem kizárólagosan orvos mindkét résztvevő - közötti kontaktust is.

Az orvos-páciens kapcsolatról az interjúpartnerek (kevés kivételtől eltekintve) kielégítően és részletesen fejtik ki álláspontjukat. Míg a szakemberek közötti kontaktusnál ez az arány az interjúalanyoknak „,csupán” felét érinti. Ezek az értékek a témakör iránti érdeklődés mértékét is mutathatják. Ebből adódóan mindenekelőtt az orvos-beteg viszonyrendszer változására és átértékelődésére fókuszálok, kitérve annak negatív és esetleges pozitív aspektusaira egyaránt.

A képalkotó diagnosztikában másként értelmezhető e viszonyrendszer átalakulása, mint a többi orvosi szakterületen. A teleradiológiában lényegében megszünik az orvos-beteg kapcsolat, hiszen a páciens általában az orvossal nem találkozik a vizsgálat elvégzése során: „....a leletezö orvos az teljes mértékben eltávolodik az ellátó helytöl és mindenféle vonatkozásától. Úgyhogy gyakorlatilag a távleletezö orvos és a beteg tulajdonképpen semmiféle kapcsolatban nincs egymással..." (radiológus, 17). 
„,...a távdiagnosztikában meg, mivel nem is találkozunk a betegekkel, nyilván olyan nagy orvos-beteg kapcsolatról nem lehet beszélni..." (radiológus, 11).

Ugyanakkor egyes interjúpartnerek állítása szerint a radiológiában sosem volt igazán erős a szakorvos és a páciens közötti kontaktus. A beteg a legtöbb esetben az egészségügyi szakszemélyzettel, asszisztenciával találkozott, az orvoshoz pedig csupán a páciens lelete jutott. Így „...hozzáteszem a radiológiában régen sem biztos, hogy látta [a radiológus a beteget], mert a röntgen asszisztens bevitte az orvosnak a röntgen filmet, az ránézett..." (radiológus, 5). Ezt egy másik radiológus is megerősíti, miszerint „,...tulajdonképpen soha nem volt igazi orvos-beteg kapcsolat, mert a vizsgálatokat általában asszisztensek végezték, akik beszélgettek a betegekkel..." (radiológus, 37).

Ebben a tekintetben két ellentétes nézet kerül egymással szembe a telemedicina egyik területén, a teleradiológiánál. Egyrészt megjelennek azok az orvosok, akik problémának tekintik, hogy nem léphetnek fizikai kapcsolatba a beteggel, és így kevésbé preferálják e viszonyrendszer redukálódását, mégha azt a humánerőforrás hiány okozta kényszer miatt el is fogadják:

„.... a beteg-orvos viszony a nullára csökken ... ez egy technikus, tehát itt az orvos visszaléptette saját magát..." (radiológus, 21).

„...teljesen kiszakad az orvos a vizsgálatnak a folyamatából, hanem csak egy ilyen utólagos véleményezövé válik, és ... én ezt hiányolom..." (radiológus, 47).

$\mathrm{Az}$ interjúpartnerek másik csoportja szerint viszont a radiológiában nem minden szituációban van szükség a páciens és az orvos találkozására a megfelelö ellátáshoz, csak az esetek elenyészö részében:

„...hagyományos röntgen diagnosztikába ez nem gond. Aki azt mondja ... az arra a húsz százalékra..." (radiológus, 7).

„....nem azt mondom, hogy nincs szükség a radiológus esetén orvos-beteg találkozásra, de ... azt viszont mondom, hogy, hogy nagyon sokszor ez nem adna plusz információt..." (radiológus, 42).

A távleletezésnél az egyik legfőbb problémát több interjúpartner szerint a pácienst érintő klinikai információ hiánya, illetve elégtelensége jelenti. Ezt részben orvosolja a képzett asszisztencia, aki a beteggel tartja a kapcsolatot és kiegészítő megjegyzéseket tesz a leletezőnek. Viszont amennyiben mégis szükség van a beteget közvetlen ellátó orvossal való konzultációra - tekintve, hogy sokszor egy külső, távoli intézményben dolgozó klinikusról lévén szó -, annak elérése további nehézséget okozhat. Tehát „,...ha itt nem ilyen lenne az asszisztencia és nem írnák le az információkat email-be, akkor gyakorlatilag az orvos semmit nem tudna a betegröl..." (radiológus, 13).

A fentiekhez kapcsolódva egy etikai kérdés is felmerül, ugyanis a páciensek többsége nem biztos, hogy értesül arról, hogy egy távoli intézmény orvosa látja el. Ebben a tekintetben szükséges lenne minden esetben a beteg informálása, noha egyes interjúpartnerek szerint feltehetően nem is mutatnak eziránt különösebb érdeklődést a páciensek:

„....szerintem a betegek ilyen szempontból kiszolgáltatottak, mert ... szerintem jelentös részük lehet, hogy nem is tudja, hogy az ö lelete távleletként született meg..." (radiológus, 3).

„....szerintem a betegeknek tulajdonképpen mindegy, mert úgy is csak az a lényeg, hogy neki a kezében legyen egy lelet..." (radiológus, 18).

Ugyanakkor egy másfajta nézőpont szerint a páciensek ezt nem biztos, hogy fél várról fogadják, és akár elégedetlenek is lehetnek, amennyiben tudomást szereznek arról, hogy ellátásuk nem helyben történik, hiszen az orvos fizikai jelenléte megszokott az ellátásban, abban az esetben is, ha éppenséggel nem kerül kontaktusba a beteggel. Ugyanis „,...amikor azt látják [ a páciensek], hogy nincs orvos azon a helyen, ahol óket megvizsgálták, és majd valaki egyszer megleletezi valahol, az még most manapság egy negatívum...” (radiológus, 12). 
Egy alapvetően másfajta orvos-beteg viszonyrendszert feltételez a telemedicina egyéb távleletezésen kívüli - területei. Az egyes távfelügyeletei szolgáltatások alkalmazása előtt az orvos találkozik a páciensével. Sőt ennek előzményeként sokszor akár több éves bizalmi kapcsolat szükséges mindkét fél részéről:

„,...ugyanúgy meg van a bizalom, ennek elözménye az, hogy már egyszer fizikálisan is találkoztak..." (szülész-nőgyógyász, 39).

„,...csak olyan beteg esetében döntök ... telemedicinális eszközök használatában, akivel már személyesen találkoztam ... és úgy látom, hogy annyira megbizható, együttmüködö, hogy bátran dönthetek úgy ... hogy legyenek virtuális..." (belgyógyász, 46).

Egyes interjúpartnerek szerint az orvos és beteg közötti kapcsolat a távfelügyelet során semmiképpen sem erodálódik, sokkal inkább erősödik. Az interperszonális viszonyt támogatja a távoli kapcsolattartás és viszont, ami növeli a páciens biztonságérzetét. Ennek eredményeként „...szerintem az orvos-beteg kapcsolat az mélyül, egyrészt kialakul a betegekben egy ilyen, hogy neki még ez is van ... tehát mindenképpen a bizalmat növeli, szerintem az ellátás biztonságosságát is szolgálja...” (háziorvos, 58). Amennyiben „...van a reguláris betegellátásom, és ... amellé még rakok ... egy telemedicinás monitorizálást is ... ez gyakrabban van, mint ahogy egyébként hozzám eljut ... az erösitheti is az orvos-beteg kapcsolatot..." (neurológus, 30) és nem gyengíti.

A betegbiztonságon kívül minőségi változást hoz a betegek életében a telemedicina, ami abból is adódik, hogy a páciens nem csupán passzív szemlélője lesz gyógyulásának, hanem aktív részese, vagyis bevonják az egészségi állapotának menedzselésébe, ami pozitívan hat egészségkultúrájára, betegségfelismerö képességére is:

„....egyértelmüen jobb a compliance-a a betegeknek, és az egészség- vagy betegtudata is jobb..." (háziorvos, 44).

Egy további releváns kérdés, hogy miként viszonyulnak az orvosok és a betegek a fizikai kontaktusok számának redukálódásához és a távellátáshoz. Egyes interjúpartnerek szerint a páciensek sokszor nagyobb affinitással rendelkeznek a távoli kapcsolatok fenntartása iránt, mint maguk az egészségügyi szakemberek.

Noha megjelennek olyan álláspontok is, miszerint a betegeknél is megfigyelhető a kettősség a telemedicinális kapcsolatokat illetően. Mindenesetre egyfajta igény mutatkozik az egészséggel kapcsolatos teendők és tényezők iránt, aminek kielégítésére az egyik leggyorsabb és talán legegyszerübb megoldás a telemedicina is lehet. Így „... a betegek részéről van egyre nagyobb igény, tehát az orvosi társadalom részéröl szerintem lehet, hogy egy picit nagyobb az ellenállás...” (dermatológus, 53). Általában „,... a beteg az igazából nagyon szeretné azt, ha Öneki bármilyen problémája van, azonnal arra a problémára választ kapna..." (belgyógyász, 49).

Ugyanakkor ebben a tekintetben felmerül az egyenlötlenség témaköre is, mivel nem mindenki egyforma nyitottsággal fogadja. Ennek oka mögött pedig részben generációs szakadék húzódik meg, részben pedig az információs technológiákhoz való készségek hiátusa. Ebből adódóan a fiatal és kora középkorú generáció feltehetően jobban - de nem kizárólagosan - preferálja az orvosával való telemedicinális kapcsolattartást:

„....aki fiatal, vagány, ismeri a számitógépet, internethasználó, okostelefonhasználó, ök abszolút nyitottak..." (belgyógyász, 52).

„.... a fiatal generáció teljesen, aki ugye ebbe nö bele, ebbe a digitális világba, és még nem is jelent meg igazából a beteg oldalon az a mai digitális generáció..." (belgyógyász, 63).

$\mathrm{Az}$ orvos-beteg kapcsolat változása mellett érdemes valamelyest kitérni az egészségügyi szakemberek közötti kontaktus esetleges módosulására is. Ezen belül különösen releváns a hierarchia megjelenése, vagy éppen megszünése az érintett felek között. 
$\mathrm{Az}$ interjúpartnerek többféle álláspontot képviselnek. Többek szerint az egészségügyi ellátórendszert hierarchikus struktúra jellemzi, ami érinti az orvostársadalom tagjait és ez hatással lesz a telemedicinára is. Vagyis a távgyógyászatban is számolni kell az aláfölérendeltséggel, még akkor is, ha ez kevésbé manifeszt:

„...egy diagnózis alapját képezi egy kezelésnek, ott azért megvan a felelössége annak, aki ezekben a kérdésekben nyilatkozik. S ez hierarchia nélkül nem képzelhetö el..." (szülésznőgyógyász, 36).

„Magyarországon porosz rendszer van, tehát ez egyértelmü, hogy hierarchikus a viszony...” (háziorvos, 62).

Ezzel teljesen ellentétes az az álláspont, miszerint a telemedicina esetében nem jelentkezik az egészségügyben általában uralkodó hierarchikus viszony. Ez - egyesek szerint - azért sem lehetséges, mert az egyben akadályát is képezné a távgyógyászat alkalmazásának, ugyanis „....szerintem a kollegák jelentös része nem, nem vesz igénybe olyan szolgáltatást, ahol hierarchiára épül a dolog." (háziorvos, 44). Ezt egy másik háziorvos is megerösíti, aki szerint „...itt nincs alá-fölérendeltség, kórházi orvos, szakrendelöi orvos, háziorvos ... mindenkinek a beteg érdekét kell nézni, és csak igy lehet dolgozni..." (háziorvos, 51).

Ehhez kapcsolódóan a telemedicina általában szakmai konzultációt jelent egy bizonyos specifikummal foglalkozó kollégával. Ez azonban sokkal inkább kooperáción alapuló partneri kapcsolatot feltételez, ami nem szigorú szabályok szerinti utasítást, hanem esetmegbeszélést és szubjektív véleménykérést jelöl:

„,...az egészséges távgyógyászatban nincs ... ilyen hierarchikus kapcsolat, hanem kollegiális kapcsolat van..." (szülész-nőgyógyász, 1).

„...én azt gondolom, ez inkább kollegiális kapcsolatnak kell, hogy legyen, az egy megtiszteltetés..." (belgyógyász, 49).

Ráadásul a telemedicinális ellátás során is vannak, akik a fentieknél szorosabb kapcsolatot teremtenek egymással. A távoli segítséget sok esetben egy „,belső klaszterből” kérik és adják, akikkel baráti és bizalmi viszonyt létesítenek:

„...tehát vannak határon belül, határon kivüli, de hát övelük mind személyesen, hogy is mondjam, a 90 \%-ával ... személyes kapcsolatot ápolok...” (radiológus, 42).

„,...akikhez még tudunk fordulni, külsö emberekhez, az sokkal inkább személyes kapcsolatrendszerek alapján fordulunk..." (radiológus, 37).

Ennek ellentéteként ugyanakkor egyes interjúalanyok arról is beszámolnak, miszerint telemedicinális kapcsolatban sokszor ismeretlen a másik fél - legyen az egy klinikus, vagy radiológus -, mindössze csak az ellátási kötelezettség teremt némi kontaktust közöttük:

„....más városból, messziröl dolgoznak be, azoknak szinte semmilyen kapcsolatuk nincsen sem a vizsgálatokat elvégzőkkel, sem a vizsgálatokat kérökkel...” (radiológus, 17).

„,... a legtöbben, akik igy telemedicinával foglalkoznak nem biztos, hogy ismerik azt, akivel netán a vonal, vagy az email túlvégén állnak...” (radiológus, 18).

Összességében elmondható, hogy a távgyógyászat jelentős hatást gyakorol mind a klasszikus orvos-beteg kapcsolatra, mind pedig az egészségügyi szakemberek közti kontaktusra.

Noha a nemzetközi szakirodalom szerint a telemedicina esetében az orvos-beteg közötti interperszonális távolság növekszik (CARTWRIGHT, L. 2000), a hazai empirikus tapasztalatok arra utalnak, hogy ez nem a távgyógyászat teljes spektrumában jelentkezik. A páciens és az orvos közti viszonyrendszer átalakulása ugyanis másként interpretálható a telemedicina egyes területein (BÁN A. 2017b).

GIDDENS strukturációs elmélete szerint a korábban bevett gyakorlat és rutin, más szóval a struktúra változik (GIDDENS, A. 1984). Ez úgy realizálódik, hogy az orvos-beteg viszony egyes esetekben tovább erősödik, más szituációkban viszont lényegében megszünik. 
A teleradiológiában lényegében semmilyen kapcsolatba nem kerül a beteg az orvossal, és noha ez a kontaktus egyébként is szük keresztmetszet e területen, ez teljesen személytelenné válik és kiüresedik, ami nem feltétlen tekinthető előnyösnek. Bizonyos esetekben szükségessé válhatnak objektív és szubjektív (klinikai) információk a páciensekről, amelyek nem mindig állnak rendelkezésre és ezek beszerzése sokszor problémát jelenthet, különösen külső intézményböl (BÁN A. 2017b).

$\mathrm{Az}$ egészségügyi paraméterek ( $\mathrm{pl}$. vérnyomás, vércukor stb.) távoli monitorozása a belgyógyászatban, kardiológiában, alapellátásban stb. noha a klasszikus orvos-beteg találkozók számát csökkenti, mégis egy minőségi változást generál e kapcsolatban. Ugyanis a távfelügyeletet általában személyes találkozó és egy, már kialakult bizalmi viszony előzi meg, ami csak tovább erősödik. Ez pedig hozzájárul a klasszikus orvos-beteg kapcsolatban néha jelentkező információs aszimmetria enyhüléséhez. A távfelügyelet a beteg biztonságérzetére, egészségkultúrájára és egészségi állapotára is jótékony hatást generál, miközben az orvos döntését is támogatja, hiszen jelentős egészségügyi adat áll rendelkezésre egy adott páciensröl (BÁN A. 2017b).

A hosszútávú bizalmi viszony sikeres fenntartásához és erősítéséhez - a cselekvőhálózat elméletnek megfelelően - is szükséges a hálózat emberi és nem emberi tényezőinek harmonikus együttmüködése (JóHANNESSON, G.T. - BAERENHOLDT, J.O. 2009). Ez magában foglalja az egészségügyi szakemberek és páciensek közötti kooperáción túl a távmonitorozáshoz szükséges müszaki-technikai feltételek és berendezések megfelelő müködését is.

A beteg-orvos viszony mellett az egészségügyi szakemberek közti kapcsolat is változik a telemedicinális ellátás során. E kontaktusokat többféleképpen jellemzik az interjúpartnerek. Ezek közé tartozhat a hierarchikus, a szakmai-kollegiális, a személyes és akár a kapcsolat „nélküli”. Tekintettel arra, hogy az egészségügyi ellátás hierarchikus, bizonyos elemek egyes helyzetekben feltehetően a távgyógyászatban is átöröklődnek. Ugyanakkor valószínüsíthetően a leggyakrabban kollegiális kapcsolat és szakmai kooperáció jellemzi a telemedicinális ellátást.

\subsection{A telemedicina egyéb szervezeti kérdései}

A telemedicina az orvos-beteg kapcsolat és két egészségügyi szakember közötti viszony átalakulásán felül egyéb szervezeti kérdéseket is érint. Ezen belül érdemes kiemelni, hogy miként módosul az orvosokat kiszolgáló egészségügyi szakszemélyzet (asszisztensek, technikusok, operátorok stb.) feladatköre és szerepe a telemedicinális ellátás - különös tekintettel a teleradiológia - során.

E témakörrel kapcsolatban felmerül hogyan jelennek meg a távgyógyászatban a magasan kvalifikált specialisták és milyen hatással vannak a telemedicinális ellátásra? Milyen szerepet töltenek be Magyarországon a legmagasabb progresszivitási szinten lévő egészségügyi intézmények (klinikák, országos intézetek) a távellátásban?

Az interjúpartnerek szerint az asszisztensek szerepe a klasszikus ellátásban sem elhanyagolható, de a telemedicinális ellátás során ez tovább növekszik. A távgyógyászat kulcsszereplőivé lépnek elő, hiszen sok esetben orvosokat váltanak ki a tevékenységük során, ami természetesen nem jelenti azt, hogy azok nem vesznek részt a gyógyítási folyamatban, csupán másra koncentrálnak. Így „...a távgyógyászat beépítésével a paramedikális személyzetnek a száma, aránya és súlya növekszik. Az orvosok száma csökken, a specialisták egyre többen vannak..." (szülész-nőgyógyász, 1).

A teleradiológia során a képzett asszisztencia készíti el a felvételt, amit aztán tovább küld egy radiológusnak, aki már csak a beteg leletével találkozik, és azt értékeli, illetve felállítja a 
diagnózist. Sok esetben a vizsgálat készítésének helyén nincs jelen orvos, így munkájuk során a maguk képzettségére, tapasztalatára számíthatnak:

„....adott esetben ... önállóan kell, hogy végezzenek vizsgálatokat, tehát nekik dönteni kell kvázi orvos helyett -, ezért van hangsúly a megfelelö beutalón...” (radiológus, 42).

„,... a radiológia jelentős részét egyedül, önállóan csinálják, hogy mit tesznek a teleradiológia alá, az egy nagyon fontos dolog..." (radiológus, 35).

Az asszisztensek tevékenysége azért is releváns, mert ők találkoznak a páciensekkel, nem pedig a leletező orvos. Így egyúttal szürői és birtokosai is a klinikai információknak, hiszen a beteggel való kapcsolattartás során számos, a kérő lapon nem feltétlen szereplö információhoz juthatnak, ami később nagy segítséget jelent a távoli radiológusnak a diagnózisnál.

Az asszisztencia támogatása nélkül ezekhez az információkhoz a távleletező csak a klinikus felkeresésével juthat, de ez sokszor vállalhatatlan, főleg ha a kolléga külső intézmény munkatársa. Az asszisztens „... tartja a kapcsolatot a felvételezéskor a beteggel, tehát ö tud anamnesztikus adatot fölvenni, ö tud esetleg fizikális kiegészitö megjegyzéseket tenni..." (radiológus, 3). A teleradiológia során az „...operátornak ... jóval komolyabb ... szakmai tudásának kell lennie ... hogy olyan módon reagáljon a betegre, hogy releváns információkat tudjon továbbadni nekem a beteggel kapcsolatban..." (radiológus, 37).

A távleletezésnél nem csupán a képalkotó berendezések minősége, a technikai személyzet tevékenysége, hanem annak szakmai felkészültsége is meghatározó. Tekintettel, hogy a kép minőségének diagnosztikai befolyásoló hatása van, az pedig nagyban múlik a készítő egészségügyi szakszemélyzet technikai képzettségétől, készségeitől, jártasságától, szintén felértékeli szerepüket:

„...én fogok-e tudni valamit mondani erröl a képröl, az azon múlik, hogy asszisztens olyan képet csinált-e róla..." (radiológus, 9).

„,...az, hogy az a vizsgálat milyen minöségben készül el, mikor készül el, ez mind-mind az asszisztencián múlik..." (radiológus, 18).

Az asszisztencia nem csupán a teleradiológiában, hanem általában a telemedicinában is támogatja és tehermentesíti az orvos munkáját. A technikai kérdésekben, a betegoktatásban, a távoli adatok előkészítésében stb. gyakorta részt vesznek. Ebből adódóan a megfelelö egészségügyi szakszemélyzet hiátusa egyfajta akadálya is lehet a telemedicina adaptálásának és a klinikai rutinban való alkalmazásának:

„.... a diabétesz edukátor tanitja be például a vércukor mérésére, a program használatára, tehát nem nekem kell ezzel törődni..." (szülész-nögyógyász, 39).

„,...ha nincs ott az orvos mellet az, aki meg tudja oldani a technikai kérdéseket, aki a fizikát, az elektronikát, az IT-t, akkor az orvos el fog veszni..." (neurológus, 30).

A telemedicinális ellátásban nem csupán az asszisztencia szerepe nő meg, hanem a magasan kvalifikált specialistáké is. Ez mindenekelőtt a nehezen diagnosztizálható, ritka kórképek felismerésében és más szakorvosok munkájának kontrollálásában mutatkozik meg. Az esetszám növekedésével párhuzamosan növekszik az implicit tudás (aminek birtokosai), ami a klasszikus ellátásban és a távellátásban egyaránt kamatoztatható:

„,...két funkciójuk van, egyrészt ... a másodleletezés, a másik meg az, hogy ezek a magasan kvalifikált embereket azért kellene teleradiológiai szolgáltatásba résztvevöként számon tartani ... úgy tudja magát szinten tartani..." (radiológus, 7).

„...fontos része volna a telemedicinának, hogy legyen elérhetö specialisták, és ezek nagyon fontos szerepet játszhatnak a különleges, nem mindennapi esetek diagnosztikájában..." (radiológus, 11).

Az infokommunikációs technológiák hatásának köszönhetően pedig a klinikai szakértelem, amely az expertekhez köthető, a távoli térségekbe és intézményekhez is eljut. Így az 
egészségügy területi egyenlőtlenségeinek mérséklésében, a minőségi ellátás hozzáférésének növelésében is meghatározó szerepet játszik:

„...egy nagyon felkészült szakember az ki tud szolgálni nagyon sok szatelit intézményt, vagy kórházat..." (szülész-nőgyógyász, 36).

„,...biztos, hogy az ottani aktivitásukból elvesz, és nagyon jó, hogy ad a kisebb településeknek is az ö tudásukból, csak hát nagyon kevesen vannak...” (radiológus, 13).

Ebben a tekintetben a specialisták elfoglaltsága, leterheltsége és ebből adódóan az elérhetősége jelent problémát. Ez pedig nehezíti az általuk kínált magas szintű egészségügyi szolgáltatás, tanácsadás igénybevételét egyes orvosok részéröl. Ugyanis „,..azok a szakorvosok, akik a telemedicinával, az expert oldalon állnak, azok leterheltsége nöni fog..." (idegsebész, 54). Ha a specialisták „,... elérhetőek, akkor ez mindenképpen segitség, csak kérdés, hogy milyen úton, módon lehet elérni öket..." (radiológus, 18).

Ráadásul a specialisták esetében az sem hagyható figyelmen kívül, hogy társadalmi státuszuk, kapcsolati hálójuk, intézményben elfoglalt (menedzseri) pozíciójukból adódóan jelentős hatást gyakorolhatnak - attitüdjüknek megfelelően - egyes telemedicinális szolgáltatások adaptálására, vagy ellenkezőleg, annak mellőzésére. Így „ez abszolút személyfüggö, a jelenlegi vezetőnk teljesen familiáris ezekben a dolgokban...” (belgyógyász, 40).

Az előzőeken felül a távgyógyászat szervezeti vonatkozásainak egyik eleme a legmagasabb progresszivitási szinten lévő, az egészségügyi ellátás csúcsintézményeinek szerepköre. Noha a nemzetközi szakirodalom szerint jelentős funkciót töltenek be az egészségügyi centrumok a telemedicinális hálózatok kialakulásában (STRÖMGEN, M. 2003), azonban a legtöbb interjúalany Magyarországon ezt nem érzékeli. Ugyanis az egységes informatikai rendszer hiányosságai meghatározó gátjai a telemedicinális hálózatnak.

„...ilyen országos hálózat létrehozása komoly eröforrást és erös szándékot igényel. De a klinikának nincs ilyen ..." (radiológus, 16).

„...nem nagyon tudok arról, hogy Magyarországon ma igazából központilag életre hívott telemedicinális rendszer lenne..." (dermatológus, 53).

Az interjúpartnerek többsége szerint a távgyógyászatban tehát hiányzik az egészségügyi intézmények hálózaton belüli kooperációja. Ezzel ellentétben általában egyéni próbálkozások és lokális léptékben történő telemedicinális szolgáltatások jellemzők. Ebben a tekintetben a klinikák és országos intézmények szerepe szórványos és eseti jellegü:

„...szerintem a telemedicina olyan elszigetelt kis csoportokban müködik, semmi hálózati jellege nincs ... nem látok olyan különleges szerepüket...” (radiológus, 11).

„...vannak lokális kezdeményezések, egy-egy valaki próbál lépni, de nincsen semmi, nem látunk egymásra rá, nem tudunk eszerint kommunikálni..." (belgyógyász, 63).

Az előzőekkel ellentétben azonban megjelenik egy olyan álláspont is, miszerint a magas progresszivitási szinteken lévő intézmények a kutatási és fejlesztési tevékenységeken keresztül kapcsolódnak be a távgyógyászatba, de ezek sok esetben még „take off” fázisban lévő projektek, melyeknek a hatásai jelenleg még nem érzékelhetők. Ugyanakkor egyes álláspontok szerint ezek az intézmények nélkül nem képzelhető el érdemi telemedicinális ellátás a jövőben:

„Ez az egész rendszer most van kialakulóban, másképpen ez nem képzelhetö el ... egy regionális feladatot ellátó tercier központnak vezetö szerepet kell játszania a telemedicinának..." (szülész-nőgyógyász, 36).

„,...az a kevés távellátás, ami van, az csúcsintézményekben csoportosul. Nagyon egyszerüen azért, mert egy jelentös része ezeknek az ellátásoknak azért még kutatási fázisban van, és a kutatás az egyetemekhez kötött..." (neurológus, 30). 
Ráadásul vannak olyan szív- és érrendszeri megbetegedések, ahol telemedicinális úton (lásd transztelefonikus $\mathrm{EKG}$ ) készült és továbbított jelek értékelésében az egészségügyi csúcsintézmények már meghatározó szerepet töltenek be. Ezáltal képesek redukálni a szükséges betegutat, így pedig a páciens gyorsan, szakszerü ellátásban részesül, ami sok esetben életmentő, ugyanis „,...az akut betegek befogadásánál, a gyors döntéstámogatásánál az infarktusos betegnek, ez általában kialakult rá a rendszer, hogy a telemedicinális információ az elébe mehessen a beteg fizikális megérkezésének, és támogassa a döntést..." (kardiológus, 24). Jelenleg már rutinszerüen müködik, hogy „,...az EKG-kat telemedicinával lehet belövöldözni a szívkatéteres laborba is ... söt még a mentöszolgálat is ... be tudja..." (belgyógyász, 50).

A fentiekben felvázolt szervezeti kérdések általános konklúziója, hogy a személyi tényezők a telemedicinális ellátásban is releváns szerepet kapnak. Az egészségügyi asszisztensek, technikusok kulcsszereplöi a távellátásnak. Ennek oka a teleradiológiában, hogy a vizsgálatot sok esetben maguk végzik, és a leletek minőségének diagnosztikai befolyásoló hatása van, ezért felértékelődik a szakértelmük, felkészültségük.

Ráadásul ők hordozzák a klinikai információkat a betegekről, hiszen a páciensek velük, és nem a radiológusokkal találkoznak. Ez lényegében megerősíti a nemzetközi szakirodalomban is foglaltakat, miszerint az orvos fizikai jelenlétének hiányában kialakul egyfajta függőség az asszisztenciától (MORT, M. - MAY, C. R. - Williams, T. 2003). A távfelügyelet tekintetében is jelentős terhet vesznek le az orvosokról, mivel a betegoktatásban, a telemedicinális adatok elökészítésében, esetleg értékelésében is részt vesznek.

GIDDENS strukturációs elmélete szerint értékelve elmondható, hogy a telemedicinális ellátás során az egészségügyi szakszemélyzet szerepe, feladata stb. tekintetében módosulnak a korábban bevett gyakorlatok, struktúrák (GIDDENS, A. 1984).

A kisegítő szakszemélyzet mellett az expertek szerepe szintén megkérdőjelezhetetlen. Ez elsősorban a speciális esetek diagnosztizálásában, illetve a szaktudás távoli térségekbe való eljutásában nyilvánul meg. Ugyanakkor az sem hagyható figyelmen kívül, hogy az elérhetőségük sokszor problematikus.

$\mathrm{Az}$ egészségügyi csúcsintézmények alapvetően jelenleg még nem szerves részei a telemedicinális hálózatnak és ellátásnak, csak esetlegesen és egyes akut megbetegedéseknél. Ugyanakkor egyre több fejlesztési projektben vesznek részt, ami pozitív irányt mutat a jövőt illetően. Jelenleg nagyobb szerepet kapnak a szórványosan megjelenő, lokális telemedicinális szolgáltatások.

\subsection{Az e-egészségügyi szolgáltatások és a távoli egészségügyi közösségek}

\subsubsection{A telemedicina esetleges hatásai a távoli egészségügyi közösségekre egy egészségportál példáján keresztül}

A tágabban értelmezett telemedicina (vagy e-egészségügyi szolgáltatás) internetes egészségügyi közösségekre gyakorolt hatásai többek között tartalomelemzéssel és félig strukturált interjúk segítségével is vizsgálhatók. A módszertani fejezetben külön kiemeltem a tartalomelemzést, melynek során egy hazai egészségportál orvos válaszol rovatának tíz legtöbb kérdést tartalmazó témaköréből 2500 feletti szakértői választ elemeztem.

A tíz téma közül a legtágabb csoportot a nőgyógyászati kérdések és válaszok jelentik. Ebben a tekintetben összesen 10.908 kérdésből 545-öt vizsgáltam. Az eredmények azt mutatják, hogy az esetek közel háromnegyedében a szakértői válaszokban előtérbe kerül az egészségügyi intézményhez, illetve orvoshoz fordulás szükségessége (amiben elenyésző szerepet játszik a vényköteles gyógyszerek), míg terápiás tanács csupán a válaszok alig több 
mint ötödében jelentkezik. Ez utóbbiak többsége azonban az ellátás igénybevételével együttesen $(16,88 \%)$ fordul elö.

A bemutatott értékek önmagukban is azt sejtetik, hogy a nőgyógyászati betegségek esetén ez a fajta internetes e-egészségügyi szolgáltatás kevésbé tehermentesíti az egészségügyi ellátórendszert és az ellátásban résztvevő szakorvosokat. Ráadásul a válaszoknak több mint a felében csupán az orvoshoz fordulás jelenik meg, míg ennek ellenpontjaként, ahol kizárólag terápiás tanácsot adnak az egészségügyi szakemberek (orvoshoz fordulás viszont nem kerül elő), az elenyészőnek (4,04 \%) mondható.

Viszonylag magas e betegségcsoportnál azoknak a szituációknak az aránya, ahol sem az egészségügyi ellátás esetleges igénybevételével, sem pedig konkrét érdemi tanáccsal nem lehet számolni. Az esetek több mint ötödében ugyanis nem alkalmazható az előző két objektív mérőszám, ami igen magasnak mondható. Ezen belül nagyobb részt $(17,80 \%)$ egy érdeklődő kérdésre kap választ a páciens, amely esetekben viszont vélhetően lezártnak tekinthető az adott betegút. Míg kisebb részt (3,30 \%) vagy semmilyen visszajelzés nem érkezik a kérdésre, vagy adat hiányában meghiúsul a válaszadás, és ekkor a válaszadó újabb információkat kér a betegtől (ami újabb kérdés-választ generálhat).

A második legnagyobb csoportot a mozgásszervi betegségek jelentik 6.580 kérdéssel, amiből 329-et választottam ki. Itt már az esetek majdnem négyötödében jelentkezik az ellátás igénybevételének szükségessége, és jóval meghatározóbb a terápiás tanácsok aránya is, ami megközelíti a szituációk közel felét. A kezelési javaslatok és az orvoshoz fordulás is gyakran együtt (41,64\%) jelentkezik, ami a legnagyobb értéket jelöli a többi betegségcsoporthoz viszonyítva.

A mozgásszervi betegségeknél sem hagyható figyelmen kívül a fizikai jelenléten alapuló ellátás szerepe, azonban azt kiegészítve számos internetes egészségügyi tanács is segítheti a páciensek egészségi állapotának javítását, regenerálódását (pl. porcerősítők ajánlása).

A kizárólagosan csak orvosi ellátás szükségességére a válaszok több mint harmadánál, míg a csupán egészségügyi tanáccsal a szituációk alig néhány százalékánál $(6,38 \%)$ lehet számolni. Ahol a fenti két mérőszám nem alkalmazható, az esetek többségénél a betegek érdeklődésének a válaszadók eleget tesznek (10,33\%), amelyen belül általában feltételezhető a betegút lezárása, míg előfordulnak olyan helyzetek is, ahol ezt az igényüket nem elégítik ki $(3,95 \%)$.

A következő nagyságrendi kategória, a bőrgyógyászati betegségek, a mozgásszervihez hasonló értékekkel rendelkeznek. E témakörhöz tartozó 6.297 kérdésből 315-öt vizsgáltam. A válaszok majdnem háromnegyedénél jelenik meg az orvoshoz fordulás nélkülözhetetlensége. A teljes esetszám több mint 10 százalékánál pedig csak a vényköteles gyógyszerek ajánlásából lehet következtetni az egészségügyi ellátás igénybevételének szükségességére, és ez az érték az összes betegségcsoportnál itt a legmagasabb.

Ezek mellett igen meghatározó a különféle kezelési tanácsok aránya is, ami a válaszok közel felénél jelentkezik. Ide sorolható a különböző bőrbetegségekre kapható kenőcsök, vitaminok, a különféle javaslatok és számos egyéb (gyógyhatású) készítmények, amelyekkel kapcsolatos információk megosztására vélhetően az internetes e-egészségügyi platform kiválóan alkalmasnak bizonyul.

A terápiás tanácsok és az orvoshoz fordulás együttesen az esetek közel harmadánál figyelhetők meg, ami szintén magasnak mondható a többi vizsgált csoporthoz képest. A válaszok közel 40 százalékánál csak az ellátás igénybevételével, míg több mint 15 százalékánál csak kezelési javaslattal lehet számolni. Az esetek több mint tizedénél pedig nem jelenik meg az orvoshoz fordulás szükségessége és terápiás tanácsban sem részesül a páciens, ugyanakkor ezek többségénél (10,48 \%) legalább parciálisan kielégítő választ kap. 
A következő csoportnál, az emésztőrendszeri megbetegedéseknél 5.816 kérdésből 291-et választottam ki. A többi betegségcsoporthoz képest ebben a tekintetben a legalacsonyabb az orvoshoz fordulás szükségessége, de így is megközelíti az esetek kétharmadát.

Ráadásul a bőr- és a nőgyógyászati betegségek mellett szintén említésre méltó a vényköteles gyógyszerekből következtetett egészségügyi ellátás igénybevételének szükségessége $(4,81 \%)$. Ezzel ellentétben a terápiás tanácsok - ami a legmagasabb értékkel bír a többi betegségcsoporthoz viszonyítva - a válaszok közel felében előfordulnak, melyek között mindenekelőtt az egészséges életmóddal kapcsolatos javaslatok (pl. megfelelő folyadékbevitel, rendszeres mozgás, rostban gazdag ételek, többszöri kis étkezések, alacsony szénhidrát bevitel stb.) szerepelnek.

A többi betegségcsoporthoz viszonyítva itt a legnagyobb arányban mutatkozik meg a csak terápiás tanácsok $(17,87 \%$ ), míg az esetek több mint harmadánál csupán az orvoshoz fordulás szükségessége a mérvadó. Míg a kettő együttesen a válaszok 30 százalékánál jelentkezik.

Azokban a szituációkban, amikor a fenti objektív mérőszámok nem alkalmazhatók, ott többségében e betegségcsoportnál is választ kaphatnak $(12,37 \%)$ a betegek a kérdéseikre, de egyes esetekben ennek az ellenkezője is megjelenik (4,47\%).

Az emésztőrendszeri betegségeket nagyságrendileg az ún. „egyéb” kategória követi a maga 5.751 kérdésével, amiből 288-at vizsgáltam. Ide számos betegség tartozik: emésztörendszeri, nőgyógyászati, szív- és érrendszeri, endokrin stb., ezért „,vegyes” típusnak tekinthető. Ennek előnye, hogy lehetőséget ad annak elemzésére, hogy mennyiben változnak az objektív mérőszámok megoszlási értékei a homogén csoportokhoz viszonyítva.

Az esetek közel háromnegyedénél előtérbe kerül az orvoshoz fordulás, ami a bőrbetegségekhez hasonló értéket mutat, míg a terápiás tanácsok megoszlása az összes válasz negyedénél jelentkezik. Az egészségügyi ellátás kizárólagos nélkülözhetetlensége a szituációknak több mint a felénél fordul elő, addig a csupán kezelési javaslat részaránya $(7,64$ $\%)$ elenyésző. A két kategória együttes megjelenésének értéke $(17,36 \%)$ is alacsonynak mondható. Ezzel ellentétben, amikor egyik indikátorral sem lehet számolni (21,18 \%), igen meghatározó a homogén betegségkategóriákhoz viszonyítva.

Összességében tehát az „egyéb” betegségcsoport jelentős eltérést nem mutat a többi típushoz viszonyítva, csupán annyiban, hogy magasabb azoknak az eseteknek az aránya, ahol a páciens vagy kap érdemi választ $(15,97 \%)$, vagy nem $(5,21 \%)$, de ezek a kérdések nem hozhatók kapcsolatba sem a kezelési javaslattal, sem pedig a klasszikus ellátás szükségességével.

A neurológiai kórképek tekintetében 3.957 kérdés közül 198-at választottam ki. E csoport egyedisége, hogy a többi kategóriához viszonyítva itt a legmagasabb az orvoshoz fordulás aránya $(82,83 \%)$, ami egyrészt betudható az esetleges kórkép súlyosságának, továbbá e betegségtípus kezelésének, ami általában kizárja az egészségügyi ellátórendszer megkerülését és az önmagában alkalmazott otthoni, „öngyógyítás” lehetőségét.

Az előzővel ellentétben a terápiás tanácsok az esetek harmadánál sem fordulnak elö. Ráadásul a válaszoknak több mint a felében csupán az egészségügyi ellátás szükségessége mutatkozik meg, míg a kizárólagos kezelési javaslatok megjelenésének aránya $(4,04 \%)$ a nőgyógyászati betegségekhez hasonlóan csekély. A szituációknak valamivel több mint a negyedében az orvoshoz fordulás és a terápiás javaslat együttesen jelentkezik, míg több mint tizedében egyik sem. Ez utóbbi esetben többségében $(11,11 \%)$ válasz is érkezik a páciensek kérdéseire.

Az urológiai betegségeket érintő csoport esetében 3.826 kérdésből 191-et vizsgáltam. Az orvoshoz fordulás gyakorisága igen magasnak mondható $(76,44 \%)$, míg a terápiás javaslat megjelenése a többi típushoz viszonyítva a legalacsonyabb értékek között szerepel $(15,71 \%)$. Ráadásul a két indikátor együttesen az esetek alig több mint 10 százalékában fordul elő. 
A válaszok közel kétharmadában csupán az orvoshoz fordulás jelenik meg, ami legkiemelkedőbb érték az összes betegségtípus között. Ezzel ellentétben a kezelési javaslat önmagában az esetek kis százalékában (5,24 \%) jelenik meg.

Tekintettel a fenti értékekre az látszik igazolódni, hogy az urológiai betegségeknél kevésbé alkalmazhatók az internetes egészségügyi szolgáltatások adta lehetőségek. A válaszok közel ötödében sem az orvoshoz fordulással, sem pedig a terápiás javaslattal nem lehet számolni, ezek többségében $(15,71 \%)$ azonban érdemi választ kaphat a páciens a kérdésére.

Az urológiai betegségek után a szív- és érrendszeri megbetegedések alkotják a következő kategóriát, ahol 2.914 kérdésből 146-ot választottam ki. E csoportnál a második legmagasabb az orvoshoz fordulás gyakorisága a többi betegséghez viszonyítva, ami meghaladja az esetek négyötödét. Ugyanakkor a terápiás tanácsok sem mondhatók alacsonynak, hiszen a válaszok közel 30 százalékában előfordulnak.

Ebben a tekintetben is - akár az emésztőrendszeri betegségeknél - számolni kell az egészséges életmóddal kapcsolatos javaslatokkal (pl. rendszeres testmozgás, káros szenvedélyek feladása stb.).

Önmagában az egészségügyi ellátás szükségessége a válaszok több mint felében, míg a csupán terápiás tanácsok az esetek kevesebb, mint 5 százalékában szerepelnek. A két indikátor együttesen a szituációk közel negyedében jelentkezik. Míg az esetek 15 százalékában ezek nem alkalmazhatók, amelyek zömében $(13,01 \%)$ releváns választ várhatnak a betegek.

$\mathrm{Az}$ endokrin kórképeknél 2.632 kérdésböl mindösszesen 132-öt vizsgáltam. Az egészségügyi ellátás igénybevételének szükségessége az esetek közel háromnegyedénél jelentkezik, míg a terápiás javaslatok előfordulása a többi betegcsoporthoz viszonyítva a legalacsonyabb érteket mutatja (12,12\%).

Ezeknél a kórképeknél általában nélkülözhetetlen a fizikai jelenléten alapuló ellátás és a laborvizsgálatok, amit az e-egészségügy nem bír pótolni. A csupán orvoshoz fordulás indikátora a legmagasabb arányok között szerepel és megközelíti az esetek kétharmadát, ezzel ellentétben önmagában a kezelési javaslatok megjelenése a legjelentéktelenebb az összes betegségtípushoz viszonyítva (3,03\%).

Az orvoshoz fordulás és a terápiás tanácsok együttes előfordulása az előzőekből adódóan a 10 százalékot sem éri el. Ennek ellenére a válaszok negyedénél - ami szintén a legmagasabb érték - egyik objektív indikátorral sem lehet számolni. Ebben a tekintetben igen jelentős a páciensek kérdésére adott érdemi válaszok aránya (18,94\%).

Az utolsó betegségcsoportot a fül-orr-gégészeti kórképek jelentik, ahol 2.621 kérdésből 131-et választottam ki. Mind az ellátórendszer szolgáltatásainak igénybevétele, mind pedig a terápiás tanácsok előfordulása meghatározó. Az előbbi, az esetek közel négyötödénél, míg az utóbbi a válaszok több mint 40 százalékánál jelentkezik.

A csak kezelési javaslatok megoszlása (14,50 \%) szintén a legmagasabb értékek között szerepel. Ezekben a szituációkban különböző vény nélkül is kapható nyákoldókkal, inhalátorokkal stb. lehet számolni. Ugyanakkor önmagában az orvoshoz fordulás gyakorisága is meghaladja az esetek felét. Az objektív indikátorok együttesen a válaszok negyedénél fordulnak elö, míg azon esetek aránya, ahol ezek nem alkalmazhatók meglehetősen csekélynek $(6,87 \%)$ mondható.

Összességében tehát az 51.302 kérdésből 2.566-ot elemeztem. Az orvoshoz fordulás az esetek háromnegyedénél, míg a terápiás javaslatok a válaszok kevesebb mint a harmadában jelentkeznek (lásd Melléklet 7.).

Az egészségügyi ellátás kizárólagos szükségessége a szituációk felét érinti, ugyanakkor a csak kezelési javaslat előfordulása nem haladja meg a 10 százalékot. Az orvoshoz fordulás és a terápiás tanács együttesen a válaszok közel negyedében mutatkozik meg. 
Azokban az esetekben, ahol a fenti mérőszámok nem használhatók $(17,11 \%)$, ott szintén zömében (13,68\%) az egészségügyi szakemberek egyszerüen választ adnak a páciensek tájékozódó kérdéseire.

Mind az egyes betegségtípusok, mind pedig az összesített értékelés eredményei azt mutatják, hogy az e-egészségügyi platform mérsékelten redukálja az egészségügyi ellátórendszer betegforgalmát és a szakemberek leterheltségét, bár kétségtelenül szerepe nem hagyható figyelmen kívül.

Az előbbit nem csupán az orvoshoz fordulás szükségességének magas aránya interpretálja, hanem az is, hogy az orvosok a terápiás javaslatot önmagában (klasszikus ellátás nélkül) igen csekély mértékben tartják elegendőnek az egyes válaszoknál. Ráadásul a csupán kezelési javaslatok sem jelentenek teljes garanciát a betegút lezárására, hiszen a pontos diagnózis felállítása általában fizikai vizsgálatot igényel, ebből adódóan kérdéses, hogy az adott egészségportálos javaslat milyen mértékben hasznosul.

A betegút lezárása feltehetően azokban az esetekben van nagyobb esély, ahol sem az orvoshoz fordulás szükségessége nem merül fel, sem pedig terápiás tanácsadás nem történik, kvázi egyszerüen felvilágosítják, illetve tájékoztatják a válaszadók az érdeklődő pácienseket, így azok valószínűsíthetően kisebb gyakorisággal keresik fel az egészségügyi ellátót az adott kérdésben. Ebben a tekintetben óriási jelentőséggel bírnak az egészségportálok, hiszen hozzájárulnak a felesleges betegforgalom redukálásához.

Továbbá meghatározó szerepet kapnak a terápiás javaslatok, különösen egyes betegségcsoportoknál (pl. emésztőrendszeri és mozgásszervi megbetegedések, bőrbetegségek stb.). Egyrészt vannak bizonyos kórképek, ahol az egészséges életmód (és annak terjesztése) a legjobb kezelési módszerként funkcionál, ami által a spontán gyógyulás esélye megnő. Másrészt az előzőekhez kapcsolódóan kevésbé súlyos betegségeknél egyes gyógyhatású készítmények (vény nélküli gyógyszerek) elősegítik a regenerálódást az ellátórendszer szolgáltatásainak igénybevétele nélkül is.

Ugyanakkor igen gyakoriak azok a helyzetek is, amikor a magasabb progresszivitású ellátás mellett az alternatív gyógyászati lehetőségek szerepe is meghatározóvá válik. Összességében tehát jelentős egészség-nyereséggel járhat a páciensek szempontjából az eegészségügyi szolgáltatások használata, azokban az esetekben is, amikor a betegforgalmat nem csökkenti. A prevenció szerepéröl nem is beszélve, aminek jótékony hatásait igen nehéz megbecsülni, hiszen azok hosszútávon jelentkeznek.

Az eddigiek alapján kirajzolódik, hogy a válaszokat alapvetően determinálja a feltett kérdés jellege, amelyek típusai indukálnak egy adott reakciót (pl. bizonyos életveszélyes helyzetekben nem adható más tanács, mintsem, hogy a páciens sürgősen keresse fel az orvosát).

A kérdésekre adott válaszok sok esetben személyiségfüggők. Egyes egészségügyi szakemberek kevésbé preferálják az internetes távgyógyászatot, így nagyobb gyakorisággal fordulnak elő a válaszaikban, hogy a személyes megjelenésen alapuló ellátás semmi esetre sem kerülhető el. Ennek ellenpéldájaként egyes orvosok nagy tapasztalattal rendelkeznek némely alternatív gyógyászati lehetőséggel kapcsolatosan, így azokat teljes biztonsággal ajánlják önmagukban, vagy az orvosi ellátás kiegészítéseként.

A szakmai precizitás, a kompetencia kérdése egy további lényeges aspektus, ami befolyásolhatja a válaszokat és a terápia eredményességét.

A téma másik vonatkozása a betegút lezárásának kérdése. A szakértői válaszokból csak következtetni lehet arra, hogy a páciens kielégítőnek tartja-e azt, illetve ami ennél is fontosabb, hogy az egészségi állapotában hoz-e vajon javulást, hiszen ezek kontrollálására nincs lehetőség. 
Az sem hagyható figyelmen kívül, hogy a beteg hogyan éli meg az adott diskurzust, mi az, ami számára releváns. Itt nem csak a konkrét egészség-nyereséggel kell számolni, hanem a spirituális aspektusokkal, vagyis ha a pácienst megnyugtatja a válasz, már önmagában értéket képvisel.

Összességében egy adott egészségportál orvos válaszol rovatának, illetve annak kérdéseinek a tartalomelemzése egy komplex szemléletet igényel, ahol az eredményesség definiálása és kvantifikálása meglehetősen bonyolult.

\subsubsection{A telemedicina távoli egészségügyi közösségekre gyakorolt hatásai az interjúpartnerek álláspontja alapján}

A tartalomelemzés végkimenetele bizonyos tekintetben hasonlóságot, más esetekben azonban különbséget is mutat az interjúk során kapott eredményhez képest. Ebből adódóan célszerü ezeket megvizsgálni a félig strukturált interjúk vonatkozásából is.

Az alap- és szakellátásban dolgozó interjúpartnerek túlnyomó többsége, mintegy négyötöde egyetlen egészségportál regisztrált felhasználója közé sem tartozik, ami egyrészt azt tükrözi, hogy túlságosan nem preferálják az internetes egészségügyi tanácsadást és az ezzel kapcsolatos szolgáltatásokat, másrészt szükös időbeosztásuk nem teszi lehetővé a távoli páciensek kérdéseire való válaszadást. Az egészségportálokra regisztrált interjúalanyok közül is (kb. $20 \%$ többen már nem használják ezeket a szolgáltatásokat, mindenekelőtt a fenti okok miatt.

Ami még inkább szembetünő, hogy az orvos interjúpartnereknek csupán egyharmada tekinti telemedicinának a webes egészség-tanácsadásokat, és közülük is többen bizonytalanok a terminológiát illetően, vagyis általában csak a tágabban értelmezett telemedicina tárgykörébe sorolják be ezeket a szolgáltatásokat. Ugyanakkor utalnak arra, hogy ezek jellege alapvetően eltér attól, ami a „gyakorlati” telemedicinát jellemzi:

„....kihez fordulhat, akkor mit jelent a problémája ... azt gondolom, hogy ez hozzávehetö a telemedicinához..." (patológus, 38).

„,...mondhatjuk, hogy ez is valamilyen szinten belegyömöszölhetö a távmedicinába, de más a cél, más az eszközrendszer ... az alapvetö információink hiányoznak a betegröl..." (idegsebész, 25).

Az interjúpartnerek többsége azonban részben a fentiekből adódóan másként tekint ezekre az internetes tartalmakra. Meglátásuk szerint ezek egyfajta egészséggel kapcsolatos tanácsadó szolgáltatásként értelmezhetők, amelyek noha rendelkeznek pozitív externáliákkal, nem tekinthetők a távgyógyászat szerves részének. Így „...ezek gyakorlatilag ismeretterjesztő fórumok, amiknek rengeteg hasznuk lenne, ha nem úgy vennék a betegek...” (radiológus, 17). Egy másik interjúalany szerint „,...ez egy egészségnevelés, vagy információ, informálás. Nem hinném ezt telemedicinának..." (háziorvos, 31 ).

Az interjúpartnerek általában lényegre törően reflektálnak erre a témára. Az interjúalanyok közel harmada részletesen kifejti álláspontját a kérdésről, amihez több esetben negatív érzelmi töltés párosul.

Ennek ellenére azonban az interjúpartnerek az egészségportálok előnyeire és hátrányaira egyaránt fókuszálnak, kitérnek annak negatív és pozitív aspektusaira is. Az egyik legnagyobb hiányosságot az interneten fellelhető egészségügyi tanácsoknál, azok hitelességében és validitásában találják, ugyanis - álláspontjuk szerint - ezek nem minden esetben helytállók, mivel „,... a neten nagyon sokféle, fals információ van ... ezeknek a terjedését javithatja az, ha autentikus helyröl jön az információ..." (háziorvos, 44). 
A problémát tovább mélyíti, hogy egyesek szerint néhány esetben olyanok nyújtanak egészségügyi tanácsadást a pácienseknek, akik teljesen inkompetensek a kérdésben, vagy nincs az adott területen szakvizsgájuk, így az könnyen tévútra viheti a betegeket:

„,...akármilyen képzettnek tartó emberek válaszolnak, nagyon, nagyon sok hülyeség van rajta, és veszélyes dolgok, veszélyes dolgok...” (radiológus, 10).

Természetesen ez nem jelenti azt, hogy mindegyik internetes portálnál jelentkeznek a fenti hiányosságok, de ezek álláspontjuk szerint releváns problémát jelentenek. Ebből adódóan szükséges lenne ezeket az információkat kontrollálni és a jövőben minimalizálni a nem hitelesen müködő portálok müködését, hiszen azok ártalmasak is lehetnek a páciensek egészségi állapotára, mert „,... annyi energia lenne mindegyiket átnézni, hogy talán ezek, amik relativ hitelesebbek, de sok van, amelyik azért nem hiteles..." (háziorvos, 34). Egy másik háziorvos úgy ítéli meg, hogy „...nem müködnek igazán jól, és szerintem itt is a legnagyobb baj, hogy nincs kontrollálva..." (radiológus, 47).

A fentiekhez kapcsolódóan ezek az internetes egészségügyi szolgáltatások sok esetben plusz terhet raknak az ellátórendszerre, ami nem feltétlen indokolt:

„....nagyon sok felesleges vizsgálatot generál, én úgy gondolom, mert ugye ... alapvetöen rosszul müködik..." (radiológus, 4).

„...egy-két felesleges szakorvosi vizsgálatot ki lehet hagyni, ugyanakkor meg mások szükségtelen szakorvosi vizsgálatokat fognak generálni...” (sebész, 14).

$\mathrm{Az}$ ellátás igénybevételének növekedését sokszor a pánikbetegek gyakori előfordulása indukálja, továbbá ezek a páciensek sokszor „túlképzettek” a betegségüket illetően, ami nem csupán az orvos tekintélyét ássa alá, hanem további problémákat is generálhat.

Elégedetlenné válhatnak a páciensek a kezelőorvosukkal és több esetben a bizalmat is elveszíthetik, ami végtére is az orvos-beteg kapcsolat alapja, és ami hosszú távon az egészségi állapotra is kedvezőtlen hatást gyakorolhat:

„....számos képzett beteg is megjelenik, aki kiolvasta ezeken a közösségi portálokon, vagy bárhonnan a betegségtünetet és akkor szeretné, ha mi meg is állapítanánk." (belgyógyász, $63)$.

„....utánanéz az interneten ... egy olyan téves információhoz jut, hogy vagy nem kapja meg a megfelelö ellátást, vagy már az elsö alkalommal bizalmát veszti az orvoshoz, mert már mást mond, mint ami az interneten volt leírva..." (radiológus, 13).

Több interjúpartner is tehát amellett foglal állást, hogy az internetes egészségportálok nem redukálják az egészségügyi ellátórendszer terheit és az orvosok leterheltségét, vagyis az egészséghasznuk meglehetősen csekély, hiszen a gyógyításhoz továbbra is szükséges a kezelőorvos felkeresése, tehát a páciensek egészségügyi problémájára ezek a szolgáltatások nem jelentenek végső megoldást, mivel a „... kérdésnek az a válasza, hogy keresse meg az orvosát. Ez a végeredmény, tehát nem fogja csökkenteni..." (radiológus, 20). Éppen ezért „,csinálnék belöle szivesen egy statisztikát, hogy ezeknek a véleményeknek hány százalékán van ... a végén ott, hogy keresse fel doktorát..." (neurológus, 30).

Ezt erősítik azok a webes felhívások is, amelyek figyelmeztetnek, hogy nem vállalják a felelősséget a fizikai orvos-beteg találkozás kimaradásából fakadó esetlegesen bekövetkező egészségkárosodásért:

„....a beteg elektronikus úton egy orvostól kér általánosságban tanácsot, mert azért ha megnézi, ... ezekre nagyon figyelnek ... minden tanácsuk végén, vagy az oldalon több helyen szerepel, hogy ök ezért felelösséget nem vállalnak..." (idegsebész, 27).

Egy másfajta kérdést vet fel az egészségportálokon válaszadó orvosok felelőssége. Ebben a tekintetben több interjúpartner is kifogást emel, hiszen hiányzó adatokra konkrét diagnózist, de akár terápiás javaslatot is adni dezinformációhoz vezethet: 
„,...kollégák az interneten válaszolnak-e, én ezt egy elég kockázatos dolognak találom, vajon mindig elég konkrét-e a kérdés? Vajon mindig elég körültekintö-e a válasz?...” (radiológus, 16).

„,...egyszerüen felelötlenség arra válaszolni. Nincsen az orvos tisztában konkrét panasszal, az anamnézissel, leletekkel, vizsgálattal..." (háziorvos, 57).

Ráadásul egyes interjúpartnerek szerint az információ, amit a beteg a távoli orvostól kap nemcsak megnyugvást nyújthat, hanem azzal ellenkező hatást kiváltva növelheti a szorongást, ami nem feltétlen megalapozott és meghosszabbíthatja a betegutat, mivel a páciens később kerülhet az egészségügyi ellátórendszer látókörébe. Problémát jelent „...ha a betegnek nagy baja van és meg nyugtatjuk, akkor esetleg nem derül ki, ha a betegnek pedig kis baja van, akkor meg felkelthetjük benne..." (neurológus, 23). Egy másik neurológus a következőképpen nyilatkozik: „...felesleges idötöltésnek gondolom, és ráadásul generálom a betegben a betegségtudatot, és egy csomó olyan információhoz jut hozzá, ami veszélyes információ...” (neurológus, 30).

Egyébként is az orvoslás egy meghatározó momentuma a fizikai találkozás, ami bizonyos szituációkban nem váltható ki. A pontos diagnózis felállításához és a megfelelő kezeléshez elengedhetetlen.

Ehhez kapcsolódva problémát jelent az egészségportálokon a párbeszédek kialakulása, mivel nem azonnal kap választ a páciens a kérdéseire (vagy éppen a válaszadó egészségügyi szakember mikor visszakérdez), pedig a gyors reflektálás alapvetően determinálhatja a diskurzus kimenetelét és a kapott tanácsokat:

„...azért az orvos-beteg viszonyban a személyesség bizonyos területen, van ahol nélkülözhetetlen ..." (radiológus, 35).

„...vvalaki feltesz bizonyos kérdést, személytelen. Tehát hogyha személyesen beszélünk, azonnal vissza tudok kérdezni..." (kardiológus, 29).

$\mathrm{Az}$ interjúpartnerek szerint azonban az internetes egészségportálok nem csupán negatív, hanem pozitív hatásokkal is rendelkeznek. Az informáltságnak és a „tudálékosságnak” is megvan a maga szerepe, hiszen az ellátásban elöremutató lehet:

„....ugyanakkor jár egy csomó pozitív hatással, tehát hogy számtalan olyan beteget láttam, meglepöen felkészült tud lenni ... okos kérdései vannak...” (radiológus, 35).

Azért is lényeges a beteg megfelelö informáltsága, mert hozzájárulhat a compliance növekedéséhez, ami a gyorsabb gyógyulást, illetve az egészségi állapot javulását eredményezheti, mivel „...szakmai, gyakorlati információkhoz jutnak, az én munkámat nagymértékben segíti az, hogy megerösitést kapnak abban, amit hallottak..." (háziorvos, 62). Az előzőeket megerösíti az is, hogy „,...egy tudatos beteg, aki meg akarja érteni, hogy mi történik vele ... sokkal jobban be fogja tartani a terápiás utasitásokat, oda fog figyelni a dolgokra..." (radiológus, 42).

Továbbá az sem hagyható figyelmen kívül, hogy a fizikai orvos-beteg találkozó során felmerült egészségügyi tanácsok jelentős része nem hasznosul, mivel a frusztráltság, a félelem több esetben egyfajta barrierként jelenik meg és feledésbe merül az orvosi információ. Ezzel ellentétben, amikor a beteg az interneten keresztül osztja meg a kérdéseit, akkor ezek a kötöttségek alól „felszabadul”:

„...egy beteg közvetlen beszél egy orvossal, akkor egyébként körülbelül az információnak a fele sem jut el hozzá igazából..." (radiológus, 9).

A fentiekhez kapcsolódva egyik legfontosabb hozadék tehát, hogy ezek a távoli egészségügyi tanácsok növelik a páciensek egészségkultúrájának szintjét, betegségfelismerő képességét, ami nem csupán a hipochonder betegek számát generálja, hanem direkt, vagy indirekt hozzájárulhat a gyorsabb diagnózishoz és ellátáshoz, mivel nagyobb valószínüséggel kerülnek az ellátórendszer látókörébe. 
Ráadásul a tudatos és egészséges életmódra való törekvés - a távoli terápiás javaslatoknak köszönhetően - pedig a prevenció egyik eszközeként is szolgálhat, ami hosszú távon is jótékonyan hat a páciensek egészségi állapotára:

„... a beteg tudja, hogy mikor mit kell csinálni, és ... a betegségének az önmenedzselése, az egyre jobban menjen..." (kardiológus, 24).

„...ez alapvetöen jó dolog lehet, mert sajnos megdöbbentöen alacsony az átlagemberek egészségügyi müveltsége Magyarországon ...” (radiológus, 11).

Egyes interjúpartnerek szerint az internetes egészségportálokon található egészséggel kapcsolatos információk és tanácsok elegendőnek bizonyulnak ahhoz is, hogy mérsékelten redukálják az egészségügyi ellátórendszer túlzott igénybevételét és nem utolsó sorban az egészségügyi szakemberek leterheltségét, ugyanis a „,..laikusok számára nyújtott szakmai tanácsadás, ami leveheti a terhet egyébként az ellátórendszerröl...” (radiológus, 5). Ehhez kapcsolódva „,...egyszerübb esetekben ... nem kell mindig minden ilyen vacak miatt orvoshoz szaladgálni, ebben segithet azért ilyen internetes oldal, vagy portál...” (radiológus, 11).

Ez a fajta szemlélet ellentétes azzal az állásponttal, ami szerint az egészségportálok nem befolyásolják jelentősen a betegszámot. Logikai érvekkel alátámasztva feltehetően mindkét álláspont megállja a helyét bizonyos esetekben.

A fentieken túl a különböző egészségportálok egyes hatásai nem csupán a kérdező páciensek aspektusából értékelhetők pozitívnak, hanem a válaszadó egészségügyi szakemberek is profitálhatnak belőle. Ennek oka pedig az orvos személyének, a praxisnak és a szaktudásnak a promotálása, a klientúra növelése, így plusz jövedelem generálása, vagyis mindkét fél számára győztes szituációként fogható fel:

„...ez egy nagyon jelentös forrása lehet a saját szakmai megitéltségének, a hierarchiában való elhelyezkedésnek, azért nagyon jó reklám..." (dermatológus, 53).

„....abban az esetben, ha fiatal lennék, és praxisépitésre törném a fejemet, akkor egész biztos, hogy hasznát venném ennek a dolognak..." (szülész-nőgyógyász, 36).

Általában a pozitívumok és negatívumok mellett - a nemzetközi szakirodalommal összhangban - megjelenik az egyenlőtlenség kérdése is, mivel a távoli egészségügyi tanácsok ebben a vonatkozásban is érintettek (NYKÄNEN, P. 2006).

Noha a páciens számos hasznos és kevésbé gyakorlatias tanáccsal is szembesül, nélkülözhetetlen egyfajta szelektációs mechanizmus. Ez pedig feltételez az adott egészségügyi témában, valamint általában az infokommunikációs technológiák (mindenekelött az internet és hatásai) világában némi jártasságot és készséget. Ebből adódóan lesznek olyanok, akik jól fogják szürni és hasznosítani az információkat, és lesznek, akik vagy teljesen kimaradnak ebböl, vagy nem élvezik a jótékony hatásait:

„....csak elbizonytalanodik, rengeteg információt hall és nem tud az információk súlyossága között szelektálni..." (háziorvos, 58).

...megfelelö intelligencia kell azért ... hogy valaki az ott kapott információt kezelni tudja... (radiológus, 13).

....szelektál, tehát aki jó ebben, tájékozódik, az túlél, aki meg nem tud benne tájékozódni az meg szétesik. Tehát lesznek olyanok valószínüleg, akiket csak összekavar a dolog... (háziorvos, 59).

Összegzésként elmondható, hogy a különböző internetes egészségportálok jelentős hatást gyakorolnak a betegekre, akik a távolból felteszik a kérdéseiket, az egészségügyi szakemberekre, akik válaszolnak rájuk és magára az ellátórendszerre, illetve az orvosokra, akikkel végül fizikai kontaktusba kerülnek a páciensek.

Mind a félig strukturált interjúk, mind pedig a tartalomelemzés eredményei arra világítanak rá, hogy csupán pozitívan, vagy negatívan nem érdemes értékelni az e-egészségügyi szolgáltatások hatásait. 
Ugyanakkor az is látható, hogy az egészségportálon feltett kérdések elemzése és annak eredménye valamelyest kedvezőbb képet mutat, mint az interjúké. Ennek oka pedig abban keresendő, hogy az egészségügyi szakemberek többsége kevésbé preferálja ezeket a szolgáltatásokat és véleményének hangot is ad. Lényegében tehát megerösítést nyer az a nemzetközi szakirodalomban is elökerült nézőpont, miszerint az orvosok alapvetően tartózkodnak az internetes egészségügyi tanácsadástól (NYKÄNEN, P. 2006). Feltehetően ennek tudható be az is, hogy az interjúpartnerek több hátrányról számolnak be, mint előnyről.

A megnevezett hátrányok között is talán a legrelevánsabb, hogy egyrészt bizonyos esetekben később kerülhetnek a páciensek az ellátórendszer látókörébe, ami kedvezőtlen lehet az egészségi állapotukra nézve. Másrészt az érem másik oldalaként megjelenhetnek a hipochonder és a „célzott” ellátást igénylők, ami azért problematikus, mert tovább növekedhet a humánerőforrás leterheltsége érdemi egészség-nyereség nélkül, illetve feszültséget generálhat ellátó és ellátott között, és ezáltal az orvos-beteg bizalmi kapcsolatot erodálja.

Ezenkívül az sem hagyható figyelmen kívül, hogy az egészségportálokon feltett kérdésekre adott válaszok többségében szerepelnek az olyan szlogenek, miszerint a betegnek érdemes felkeresni a kezelőorvosát. Ezt mind az interjúk, mind pedig a tartalomelemzés eredményei igazolják, ami arra enged következtetni, hogy az ellátórendszer leterheltségét mérsékelten redukálják ezek a szolgáltatások. Így annak ellenére, hogy a nemzetközi szakirodalom arról számol be, hogy milliós nagyságrendben veszik igénybe az internetes egészségügyi tartalmakat, ezáltal pedig jelentős csökkenés várható az ellátórendszer betegforgalmában (Matusitz, J. - Breen, G.M. 2007, Wickramasinghe, N. - Geisler, E. - Schaffer, J. 2006), hazai viszonylatban ez talán - egyelöre - kevésbé realizálódik.

Ezzel szemben a kedvező hatások sem elhanyagolhatók. Ugyanakkor ehhez szükséges elvetni minden olyan feltételezést, miszerint ez általában helyettesíti a klasszikus orvos-beteg találkozót. Az egészségportálok tanácsadói szerepe megkérdőjelezhetetlen, ami növeli a betegek egészségkultúráját, betegség észlelését, így számos pozitív hatást generálhat.

Mindenekelőtt a prevenciót, az egészségmegőrzést támogatja, hiszen az életmódbeli tanácsok és bizonyos terápiás javaslatok ezt lehetővé teszik. Hozzájárulhat az ellátórendszerben való gyorsabb megjelenéshez is azáltal, hogy a páciens törődik egészségével és felismer bizonyos szimptómákat, aminek köszönhetően akár hamarabb is megjelenik bizonyos szüréseken. Ezáltal a beteg gyorsabb diagnózishoz, kezeléshez jut, így az esetleges szövődmények is nagyobb valószínüséggel elkerülhetők.

Ezenfelül növelheti a beteg compliance-t, vagyis az orvossal való együttmüködését, amennyiben felvilágosítást kap bizonyos betegségekröl, szükséges teendökröl. Ráadásul olyan esetekben, amikor egyszerü tanácsadással kielégíthető a páciens igénye, az valamelyest redukálhatja az orvos-beteg találkozók számát is.

\subsection{A családorvosok néhány, telemedicinával kapcsolatos attitüdje}

Tekintettel arra, hogy a háziorvosi ellátás számos speciális - részben területi problémával küzd, beleértve a praxisjog értékesítés nehézségeit, az elöregedés, illetve a szakma alacsony presztízsének kérdését, a kapuőr szerep háttérbe szorulását, stb. (ÁSZ 2011, CsÁKY A. et al. 2001, RURIK I. 2009), felmerül a kérdés, hogy vajon milyen szerepet tölthet be, vagy pontosabban tölthetne be a telemedicina az alapellátásban?

Mi az oka annak, hogy ez az innovatív és hatékony ellátási forma kedvező tulajdonságai nincsenek kamatoztatva a háziorvosi ellátásban? Milyen attitüdökkel rendelkeznek maguk a családorvosok a telemedicina tekintetében? 
Részben ezek a kérdések ihlették a háziorvosok körében végzett kérdőíves adatfelvétel elkészítését (lásd Melléklet 6.), amit mindenekelött olyan orvosok töltöttek ki, akik nem kerültek még szorosabb kapcsolatba a távgyógyászattal.

A módszertani fejezetben leírtaknak megfelelően összesen 49 önkéntes családorvossal sikerült különböző szakmai (tovább)képzésen kitöltetni egy rövid, témaspecifikus kérdéssort. Tekintettel a válaszadók alacsony részvételére a százalékos számítástól az eredmények közlésében eltekintek, így az esetek számának bemutatására törekszem (BÁN A. 2017c).

A kitöltők nemi aránya kiegyenlített, ugyanis a nemüket felvállalók közül a férfiak és a nők lényegében majdnem azonos számban képviseltetik magukat (23 férfi és 25 nö). A korosztályuk igen széles spektrumon belül mozog, mivel a legfiatalabb válaszadó 27 éves, míg a legidősebb 73 éves. Ezt némileg ellensúlyozza a családorvosok átlagéletkora, illetve a késő középkorú és idősebb korosztály magasabb részvételi aránya.

A válaszadók átlagos életkora hozzávetölegesen 51 év körül alakul. A legtöbben az 51-60 éves korcsoportba tartoznak (16 fő), de ezenkívül meghatározó még a 41-50 évesek (11 fö) száma is. A kitöltők közül összesen 44 családorvos „közli” életkorát, azonban feltételezhetően a válasz megtagadók is a fenti csoportok valamelyikének táborát erősítenék. Noha a fenti adatokból - az alacsony részvételi arány miatt - általános tendencia nem vonható le, valószínüsíthetően az elöregedés irányát vetíti elöre.

Az életkorhoz hasonló szélsőséges képet mutat a háziorvosi praxisok gyakorlásának ideje is. A válaszadók közül három családorvos még vagy nem rendelkezik önálló praxissal, vagy nincs egy éve, hogy gyakorolja azt. Ezzel ellentétben a családorvosok között olyanok is találhatók, akik több mint 40 éve az alapellátásban tevékenykednek. Közülük is a legrégebbi praxissal rendelkező már 45 esztendeje családorvosként dolgozik. Ennek megfelelően az átlagos praxisidő is megközelítőleg 19 év körül alakul.

A háziorvosok közül legnagyobb csoportot azok alkotják, akik legalább 20 éve, vagy annál régebben (21 fö) gyakorolják a praxisukat, de ezenkívül jelentős azon válaszadók száma is, akiknél ugyanez az idő nem haladja meg az egy évtizedet sem (17 fö). Összességében a több évtizedes háziorvosi gyakorlattal és ennél jóval fiatalabb praxisidővel rendelkezők egyaránt képviseltetik magukat.

A háziorvosi gyakorlatban eltöltött időn túl szükséges az egyes praxisok helyének meghatározása is, tekintettel a térbeli aspektusokra. A kérdőívet kitöltök beazonosításának elkerülése érdekében - az anonimitás fenntartása céljából - település helyett a járási lépték lehet alkalmas és egyben elegendő a földrajzi szempontok vizsgálatához. A heterogén válaszok többsége (települési, járási, megyei szintek) azonban nem teszi lehetővé a lokális léptékben történő térbeli elemzést, így az eredmények összehasonlíthatóságának érdekében a közlésnél csak a megyei lépték tekinthető mérvadónak. Mindösszesen 36 háziorvos nyilatkozik a praxisának helyéről, amiből a fenti módszer eredményeként 34 esetben alkalmas a kategorizálás.

A válaszadók zöme a Dél-Alföld régió valamely településében praktizál (25 fö), amelyen belül Csongrád megye dominanciája (16 fö) figyelhető meg, amit Békés (5 fö) és BácsKiskun megye (4 fö) követ. A régió és Csongrád megye felülreprezentáltsága a háziorvosi képzések szegedi helyszínének tudható be és feltehetően a „Jarvis-féle távolsághatás törvény” (bővebben: PÁL V. - TóTH J. 2007) is érvényesül. A fentieken túl a válaszadók a fóvárosban és Pest megyében (4 fö), Jász-Nagykun-Szolnok megyében (2 fó), továbbá olyan távoli térségekben gyakorolják a hivatásukat, mint Heves megye (1 fö), vagy éppen Somogy (1 fó) és Vas megye (1 fö). Összességében tehát a Dél-Alföld felülreprezentáltsága mellett a válaszadók viszonylag szórtan helyezkednek el az országban.

A családorvosok túlnyomó többsége (41 fó) korábban már értesült a telemedicináról, annak ellenére, hogy nem alkalmazza azt. Ennek oka elsősorban, hogy a szakmai továbbképzéseken 
a távgyógyászatról is kaphatnak informatív felvilágosítást és ez a kérdöív kitöltését követő képzésen sem történt másként. Ugyanakkor még mindig vannak olyan háziorvosok (7 fö), akik nem ismerik a telemedicinális lehetőségeket.

A fentieket igazolja az is, hogy a legtöbb családorvos (23 fö) a konferenciákat és képzéseket jelöli meg, mint fő információforrást, amelyen belül a kollegiális kapcsolatok nem hagyhatók figyelmen kívül. Ezenfelül említésre méltó az internet szerepe (14 fö) a távgyógyászattal kapcsolatos ismeretek terjesztésében, de nem maradnak el a különféle szakkönyvek és folyóiratok sem (13 fö).

Összességében a családorvosok között az egyes innovációkkal kapcsolatos ismeretek diffúziójának esetében a megfelelő kapcsolati háló, az infokommunikációs technológiák és a hagyományos információs csatornák (papír alapú tudományos közlések) egyaránt meghatározók.

A kérdés azonban az, hogy maguk a háziorvosok mit tekintenek telemedicinának, illetve hogyan definiálják ezt a szolgáltatást. A válaszadók többsége (jelen esetben 37 érintettből 34 fö) érdemi, releváns és elfogadható feleletet ad a fenti kérdésekre.

A családorvosok széles körben interpretálják a telemedicinát, utalva annak diskurzív jellegére és megragadva annak lényegi elemeit. A távgyógyászat megvalósulásának fő típusait, az orvos-beteg és az orvos-orvos kontaktust egyaránt hangoztatják. Az egészségügy és az informatika integrációja szinte majdnem minden válasz esetén felmerül. Ezenkívül az információs és kommunikációs technológiák, illetve eszközök (internet, számítógép, okostelefon stb.) gyógyításban betöltött szerepét erősítik.

A térre, a helyre és a távolságra utaló kifejezések és azok átértékelődése is megjelennek, utalva a helyfüggetlenségre és a távolból történő gyógyításra. Egyes háziorvosok külön hangsúlyozzák a telemedicina néhány fentiekhez - különösen az információáramláshoz kapcsolódó előnyét, mint a gyorsabb, megbízhatóbb és hatékonyabb diagnózist és terápiás javaslatot. Ennek ellenpéldájaként megszünik a szakemberekkel és a páciensekkel történö közvetlen, face to face kapcsolat is, ami szintén megjelenik a válaszokban.

Mint korábban már történt rá utalás, a kitöltők többsége nem alkalmazza jelenleg a telemedicinát a mindennapok során, amit bizonyít a válaszadók önbevallása is (40 fö). Mindössze néhány háziorvos ( 7 fö) nyilatkozik arról, hogy használja a távgyógyászat adta lehetőségeket a praxisában. Azt azonban nem lehet tudni, hogy közülük a laboreredmények lekérésén kívül hányan alkalmaznak „tényleges” (távoli orvos-beteg, vagy orvos-orvos kontaktuson alapuló) telemedicinát is. A többségük mindössze néhány éve használja a távgyógyászatot és élvezi a vele járó előnyöket.

De vajon mi a tényleges oka annak, hogy a válaszadók többsége nem alkalmaz telemedicinát a praxisában? Az egyik legfőbb indoka feltehetően a távgyógyászattal kapcsolatos információk és ismeretek hiánya, hiszen a családorvosok leginkább (17fö) ezt a kategóriát hangsúlyozzák, és amit egyeseknek a válaszai is gyakorta tükröznek. Továbbá egyforma gyakorisággal jelentkezik az, hogy a háziorvosok időigényesnek tartják a telemedicinát (14 fö), illetve az is, hogy költségesnek vélik a távellátást és/vagy a finanszírozását hiányolják (14 fö).

Ezenfelül vannak olyan családorvosok is, akik jelenleg még plusz feladatként értékelik a távgyógyászattal kapcsolatos teendőket (10 fö), vagy éppen bonyolultnak tartják annak alkalmazását (6 fó). Ugyanakkor a dependenciától való félelem egyetlen esetben sem jelenik meg, annak ellenére, hogy a telemedicinális szolgáltatáshoz általában hozzátartozik a szakorvosokkal való kooperáció.

Az egyéb lehetőségeknél a szkepticizmus épp úgy jelentkezik, mint a távgyógyászat bevezetéséhez szükséges feltételek hiánya, vagy éppen a face to face orvos-beteg kapcsolat redukálódásától való félelem. 
Az előzőekhez szorosan kapcsolódik a telemedicina akadályozó tényezői, amelyek sok esetben meggyeznek a fentiekkel. A családorvosok véleménye szerint több barrierel is számolni kell, úgymint az egészségügyi ellátás elszemélytelenedésével, a megfelelő technikai feltételek, illetve a technológiák használatához szükséges szakértelem és kompetencia hiányával, a finanszírozás elmaradásával (a költségek vonzatában), az időigényességgel, a hagyományos munkarutin átalakulásával, vagy éppen a betegbiztonság kérdéskörével.

A telemedicina jövőbeni alkalmazása a fenti akadályozó tényezők függvénye. Amennyiben sikerül ezeket a barriereket elhárítani, úgy megnő az esélye annak, hogy a távgyógyászat a mindennapi rutin részévé váljon az alapellátásban. Jelenleg a válaszadók esetében meghatározó a bizonytalanság, mivel a családorvosok jelentős része (19 fö) nem tudja még, hogy alkalmazni fogja-e a telemedicinát. Ugyanakkor az mindenképpen pozitívumként értékelhető, hogy hasonló részvételi arányban vannak azok a háziorvosok is, akik tervezik (17 fö) a távgyógyászat bevezetését és elenyésző azoknak a száma, akik egyértelmüen elutasítják (7 fö), vagy kevésbé preferálják a távellátás alkalmazását.

Az előzőekhez kapcsolódóan egy másik kérdés a telemedicina értékelése a háziorvosok szemszögéből. Minél inkább hasznosnak tekintik a távellátást az alapellátásban, valószínüsíthetően jóval nagyobb az esély az adaptálásra. A kérdőíves adatfelvétel során egy ötös beosztású Likert skála teszi lehetővé annak mérését, hogy a családorvosok mennyire tartják relevánsnak a telemedicina használatát. Lényegében egytől (legkevésbé) ötig (leginkább) minden értékelés előfordul. A leggyakoribb érték a hármas (17 fö), amiből az következik, hogy a válaszadók többsége „átlagosnak” tartja a távgyógyászat alkalmazását, amit a számtani átlag is megerősít $(3,23)$. Ugyanakkor a második leggyakoribb kategória a négyes (11 fö), ami viszont már arra enged következtetni, hogy vannak olyan háziorvosok, akik nagyobb potenciált látnak a telemedicinában, és így feltehetően nagyobb valószínűséggel adaptálják rövidtávon belül.

Abban a tekintetben, hogy a válaszadó mindennapi munkájában előfordultak-e olyan szituációk, ahol a telemedicina segítséget jelentett volna, szintén hozzájárulhat annak elfogadásához. Noha a családorvosok többsége (27 fö) a praxisa során nem tapasztalt olyan helyzetet, ahol az ellátást támogatta volna a távgyógyászat, nem hagyható figyelmen kívül azok száma sem (19 fö), akik ennek ellenkezőjét észlelték. Ez utóbbi csoportot képviselők általában több esetről is beszámolnak.

A háziorvosok számottevő része (27 fö) reálisnak látja a telemedicinális eszközök időskori alkalmazását is, ami több szempontból releváns. Mindenekelőtt hozzájárul az alapellátás támogatásához, a különböző krónikus betegségek kontrollálásához, így az idős generáció egészségi állapotának javításához. Ebben a tekintetben meghatározó lehet az, hogy az egészségügyi paraméterek monitorozásában milyen szerepet vállal(ná)nak a családorvosok.

A fentiekhez hasonlóan egy további kérdés, hogy mit várnak el a háziorvosok a telemedicinától általában, milyen pozitív externáliákkal lehet számolni a távgyógyászat használatától. Az egyes szempontokat javarészt hasonló számban (kb. 30 fö) tekintik reálisnak a válaszadók, így jelentős differenciát nem lehet köztük tenni.

A leginkább a távoli szakorvosi vélemény, és így a speciális klinikai szakértelem, kompetencia lokális elérhetőségét ismerik el (35 fö). Az előzőből adódóan meghatározó a pontos és megbízható diagnózis hozzáférhetősége (32fö), illetve a páciensek utazási idejének és költségének redukálódása (32 fö). Ezzel ellentétben az orvoshiány csökkenését (17 fö) és a családorvosok leterheltségének mérséklését (16 fö) kevésbé tekintik reális jövőképnek.

Ezek azok a szempontok, amelyekre kevésbé nyújthat (teljes, vagy parciális) megoldást a telemedicina a válaszadók szerint. Ennek okai feltehetően abban keresendők, hogy a távgyógyászat esetében is nélkülözhetetlen az egészségügyi szakember személye, aki a paramétereket monitorozza, kontrollálja, és szükség esetén beavatkozik, vagy éppen 
„közvetítő” szerepet kap a távoli specialista és a páciens között egy adott konzultáció folyamán. Ráadásul ez a tevékenység plusz időt is igényelhet, ami a jelenlegi hagyományos munkarutinba talán kevésbé illeszthető bele. Ugyanakkor a távgyógyászat pozitívuma az elözőek ellenére nem kérdőjelezhető meg, különösen a betegek szempontjából.

Célszerü azonban tisztázni, hogy mely betegségcsoportok esetén lehet leginkább célravezető a telemedicinális eszközök használata, illetve mely területeken lehet elérni a legnagyobb egészség-nyereséget, illetve potenciált az alapellátás tekintetében. A válaszadók nem meglepően általában a krónikus betegségek esetében tartják relevánsnak a távgyógyászati lehetőségek kihasználását.

A legtöbb családorvos a cukorbetegségnél (33 fö) tudja elképzelni a telemedicina használatát, amit az ischaemiás szívbetegségek (32 fö) és a magas vérnyomás (26 fö) követ. A diabéteszes és a hipertóniás megbetegedések esetében alkalmas lehet a különbözö egészségügyi funkciókat (pl. vérnyomás, vércukor stb.) mérő készülékek alkalmazása. A távoli betegek paramétereinek monitorozása pedig nem csupán a kezelés, de a prevenció aspektusából is releváns. A családorvosok egy része a fenti betegségtípusokon túl a cerebrovascularis (agyi érbetegségek) megbetegedések (21 fö), a lipid anyagcsere betegségek (18 fö) és a légúti megbetegedések (16 fó) tekintetében sem tartja kizártnak a telemedicina használatát. Egyes válaszadók az egyéb kategórián belül pedig a sürgősségi ellátást igénylő, a fertőző, a mozgásszervi és a bőrbetegségeknél is lehetségesnek tekintik a távgyógyászat alkalmazását.

Az előzőekből is adódóan a háziorvosok többsége kardiológusokkal tudná elképzelni a kooperációt (34 fö) egy esetleges távgyógyászati szolgáltatás keretében. Ezzel párhuzamosan nem hagyható figyelmen kívül a bőrgyógyászokkal (29 fö), belgyógyászokkal (25 fö) és radiológusokkal (23 fö) való együttmüködés sem. A belgyógyászokkal és kardiológusokkal történő kooperáció alapja a korábban már ismertetett vitális paraméterek kontrollálásán alapuló konzultáció, míg a dermatológusok és radiológusok esetében a különbözö diagnosztikai képek értékelésében lehet meghatározó szerepe az együttmüködésnek.

Pozitívumként értékelhető, hogy a kérdőíves adatfelvételben résztvevő családorvosok többsége (40 fö) nem zárkózik el a telemedicinával kapcsolatos információktól és szívesen fogadja a továbbképzések keretében. Ezzel ellentétben igen csekély azon háziorvosok száma (6 fö), akik passzívan állnak a távgyógyászathoz.

Összességében elmondható, hogy noha a családorvosok nem tartják az ellátás nélkülözhetetlen részének a telemedicinát, amit az átlagos értékelés, és azon szituációk alacsony száma, ahol hiányolták volna a távellátást, szintén bizonyít. Ennek ellenére nem tagadják jelentőségét és a többségük elismeri a távgyógyászat szerepét a különböző krónikus betegségek kezelésében, a gyorsabb, hatékonyabb és megbízhatóbb minőségi ellátás irányában (BÁN A. 2017c).

A legfőbb akadályozó tényezők lényegében megegyeznek a nemzetközi szakirodalomban is ismertetett barrierekkel (WHO 2010). Ugyanakkor a kérdőíves adatfelvétel eredménye különösképpen ráirányítja a figyelmet az ismeretek hiányára. Ez feltehetően nem csak a technológia kezelésével kapcsolatos készség hiátusát jelöli, hanem a telemedicinával és annak adaptálásával kapcsolatos általános és alapvető információk deficitjét is. Ez pedig tovább növeli a szakmai konferenciák és képzések relevanciáját, amelyek lehetőség nyújtanak a távgyógyászattal kapcsolatos ismeretek parciális elsajátítására. Természetesen a telemedicina alapellátásban történő adaptálásához és alkalmazásához nélkülözhetetlen az egyes akadályok lebontása, különösen a finanszírozási problémák megszüntetése (BÁN A. 2017c). 


\section{Összegzés}

A dolgozat rámutat, hogy a telemedicina sokféleképpen értelmezhetö, mégis általánosságban elmondható, hogy egy olyan egészségügyi szolgáltatás, ami az infokommunikációs technológiák és az ellátás integrációjaként interpretálható (WHO 2010). Több részterülete is ismert, melyek a legtöbb orvosi szakterületen alkalmazhatók. Alapvetően tehát az orvostudomány és az informatika határterülete, mégis rendelkezik földrajzi aspektusokkal.

A telemedicina térbeli vonatkozásai visszavezethetők az infokommunikációs technológiák „térzsugorító” és „távolságcsökkentő” hatásaira. Ez abban mutatkozik meg, hogy az ellátás elérhetőségéhez szükséges idő lerövidül, a fizikai távolság viszont továbbra is megmarad a páciens és az ellátó között. Sem az egészségügyi szakszemélyzet, sem pedig a beteg nem utazik, csak az adatok és információk áramlanak a térben a másodperc töredéke alatt. Így a telemedicina az egészségügyi centrumoktól távoli térségek számára is biztosíthatja az ellátást jelentős távolság megtétele nélkül (FICZERE A. 2010a).

Ráadásul a hazai és a nemzetközi szakirodalom alapján az is elmondható, hogy a távgyógyászat az ellátás elérhetőségének, hozzáférhetőségének javulása mellett a (költség)hatékonyság növekedéséhez is hozzájárul. Ez pedig az ellátás szereplöit érintő utazás kiváltásában, a munkából való kimaradás redukálásában, a várakozási idő csökkenésében, a felesleges vizsgálatok minimalizálásában keresendő (FICZERE A. 2010a, MATUSITZ, J. BREEN, G.M. 2007).

Azonban ennek ellentétjeként azt is érdemes figyelembe venni, hogy a távgyógyászathoz szükséges müszaki-technikai, vagyis az infrastrukturális feltételek (csakúgy, mint általában az egészségügyi erőforrások) - az infokommunikációs technológiákhoz hasonlóan - továbbra is differenciálják a teret, így meghatározzák a telemedicinális ellátások milyenségét és minőségét (CASTELLS, M. 2005, STRÖMGREN, M. 2003).

Ráadásul az e-egészségügyi, illetve a fizetős távgyógyászati szolgáltatások igénybevételénél is megfigyelhető egyfajta marginalizáció. Lesznek ugyanis olyan személyek és társadalmi csoportok, amelyek anyagi lehetőségeiknél fogva, vagy az infokommunikációs technológiák használatához szükséges készségek hiátusában nem élvezik a telemedicina jótékony hatásait (NYKÄNEN, P. 2006). Így a távgyógyászat jelenleg az egészségügyi egyenlőtlenségek mérséklésében és újratermelésében is szerepet játszhat.

A telemedicina előzőekben felsorolt hatásai ellenére több tényező is akadályozza terjedését és adaptálását az egészségügyi ellátórendszerekben. Ezek közül érdemes kiemelni a finanszírozás teljes, vagy részleges hiányát, az egészségügyi döntéshozók, szakemberek, és a páciensek távgyógyászattal kapcsolatos negatív attitüdjét, a face to face ellátás kizárólagos preferálását. Továbbá ide tartoznak a jogi, etikai és adatvédelmi problémák, különösen a betegbiztonság és a felelősség kérdése, a szükséges müszaki-technikai tényezők hiánya (és annak kiépítésének költségei) csakúgy, mint azok kezeléséhez szükséges ismeretek és készségek hiátusa (WHO 2010). Ezek azok a tényezők, amelyek az egyes területi léptékekben barrierként jelennek meg a távgyógyászat alkalmazásánál.

Ehhez kapcsolódva érdemes figyelembe venni az adaptálással kapcsolatos döntések mögöttes tényezőit, amelyek bemutatására több elmélet is kísérletet tesz. Ezek közé tartozik ROGERS innovációs elmélete, a technológia elfogadásának és a tervezet cselekvés teóriája, a cselekvőhálózat, illetve GIDDENS strukturációs elmélete. Ezek komplex tényezők sokaságával hozzák kapcsolatba az egyén döntéseit. Ebben a tekintetben alapvető fontosságú a potenciális felhasználó technológia iránti attitűdje, de az önmagában nem elegendő. Hiszen az egyénnek több tényezőt kell mérlegelni, mint például a használat egyszerüségét, az innováció 
hasznosságát, hatásait, a rendelkezésre álló és az adaptáláshoz szükséges forrásokat, a társadalmi normákat stb. (SPIL, T.A.M. 2006).

A dolgozat elméleti keretein túl az empirikus részben több kérdés és hipotézis is felmerült. Az érdemi kutatást egy területi adatbázis létrehozása alapozza meg, amely integrálja azokat a hazai egészségügyi szolgáltatókat, amelyek telemedicinális szolgáltatást biztosítanak és/vagy igényelnek.

A disszertáció első hipotézise, miszerint az egészségügyi intézmények elenyésző hányada érintett a távgyógyászattal, lényegében megdőlt. Ennek oka ugyanis az, hogy az online kérdőív válaszadóinak több mint 40 százaléka az elmúlt években foglalkozott telemedicinával, vagy részt vett ilyen irányú szolgáltatásban. Ráadásul az érintettek fele az eredmények szerint 3-5 éve, vagy több mint 5 éve alkalmazza a távgyógyászat valamely területét (mindenekelött a teleradiológiát), így esetükben sokszor bevett gyakorlatként értékelhető és nem újonnan bevezetett innovációként.

A telemedicina prominens szereplöi (a felkeresett szakorvosok, háziorvosok, informatikusok, egészségügyi felsővezetők) az interjúk során sokszor hasonló attitüddel rendelkeznek a távgyógyászatot illetően. A telemedicina előnyeit és hátrányait, hatásait, akadályozó tényezőit egyaránt felsorakoztatják.

A távgyógyászat hatékonysági kérdései (pl. utazás, várakozás kiváltása, költségek csökkentése stb.) és az egészségügyi egyenlötlenségekre gyakorolt hatásai (pl. orvoshiány mérséklése) pozitív aspektusként jelennek meg. Míg az orvos-beteg kapcsolat elszemélytelenedése, illetve a finanszírozási környezet problémái stb. ellenérzéseket is kiváltanak egyes interjúpartnerekből. Így noha az interjúalanyok túlnyomó többsége pozitívan nyilatkozik a telemedicináról, a negatív szemlélet is megjelenik, sokszor ugyanazon interjúalany véleményében.

A családorvosok (potenciális felhasználók) körében készített kérdőíves adatfelvétel eredményei is a fentieket támasztják alá. Noha a megkérdezett háziorvosok nem feltétlen tekintik nélkülözhetetlennek a telemedicinát, ennek ellenére többségében elismerik a jótékony hatásait, különösképpen a krónikus betegségek ellenőrzésében. Azonban a válaszadók nem csupán a finanszírozás hiánya, illetve a plusz feladatok miatt nem alkalmazzák, hanem sok esetben az információk hiátusa is szerepet játszik ebben.

A telemedicina térre és távolságra gyakorolt hatásait illetően az ország mérete kisebb jelentőséggel bír, sokkal inkább a humánerőforrás területi egyenlőtlenségei, illetve annak mérséklésére való törekvés jelenik meg lényeges szempontként. Az infokommunikációs technológiákhoz köthető helyfüggetlenség és a fizikai távolság leküzdése a telemedicinális ellátásban is megjelenik. Ez pedig az ellátás elérhetőségének és hozzáférhetőségének javulásában mérhető, ami feltehetően jelentős egészség-nyereséget generál, ami visszavezethető arra, hogy nem a páciens és az orvos utazik, hanem csak az egészségügyi adat áramlik a térben. A földrajzi távolságon kívül azonban a telemedicina hatással van az interperszonális távolságra is. Bizonyos területeken tovább növelheti az ellátó és a beteg között, más helyzetekben pedig redukálhatja is.

A telemedicina hatékonysági szempontjai több irányból is megközelíthetők, amelyek visszavezethetők az infokommunikációs technológiák hatásaira. Ennek köszönhetően az utazási idő és költség, a munkaidő kiesés, a várakozási idő jelentősen redukálódik, miközben az orvosi munkaerő optimális eloszlását támogatja. Ezenfelül jelentős egészség-nyereséggel is jár, ugyanis a gyorsabb és sokszor megbízhatóbb diagnózist segíti elő.

Ráadásul a távgyógyászat egyes típusai az orvostudomány legtöbb területén alkalmazhatók, bizonyos kivételektől (pl. sürgősségi ellátás) eltekintve. És noha egyes helyzetekben a klasszikus ellátás alternatívája lehet (pl. távleletezés), alapvetően nem helyettesíti a face to face ellátást, sokkal inkább kiegészítő, komplementer szerepet kap. 
Ugyanakkor a klasszikus ellátással együtt akár jobb minőséget is produkálhat (lásd krónikus beteggondozás, monitorozás), mint önmagában a face to face ellátás.

$\mathrm{Az}$ empirikus eredmények ebben a vonatkozásban reflektálnak a cselekvőhálózat elméletre, melynek konklúziója szerint a telemedicina megfelelő hatékonyságának eléréséhez és fenntartásához szükséges a hálózat emberi és nem emberi tényezőinek harmonikus együttmüködése (LAW, J. 1992).

A telemedicina a kvalifikált humánerőforrás leterheltségét is befolyásolja. A dolgozat második hipotézise, miszerint a távgyógyászat növeli az ellátórendszerben dolgozók terhelését, csak részben igazolódott. Ennek oka, hogy az egészségügyi szakember feladatkörét és az esetszámokat növelheti a telemedicina, hiszen alapvetően nincs beépítve a rendszerbe (kivétel: távleletezés, TTEKG), vagyis nem a mindennapi rutin „kötelező” része. Ugyanakkor a távgyógyászat az orvosi munkaidő/erő hatékonyabb felhasználását is segíti. Így például egy távoli kapcsolattartás a pácienssel időben sokszor rövidebb és pszichésen kevésbé megterhelő lehet a személyes orvos találkozással szemben.

A telemedicina hatékonysága ellenére számos tényező akadályozza a terjedését és adaptálását, amelyeket az interjúpartnerek is megerősítenek, és amikről az Egészségügyi Világszervezet is beszámol (WHO 2010, 2011). Ezek közé tartoznak a finanszírozási problémák, a szükséges technikai feltételek hiátusa, illetve azok kiépítési és fenntartási költségei, a jogi és etikai kérdések, a felelősség, adatvédelem problematikája, az egészségügyi szakemberek és páciensek attitüdje, affinitása, illetve technikai felkészültsége, készségei és egy sereg egyéb tényező. Beleértve az egységes informatikai rendszer hiányát. Ezzel ellentétben az adaptálásnál releváns szerepet kap a humánerőforrás hiányból fakadó kényszer, a menedzsment és beosztottjaik hozzáállása, illetve ambíciója, továbbá a müszaki-technikai feltételek megléte.

Az adaptálással és annak gátló tényezőivel kapcsolatos eredmények értékelhetők GIDDENS strukturációs elmélete szerint. Az egészségügyi struktúra korlátokat és lehetőségeket teremt a telemedicina használatára, amelyek visszavezethetők a forrásokra és a szabályokra, esetleges társadalmi normákra. Az adaptáció többek között attól is függ, hogy az egészségügyi szereplők módosítják-e a korábban bevett gyakorlatokat (GIDDENS, A. 1984).

A távgyógyászat egészségügyi egyenlőtlenségekre gyakorolt hatásai sem hagyhatók figyelmen kívül. A disszertáció harmadik hipotézise, miszerint a telemedicina csökkenti az egészségügyi egyenlőtlenségeket, csak részben sikerült igazolni. Ez abból adódik, hogy a távgyógyászat és különösen a teleradiológia feltehetően képes mérsékelni az orvoshiányból fakadó területi differenciákat. Ez pedig lehetőséget ad arra, hogy szakemberhiánnyal rendelkező térségek és intézmények igényeit centrumokban dolgozó radiológusok elégítsék ki. Így pedig a speciális klinikai szakértelem elérhetővé váljon alacsonyabb progresszivitású intézmények számára is.

Ugyanakkor teljes megoldást valószínüleg nem jelent erre a problémára, mivel a humánerőforrás optimális kihasználtság mellett is véges, így az ellátáshoz szükséges egy bizonyos orvosi létszám. Ráadásul az infrastrukturális ellátottságban megfigyelhető területi differenciák a telemedicinára és kiváltképpen a teleradiológiai ellátásra is hatással vannak, ugyanis nem mindegy milyen minőségü felvételeket készítenek és hogyan képesek azt továbbítani (lásd internetes sávszélesség).

A telemedicina egyéb területei (lásd távfelügyelet) is jótékonyan hatnak az egészségi állapotra, azonban tekintettel a központi finanszírozás hiányára, illetve a távfelügyelet szórványos müködésére, a hozzáférésben egyenlötlenségeket generálhat. Ráadásul a telemedicina igénybevétele feltételez egyfajta készséget és képességet az infokommunikációs technológiák iránt, így félő, hogy a generációs szakadékok kiéleződhetnek. 
A telemedicina az egyenlötlenségeken felül az orvos-beteg és az egészségügyi szakemberek közti kapcsolatra is hatással van. A dolgozat negyedik hipotézise, amely szerint a távgyógyászat e viszonyrendszer redukálásával, a pácienssel való kapcsolat elszemélytelenedésével jár együtt, csak részben igazolódott. Ennek oka a telemedicina különböző részterületeiben keresendő. Általában elmondható, hogy - GIDDENS strukturációs elmélete szerint értékelve (GIDDENS, A. 1984) - a klasszikus orvos-beteg viszony megváltozik a telemedicinális ellátás során.

A teleradiológia esetében az orvos-beteg kapcsolat elszemélytelenedik, noha - egyes interjúpartnerek szerint - korábban sem volt túlságosan erős. A páciens általában nem az orvossal, hanem a szakszemélyzettel találkozik.

Ugyanakkor a telemedicina más területein (lásd távfelügyelet) az orvos-beteg kapcsolat egy minőségi változást hoz. A telemedicinális ellátást ugyanis face to face ellátás és egy szorosabb bizalmi viszony elözi meg, ami tovább erösödik a folyamatos távoli kapcsolattartás és kontroll során, még ha a fizikai találkozók száma redukálódik is. Ezzel szemben a szakemberek közötti kapcsolatot általában a kollegiális viszony és kooperáció jellemzi, ami bizonyos esetekben hierarchikus is lehet.

A távfelügyelet során az orvos-beteg kapcsolat erősödése, valamint az információs aszimmetria gyengülése nemzetközileg is releváns eredménynek számíthat (BÁN A. 2017b). Ebben a tekintetben az empirikus eredmények reflektálnak a cselekvőhálózat elméletre, miszerint a páciens és az orvos közötti bizalom erösödése függ a hálózat „,cselekvőinek” együttmüködésétől (LAW, J. 1992).

A távgyógyászat az orvos-beteg kapcsolaton túl egyéb szervezeti kérdéseket is érint. A telemedicinális szolgáltatás releváns szereplöi az expertek, akiknek a szakértelme a távoli térségekben is kamatoztatható, különösen a speciális esetek diagnosztizálásában. Továbbá nem hagyható figyelmen kívül a szakszemélyzet sem, hiszen korábban már jeleztem, hogy a páciens a teleradiológia esetében nem az orvossal, hanem az asszisztenciával találkozik, ugyanis általában ők végzik a vizsgálatot és ők a klinikai információk hordozói is. Azonban nem csupán a távleletezésben, hanem a távfelügyeletben is kulcsszereplők, mivel a betegoktatásban, a távoli adatok elökészítésében, értékelésében is fontos résztvevők.

GIDDENS strukturációs elmélete felől megközelítve az ide vonatkozó empirikus eredményeket, konklúzióként levonható, hogy a kisegítő szakszemélyzet szerepének módosulása a struktúra változását is jelenti (GIDDENS, A. 1984).

Az előzőeken felül a telemedicina a távoli egészségügyi közösségekre is hatással van, ami pozitívan és negatívan egyaránt értékelhető. Az egészségportálra vonatkozóan a félig strukturált interjúk eredménye azonban valamelyest kedvezőtlenebb képet mutat a tartalomelemzéshez viszonyítva.

A disszertáció ötödik hipotézise, miszerint az e-egészségügyi szolgáltatások (pl. egészségportál) jelentős egészség-nyereséget produkálnak és csökkentik az ellátórendszer leterheltségét, szintén csak részben igazolódott. Ezeknek a szolgáltatásoknak a pozitívuma ugyanis, hogy gyors egészségügyi tanácsot kaphatnak a betegek, ami akár redukálhatja is az orvoshoz fordulás gyakoriságát és támogathatja az egészséges életmód iránti törekvést, a compliance-t, illetve növelheti az egészségkultúra szintjét.

Ezzel ellentétben azonban az is megeshet, hogy a páciensek csupán később kerülnek az ellátórendszer látókörébe. Ugyanis mind a tartalomelemzés, mind pedig az interjúk eredményei szerint az esetek jelentős hányadában szükséges az orvoshoz fordulás. Ráadásul a hipochonder betegek miatt akár tovább is nőhet az orvosok leterheltsége, ami egyéb feszültségeket generálhat.

A disszertáció eddigi (elméleti és empirikus) eredményei több szempontból is hasznosíthatók a telemedicinával kapcsolatos kutatásokban. Mindenekelőtt a földrajzban és a 
szociológiában, de egyes elemei beépíthetök más diszciplínákba is (pl. orvostudomány, informatika). A dolgozat mindenekelőtt térbeli-társadalmi szempontból elemzi a telemedicina hatásait, ami kiindulópont lehet további társadalomtudományi kutatásokban. Ezenfelül információkkal láthat el más szakembereket (pl. orvosokat, informatikusokat) is a távgyógyászat egyes - hazai példán eddig kevésbé kutatott - aspektusait (pl. orvos-beteg kapcsolat változása) illetően.

A kvantitatív és kvalitatív vizsgálat eredményei alkalmazhatók az egészségpolitikai döntéshozatalban és az egészségügyi fejlesztésekben az ellátórendszer hatékonyságának növelése és az egészségegyenlötlenségek redukálása érdekében.

A félig strukturált interjúk eredményei ezenfelül felhasználhatók az egészségügyi szolgáltatók és szakemberek informálásához, és ezáltal a telemedicina adaptálásához.

$\mathrm{Az}$ empirikus eredmények egyes részei hasznosíthatók tájékoztatás céljából a páciensek számára is, akik nyitottak az egészségügyi innovációk iránt, és a telemedicinális szolgáltatások akceptálása és alkalmazása jótékony hatást gyakorol az egészségi állapotukra.

A jövőbeni terveket illetően fontosnak találom az eddigi empirikus kutatás bővítését, az egyes módszertani lépések további fejlesztését. Mindezt annak érdekében, hogy több irányból, minél tágabb impulzusokat kapva teljesebb képhez jussak a telemedicina hatásait illetően.

Tekintettel arra, hogy a területi adatbázis egy statikus állapotot jelez, a telemedicina (és alkalmazása) pedig folytonosan változó, dinamikus és feltörekvő területet feltételez, szükséges annak folytonos frissítése, kiegészítése további kérdőíves adatfelvételekkel, vagy a szolgáltatók telefonos, illetve online megkeresésével.

Az interjúkat mind számban, mind pedig célcsoportok diverzitását tekintve célszerünek tartom bővíteni. Az eddigiek során ugyanis jelentősen eltolódott a radiológusokkal készített interjúk száma és súlya a többi orvosi szakterülethez képest, amelyen mindenképpen változtatni szükséges. Noha ennek indoka a távleletezés felfutása, mégis fontosnak tartom az olyan interjúk számát is növelni, amelyekben a távdiagnosztika, illetve a képi leletek küldésén kívül távkonzíliumi (pl. videokonferenciás) tapasztalatokról is beszámolnak, még ha ezek száma elenyésző is.

$\mathrm{Az}$ eddigieken túl célszerünek látom az orvosi interjúk mellett tovább növelni az informatikusokkal készített interjúkat, hiszen a rendszer tervezésében és a szolgáltatás biztonságos müködtetésében releváns szerepük van. Ráadásul a kutatás során kimaradt az egészségügyi szakszemélyzet, illetve a páciensek köre. Ugyanakkor az előbbi csoport indokoltságát az adná, hogy az asszisztensek a telemedicinális ellátás kulcsszereplői, ezért attitüdjük és tapasztalataik nem hagyhatók figyelmen kívül. Míg a betegek a telemedicina (és különösen a távfelügyelet) jótékony hatásainak élvezői, akik a szolgáltatás esetleges hibáit észlelve javaslatot tehetnek annak javítására és hozzájárulhatnak a sikeres adaptáláshoz. Éppen ezért szükségesnek tartom a jelenleg még feltehetően „szórványosan előforduló” páciensek felkutatását. Noha ez jelentős kihívás, amit sok egyéb mellett a személyiségi jogok is hátráltatnak.

A telemedicina hatékonyságát számadatokkal is célszerü a jövőben alátámasztani. Ez jelentheti egyrészt a költséghatékonyság, illetve az egészségügyi eredmények kvantifikálására vonatkozó hazai és nemzetközi tanulmányok feltárását és elemzését. Másrészt pedig ilyen irányú kérdőíves adatfelvétel kivitelezését a telemedicinával érintett szolgáltatóknál.

Az előzőhöz kapcsolódóan releváns lehet néhány, már több éve működő telemedicinális szolgáltatás jellemzőinek részletes, kvalitatív vizsgálata, a ,jó gyakorlatok” bemutatása.

Érdemes lehet ezenfelül a telemedicinával érintett szolgáltatók térkapcsolatainak, vonzáskörzeteinek feltárása is kvantitatív (kérdőíves) vizsgálat segítségével. 


\section{Summary}

Telemedicine can be seen as the integration of info-communication technologies and healthcare, and thus it is an innovative form of healthcare (WHO 2010).

Due to its apparent benefits, the role that telemedicine plays in contemporary health policies and healthcare systems is becoming increasingly important, as it can be an instrument of the reduction of regional inequalities in healthcare. Its main positive effects can be observed in the improvement of the availability and accessibility of services, and thus in the creation of more equal opportunities in healthcare consumption. In addition, telemedicine can produce such results in a cost-effective way by creating more efficient resource allocation. This is mainly due to the fact that telemedicine - by using info-communication technologies enables the fast overcoming of physical distance and reduces spatial barriers (MATUSITZ, J. BREEN, G. M. 2007).

Its geographical aspect lies mainly in the fact that it provides the necessary healthcare in peripheral areas without taking significant geographical distance. Accordingly, telemedicine often makes the spatial movement of doctors and patients unnecessary and thus only medical data and information flow in space (FICZERE A. 2010a).

In connection with the above, the main problem is that the spatial and social aspect of telemedicine is an understudied area of research, despite the fact that these are fundamental parts of telemedicine service (NICOLINI, D. 2006).

In addition, another challenge is that there is no database available in Hungary that would hold information about telemedicine providers. However, such a systematic database would be a prerequisite for a spatial research on telemedicine.

Taking the above factors as a starting point, the dissertation addresses the following main research question: how does telemedicine shape the socio-spatial processes related to healthcare? This main question can be broken down into further, more detailed research questions. Which healthcare providers are involved in telemedicine? What are the effects of telemedicine on space and distance? What are the main criteria of efficiency in telemedicine? What factors obstruct/facilitate the diffusion and adaptation of telemedicine? What are the impacts of telemedicine on health inequalities? How does telemedicine affect interpersonal relationships in healthcare (e.g. between patients and doctors or other health professionals)? How does it transform distant and peripheral health communities?

Bearing these issues in mind, the principal aim of the research is to analyse the impact of telemedicine on healthcare, with particular attention to its spatial and social aspects. A further aim is to foster scientific interest in telemedicine. To answer the above research questions and to achieve the main aims, various quantitative and qualitative research methods have been applied, including questionnaires, semi-structured interviews, and content analysis.

Due to the absence of an appropriate spatial database - as noted above - primary data collection was necessary to reveal the spatial distribution of telemedicine providers and to plan the further steps of the research process. To this end, an online self-administered questionnaire seemed to be the most suitable option. This method is relatively simple and quick, and in case of closed social groups, where the range of participants can be controlled, it may provide relevant information. The starting point for the survey was the database of the National Public Health and Medical Officer Service (ÁNTSZ) which contained a list of those healthcare providers who were obliged by law to organise service on a territorial basis.

The questionnaire survey was conducted between December 2013 and April 2014. During this period, the questionnaires were sent out to a total sum of 508 email addresses and in the first round 206 completed questionnaires were returned. However, due to telephone and 
electronic mail communication with potential respondents and online information collection, a total response rate of 50 percent has been achieved.

To explore the impacts of telemedicine and to understand its operating mechanism, it was necessary to use semi-structured interviews. Potential interviewees were selected from the database of the National Healthcare Services Center (ÁEEK). I contacted those hospitals that had reported on telemedicine service in the online questionnaire. In addition, I also mobilised the social contacts and networks of the doctors already visited.

The interviews were conducted between August 2014 and October 2015. During this period, 63 interviews were made with various specialists, and to a lesser extent with general practitioners, IT specialists and healthcare managers. The majority of the interviews were face-to-face meetings, but I also conducted interviews via phone, Skype, and video conference. The average length of the interviews was approximately 40 minutes.

The interviews were supplemented with content analysis carried out between January and February 2016 to examine the impact of telemedicine on health communities. Within the framework of the content analysis, I studied the ten most popular topics of 'The doctor answers' column on a health-focused website (health portal). The questions and answers were selected by using a generator and applying a simple random sampling. My intention was to reach a 5 percent sampling rate, which ultimately brought more than 2,500 responses. These were analysed from two main aspects. On the one hand, is there direct or indirect reference in the answers to the necessity of visiting a doctor, which factor impacts the workload of people working in the healthcare system? On the other hand, does the patient get useful therapeutic advice, which may result in a considerable health gain? In addition to the interviews, a further questionnaire survey was conducted between September and October 2015 among general practitioners. The justification for doing this is that general practitioners represent a hard-toreach group among the interviewees as the majority of these people do not use telemedicine, while finding those GPs who do employ this innovative form of healthcare has turned out to be very difficult.

With the help of the staff of the Department of Family Medicine at the Faculty of Medicine, University of Szeged, a survey of 49 questionnaires was conducted during continuing education training courses, which gave insight into the attitudes of some general practitioners. Furthermore, the survey shed light on the reasons for the lack of adaptation of telemedicine in primary care, and thus its results can be used in the formation of relevant policy strategies.

The results of the online questionnaire show that from the 254 healthcare providers more than 40 percent is involved in telemedicine services in some way (for example in teleradiology or telemonitoring). Regarding their spatial distribution, these healthcare actors are from 74 different municipalities in Hungary. In addition, half of the respondents have worked with telemedicine for 3-5 years or more than 5 years, so in their case, it can be seen as a routine activity (see teleradiology).

The interviewees have different attitudes towards telemedicine accentuating both its positive and negative aspects. Given that telemedicine enables a more efficient use of healthcare resources, this has a positive impact on the doctors' point of view regarding telemedicine. However, there are some factors that unfavourably affect the attitude of those who got involved, such as financial and organizational problems as well as the healthcare service becoming impersonal. The questionnaires conducted among general practitioners' showed similar results as mentioned above. Although, general practitioners may not think telemedicine is essential part of healthcare, they do not deny its importance, instead, they acknowledge its efficiency. According to the questionnaires, among doctors, financial 
problems, information deficit, and large time investment are the main factors which mostly obstruct the use of telemedicine.

Considering the results of the interviews, the physical parameters of the country do not determine how telemedicine affects space and distance; rather the regional differences of human resource and the efforts to mitigate these differences are more important factors. The independence from geographical location and the overcoming of physical distance linked to info-communication technologies do also apply to telemedicine. This, in turn, can be measured in the improvement of availability and accessibility of healthcare services, which is likely to generate significant health gain. This can be traced back to the fact that neither the patient nor the doctor travels, instead, only healthcare data flows in space.

Efficiency aspects of telemedicine can be viewed from several points of view, which can be traced back to the effects of info-communication technologies. As a result, travel time, travel cost, loss of working time, and waiting time are reduced significantly, while it supports the optimal distribution of the workforce. In addition, it provides significant health gain, as it fosters faster and more reliable diagnosis. Telemedicine can be used in almost all areas of medicine with some exceptions (e.g. emergency medical services). Although, in some situations it may be an alternative to classic healthcare (e.g. teleradiology), basically it does not replace traditional service provision, only supplements it.

In addition, telemedicine affects the workload of people working in the healthcare system. On the one hand, it may increase the number of cases and the scope of the health professional's duties, since it is not built in the healthcare system (except teleradiology), and because it enables a faster availability of the doctor. On the other hand, telemedicine facilitates a more efficient utilization of doctors' worktime/manpower. In this way, for example, a remote contact with the patient is often shorter in time and less stressful psychologically than a physical doctor-patient interaction.

Despite the effectiveness of telemedicine, several factors impede its spread and adaptation. Such factors can be as follows: financial problems, lack of necessary technical conditions, construction and maintenance costs of technological background, legal and ethical issues, responsibility, privacy issues, attitude of health professionals and patients, the preparedness and technical skills of health professionals, and a host of other factors, including the lack of a uniform computerised system. In contrast, at the adaptation of telemedicine, the constraint that arises from the shortage of human resources has a crucial role. Furthermore, the attitude and ambitions of the management and their subordinates and the existence of technical and technological conditions are also important.

Telemedicine also has an impact on health inequalities. In some cases, it can reduce these inequalities, while in other cases it can reproduce them. Telemedicine, and teleradiology in particular, presumably can mitigate territorial differences caused by physician shortage. As a result, regions and institutions with health professional shortage are given the opportunity to satisfy their needs with radiologist working in healthcare centres. Thus, specific clinical expertise is becoming available for institutions at lower progressivity levels.

However, telemedicine does not provide a complete solution to this problem, since human resource is limited (even at the optimum level of utilisation), and a certain number of doctors is required for adequate medical service. In addition, regional differences in healthcare infrastructure also affect telemedicine and especially teleradiology services, as both the quality of images and the way they could be transmitted (see internet connection bandwidth) are equally important.

Also in telemonitoring services, where there is a need for a person who monitors the patients' health parameters (e.g. blood pressure, blood sugar) and intervenes if necessary, telemedicine can reduce the number of the personal doctor-patient meetings. However, given 
the lack of central government funding and sporadic operation, it can generate inequalities in access. In addition, the use of telemedicine presumes a sort of skills and abilities in infocommunication technologies, therefore, it is to be feared that the generation gap may widen.

Besides inequalities, telemedicine affects the relationships between doctors and patients and among health professionals. The doctor-patient relationship is being transformed, but this process can be evaluated differently in some subfields of telemedicine.

In the case of teleradiology, the doctor-patient relationship is getting impersonal, although, - according to some interview partners - it has never been too strong. The patient usually does not meet the doctor, but the professional staff.

However, in the case of telemonitoring the doctor-patient relationship brings an improvement in quality. Telemedicine service is preceded by face-to-face meetings and the development of a closer relationship of trust which is further strengthened by continuous remote communication and control, even if there is a decrease in the number of personal encounters. In contrast, the relationship between health professionals is usually characterized by collegiality and co-operation, which in certain cases can be hierarchical.

Beyond the doctor-patient relationship, telemedicine also impacts organisational structures. Experts are the relevant actors in telemedicine service, whose expertise can also be deployed in remote areas, especially in the diagnosis of special cases. Furthermore, the role of medical assistants (who support the work of doctors) cannot be overlooked, since they are key actors with respect to both teleradiology and telemonitoring.

Finally, telemedicine also affects remote healthcare communities. In this context, the utilization level of the examined health portal as well as the impact of telemedicine on the workload of health professionals can be evaluated both positively and negatively. In this respect, the results of the semi-structured interviews show somewhat less favourable picture compared to the content analysis.

The positive aspect of these services is that patients can get therapeutic advice quickly, which may reduce the frequency of the doctor-patient meetings, and it can support patients' efforts to live a healthier lifestyle and increase the level of health culture.

On the contrary, it is also possible that patients appear only later in the healthcare system. Indeed, the results of the content analysis and the interviews highlight that in a sizable proportion of the cases it is indispensable to visit a doctor. In addition, due to hypochondriac patients, the workload of doctors may even further increase, which can generate other tensions.

In the future, closer integration between sociological theories of innovation and adaptation and the research methods and empirical results may be important. It would be advisable to continuously update the existing spatial database and to incorporate new indicators into qualitative research. It would also be important to expand the number of interviewees and target groups. So far, interviews have been conducted with (medical) specialists, general practitioners, healthcare managers, and IT specialists. However, it can also be relevant to interview other health professionals (assistants, technicians) and patients.

Furthermore, confirming the effectiveness of telemedicine by quantitative data would also be useful. On the one hand, it could mean the analysis of domestic and international academic literature focusing on both cost effectiveness and the quantification of healthcare results. On the other hand, questionnaire surveys can be conducted among telemedicine providers.

In relation to the above issues, the detailed qualitative analysis of some already operating telemedicine projects/services and the presentation of "best practices" could also be relevant. Furthermore, it may worth to reveal the spatial relations and catchment area of telemedicine providers, using quantitative research methods (e.g. questionnaire survey). 


\section{Irodalomjegyzék}

1. AAS, I.H.M. 2006a: Organizational centralization in radiology. - In: Journal of Telemedicine and Telecare 12. 1. pp. 27-32.

2. AAS, I.H.M. 2006b: Organizational decentralization in radiology. - In: Journal of Telemedicine and Telecare 12. suppl. 1. pp. 1-3.

3. AAS, I.H.M. 2007: The organizational challenge for health care - From telemedicine and e-health. Arbeidsforskningsinstituttet. -The Work Research Institute, Oslo. 150 p.

4. AAS, I.H.M. 2013: The Health Sector Towards the Information Age: The Telemedicine Virtual Organization. - In: US-China Education Review B 3. 8. pp. 646-650.

5. AJZEN, I. 1991: The Theory of Planned Behavior. - In: Organizational Behavior and Human Decision Processes 50. 2. pp. 179-211.

6. ANDREWS, G.J. 2006: Geographies of health in nursing. - In: Health and Place 12. 1. pp. 110-118.

7. Andrews, G.J. - CUTChIN, M. - MCCRACKen, K. - PhilliPS, D.R. - Wiles, J. 2007: Geographical Gerontology: The constitution of a discipline. - In: Social Science and Medicine 65. 1. pp. 151-168.

8. ÁSZ 2011: Jelentés a háziorvosi ellátás müködésének és pénzügyi feltételrendszerének ellenőrzéséről. 2011. november. $104 \mathrm{p}$.

9. BABBIE, E. 2008: A társadalomtudományi kutatás gyakorlata. - Balassi Kiadó, Budapest. 723 p.

10. BAshshuR, R.L. 1997: Critical Issues in Telemedicine. - In: Telemedicine Journal and e-Health 3. 2. pp. 113-126.

11. BASHSHUR, R.L. 2000: Telemedicine Nomenclature: What Does It Mean? - In: Telemedicine Journal and e-Health 6. 1. pp. 1-3.

12. Bashshur, R.L. - ReArdon, T.G.-Shannon, G.W. 2000: Telemedicine: A New Health Care Delivery System. - In: Annual Review of Public Health 21. pp. 613-637.

13. BAshshur, R.L. - Shannon, G.W. 2009: History of telemedicine: Evolution, Context, and Transformation. - Mary Ann Liebert, Inc. New Rochelle (NY). 415 p.

14. BÁN A. 2013a: Az időskori ápolás néhány egészségföldrajzi vonatkozása - kecskeméti esettanulmányok. - In: VIKEK 5. 2. pp. 201-206.

15. BÁN A. 2013b: Az allergia morbiditásának kutatási problémái egy empirikus vizsgálat segítségével. In: BALOGH R. - SCHMIDT P. (szerk.): A földtudományi kutatások új aspektusai: tanítványok és mestereik a Kárpát-medence földtudományi kutatásában. Geographia Pannonica Nova 17. - Publikon Kiadó, Pécs. pp. 185-193.

16. BÁN A. 2013c: A telemedicina néhány egészségföldrajzi vonatkozása - Terjedést akadályozó tényezők különböző léptékekben. - In: JÓzSA K. - NAGY GY. - DUDÁS R. (szerk.): Geográfus Doktoranduszok XIII. Országos Konferenciája. - SZTE Gazdaság- és Társadalomföldrajz Tanszék, Szeged. CD-ROM (Paper 3.).

17. BÁN A. 2013d: Az egészségügyi alapellátásban alkalmazható telemedicina településföldrajzi aspektusai Magyarországon. - In: Településföldrajzi tanulmányok 2. 2. pp. 127-136.

18. BÁN A. - NAGY GY. 2013: Research possibilities in measuring allergic morbidity, using empirical data. - In: Forum geografic 12. 2. pp. 211-218.

19. BÁN A. 2014a: Telemedicinális projektek megjelenésének néhány földrajzi aspektusa. - In: Taylor gazdálkodás- és szervezéstudományi folyóirat 6. 3-4. pp. 164-170.

20. BÁN A. 2014b: A magyarországi telemedicina területiségének vizsgálata az egészségügyi szolgáltatók példáján. - In: KóROdi T. - SANSumné MolnÁR J. - SiSKÁné SzILASi B. - Dobos E. (szerk.): VII. Magyar Földrajzi Konferencia Kiadványa. - Miskolci Egyetem Földrajz-Geoinformatikai Intézet, Miskolc. pp. 83-91.

21. BÁN A. 2015: Telemedicina és földrajz: egy innovatív egészségügyi ellátási forma és a földrajzi egyenlötlenségek. - In: Földrajzi közlemények 139. 4. pp. 318-327.

22. BÁN A. - PÁL V. 2015: A telemedicina és a földrajzi egyenlőtlenségek. - In: KóSA I. - VASSÁNYI I. (szerk.): Új alapokon az egészségügyi informatika. - NJSZT, Veszprém. pp. 60-63. 
23. BÁN A. 2017a: A telekardiológia és a TTEKG megjelenése és szerepe az alapellátásban - háziorvosi interjúk tapasztalatai. - In: Interdiszciplináris Magyar Egészségügy (IME) 16. 4. pp. 41-44.

24. BÁN A. 2017b: A telemedicina hatása az orvos-beteg kapcsolat átalakulására orvosok körében végzett interjúk eredményei alapján. - In: Lege Artis Medicinae (LAM) 27. 4-5. pp. 186-192.

25. BÁN A. 2017c: A telemedicina potenciális szerepe a háziorvosi ellátás hozzáférhetőségének és minőségének javításában. - In: TORGYIK J. (szerk.): Válogatott tanulmányok a társadalomtudományok köréböl. - International Research Institute, Komárno. pp. 183-191.

26. Beuscart, R. - ChazArd, E. - Duche^Ne, J. - Ficheur, G. - Renard, J.M. - Rialle, V. - Souf, N. 2014: E-Health. - In: VenOT, A. - Burgun, A. - QuAntin, C. (eds.): Medical Informatics, e-Health Fundamentals and Applications. Springer-Verlag, Paris. pp. 405-427.

27. Boros L. 2010a: Földrajzi alapkategóriák gazdaságföldrajzi kontextusban. - In: MÉSZÁROS R. (szerk.): A globális gazdaság földrajzi dimenziói. - Akadémiai Kiadó, Budapest. pp. 40-56.

28. Boros L. 2010b: Posztstrukturalista elméletek: kihívások és lehetőségek a településföldrajz számára. In: CSAPÓ T. - KOCSIS Zs. (szerk.): A településföldrajz aktuális kérdései. VI. Településföldrajzi Konferencia. - Savaria University Press, Szombathely. pp. 392-405.

29. Boros L. 2012: Földrajz és társadalomelméletek. - In: PÁL V. (szerk.): A társadalomföldrajz lokális és globális kérdései. - Tiszteletkötet Dr. Mészáros Rezső professzor 70. születésnapja alkalmából. - SZTE TTIK Gazdaság- és Társadalomföldrajz Tanszék, Szeged. pp. 146-161.

30. Boros L. 2013: Az egészségföldrajz társadalomelméleti keretei. - In: EMBER I. - PÁL V. - TÓTH J. (szerk.): Egészségföldrajz. - Medicina Könyvkiadó Zrt., Budapest. pp. 109-133.

31. Breen, G.M. - Matusitz, J. 2010: An Evolutionary Examination of Telemedicine: A Health and Computer-Mediated Communication Perspective. - In: Social Work in Public Health 25. 1. pp. 59-71.

32. Breen, G.M. - Matusitz, J. - SousA, A. 2008: Cyberterrorism in telemedicine: A new threat to computer-mediated communication systems. - In: eHealth International Journal 4. 2. pp. 14-19.

33. Broens, T.H.F. - Huis In'T Veld, R.M.H.A. - VollenbroeK-Hutten, M.M.R. - Hermens, H.J. VAN HALTEREN, A.T. - NiEUWENHUIS, L.J.M. 2007: Determinants of successful telemedicine implementations: a literature study. - In: Journal of Telemedicine and Telecare 13. 6. pp. 303-309.

34. CARtwright, L. 2000: Reach out and heal someone: telemedicine and the globalization of health care. - In: Health 4. 3. pp. 347-377.

35. CASTElls, M. 2005: A hálózati társadalom kialakulása - Az információ kora I. kötet. - GondolatInfonia, Budapest. $662 \mathrm{p}$.

36. CHEN, SC. - LI, S.H. - LI, CY. 2011: Recent related research in technology acceptance model: a literature review. - In: Australian Journal of Business and Management Research 1. 9. pp. 124-127.

37. CHEN, J. - XIA, Z. 2009: Telehealth in China: Opportunities and challenges. - In: WoOtTON, R. PATIL, N.G. - ScOTT, R.E. - Ho, K. (eds.): Telehealth in the Developing World. - Royal Society of Medicine Press/IDRC, London. pp. 212-221.

38. CRAig, J. - PAtTerson, V. 2005: Introduction to the practice of telemedicine. - In: Journal of Telemedicine and Telecare 11. 1. pp. 3-9.

39. Cunningham, S.G. - Wake, D.J. - Waller, A. - Morris, A.D. 2014: Definitions of eHealth. - In: GAdDI, A. - CAPEllo, F. - MANCA, M. (eds.): eHealth, Care and Quality of Life. - Springer-Verlag, Milan. pp. 15-30.

40. CUTCHIN, M.P. 2002: Virtual medical geographies: conceptualizing telemedicine and regionalization. In: Progress in Human Geography 26. 1. pp. 19-39.

41. CSÁKY A. - FeJÉR L.- Misz I.I. - KIS GY.J. - KovÁCS J. - URBÁN L. 2001: Egészségügyünk az ezredfordulón. - In: AJKAY Z. et al. (szerk.): Egészségügy Magyarországon. - Magyarország az ezredfordulón. - MTA, Budapest. pp. 15-43.

42. DARAGÓ L. - ENGi Cs. - Pesti I. - VASS D. 2010: Telemedicina - IKT-n alapuló egészségügyi szolgáltatás. I. rész: rendszerkoncepció és architektúra. - In: Híradástechnika 65. 7-8. pp. 33-37.

43. DARAGÓ L. - Jung Zs. - IsPÁN F. - Bendes R. - DinYA E. 2013: A telemedicina előnyei és hátrányai. In: Orvosi Hetilap 154. 30. pp. 1167-1171.

44. Darkins, A. - Ryan, P. - Kobb, R. - Foster, L. - Edmonson, E. - WAKefield, B. - LAnCAster, A.E. 2008: Care Coordination/Home Telehealth: the systematic implementation of health informatics, home 
telehealth, and disease management to support the care of veteran patients with chronic conditions. - In: Telemedicine and e-Health 14. 10. pp. 1118-1126.

45. DiCKen, P. 2011: Global Shift - Mapping the Changing Contours of the World Economy. - Sixth Edition. The Guilford Press, New York. 608 p.

46. DZENOWAGIS, J. 2009: Bridging the digital divide: Linking health and ICT policy. - In: WoOTTON, R. PATIL, N.G. - ScOTT, R.E. - Ho, K. (eds.): Telehealth in the Developing World. - Royal Society of Medicine Press/IDRC, London. pp. 9-26.

47. DUDÁs G. 2013: A világvárosok térkapcsolatainak vizsgálata légi közlekedési adatok felhasználásával. Doktori (PhD) értekezés. - Szegedi Tudományegyetem, Szeged. 172 p.

48. EÁS 2015: „Egészséges Magyarország 2014-2020”. - EMMI Egészségügyért Felelős Államtitkárság, Budapest. $106 \mathrm{p}$.

49. ERDÖSI F. 2003: Globalizáció és a világvárosok által uralt tér. - In: Tér és Társadalom 17. 3. pp. 1-27.

50. FICZERE A. 2010a: Telemedicina. - In: Interdiszciplináris Magyar Egészségügy 9. 1. pp. 48-50.

51. FICZERE A. 2010b: A telemedicina jelene és jövőképe II. - In: Interdiszciplináris Magyar Egészségügy 9. 3. pp. 53-55.

52. FICZERE A. 2012a: A telemedicina alkalmazási lehetőségei. - In: Kórház. 3. pp. 41-42.

53. FICZERE A. 2012b: Telemedicina a mai magyar egészségügyben. - In: Kórház 18. 4. szám. pp. 34-36.

54. FICZERE A. 2012c: Telemedicina szolgáltatás bevezetéséhez szükséges lépések. - In: Interdiszciplináris Magyar Egészségügy 11. 10. pp. 80-82.

55. FICZERE A. - KÖDMÖN J. 2011: Telemedicina. - In: Kórház 17. 11. pp. 42-43.

56. Finch, T. - MAY, C. - Mort, M. - MAIR, F. 2006: Telemedicine, Telecare and the Future Patient: Innovation, Risk and Governance. - In: WeBster, A. (ed.): New Technologies in Health Care Challenge, Change and Innovation. - Palgrave Macmillan, Basingstoke and New York. pp. 84-96.

57. Gagnon, M.P. - Desmartis, M. - Labrecque, M. - Car, J. - Pagliari, C. - Pluye, P. - Frémont, P. - Gagnon, J. - Tremblay, N. - LÉGaré, F. 2012: Systematic Review of Factors Influencing the Adoption of Information and Communication Technologies by Healthcare Professionals. - In: Journal of Medical Systems 36. 1. pp. 241-277.

58. GagnON, M.P. - DUPlantie, J. - FORTIN, J.P. - LANDRY, R. 2006: Implementing telehealth to support medical practice in rural/remote regions: what are the conditions for success? - In: Implementation Science 1. 1. (18) $8 \mathrm{p}$.

59. Gagnon, M.P. - Lamothe, L. - Fortin, J.P. - Cloutier, A. - Godin, G. - Gagné, C. - Reinharz, D. 2004: The Impact of Organizational Characteristics on Telehealth Adoption by Hospitals. - 37th Hawaii International Conference on System Sciences, IEEE Computer Society. Track 6.

60. Gagnon, M.P. - Ngangue, P. - Gagnon, J.P. - Desmartis, M. 2015: m-Health adoption by healthcare professionals: a systematic review. - In: Journal of the American Medical Informatics Association 23. 1. pp. 212-220.

61. GIDDENS, A. 1984: The Constitution of Society - Outline of the Theory of Structuration. - University of California Press, Berkeley and Los Angeles. 402 p.

62. GidDEns, A. 2008: Szociológia. - Második kiadás - Osiris Kiadó, Budapest. 833 p.

63. GombÁs P. - SkePPer, J.N. - KRENÁCs T. - MolNÁR B. - HegYi L. 2004: A digitális patológia múltja, jelene és jövője. - In: Orvosi Hetilap 145. 8. pp. 433-443.

64. GomBÁs P. - SzENDE B. - STOTZ GY. 1996: Telekommunikációs döntéstámogatás a diagnosztikus patológiában. Tapasztalatok az első hazai telepatológiai rendszerrel. - In: Orvosi Hetilap 137. 42. pp. 2299-2303.

65. GombÁs P. - SzEnde B. - StOtZ Gy. 2000: Digitális patológia - a telepatológia alapjai. - In: Lege Artis Medicinae 10. 11-12. pp. 848-854.

66. GRAHAM, S. 1998: The end of geography or the explosion of place? Conceptualizing space, place and information technology. - In: Progress in Human Geography 22. 2. pp. 165-185.

67. Greenhalgh, T. - StONES, R. 2010: Theorising big IT programmes in healthcare: Strong structuration theory meets actor-network theory. - In: Social Science and Medicine 70. 9. pp. 1285-1294. 
68. Grigsby, J. 1997: Telemedicine in the United States. - In: BASHSHUR, R.L. - SANDERS, J.H. Shannon, G.W. (eds.): Telemedicine: Technology and Practice. - Charles C. Thomas, Springfield. pp. 291-325.

69. Grigsby, J. - Rigby, M. - Hiemstra, A. - House, M. - Olsson, S. - Whitten, P. 2002: The diffusion of telemedicine. - In: Telemedicine Journal and e-Health 8. 1. pp. 79-94.

70. Groves, P.S. - Meisenbach, R.J. - ScotT-Cawiezell, J. 2011: Keeping patients safe in healthcare organizations: a structuration theory of safety culture. - In: Journal of Advanced Nursing 67. 8. pp. 1846-1855.

71. HAIDEGGER T. 2010: A robotsebészet hódítása - sikerek, kudarcok, kihívások. - In: Orvosi Hetilap 151. 41. pp. 1690-1696.

72. Harvey, D. 1989: The Condition of Postmodernity - An Enquiry into the Origins of Cultural Change. - Blackwell, Oxford. 378 p.

73. Hassol, A. - Irvin, C. - Gaumer, G. - Puskin, D. - Mintzer, C. - Grigsby, J. 1997: Rural applications of telemedicine. - In: Telemedicine Journal and e-Health 3. 3. pp. 215-225.

74. HÉRA G. - Ligeti Gy. 2005: Módszertan - A társadalmi jelenségek kutatása. - Osiris Kiadó, Budapest. $371 \mathrm{p}$.

75. Holden, R.J. - KARSH, BT. 2010: The technology acceptance model: its past and its future in health care. - In: Journal of Biomedical Informatics 43. 1. pp. 159-172.

76. HozNeK A. 2008: History of Robotic Surgery in Urology. - In: HubERT, J. - WiKLUnD, P. (eds.): Robotic Urology. - Springer-Verlag, Berlin-Heidelberg. pp. 1-9.

77. Hu, P.J. - Chau, P.Y.K. - SHENG, O.R.L. - TAM, K.Y. 1999: Examining the Technology Acceptance Model Using Physician Acceptance of TelemedicineTechnology. - In: Journal of Management Information Systems 16. 2. pp. 91-112.

78. JАКОВі Á. 2007: Az információs társadalom térbelisége - A kötet a szerző „Hagyományos és új területi különbségek az információs társadalomban" címü $\mathrm{PhD}$ értekezésének felhasználásával készült. - ELTE Regionális Földrajzi Tanszék, Budapest. 166 p

79. Jones, M.R. - KARSTEN, H. 2008: Giddens's Structuration Theory and Information Systems Research. In: MIS Quarterly 32. 1. pp. 127-157.

80. JÓHANNESSON, G.T. - BAERENHOLDT, J.O. 2009: Actor-Network Theory/Network Geographies. - In: KITCHIN, R. - THRIFT, N. (ed.): International Encyclopedia of Human Geography. - Elsevier, Amsterdam 1. pp. 15-19.

81. KISS, J.P. 2013: A hazai egészségügyi szakellátások területei kérdései. - In: EMBER I. - PÁL V. - TÓTH J. (szerk.): Egészségföldrajz. - Medicina Könyvkiadó Zrt., Budapest. pp. 393-426.

82. KOVÁCS P. - PIRISI G. - TRÓCSÁNYI A. 2013: Az egészségügyi alapellátó és sürgősségi rendszer területi képe. - In: EMBER I. - PÁL V. - TÓTH J. (szerk.): Egészségföldrajz. - Medicina Könyvkiadó Zrt., Budapest. pp. 378-392.

83. KovÁCs Z. 2010: Népesség- és településföldrajz. - ELTE Eötvös Kiadó, Budapest. 239 p.

84. KrishnA, M.T. - KNIBB, R.C. - Huissoon, A.P. 2016: Is there a role for telemedicine in adult allergy services? - In: Clinical \& Experimental Allergy 46. 5. pp. 668-677.

85. KSH 2015: Európai lakossági egészségfelmérés, 2014. - In: Statisztikai tükör 2015/29. 9 p.

86. LAw, J. 1992: Notes on the Theory of Actor-Network: Ordering, Strategy, and Heterogeneity. - In: Systems Practise 5. 4. pp. 379-393.

87. Lehoux, P. - Sicotte, C. - Denis, J.L. - Berg, M. - LACroiX, A. 2002: The theory of use behind telemedicine: how compatible with physicians' clinical routines? - In: Social Science and Medicine 54. 6. pp. 889-904.

88. LEVERT, D. 2010: Telemedicine: Revamping Quality Healthcare in Rural America. - In: Annals of Health Law 19. 2. pp. 215-226.

89. Lippuner, R. - Werlen, B. 2009: Structuration Theory. - In: Kitchin, R. - Thrift, N. (ed.): International Encyclopedia of Human Geography. - Elsevier, Amsterdam 11. pp. 39-49. 
90. LoPEZ, A.M. 2014: Telemedicine, Telehealth, and e-Health Technologies in Cancer Prevention. - In: Alberts, D. - Hess, L.M. (eds.): Fundamentals of Cancer Prevention - Third Edition. - SpringerVerlag, Berlin-Heidelberg. pp. 259-277.

91. MARs, M. 2009: Telemedicine in sub-Saharan Africa. - In: Wootton, R. - PAtil, N.G. - Scott, R.E. Ho, K. (eds.): Telehealth in the Developing World. - Royal Society of Medicine Press/IDRC, London. pp. 232-241.

92. MARS, M. 2013: Telemedicine and Advances in Urban and Rural Healthcare Delivery in Africa. - In: Progress in cardiovascular diseases 56. 3. pp. 326-335.

93. MARS, M. - SCOTT, R.E. 2010: Global e-health policy: a work in progress. - In: Health Affairs 29. 2. pp. 239-245.

94. MARS, M. - ScOtT, R. 2012: Telemedicine Service Use: A New Metric. - In: Journal of Medical Internet Research 14. 6. (e178) 6 p.

95. May, C. - Harrison, R. - Finch, T. - Macfarlane, A. - Mair, F. - Wallace, P. 2003: Understanding the normalization of telemedicine services through qualitative evaluation. - In: Journal of the American Medical Informatics Association 10. 6. pp. 596-604.

96. MAtusitZ, J. - BReEn, G.M. 2007: Telemedicine: its effects on health communication. - In: Health Communication 21. 1. pp. 73-83.

97. McBain, L. - Morgan, D. 2005: Telehealth, Geography, and Jurisdiction - Issues of Healthcare Delivery in Northern Saskatchewan. - In: Canadian Woman Studies 24. 4. pp. 123-129.

98. MCPheE, R.D. - PoOle, M.S. - IVERSON, J. 2014: Structuration Theory. - In: PutnAM, L.L. - MuMBY, D.K. (eds.): The SAGE Handbook of Organizational Communication. - Advances in Theory, Research, and Methods - Third Edition - SAGE, Thousand Oaks. pp. 75-99.

99. Meade, M.S. - EMCH, M. 2010: Medical Geography - Third edition. - The Guilford Press, New York. $498 \mathrm{p}$.

100.MÉSZÁROS R. 2001: A kibertér társadalomföldrajzi megközelítése. - In: Magyar Tudomány 48. 7. pp. 769-779.

101.MÉSZÁROS R. 2008: A kibertér, és ami körülötte van. - JATEPress, Szeged. 168 p.

102.MÉSZÁROS R. 2010a: Alapkategóriák, összefüggések, példák. - In: MÉSZÁROS R. (szerk.): A globális gazdaság földrajzi dimenziói. - Akadémiai Kiadó, Budapest. pp. 21-39.

103.MÉSZÁros R. 2010b: A globális kibertér. - In: MÉSZÁros R. (szerk.): A globális gazdaság földrajzi dimenziói. - Akadémiai Kiadó, Budapest. pp. 349-365.

104.MoRGAN, K. 2001: The Exaggerated Death of Geography: Localised Learning, Innovation and Uneven Development. - The Future of Innovation Studies Conference, The Eindhoven Centre for Innovation Studies, Eindhoven University of Technology, 20-23 September 2001. 33 p.

105.Mort, M. - MaY, C. R. - Williams, T. 2003: Remote Doctors and Absent Patients: Acting at a Distance in Telemedicine? - In: Science, Technology \& Human Values 28. 2. pp. 274-295.

106. Murray, E. - Burns, J. - MaY, C. - Finch, T. - O’Donnell, C. - Wallace, P. - MAIR, F. 2011: Why is it difficult to implement e-health initiatives? A qualitative study. - In: Implementation Science 6. 1. (6) $11 \mathrm{p}$.

107.NAGY G. 2003: Regionalitás és információs társadalom. - In: NAGY G. - KANALAS I. (szerk.): Régiók az információs társadalomban. - MTA RKK ATI, Kecskemét. pp. 77-117.

108.NAGY G. 2010: Az info-kommunikációs eszközök, rendszerek fejlődése, terjedése. - In: MÉSZÁROS R. (szerk.): A globális gazdaság földrajzi dimenziói. - Akadémiai Kiadó, Budapest. pp. 311-320.

109.NAKAMURA, T. 2007: The development of medical networks through ICT in Japan. - In: NETCOM 21. 3-4. pp. 363-380.

110.NÉMEdi D. - LAKATOS L. - RÓBERT P. - SOMLAi P. 2007: A modern szociológia paradigmái. Munkabeszámoló. OTKA. 16 p.

111. NiCOLINI, D. 2006: The work to make telemedicine work: A social and articulative view. - In: Social Science and Medicine 62. 11. pp. 2754-2767.

112. NiCOLINI, D. 2007: Stretching out and expanding work practices in time and space: The case of telemedicine. - In: Human Relations 60. 6. pp. 889-920. 
113.NMRC 2007: Overcoming the psychological barriers to telemedicine: empowering older americans' to use remote health monitoring services. New Millennium Research Council. 2007. 22 p.

114.NYKÄNEN, P. 2006: E-Health Systems: Their Use and Visions for the Future. - In: SPIL, T.A.M. SCHURING, R.W. (ed.): E-Health Systems Diffusion and Use: The Innovation, the User and the Use IT Model. - Idea Group Publishing, Hershey. pp. 281-293.

115.OROSZ É. 2001: Félúton vagy tévúton? Egészségügyünk félmúltja és az egészségpolitika alternatívái. Egészséges Magyarországért Egyesület, Budapest. 327 p.

116. OrRuño, E. - Gagnon, M.P. - AsuA, J. - ABdelJelil, A.B. 2011: Evaluation of teledermatology adoption by health-care professionals using a modified Technology Acceptance Model. - In: Journal of Telemedicine and Telecare 17. 6. pp. 303-307.

117. OudSHOORN, N. 2008: Diagnosis at a distance: the invisible work of patients and healthcare professionals in cardiac telemonitoring technology. - In: Sociology of Health \& Illness 30. 2. pp. 272 288.

118.PARK, S.Y. 2009: An Analysis of the Technology Acceptance Model in Understanding University Students' Behavioral Intention to Use e-Learning. - In: Journal of Educational Technology \& Society 12. 3. pp. 150-162.

119.PÁL V. 2002: Egészségföldrajz. - In: TóTH J. (szerk.): Általános társadalomföldrajz I. - Dialóg Campus Kiadó, Budapest - Pécs. pp. 382-414.

120.PÁL V. 2005: Fogalmi kérdések, történeti csomópontok, kutatási irányzatok az egészségföldrajzban. In: Földrajzi értesítő 53. 3-4. pp. 435-453.

121.PÁL V. 2009: Új megközelítési módok, kutatási irányok a nemzetközi egészségföldrajzban. - KözépEurópai közlemények 2. 6-7. pp. 21-28.

122.PÁL V. 2010: Egészségföldrajz. - In: TóтH J. (szerk.): Világföldrajz. Akadémiai Kiadó, Budapest. pp. 597-618.

123.PÁL V. 2012: A perifériahelyzet és az egészségi állapot - egy ormánsági kutatás tapasztalatai. - In: Falu 28. 1. pp. 29-40.

124.PÁL V. 2013: Elmaradott térségek lokális egészségkonfliktusai: sajátosságok és problémák a sellyei kistérség népességének egészségi állapotában. - In: EMBER I. - PÁL V. - TÓTH J. (szerk.): Egészségföldrajz. - Medicina Könyvkiadó Zrt., Budapest. pp. 484-503.

125.PÁL V. - BOROS L. 2013: Új jelenségek, irányzatok az egészségföldrajzban. - In: EMBER I. - PÁL V. TÓTH J. (szerk.): Egészségföldrajz. - Medicina Könyvkiadó Zrt., Budapest. pp. 79-97.

126.PÁL, V. - KISS, J.P. - TIPEI, A. 2006: A survey of regional differences in health conditions of hungarian patients on the basis of hospital admissions. - In: Magyar Epidemiológia 3. 2. pp. 83-96.

127.PÁL V. - TóTH J. 2007: Egészségföldrajz. - Lomart Kiadó, Pécs-Gyula. 268 p.

128.PÁl V. - Uzzoli A. 2008: Az emberiség egészsége - a 21 század kihívásai. - In: Földrajzi Közlemények 132. 4. pp. 471-488.

129.PÁl V. - Uzzoli A. 2010: Az életesélyek földrajzi különbségei és társadalmi kihívásai a világon. - In: TOMPÁNÉ DAuBner K. - MiKLÓSNÉ ZAKAR A. - BALÁZS J. (szerk.): Tudományos Mozaik, 7. kötet. Tomori Pál Főiskola, Kalocsa. pp. 217-226.

130.PÁL V. - Uzzoli A. 2013: Egészségi és egészségügyi problémák a gazdasági fejlettség függvényében regionális és globális léptékben. - In: EMBER I. - PÁL V. - TÓTH J. (szerk.): Egészségföldrajz. Medicina Könyvkiadó Zrt., Budapest. pp. 203-219.

131.P. BORBÉLY É. 2011: Számítógépek társadalmi konstrukciója a XX. század közepén. Technikafejlődéselméletek és hálózatkutatási módszerek alkalmazása a számítógépek korai fejlődésének vizsgálatában. Doktori (PhD) értekezés. - Budapesti Müszaki és Gazdaságtudományi Egyetem, Gazdaságtudományi Kar, Budapest. 111 p.

132.RAKONCZAI J. 2008: Globális környezeti kihívásaink. - Universitas Szeged Kiadó, Szeged. 204 p.

133.RITZER, G. 2005 : Encyclopedia of Social Theory. - SAGE, Thousand Oaks 1. pp. 1-3.

134.Rogers, E.M. 1983: Diffusion of innovations. - Third edition. - The Free Press. - A division of Macmillan Publishing Co., New York. 453 p. 
135.Rogove, H.J. - MCARThuR, D. - DemaerschalK, B.M. - Vespa, P.M. 2012: Barriers to telemedicine: survey of current users in acute care units. - In: Telemedicine and e-Health 18. 1. pp. 48-53.

136.RURIK I. 2009: Gondok és útkeresés a háziorvoslásban. - In: Orvosi Hetilap 150. 34. pp. 1615-1622.

137.SADAN, E. 2011: Közösségi tervezés és empowerment. - Luxor Grafika Kft. ford., ELTE TáTK, Budapest. 211 p.

138.SANDERs, C. - Rogers, A. - Bowen, R. - Bower, P. - HiRANi, S. - CARTwright, M. - FitzPATRICK, R. - KnapP, M. - BARlow, J. - Hendy, J. - ChrysanthaKi, T. - BARdSley, M. - NewMan, S.P. 2012: Exploring barriers to participation and adoption of telehealth and telecare within the Whole System Demonstrator trial: a qualitative study. - In: BMC Health Services Research 12. 1. (220) 12 p.

139.SÁNDOR J. 1999: Területi egyenlőtlenségek epidemiológiai elemzése. - In: Orvosi Hetilap 140. 1. pp. 21-28.

140.SÁNDOR J. - MÁtÉ M. - IRTÓ I. - ZÁBORSZKY A. - BENEDEK GY. - STERLIK G. - REGÖLY-MÉREI J. 2001: Határtalan sebészet. - In: Magyar sebészet 54. 5. pp. 303-306.

141.SChAPER, L. - PERVAN, G. 2004: A Model of Information and Communication Technology Acceptance and Utilisation by Occupational Therapists. - In: Decision Support in an Uncertain and Complex World: The IFIP TC8/WG8.3 International Conference 2004. DSS2004 Conference Proceedings. pp. 734-744.

142.SCOTT, R.E. 2009: Global e-health policy: From concept to strategy. - In: WoOTTON, R. - PATIL, N. G. - ScotT, R. E. - Ho, K. (eds.): Telehealth in the Developing World. - Royal Society of Medicine Press/IDRC, London. pp. 55-67.

143.SIK D. 2013: Giddens Társadalomelmélete. - In: Társadalomkutatás 31. 1. pp. 55-71.

144.SMith, A.C. - Bensink, M. - ARMFIELD, N. - STILlMAn, J. - CAFFERY, L. 2005: Telemedicine and rural health care applications. - In: Journal of Postgraduate Medicine 51. 4. pp. 286-293.

145.Smith, J.R. - TerRy, D.J. - MAnstead, A.S.R. - Louis, W.R. - KotTERMAN, D. - WolfS, J. 2007: Interaction Effects in the Theory of Planned Behavior: The Interplay of Self-Identity and Past Behavior. - In: Journal of Applied Social Psychology 37. 11. pp. 2726-2750.

146.Sood, S.P. - NeGash, S - MbariKA, V.W. - KIFLE, M. - PrAKASH, N. 2007: Differences in public and private sector adoption of telemedicine: Indian case study for sectoral adoption. - In: Studies in Health Technology and Informatics 130. pp. 257-268.

147.SPIL, T.A.M. 2006: User Acceptance and Diffusion of Innovations Summarized. - In: SPIL, T.A.M. SCHURING, R.W. (ed.): E-Health Systems Diffusion and Use: The Innovation, the User and the Use IT Model. - Idea Group Publishing, Hershey. pp. 1-12.

148.STANBERRY, B. 2000: Telemedicine: barriers and opportunities in the 21st century. - In: Journal of Internal Medicine 247. 6. pp. 615-628.

149.Starren, J.B. - NesbitT, T.S. - Chiang, M.F. 2014: Telehealth. - In: ShorTlifFe, E.H. - Cimino, J.J. (eds.): Biomedical Informatics - Computer Applications in Health Care and Biomedicine. - SpringerVerlag, London. pp. 541-560.

150.StrÖMgren, M. 2003: Spatial diffusion of telemedicine in Sweden. - Doctoral dissertation in Social and Economic Geography at the Faculty of Social Sciences, Umeå University. 163 p.

151.SUN, Y. - WANG, N. - GUO, X. - PENG, Z. 2013: Understanding the acceptance of mobile health services: A comparison and integration of alternative models. - In: Journal of Electronic Commerce Research 14. 2. pp. 183-200.

152.SzABARI V. 2007: A társulások szociológiája. - In: Szociológiai Szemle 17. 1-2. pp. 109-118.

153.SzABÓ CS.A. - JÁVOR A. 2008: Távgyógyászati alkalmazások. - In: Híradástechnika 63. 2. pp. 9-14.

154.SZILÁGYI D. - UZZOLI A. 2013: Az egészségegyenlőtlenségek területi alakulása az 1990 utáni válságok idején Magyarországon. - In: Területi statisztika 53. 2. pp. 130-147.

155.TANRIVERDI, H. - IACONO, C.S. 1999: Diffusion of telemedicine: a knowledge barrier perspective. - In: Telemedicine Journal and e-Health 5. 3. pp. 223-244.

156.TAYLOR, P. 2005: Evaluating telemedicine systems and services. - In: Journal of Telemedicine and Telecare 11. 4. pp. 167-177. 
157.TINER T. 2004: A hazai mobiltelefónia területi terjedésének néhány sajátossága. - In: Földrajzi Értesítő 53. 3-4. pp. 237-246.

158.TÖröK M. - DrÁvUCz S. - KovÁCs F. - SpÁNIK G. - Di LIETO, A. 2007: A szülészet-nőgyógyászati távgyógyászat (telemedicina) múltja, jelene és jövője (?) Magyarországon. - In: Nőgyógyászati és Szülészeti Továbbképző Szemle 9. 4. pp. 154-159.

159.TÚRY F. - VINCZE G. 2008: Telemedicina. - In: PILling J. (szerk.): Orvosi kommunikáció. - Medicina Könyvkiadó Zrt., Budapest. pp. 373-386.

160.Uzzoli A. 2008: Az egészségi állapot világméretű különbségei. - In: Földrajzi Értesítő 57. 3-4. pp. $399-415$.

161.UzZOLI A. 2009: Zárójelentés: „A területiség szerepe az egészségügyi egyenlőtlenségek kialakulásában Magyarországon” - PF63859 nyilvántartási számú OTKA Egyéni Kutatási Posztdoktori Pályázat (2006-2009). 93 p.

162.UZZOLI A. 2012: Connection between health inequalities and the recent economic crisis in Hungary. In: Berghauer S. - DNYISZTRJANSZKiJ M. - FOdOR GY. - GÖNCZY S. - IZSÁK T. - MOLNÁR J. MolNÁR D.I. (szerk.): Társadalomföldrajzi kihívások a XXI. század Kelet-Közép-Európájában I. kötet. - II. Rákóczi Ferenc Kárpátaljai Magyar Főiskola, Beregszász. pp. 429-435.

163.UzZOLI A. - SzILÁGYI D. 2013: A nyugat-kelet és a centrum periféria relációk a hazai egészségegyenlőtlenségek alakulásában az 1990 utáni válságok idején Magyarországon. - In: Területi Statisztika 53. 4. pp. 306-321.

164.Uzzoli A. - VitRAi J. - BAKACs M. - GÉMES K. - Kiss N. - KöVI R. 2011: A lakóhelytől függ az esély a jobb minőségű ellátásra - Az ellátáshoz való hozzáférés területi egyenlőtlenségei Magyarországon, a szürkehályogmütétek példáján. - In: Tér és Társadalom 25. 2. pp. 88-105.

165.VINCZE G. - TÚRY F. - RESS K. 2004: A telemedicina térhódítása. - In: Mentálhigiéné és Pszichoszomatika 5. 3. pp. 213-226.

166. Vitrai J. - HeRmANn D. - KABOS S. - KAPOSVÁRi Cs. - LŐW A. - PÁTHY Á. - VÁrhalmi Z. 2008 : Egészség-egyenlőtlenségek Magyarországon - Adatok az ellátási szükségletek térségi egyenlőtlenségeinek becsléséhez. - In: EgészségMonitor Kutató és Tanácsadó Nonprofit Közhasznú Kft., Budapest. 106 p.

167.VITRAi J. - BAKACS M. - GÉMES K. - Kiss N. - KÖVI R. - UzzOLI A. 2011: Egészségügyi ellátáshoz való hozzáférés egyenlőtlenségei Magyarországon. - In: Interdiszciplináris Magyar Egészségügy 10. 2. pp. 12-16.

168. Whitten, P. - Holtz, B. - NGuYen, L. 2010: Keys to a successful and sustainable telemedicine program. - In: International Journal of Technology Assessment in Health Care 26. 2. pp. 211-216.

169.WHO 2010: Telemedicine. Opportunities and developments in Member States. Report on the second global survey on eHealth. Global Observatory for eHealth series. - Volume 2. 96 p.

170.WHO 2011: Atlas eHealth country profiles. Based on the findings of the second global survey on eHealth. Global Observatory for eHealth series. - Volume 1. 230 p.

171.WHO 2012: The bigger picture for e-health. - Bulletin of the World Health Organization 90. 5. pp. 330331.

172.WiCKRAmasinghe, N. - Geisler, E. - Schaffer, J. 2006: Assessing E-Health. - In: SpIL, T.A.M. SCHURING, R.W. (ed.): E-Health Systems Diffusion and Use: The Innovation, the User and the Use IT Model. - Idea Group Publishing, Hershey. pp. 294-323.

173. WootTon, R. 1999: Telemedicine and isolated communities: a UK perspective. - In: Journal of Telemedicine and Telecare 5. 2. pp. 27-34.

174. WootTON, R. 2001: Telemedicine and developing countries - successful implementation will require a shared approach. - In: Journal of Telemedicine and Telecare 7. Suppl. 1. pp. 1-6.

175.WootTon, R. 2008: Telemedicine support for the developing world. - In: Journal of Telemedicine and Telecare 14. 3. pp. 109-114.

176. WootTon, R. 2009: The future use of telehealth in the developing world. - In: WootTON, R. - PATIL, N.G. - ScOTT, R.E. - Ho, K. (eds.): Telehealth in the Developing World. - Royal Society of Medicine Press/IDRC, London. pp. 299-308. 
177.Wootton, R. 2012: Twenty years of telemedicine in chronic disease management - an evidence synthesis. - In: Journal of Telemedicine and Telecare 18. 4. pp. 211-220.

178. WootTon, R. - BAHAADinBeIGY, K. - HAILEY, D. 2011: Estimating travel reduction associated with the use of telemedicine by patients and healthcare professionals: proposal for quantitative synthesis in a systematic review. - In: BMC Health Services Research 11. 1. (185) 10 p.

179. WootTon, R. - BonnARDot, L. 2010: In what circumstances is telemedicine appropriate in the developing world? - In: Journal of the Royal Society of Medicine Short Reports 1. 5. pp. 1-11.

180.Wootton, R. - Geissbuhler, A. - Jethwani, K. - Kovarik, C. - Person, D.A. - Vladzymyrskyy, A. - ZANABONI, P. - ZOLFO, M. 2012: Long-running telemedicine networks delivering humanitarian services: experience, performance and scientific output. - In: Bulletin of the World Health Organization 90. 5. pp. 341-347.

181.ZANABONI, P. - KNARVIK, U. - WoOtTON, R. 2014: Adoption of routine telemedicine in Norway: the current picture. - In: Global Health Action 7. (22801) 13 p.

182.ZANABOni, P. - WoOtTon, R. 2012: Adoption of telemedicine: from pilot stage to routine delivery. In: BMC Medical Informatics and Decision Making 12. 1. (1) 9 p.

183.ZHANG, X. - YU, P. - YAN, J. - SPIL T.A.M. 2015: Using diffusion of innovation theory to understand the factors impacting patient acceptance and use of consumer e-health innovations: a case study in a primary care clinic. - In: BMC Health Services Research 15. 1. (71) 15 p.

184.ZUNDEL, K. M. 1996: Telemedicine: history, applications, and impact on librarianship. - In: Bulletin of the Medical Library Association 84. 1. pp. 71-79.

\section{Felhasznált források}

[1]: https://www.ims.hu/site/ttekg_szakma (utolsó hozzáférés: 2017.06.18.)

[2]: https://www.random.org/integers/ (utolsó hozzáférés: 2017.06.18.)

[3]: https://fogalomtar.aeek.hu/index.php/Telemedicina (utolsó hozzáférés: 2017.06.18.)

[4]: http://www.ksh.hu/docs/hun/xstadat/xstadat_eves/i_wdsd008.html (utolsó hozzáférés: 2017.06.18.)

[5]: https://fogalomtar.aeek.hu/index.php/Interoperabilit\%C3\%A1s (utolsó hozzáférés: 2017.06.18.) 


\section{Köszönetnyilvánítás}

A disszertáció megírása és a kutatás során sok segítséget kaptam, amit ezúton szeretnék megköszönni az érintetteknek. Mindenekelőtt témavezetőmnek, Dr. Pál Viktornak, aki hosszú évek óta kíséri tudományos munkámat és lankadatlanul segítette azt hasznos tanácsaival, iránymutatásaival.

Köszönetet szeretnék mondani a Szegedi Tudományegyetem Gazdaság- és Társadalomföldrajz Tanszék vezetöjének, Dr. Kovács Zoltán Professzor Úrnak, aki támogatta a dolgozat megírását.

Szeretném megköszönni Dr. Uzzoli Annamáriának és Dr. Boros Lajosnak az észrevételeiket és hasznos tanácsaikat, amelyekkel elláttak a munkahelyi vita során.

A köszönetemet szeretném kifejezni mindazoknak az interjúpartnereknek (háziorvosoknak, szakorvosoknak, egészségügyi felsővezetőknek, informatikusoknak), akik értékes idejükböl áldoztak arra, hogy segítsék a munkámat, és ezzel hozzájárultak e disszertáció elkészültéhez.

Hálás vagyok azon egészségügyi szolgáltatók munkatársainak, akik kitöltötték és visszaküldték a számukra készített online kérdöívet.

Köszönet illeti azokat a családorvosokat is, akik vállalták a részükre kialakított kérdőív kitöltését. Ebben a tekintetben köszönetet szeretnék mondani az SZTE ÁOK Családorvosi Intézet munkatársainak, különösképpen Dr. Mester Lajosnak, az adatfelvétel kivitelezésében nyújtott segítségéért.

Továbbá szeretném megköszönni a demonstrátoroknak az interjúk transzkriptálásában nyújtott aktív tevékenységüket.

Végül, de nem utolsó sorban pedig hálás vagyok a Családomnak, akik mindvégig mellettem álltak és támogattak. 


\section{Mellékletek}

\section{Melléklet 1: Online kérdöiv}

1. Melyik típusú kapcsolatot tekinti Ön telemedicinának? (Kérem, jelölje a megfelelö kategóriát.)

○ Az orvos-orvos közötti távközlési és informatikai technológián alapuló kapcsolatot

○ Az orvos-beteg közötti távközlési és informatikai technológián alapuló kapcsolatot

$\circ$ Mindkettőt

○ Nem tudom

○ Nem kívánok válaszolni

Egyéb:

2. Tudomása szerint érintett volt-e az intézményük az elmúlt 5 év során valamilyen telemedicinával kapcsolatos egészségügyi szolgáltatásban? (Kérem, jelölje a megfelelö kategóriát.)

- Igen (Kérem, ugorjon a 4. kérdésre.)

- Nem (Kérem, ugorjon a 3. kérdésre.)

- Nem tudom (Kérem, ugorjon a 3. kérdésre.)

○ Nem kívánok válaszolni (Kérem, ugorjon a 3. kérdésre.)

3. Tudomása szerint az elkövetkezendő 1-2 éven belül tervezi-e intézményük, hogy részt vesz valamilyen telemedicinális szolgáltatásban? (Kérem, jelölje a megfelelö kategóriát.)

o Igen (Kérem, ugorjon a 10. kérdésre.)

- Nem (Kérem, ugorjon a 10. kérdésre.)

- Nem tudom (Kérem, ugorjon a 10. kérdésre.)

○ Nem kívánok válaszolni (Kérem, ugorjon a 10. kérdésre.)

4. Tudomása szerint mióta foglalkozik az intézményük telemedicinával? (Kérem, jelölje a megfelelö kategóriát.)

$\circ$ Kevesebb, mint 1 éve

○ 1-2 éve

○ 3-5 éve

○ Több, mint 5 éve

- Nem tudom

○ Nem kívánok válaszolni

5. Az Önök intézménye telemedicinális szolgáltatást ... (Kérem, jelölje a megfelelö kategóriát.)
○ biztosít (valakinek).
○ igényel (valakitől).
o biztosít és igényel is.
○ Nem tudom
○ Nem kívánok válaszolni

6. Ha intézményük telemedicinális szolgáltatást biztosit, akkor kinek? (Kérem, jelölje a megfelelö kategóriá(ka)t.)

○ Intézményük orvosai egymásnak

○ Más hazai intézmények orvosainak

○ Külföldi intézmények orvosainak

○ Pácienseknek

- Nem tudom

- Nem kívánok válaszolni

- Nem vonatkozik ránk

Egyéb: 
7. Ha intézményük telemedicinális szolgáltatást igényel, akkor kitől? (Kérem, jelölje a megfelelö kategóriá(ka)t.)

○ Intézményük orvosai egymástól

○ Más hazai intézmények orvosaitól

○ Külföldi intézmények orvosaitól

$\circ$ Nem tudom

○ Nem kívánok válaszolni

○ Nem vonatkozik ránk

Egyéb:

8. Milyen típusú telemedicinával foglalkozik intézményük? (Kérem, jelölje a megfelelö kategóriá(ka)t.)

○ Távdiagnosztika

○ Távfelügyelet

○ Táv-konzílium

○ Táv-manipuláció

$\circ$ Nem tudom

○ Nem kívánok válaszolni

Egyéb:

9. Mely szakterületeken alkalmazza intézményük a telemedicinát? (Kérem, jelölje a megfelelő kategóriá(ka)t.)
- Belgyógyászat
$\circ$ Dermatológia
○ Fogászat
○ Fül-orr-gégészet
- Gasztroenterológia
- Geriátria
○ Gyermekgyógyászat
- Kardiológia
○ Neurológia
- Onkológia
- Ortopédia
- Patológia
$\circ$ Pszichiátria
- Pulmonológia
- Radiológia (távleletezés)
- Reumatológia
- Sebészet
- Szemészet
○ Szülészet-nőgyógyászat
- Urológia
○ Nem tudom
○ Nem kívánok válaszolni
Egyéb:.

10. Ha bármilyen észrevétele, megjegyzése van a kérdésekkel és/vagy a kutatással kapcsolatban, kérjük, irja le néhány mondatban! 


\section{Melléklet 2: Szakorvosi interjúvázlat}

1. Manapság egyre gyakrabban téma a médiában a telemedicina és annak részterületei. Ön hogyan került kapcsolatba a telemedicinával? Mik a tapasztalatai erröl az ellátási formáról? Az eddigi ismeretei alapján sikeresnek tekinti-e a telemedicinát?

2. A szakfolyóiratok és az Egészségügyi Világszervezet szerint számos tényezö akadályozza a telemedicina megjelenését és széleskörü elterjedését az egészségügyi rendszerekben. Az Ön praxisában milyen tényezök gátolják/ták a telemedicina alkalmazását?

3. Az egészségügyi intézmények közötti adat- és információcserét megnehezíti az informatikai rendszerek heterogenitása. Meglátása szerint az intézményük informatikailag felkészült-e a telemedicina alkalmazására?

4. Az információs és kommunikációs technológiák fejlödésének köszönhetően a távoli, egészségügyileg kedvezötlen helyzetben lévö térségek is viszonylag könnyen bekapcsolódhatnak az ellátásba. Hogyan értékelné a telemedicina távolságcsökkentö hatását? Milyen hatása van a telemedicinának az egészségügyi ellátás elérhetőségére?

5. A telemedicinát egyre több intézményben és szakterületen alkalmazzák az egészségügyi ellátásban. Véleménye szerint a telemedicina milyen esetekben helyettesitheti a hagyományos ellátást, illetve milyen esetekben szolgálhat alternatívaként? Meglátása szerint melyek azok a szituációk, amelyekben nem alkalmazható? Ön érzékel minőségi változást a kétfajta ellátás között?

6. A távellátás az egészségügyi szakemberek és intézmények közötti együttmüködésen alapul. Meglátása szerint mitöl függ az, hogy valahol kialakul távellátás, valahol nem?

7. A telemedicinális szolgáltatásban távellátást nyújtó és fogadó felek lépnek interakcióba egymással. Milyen kapcsolatban van azokkal az egészségügyi szakemberekkel, akikkel távkonzultációt, távdiagnosztikát folytat? Hogyan irná le ezt a kapcsolatot? Feltételez-e ez a kapcsolat hierarchikus viszonyt?

8. Az Önök munkájában is kiemelt szerepe van a több éves szakmai tapasztalatnak. Meglátása szerint milyen mértékben jelenik meg a szakmai kompetencia, az implicit tudás a távkonzultációkban, távdiagnosztikában? Ön hogyan viszonyul ehhez? 
9. Az elözöekhez kapcsolódóan Önöknél hogyan müködik a döntéshozatal a távellátásban? Hol hozzák meg a (diagnosztikai, terápiás) döntést? Milyen metódus alapján?

10. A nemzetközi szakirodalom szerint a magasabb progresszivitási szintü egészségügyi intézmények meghatározó funkciót kapnak a telemedicinális hálózatok kialakitásában. Meglátása szerint milyen szerepet töltenek be hazánkban a klinikák, országos intézmények a távellátásban? Milyen kapcsolatban állnak ezekkel az intézményekkel?

11. Az egészségügyi ellátás mindig is az orvos és a beteg közötti bizalmi viszonyon alapult. Véleménye szerint mi jellemzi az orvos-beteg kapcsolatot a távellátásban? Van-e közvetlen kapcsolatban betegekkel a telemedicina során? Milyen a viszonya ezekkel a pácienseivel? Mennyire nyitottak a telemedicina iránt? Milyen problémák nehezitik a távellátás egyes formáinak igénybevételét a betegek szempontjából? Meglátása szerint milyen társadalmi csoportba tartozók veszik igénybe a távellátást és melyek szorulnak ki ebböl?

12. Manapság meglehetösen felkapott lett az internetes beteg kérdez, orvos válaszol rovatok. Ön regisztrálte valamilyen egészségportálra? Véleménye szerint milyen egészségügyi eredménnyel jár ezek használata? Meglátása szerint telemedicinának tekinthetö-e ez a szolgáltatás?

13. Az egészségügy számos területi egyenlötlenségi problémával küzd: az orvoshiánytól, az infrastrukturális ellátottság területi különbségein át az egészségi állapotban megbúvó egyenlötlenségekig. Véleménye szerint miként befolyásolja a telemedicina a meglévö egészségügyi egyenlötlenségeket?

14. Meglátása szerint hogyan befolyásolja az egészségügyi intézmény felszereltsége, eszközállománya a távellátás milyenségét?

15. Véleménye szerint milyen szerepet játszik a távellátásban a magasan kvalifikált egészségügyi szakemberek (specialisták) jelenléte? Hogyan befolyásolja annak az egészségügyi intézménynek a távellátásban betöltött szerepét, melynek munkatársai?

16. A szakirodalom szerint fontos szerepet töltenek be a távellátásban az orvosokat kiszolgáló egészségügyi személyzet. Meglátása szerint milyen mértékben válnak részévé a távellátásnak az egészségügyi asszisztensek (ápolók)? Milyen mértékben terheli öket felelösség e tekintetben?

17. A távellátás átalakítja, módositja a progressziv ellátási szintek szerepét. Véleménye szerint hogyan hat a telemedicina a szakorvosi ellátás igénybevételére? Ez milyen egészségügyi eredménnyel jár? 
18. Együttmüködik-e háziorvosokkal a telemedicinális ellátás során? Meglátása szerint a távellátás miként befolyásolja az alapellátás szerepkörét és minöségét?

19. Az eddigi tapasztalata alapján hogyan látja a telemedicina jövőjét? 


\section{Melléklet 3: Háziorvosi interjúvázlat}

1. Manapság egyre gyakrabban téma a médiában a telemedicina és annak részterületei. Ön hogyan került kapcsolatba a telemedicinával? Mik a tapasztalatai erröl az ellátási formáról? Az eddigi ismeretei alapján sikeresnek tekinti-e a telemedicinát?

2. A szakfolyóiratok és az Egészségügyi Világszervezet szerint számos tényezö akadályozza a telemedicina megjelenését és széleskörü elterjedését az egészségügyi rendszerekben. Az Ön praxisában milyen tényezök gátolják/ták a telemedicina alkalmazását?

3. Az információs és kommunikációs technológiák fejlödésének köszönhetően a távoli, egészségügyileg kedvezötlen helyzetben lévö térségek is viszonylag könnyen bekapcsolódhatnak az ellátásba. Hogyan értékelné a telemedicina távolságcsökkentö hatását? Milyen hatása van a telemedicinának az egészségügyi ellátás elérhetöségére?

4. A távellátás az egészségügyi szakemberek és intézmények közötti együttmüködésen alapul. Meglátása szerint mitöl függ az, hogy valahol kialakul távellátás, valahol nem?

5. A telemedicinának számos elönye is ismert. Milyen információval rendelkezik arról, hogy milyen egészségügyi hatása van a telemedicina alkalmazásának? Véleménye szerint hogyan hat a telemedicina a betegek egészségi állapotára?

6. Manapság egyre gyakrabban téma a telemedicinán belül is a távfelügyelet. Mi a véleménye az egészségügyi paramétereket mérö készülékekröl, mobil alkalmazásokról?

7. A telemedicinát egyre több szakterületen alkalmazzák az egészségügyi ellátásban. Véleménye szerint van-e lényeges különbség a hagyományos (fizikális jelenléten alapuló) ellátás és a távellátás között? Ha igen, miben látja?

8. Az egészségügyi ellátás mindig is az orvos és a beteg közötti bizalmi viszonyon alapult. Véleménye szerint mi jellemzi az orvos-beteg kapcsolatot a távellátásban? Van-e közvetlen kapcsolatban betegekkel a telemedicina során? Milyen a viszonya ezekkel a pácienseivel? Mennyire nyitottak a telemedicina iránt? Milyen problémák nehezítik a távellátás egyes formáinak igénybevételét a betegek szempontjából? Meglátása szerint milyen társadalmi csoportba tartozók veszik igénybe a távellátást és melyek szorulnak ki ebböl?

9. Manapság meglehetösen felkapott lett az internetes beteg kérdez, orvos válaszol rovatok. Ön regisztrált-e valamilyen egészségportálra? Véleménye szerint milyen egészségügyi eredménnyel jár ezek használata? Meglátása szerint telemedicinának tekinthetö-e ez a szolgáltatás? 
10. Az egészségügy számos területi egyenlötlenségi problémával küzd: az orvoshiánytól, az infrastrukturális ellátottság területi különbségein át az egészségi állapotban megbúvó egyenlötlenségekig. Véleménye szerint miként befolyásolja a telemedicina a meglévö egészségügyi egyenlötlenségeket?

11. Együttmüködik-e szakorvosokkal a telemedicinális ellátás során? Milyen kapcsolatban van ezekkel az egészségügyi szakemberekkel? Feltételez-e ez a kapcsolat hierarchikus viszonyt?

12. Meglátása szerint a távellátás miként befolyásolja az alapellátás szerepkörét és minöségét?

13. Az eddigi tapasztalata alapján hogyan látja a telemedicina jövőjét? 


\section{Melléklet 4: Egészségügyi felsövezetői interjúvázlat}

1. Mi a véleménye a telemedicináról, mint egészségügyi ellátási formáról? Meglátása szerint mi tartozik ennek tárgykörébe?

2. Mik az egészségpolitika elképzelései a telemedicinával kapcsolatban? Mire lehet számítani az elkövetkezö években?

3. Tervben van-e a telemedicina finanszírozása az egészségügyben? Ha igen, hogyan kivánják ezt megvalósitani? Ha nincs, akkor mi ennek az oka?

4. Meglátása szerint milyen tényezők akadályozzák a telemedicina alkalmazását az egészségügyben?

5. Mi a véleménye a telemedicina földrajzi távolságcsökkentő hatásáról? Miként befolyásolja az egészségügyi ellátás elérhetőségét?

6. Milyen információval rendelkezik arról, hogy milyen egészségügyi hatása van a telemedicina alkalmazásának?

7. Ön érintett volt-e valaha a telemedicina alkalmazásában/használatában, mint orvos, vagy mint magánszemély? Ha igen, hogyan?

8. Meglátása szerint hogyan változtatja meg a telemedicina a hagyományos orvos-beteg kapcsolatot?

9. Véleménye szerint van-e lényeges különbség a hagyományos (fizikális jelenléten alapuló) ellátás és a távellátás között? Ha igen, miben látja?

10. Véleménye szerint miként befolyásol(hat)ja a telemedicina a meglévő egészségügyi egyenlötlenségeket?

11. Milyen jövöbeli tervei(k) vannak a telemedicina tekintetében? Hogyan látja a telemedicina jövöjét hazánkban? 


\section{Melléklet 5: Informatikus interjúvázlat}

1. Ön hogyan került kapcsolatba a telemedicinával? Mi a véleménye erröl az ellátási formáról? Az eddigi ismeretei alapján sikeresnek tekinti-e a telemedicinát?

2. Milyen feladatot lát el (az intézményükben) a telemedicinával kapcsolatosan? Milyen telemedicinális projekten dolgozik/dolgozott az elmúlt években?

3. Meglátása szerint az intézményük informatikailag felkészült-e a telemedicina alkalmazására? Miben kellene változtatni? Véleménye szerint a felhasználók informatikailag mennyire felkészültek e technológiák használatára?

4. Mi a véleménye a telemedicina távolságcsökkentö hatásáról? Miként befolyásolja az egészségügyi ellátás elérhetöségét?

5. Meglátása szerint milyen tényezök akadályozzák a telemedicina alkalmazását az (intézményükben) egészségügyben?

6. Van-e tudomása arról, hogy mely orvosi szakterületek érintettek a telemedicinával az intézményükben/az egészségügyben?

7. Milyen információval rendelkezik arról, hogy milyen egészségügyi hatása van a telemedicina alkalmazásának?

8. Mi a véleménye az egészségügyi paramétereket mérö készülékekröl, mobil alkalmazásokról?

9. Van-e tudomása arról, hogy milyen telemedicinával kapcsolatos jövöbeli tervekkel, célokkal rendelkezik az intézményük, ami érinti az informatikai részlegüket is?

10. Mit gondol a telemedicina jövöjéröl? Véleménye szerint létrejöhet-e egy olyan virtuális közösség, amikor az egészségügyi ellátás alapvetően távellátáson alapul? Ön hogyan vizionálja ezt? 


\section{Melléklet 6: Családorvosi kérdöív}

1. Hallott-e már a telemedicináról?

$\square$ Igen (1) $\quad \square$ Nem (2) (Kérem, folytassa a 2. kérdéssel!)

1.1. Ha igen, milyen forrásból szerzett információt róla? (Több válasz is megjelölhetö!)

$\square$ Szakfolyóiratok, szakkönyvek (1)

$\square$ Szakmai konferenciák, képzések (2)

$\square$ Kollégák (3)

$\square$ Internet (4) $\square$ Tv, rádió, újság (5)

$\square$ Nem tudja (6)

$\square$ Nem válaszol (7)

$\square$ Egyéb (8)

(Több válasz is adható!)

2. Kérem, röviden fejtse ki, hogy Ön mit ért telemedicina alatt?

3. Alkalmazza-e jelenleg a telemedicinát a praxisában?

$\square$ Igen (1)

$\square$ Nem (2) (Kérem, folytassa a 3.2. kérdéssel!)

3.1. Ha igen, mióta alkalmazza ezt az ellátási formát? (Kérem, folytassa a 4. kérdéssel!)

éve

3.2. Ha nem, mi az oka annak, hogy nem használja a telemedicinát? (Több válasz is megjelölhető!) (Amennyiben a 3. kérdésre igennel válaszolt, akkor kérem, erre ne válaszoljon!)

$\square$ Nem ismeri (1)

$\square$ Költségesnek véli (2)

$\square$ Időigényesnek véli (3)

$\square$ Bonyolultnak tartja (4)

$\square$ Hiányolja a finanszírozását (5)

$\square$ Egyéb (11).

(Több válasz is adható!)

3.3. Ha jelenleg nem alkalmazza, az elkövetkező néhány éven belül tervezi-e alkalmazni a telemedicinát?

$\square \operatorname{Igen}(1)$

$\square \operatorname{Nem}(2)$

$\square$ Plusz feladatként tekint rá (6)

$\square$ Tart a másoktól való függéstől (pl. szakorvos) (7)

$\square$ Nem hiszi, hogy hasznos lenne (8)

$\square$ Nem tudja (9)

$\square$ Nem válaszol (10)

4. Mennyire tartja szükségesnek a telemedicina használatát az alapellátásban? (Kérem, értékelje válaszát 1-től 5-ig és karikázza be a megfelelő számot! (1= nem fontos, 5= nagyon fontos))

$\begin{array}{lllll}1 & 2 & 3 & 4 & 5\end{array}$

5. Volt-e olyan esete, hogy segítséget jelentett volna a telemedicina a munkájában, de nem használta?
$\square$ Igen (1)
$\square$ Nem (2) (Kérem, folytassa a 6. kérdéssel!)

5.1 Ha igen, hány alkalommal került ilyen szituációba?

$\square$ 1-2 alkalommal (1)

$\square$ Nem tudja (4)

$\square$ 3-5 alkalommal (2)

$\square$ Nem válaszol (5)

$\square$ Több mint 5 alkalommal (3) 
6. El tudja-e képzelni, hogy idősek is használják a telemedicinális eszközöket?

$$
\square \text { Igen (1) } \quad \square \operatorname{Nem}(2)
$$

7. Ön személy szerint mit várna el a telemedicinától az alapellátásban? (Kérem, jelölje, hogy az alábbiak közül melyeket tekinti lehetségesnek és melyeket nem!)

Betegek egészségi állapotának javulása (1)

Beteg compliance növekedése (2)

Betegbiztonság javulása (3)

Pontosabb, megbízhatóbb diagnózis (4)

Gyorsabb, hatékonyabb ellátás (5)

Távoli szakorvosi vélemény helyben, kisebb településeken is (6)

Betegek utazási idejének és költségének csökkenése (7)

Betegek várakozási idejének csökkenése (8)

Alapellátásban jelentkező orvoshiány mérséklése (9)

Családorvosok leterheltségének csökkenése (10)

Egyéb (11).

(Több válasz is adható!)

8. Véleménye szerint az alábbiak közül milyen betegségek esetén lenne célszerü a telemedicina használata? (Több válasz is megjelölhető!)

$\square$ Cukorbetegség (1)

$\square$ Lipid anyagcsere betegségek (2)

$\square$ Magasvérnyomás (3)

$\square$ Ischaemiás szívbetegségek (4)

$\square$ Egyéb (9)

(Több válasz is adható!)
Igen (1) Nem (2)

$\begin{array}{ll}\square & \square \\ \square & \square \\ \square & \square \\ \square & \square \\ \square & \square \\ \square & \square \\ \square & \square \\ \square & \square \\ \square & \square \\ \square & \square\end{array}$

9. Mely szakterületeken tudná elképzelni a telemedicinával kapcsolatos együttmüködést a szakorvosokkal? (Több válasz is megjelölhető!)

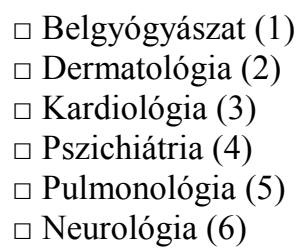

$\square$ Cerebrovascularis betegségek (5)

$\square$ Légúti megbetegedések (6)

$\square$ Nem tudja (7)

$\square$ Nem válaszol (8) 
14. Mely járás(ok)ban müködik jelenleg az Ön praxisa? (Több válasz is adható!)

15. Szeretné-e, hogy beépüljön a továbbképzések anyagába a telemedicináról szóló információ?

$$
\square \text { Igen (1) } \quad \square \text { Nem (2) }
$$

16. Ha bármilyen észrevétele, megjegyzése van a kérdésekkel és/vagy a kutatással kapcsolatban, kérem, írja le néhány mondatban! 


\begin{tabular}{|c|c|c|c|c|c|c|c|c|}
\hline \multirow[b]{3}{*}{ Betegségek } & \multicolumn{8}{|c|}{ Az orvoshoz fordulás és a terápiás javaslat megjelenése a válaszokban (\%) } \\
\hline & \multicolumn{2}{|c|}{ Orvoshoz fordulás } & \multicolumn{2}{|c|}{ Terápiás javaslat } & \multirow[b]{2}{*}{ Mindkettő } & \multirow[b]{2}{*}{ Egyik sem } & \multirow{2}{*}{$\begin{array}{l}\text { Csak orvoshoz } \\
\text { fordulás }\end{array}$} & \multirow{2}{*}{$\begin{array}{l}\text { Csak terápiás } \\
\text { javaslat }\end{array}$} \\
\hline & Igen & $\mathrm{Nem}$ & Igen & $\mathrm{Nem}$ & & & & \\
\hline Bör & 71,11 & 28,89 & 46,98 & 53,02 & 31,43 & 13,33 & 39,68 & 15,56 \\
\hline Emésztöszervi & 65,29 & 34,71 & 48,80 & 51,20 & 30,93 & 16,84 & 34,36 & 17,87 \\
\hline Mozgásszervi & 79,33 & 20,67 & 48,02 & 51,98 & 41,64 & 14,29 & 37,69 & 6,38 \\
\hline Nögyógyászati & 74,86 & 25,14 & 20,92 & 79,08 & 16,88 & 21,10 & 57,98 & 4,04 \\
\hline Sziv-érrendszeri & 80,14 & 19,86 & 29,45 & 70,55 & 24,66 & 15,07 & 55,48 & 4,79 \\
\hline Neurológiai & 82,83 & 17,17 & 30,81 & 69,19 & 26,77 & 13,13 & 56,06 & 4,04 \\
\hline Urológiai & 76,44 & 23,56 & 15,71 & 84,29 & 10,47 & 18,32 & 65,97 & 5,24 \\
\hline Endokrin & 71,97 & 28,03 & 12,12 & 87,88 & 9,09 & 25,00 & 62,88 & 3,03 \\
\hline Fül-orr-gégészeti & 78,63 & 21,37 & 40,46 & 59,54 & 25,95 & 6,87 & 52,67 & 14,50 \\
\hline Egyéb & 71,18 & 28,82 & 25,00 & 75,00 & 17,36 & 21,18 & 53,82 & 7,64 \\
\hline Összes típus & 74,55 & 25,45 & 32,62 & 67,38 & 24,28 & 17,11 & 50,27 & 8,34 \\
\hline
\end{tabular}

